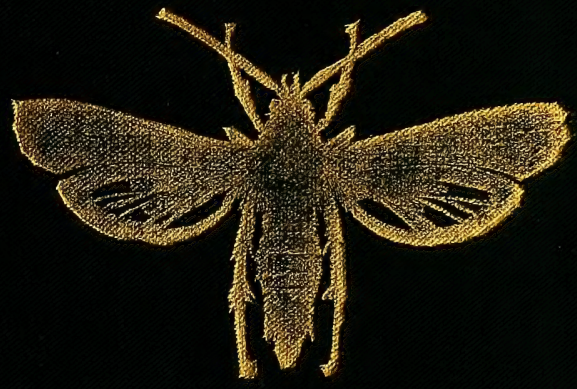


LIBRARY OF CONGRESS. Ting?

Shelf. 2039

UNITED STATES OF AMERICA. 






\section{Insects and Insecticides.}




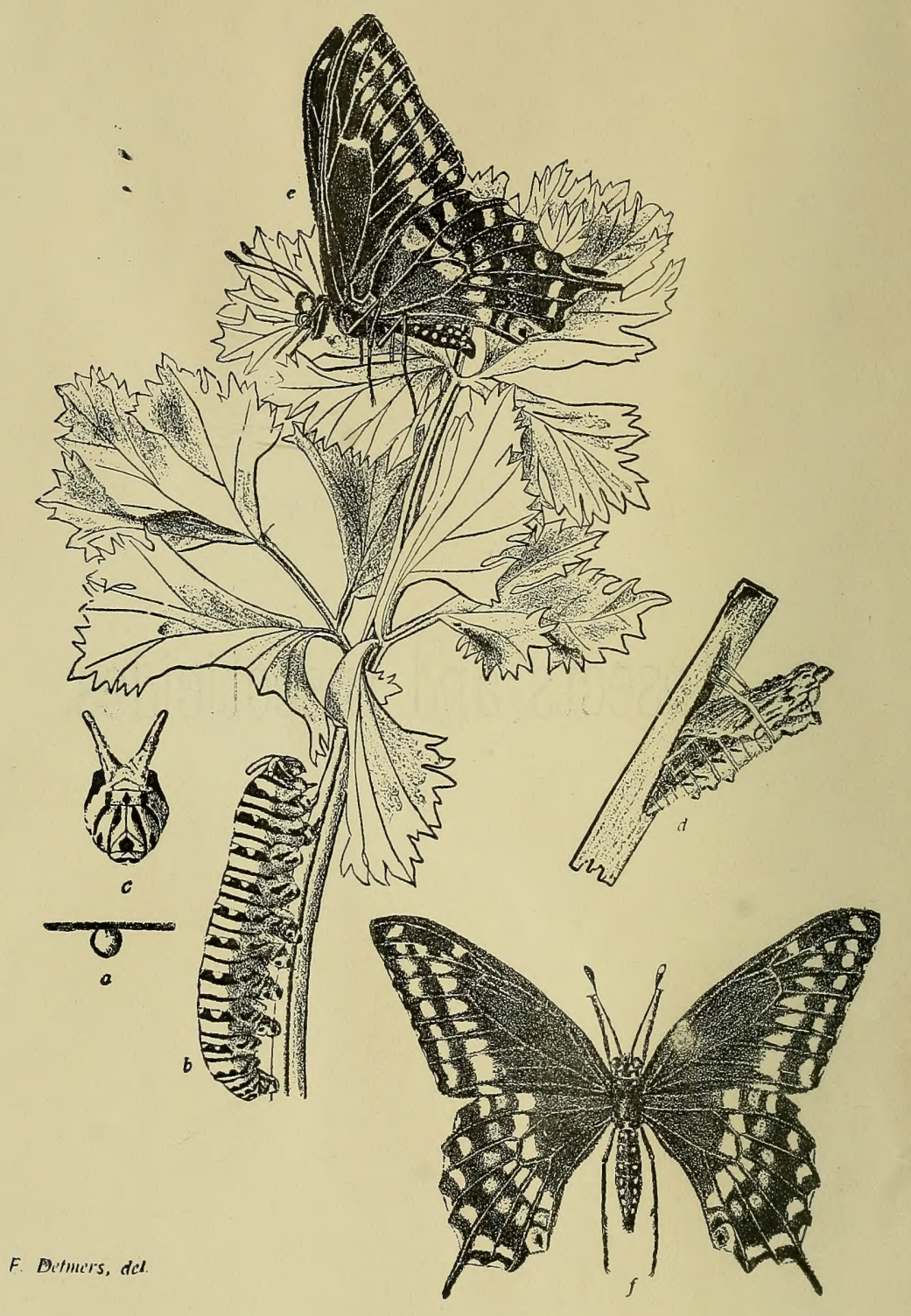

Plate 1.-Transformations of the Celery Caterpillar. 


\title{
INSECTS
}

\section{- AND- \\ INSECTICIDES.}

\section{A PRACTICAL MANUAL}

\author{
CONCERNING
}

Noxious Insects and the Methods of Preventing their Injuries.

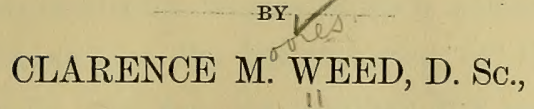

Professor of Entomology and Zoology, New Hampshire College of Agriculture and Mechanic Arts; recently Entomologist, Ohio Agricultural Experiment Station; Fellow of the Royal Microscopical Society of England, and of the American Association for the Advancement of Science; Member of the Society for the Promotion of Agricultural Science, Societe' Entomologique de France, Cambridge Entomological Club, Association of Economic

Entomologists, ete.

WITH MANY ILLUSTRATIONS. 


\section{SB931 w39}

Copyright, 1891, by Clarence M. Weed

Presb of Gazette Printing House Columbus, Оніо. 


\section{PREFACE.}

This little volume has been prepared for the purpose of furnishing the farmer, the fruit-grower, the floriculturist, and the house-keeper with a concise account of the more important injurious insects with which they have to contend, together with a summary of the latest knowledge concerning the best methods of preventing or counteracting the injuries of these pests. In its preparation free use has been made of the information scattered through the literature of economic entomology; and, as a rule, it has been found impracticable to give to each author credit for first working ont the life-histories of the various species. In one way or another the contributions of nearly every American economic entomologist have been drawn upon; but especial mention should be made of the help obtained from the publications of Dr. C. V. Riley, United States entomologist, whose remarkable investigations during the last quarter of a century have placed him foremost among the world's economic entomologists. A large proportion of the insect life-histories summarized in the following pages were first worked out by him, or under his direction. Mention should also be made of the 
aid derived from the writings of Messrs. Forbes, Cook, Comstock, Lintner, Garman, Howard, Harvey, Bruner, Webster, Saunders, Osborn, Gillette, Fletcher and many others.

The illustrations of this volume have also been gleaned from various sources. Many of them were printed from electrotypes obtained by duplicating a series of cuts belonging to the Ohio Agricultural Experiment Station, thanks to the permission of Director C. E. Thorne; and the rest have been gotten from several sources. The original authors to whom each should be credited is indicated in the following lists :

After Riley:-Plate IV, and Figs. 1, 2, 4, 5, 9, 10,13 (p. 40), 14, 16-20, 22, 23, 26, 36, 38, 39,41-43, $47-52,53$ (reduced), 54-67, 68 (reduced), 69, 70, 72, $87,88,90,91,92 a, 98,99-106,113,114,116,123$, 125, 126, 127 (reduced), 130, 131, 133-135, 138, 140144; after Lugger, Fig. 6 ; after Harris, Figs. 15, 48 ; after Harris and Saunders, Fig. 129 ; reduced from Osborn, Figs. 137, 139; after Garman, Figs. 30, 33, 34, 37, 111 (reduced), 112 (reduced), 122 (reduced); after after Bruner, Fig. 73; after Glover, Fig. 35; after Miss Ormerod, Fig. 136 ; after Harvey, Fig. 21 ; after Comstock, Figs. 28, 89, 109. Fig. 7 is from the Field Force Pump Company, and Figs. 11, 27 and 28 have 
been obtained from the publishers of Farm and Fireside. The following have been drawn under the author's supervision, by Miss Freda Detmers: Plates

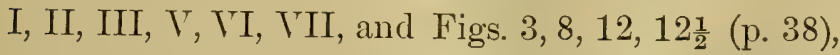
$24,25,31,40,44-47,74-80,82,83$ (p. 157), 85, 86, $92 b, 93-97,107,108,115,120,121,124,129,132$.

All the figures are natural size unless otherwise stated, and wherever a straight line occurs beside a magnified drawing, it represents the length of the specimen figured.

A small edition of the first three parts of this work was published in connection with the Report of the Columbus, (Ohio) Horticultural Society for 1890.

I have attempted to make the discussions of lifehistories and remedies as plain and simple as possible, omitting, so far as practicable, all technical terms, and have included only such details as are necessary to a practical understanding of the subjects treated of. In several cases where the scientific designations of species have been lately changed, the old form has been retained, because articles concerning the insect can thus more easily be found in the literature of economic entomology.

$$
\text { C. M. W. }
$$

Hanoter, New Hampshire, April, 1891. 


\section{CONTENTS.}

PAGE.

Introduction

9

PART I.

Insects Affecting the Larger Fruits.

Apple 29) Pear ......................... 65

Plum

58 Cherry ....................... 72

Peach 77

\section{PART II.}

Insects Affecting Small Fruits.

Strawberry .................... 85 Raspberry and Blackberry 103

Currants and Gooseberries.. 96 Grape ....................... 108

\section{PART III.}

Insects Affecting Shade Trees, Ornamental Plants, and FLOWERS.

Shade Trees

131 Rose 154

Flowers 158

\section{PART IV.}

Insects Affecting Vegetables.

Tomato....................... 165 Bean and Pea............... 185

Potato........................ 168 Cabbage...................... 188

Celery........................ 175 Onion....................... 203

Squash and Cucumber..... 176 Asparagus................... 204

Rhubarb.................................................. 183

\section{PART V.}

Insects Affecting Cereal and Forage Crops.

Indian Corn.................. 209 Clover....................... 234

Wheat....................... 220 Grass........................ 242

\section{PART VI.}

Insect Pests of Domestic Animals and the Household.

Insects Affecting Domestic Animals ........................... 257

Insect Pests of the Household................................ 267 


\section{EXPLANATION OF PLATES.}

PLATE I.

Transformations of the Celery Caterpillar. Frontispiece.

$a$, egg.

$b$, full-grown larva.

$c$, front view of head of same, with scent organs extended. $d$, chrysalis.

$e$, butterfly at rest.

$f$, butterfly with wings spread. $a$ and $c$ are slightly magnified.

\section{PLATE II.}

\section{A Group of Aegerian Moths (Twice Natural Size).}

1. Peach Tree-borer, Sannina exitiosa, male.

2. Peach Tree-borer, Sannina exitiosa, female.

3. Pear Tree-borer, Aegeria pyri,male.
4. Imported Currant-borer, Aegeria tipuliformis, male.

5. Maple Tree-borer, Aegeria acerni. female.

6. Aegeria lustrans.

7. Plum Tree-borer, Aegeria pictipes.

PLATE III.

A Group of Leaf-hoppers. (Much Magnified.)

1. Typhlocyba abliqua.

2. Typhlocyba tricincta.

3. Typhlocyba basilaris.
4. Typhlocyba comes.

5. Typhlocyba vitis.

6. Typhlocyba vulnerata.

7. Typhlocyba vitifex.

PLATE IV.

The Cecropia Emperor-moth. Platysamia cecropia.

PLATE V.

The Tomato-worm Sphinx. Phlegethontius celeus.

PLATE VI.

The Striped Harvest Spider. Liobunum vittatum.

PLATE VII.

The SCRew-worm. Compsomyia macellaria. 



\section{INSECTS AND INSECTICIDES}

INTRODUCTION.

The agriculturist has continually to contend with two classes of organisms that injure his crops. The first of these are the noxious insects, and the second, the parasitic fungi. These foes annually destroy many million dollars worth of produce in the United States, a large portion of which might be saved by the timely application of the various methods of prevention and remedy that are now known. The rages which follow are devoted to a consideration of the more important of the first named of these enemies-the noxious insects-and to the methods of preventing their injuries.

Insects are distinguished from related animals by having three pairs of feet, fitted for locomotion, attached to a body divided into three principal parts -head, thorax and abdomen. A majority of them are also characterized by undergoing during their development a series of well-marked changes, or transformations. Such insects exist in four distinct stages, namely: (1) the egg; (2) the larva or caterpillar; (3) the pupa or chrysalis; and (4) the adult or imago. As an example of these changes we may take the Celery Caterpillar, the transformations of which are illustrated at Plate I. The adult butterfly, a handsome, black creature, with yellow and blue 
markings on its wings (Plate I, e, $f$,), deposits an egg on the under side of the celery leaf. This egg $(a)$ is a small, light yellow object, nearly spherical, though slightly flattened where it is attached to the leaf. A week or so after it has been laid there hatches from it a small caterpillar or 'worm,' less than onetenth of an inch long, black, with two transverse white bands-one across the middle of the body and the other at the posterior extremity-and having the back roughened with minute, black, projecting points. This little caterpillar feeds upon the celery leaf, and within a few days so increases in size that it becomes necessary to shed its skin, or moult. For this purpose the skin splits along the back and the caterpillar walks out, clothed in a new skin that had been formed beneath the old one. The color markings are somewhat different on this new covering. The caterpillar continues feeding and growing for several weeks, casting its skin at occasional intervals, and changing considerably in color and markings. When full grown it is of the form and size indicated at $b$ on the plate, the general color being pale green, with a series of transverse bands of black and yellow markings. When irritated it thrusts out, from a slit just back of the head, a pair of peculiar yellow Yshaped organs, that emit a disagreeable odor. These organs are represented at $b$ on the caterpillar, and at $c$ is shown a front view of the head, with them extended. They doubtless serve as a protection from various enemies. 
The full grown caterpillar becomes restless, and leaving the plant, seeks some sheltered situation in which to pupate. "It first spins," says Dr. Harris, " a little web or tuft of silk against the surface whereon it is resting, and entangles the hooks of its hindmost feet in it, so as to fix them securely to the spot; it then proceeds to make a loop, or girth, of many silken threads, bent into the form of the letter $U$, the ends of which are fastened to the surface on-which it rests on each side of the middle of its body; and under this, when finished, it passes its head and gradually works the loop over its back, so as to support the body and prevent it from falling dornwards. Within twenty-four hours after it has taken its station, the caterpillar casts off its caterpillar skin, and becomes a chrysalis, or pupa (Plate $I, d$ ) of a pale green, ochre-yellow, or ash-gray color, with two short ear-like projections above the head, just below which, on the back, is a little prominence like a pug nose. The chrysalis hangs in the same way as the caterpillar, and remains in this state from nine to fifteen days, according to the temperature. When this period is terminated, the skin of the chrysalis bursts open, and the butterfly issues from it, clings to the empty shell till its cramped and drooping wings have extended to their full dimensions, and have become dried, upon which it flies away in pursuit of companions and food."

Besides celery this caterpillar feeds upon parsley, carrots, and related plants. The butterfly is known to entomologists as Papilio asterias. 
Insects which undegro such a marked series of changes as those above described are said to have complete transformations, to distinguish them from

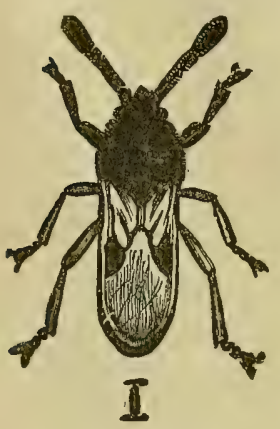

Fig. 1. Chinch Bug. Mragnified.

those which do not undergo so marked, a series of changes-those with incomplete transformations. In one stage of existence-that of the chrysalis or pupa-insects of the first class take no food and are unable to move about. With these, also, the young or larva differs greatly in form and appearance from the adult. Thus, caterpillars are very unlike the butterflies and moths into which they develop, and larval honey bees differ greatly from the adults; but with the insects of the second class this marked difference does not exist. The Chinch Bug furnishes a good illustration of these transformations. The adult bug (Fig. 1) deposits eggs (Fig. 2. $a, b$ ) about the roots of $\mathrm{g}$ rass and grain. From these $\mathrm{h}$ at $\mathrm{ch}$ young bugs $(c)$ that do not differ in general Fig. 2. Chinch Bug: $a, b$, eggs; $c, e, f$, $g$, young form from the
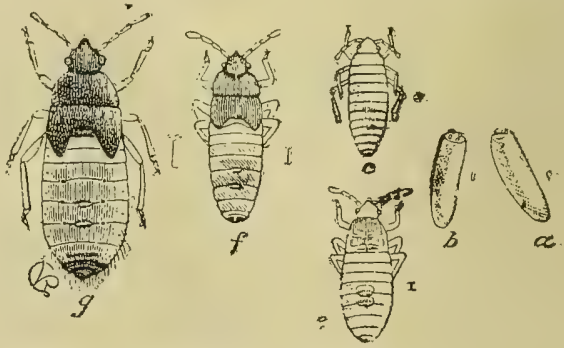
adults. They suck the sap from various plants of 
the grass family, gradually increasing in size, and moulting at intervals. In a few weeks they become nearly full grown, but instead of changing to a quiet chrysalis state, they simply moult again and continue feeding as before. In these early stages, which correspond to the larva and chrysalis, they are called nymphs. The older nymphs $(g)$ are nearly as large as the full grown bugs, differing mainly in the absence of wings. In about a week they again moult and come forth as adult bugs. Grasshoppers, crickets, and all true bugs, undergo these incomplete transformations.

\section{BITING AND SUCKING INSECTS.}

Insects take their food in two ways: some insects bite, others suck. The former, of which the Colorado Potato Beetle is an example, are provided with jaws by which they can gnaw the surface of the foodplant. The latter have, instead, a pointed, tube-like beak which they can insert into the tissues of their host-plant, and suck out the sap.

On account of this difference in feeding habits some insects can be destroyed by coating their foodplants with poison-the Colorado Potato Beetle for example - while others, like the plant-lice or Chinch Bug, must be treated with some insecticide that kills by contact.

NATURAL ENEMIES OF INJURIOUS INSECTS.

Injurious insects have many natural enemies to contend with. Among the larger animals they are 
preyed upon by 'the forl of the air and thie fish of the sea'; frogs lick them up with their viscid tongues, and toads are continually sending them in search of the 'mystic jewel' within their bodies, while snakes, lizards, moles, skunks, and a host of other animals are their constant enemies. But more destructive than any or all of these, are the foes of their own class-the predaceous and parasitic insects.

Predaceous insects are those which attack other insects from the outside, devouring them bodily, or

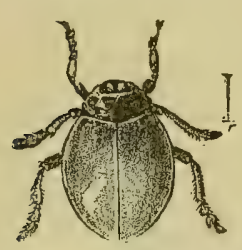

Fig, 3. Lady Beetle. MIagnified. sucking out their life blood. The handsome little lady-beetles (Fig. 3), the two-winged robber-flies, or the four-minged dragon-flies furnish good examples of this class. So, also, do the black ground beetles, found everywhere under sticks and stones. Some of the largest of these are called caterpillar hunters, because they feed upon canker-worms, armyworms, cut-worms, and various other insect pests. One of these ground beetles is shown at Fig. 4, the larva being representer at the left, and the beetle at the right. Other predaceous insects live in ponds, lakes and rivers, devouring mosquitoes and related creatures, while still others
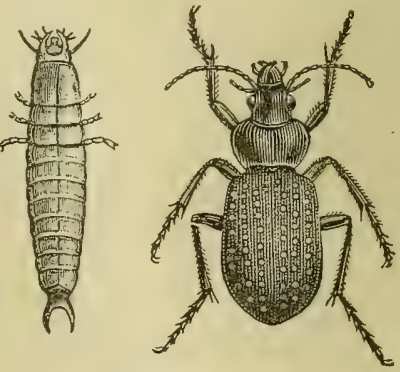

Fig. 4. Ground Beetle. 
burrow through the earth and devour the insects found therein.

Parasitic insects differ from their predaceous cousins, in that they develop within the bodies of their victims and thus destroy them. These, also, are exceedingly numerous, both in individuals and species. A good illustration of the habits of this class is found in the small, four-winged, black fly (shown natural size and magnified at the right in Fig. 5), that destroys the common Grape Caterpillar, an insect closely related to the familiar Tomato Worm or Tobacco Worm. This fly deposits a number of eggs beneath the skin of the caterpillar, and these eggs soon hatch into minute worms or maggots that absorb the body juices of the worm and develop at his expense. After a few weeks these maggots become full grown, and burrow their way out through the skin of their hapless and helpless host. They then. spin their white, silken cocoons (Fig. 5) upon his back. Within these cocoons Fig. 5. Caterpillar with Cocoons of Parasite. they change to the pupa or chrysalis state. About tro weeks later they again change, and the legless, little maggots find themselves transformed into neat and pretty black flies, with four wings and six legs, like the one which a few weeks before deposited in the caterpillar the eggs from which they dereloped. 
But these parasites are not always so successful as this, for they frequently furnish a striking illustration of Dean Swift's oft-quoted couplet:

The little fleas that do us tease

Have other fleas that bite 'em,

And these in turn have other fleas,

And so on ad infinitum.

These parasites are frequently subject to the at-

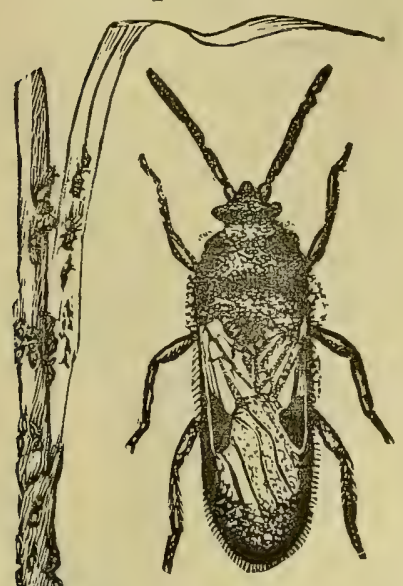
tack of a still smaller parasite which destroys them as they destroyed their host. In such cases the first mentioned species is called the primary parasite, and the other a secondary parasite.

There are also foes of another kind from which injurious insects often suffer. These are the germs of contagious diseases, of a bacterial or fungous nature. The Imported Cabbage Worm, for example, is frequently attacked by a bacterial disease-a sort of in-

Fig. 6. Chinch Bugs affected by Entomophora.

sect cholera-that destroys it in great numbers. Similar diseases affect the Army Worm, the various cut-worms, and many other insects. Diseases of a sowewhat different nature, due to certain fungi other than bacteria, also attack many insects. For instance, the Chinch Bug is frequently destroyed in 
great numbers by a fungus that derelops on the surface of the bug as a dense, white covering. This disease is illustrated at Fig. 6: a number of dead bugs are shown on a wheat stalk on the left, while a single bug, much magnified, covered with the fungus, is represented at the right. This fungus belongs to a genus of plants called by botanists Entomophora.

\section{THE PRINCIPAL INSECTICIDES.}

Insecticides, or the substances used for destroying insects, may be broadly divided into two classes: (1) internal poisons, or those which take effect by being eaten along with the ordinary food of the insect; and (2), external irritants, or those which act from the outside-closing the breathing pores, or causing death by irritation of the skin. Besides these, however, various other substances are used in preventing insect attack-keeping the pests away because of offensive odors, or acting simply as mechanical barriers.

The most important insecticides are the poisons. Of these the most popular are the various combinations of arsenic, known as Paris green, London pur. ple, slug-shot, and a large number of patent insecticides sold under various names.

Paris Green is a chemical combination of arsenic and copper, called arsenite of copper. It contains about fifty-five or sixty per cent. of arsenic, and retails at about thirty cents per pound. It is practically insoluble in water, and may be applied either 
dry or wet. In the former case it should be well mixed with some fine powder as a diluent: plaster, air-slaked lime, flour, road-dust, and finely-sifted wood ashes, all answer the purpose fairly well, though lime or plaster are usually preferåble. The proportion of poison to diluent varies greatly with different users-one part poison to fifty, and even one hundred, of diluent, will usually be effective, if the mixing be thoroughly done. In the wet mixture, for fruit and shade trees, use one pound poison to 250 gallons of water, and keep well-stirred. The chief objection to Paris green is that it is so heavy that it settles quickly to the bottom of the vessel-very much more quickly than London purple. It is also more expensive.

London Purple is a by-product obtained in the manufacture of aniline dyes. It generally contains nearly the same percentage of arsenic as Paris green, which, however, is often in a more soluble form, and consequently it is more liable to injure foliage than Paris green. It is a finer porvder than the green, and. hence remains in suspension in water much longer. It is also cheaper, retailing at about fifteen cents per pound. It may be used in the same way - as a powder or in. water suspension-and the proportions given above answer very well for it. But it should never be applied to plants having a foliage easily injured by these arsenites, like the peach or plum, Paris green being preferable for this purpose.

White Arsenic is sometimes recommended as an insecticide, but, fortunately, is rarely used. It is much 
more dangerous to have around than either of the above highly colored substances; and unless applied as soon as it is mixed with water is very liable to burn the foliage.

The principal substances used for killing insects, by contact, are the following:

Hellebore is a powder made of the roots of a plant called white hellebore (Veratrum album). It is a vegetable poison, but much less dangerous than the mineral, arsenical poisons, and kills both by contact and by being eaten. It may be applied as a dry powder or in water, an ounce to three gallons. It retails at about twenty-five cents per pound, and is especially excellent in destroying the Imported ('urrant Worm.

Pyrethrum is an insecticide of recent introduction, made from the powdered flowers of plants of the genus Pyrethrum. There are three principal brands upon the market, known as Persian insect powder, Dalmatian insect powder, and Buhach-the latter being a California product. The greatest obstacle to the use of Pyrethrum has been the difficulty of obtaining the pure, fresh article. After long exposure to air it seems to lose much of its insecticidal value. Hence dealers should purchase a fresh supply each season, and should keep it in air-tight vessels. Pyrethrum is used mainly as a dry powder or in water (one ounce to three gallons); but may also be used in the form of a tea, or a decoction, a fume, or an alcoholic extract diluted. For use as a dry porrder it 
may advantageously be diluted with six or eight parts of flour. It is especially excellent for clearing rooms of flies and mosquitoes, and for killing the common cabbage worms. It is practically harmless to man and the higher animals.

Kerosene Emulsion is prepared by adding two parts of kerosene to one part of a solution made by dissolving half a pound of hard soap in one gallon of boiling water, and churning the mixture through a force pump with a rather small nozzle until the whole forms a creamy mass, which will thicken into a jelly-like substance on cooling. The soap solution should be hot when the kerosene is added, but of course must not be near a fire. The emulsion thus made is to be diluted, before using, with nine parts cold water. This substance destroys a large number of insects, such as the Chinch Bug, Cabbage Worm, and White Grub; and is a comparatively cheap and effective insecticide.

Besides its use as an emulsion, kerosene alone is frequently used for various pests. It is especially valuable in destroying vermin on domestic animals, and in hen houses.

Carbolic Acid, especially in its crude state, is valuable for various insecticidal purposes. An excellent wash for preventing the injuries of several tree borers is made by mixing one quart soft soap, or about a pound of hard soap, with two gallons water, heating to boiling, and then adding a pint of crude carbolic acid. Carbolic acid soaps are largely used for destroying vermin on domestic animals. 
Tobacco is a very valuable insecticide for use against vermin on domestic animals, and green-house pests. It may be used in the form of a decoction, a smoke, or dry. The refuse stems and powders from the cigar factories are very valuable as insecticides and fertilizers, and frequently, in the middle restern states, they may be obtained for little or nothing.

Bisulphide of Carbon is a volatile substance used for destroying grain insects, ants, the Grape Phylloxera, and other insects which may be reached by a vapor. It is inflammable and should never be used in the vicinity of a fire.

Benzine is another volatile substance used for much the same purposes as the last.

Gasoline may also be mentioned in the same connection.

Coal Tar has been largely used ir the west for destroying Rocky Mountain Locusts, being placed on flat pans, on which the insects jump and are caught. It is also employed to prevent the migrations of the Chinch Bug. A shallow V-shaped channel is made with the corner of a hoe along the borders of the field to be protected, and tar poured in. So long as the tar does not dry out, the immature Chinch Bugs cannot cross it.

\section{APPLYING INSECTICIDES.}

The methods of applying insecticides, of course, vary according to the nature of the substance, and the insect against which it is to be used. The 
powders, such as Paris green, London purple, hellebore, etc., may be applied either dry or in water. When applied dry they should be dusted on the plants with a bellows or "powder gun," so that they will be distributed evenly. When applied in water mixture the best effects are obtained by using a force pump and spray nozzle. There are a great many patterns of these spraying machines upon the mar-

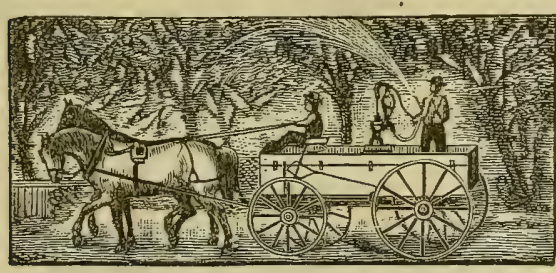

Fig. 7 . Spraying an Orchard.

ket, nearly all of which do effective work. The principal requisites of a good machine are that it be durable, easily worked, not too expensive, throw a fine spray, stir the liquid automatically, and that the reservoir holding the liquid be large enough for the purpose intended. One of these machines in operation in an orchard is represented at Fig. 7. Spraying pumps can be obtained of a number of firms who manufacture various styles of them.

\section{COLLECTING AND PRESERVING INSECTS.}

The apparatus for collecting insects is neither elaborate nor expensive. One of the first essentials is a collecting net, which is used for catching butterflies, moths, bees, flies, wasps, and in fact, nearly all flying insects. To make it, obtain àn iron wire about $\frac{1}{5}$ of an inch in diameter, and bend it into a circular 
ring 12 or 13 inches in diameter, leaving the ends projecting at right angles to the circle, and relding: them together so as to form a spur three or four inches long. Fasten this spur into the end of a broomstick, or any other convenient handle three or four feet long. Then sew over this wire circle a strip of strong muslin, an inch or two wide, and to this sew a bag of mosquito netting, sriss muslin, or some similar fabric, about three feet deep. For collecting insects in ponds, a shallower net is needed, and the cloth used should be of stronger material.

After the insects are caught some way of killing: them quickly, and without injury, is needed. For this purpose most entomologists use what is called the cyanide bottle. To make this, obtain almost any wide-mouthed glass bottle with a tight fitting cork; place on the bottom two or three lumps of cyanide of potassium; the size of a hickory nut, cover these with plaster of Paris, and, finally, add sufficient water to moisten the plaster and make it set. After it is hard pour off the surplus water if there is any, and let the bottle become thoroughly dry before inserting the cork. This cyanide of potassium is poisonous, and of course must be handled carefully. If desired, the bottles may be prepared at drug stores, at small cost. After the plaster is set there is practically no danger, unless the fumes of the bottle be directly inhaled, for which there is no excuse. Keep' the bottle closed except when putting in an insect. The cyanide fumes, rising through the porous plaster, will kill it almost instantly. This cyanide bottle 
is to be used especially for moths, butterflies, bees, wasps and similar insects, but should not be used for worms and caterpillars, which are more successfully killed and preserved in alcohol.

A pair of straight, medium sized, forceps are useful in collecting small insects. A supply of ordinary commercial alcohol, and of various sizes, (2, 3 and 4 drachm) of short, homeopathic vials will be necessary if soft-bodied caterpillars, spiders, thousandlegged worms, etc., are collected. Empty morphine bottles are very convenient. An ordinary game bag is an excellent thing to carry the bottles, forceps and other 'traps' in, while out collecting:

For rearing insects, to study their transformations and habits, breeding cages of various kinds are needed. Almost any box may be used for this purpose, covering it in part with gauze, and placing on the bottom an inch or two of moist earth, to prevent the drying of the atmosphere. Ordinary jelly tumblers are very useful for rearing small leaf-eating caterpillars, and "bell glasses" or glass shades are quite handy. The cages should be examined daily, the food frequently renewed and the conditions which the insect would have in its natural habitat, should be supplied as far as possible.

PRESERVING THE SPECIMENS.

The first requisite for preserving insects, is a supply of entomological pins, which are longer, and usually more slender than ordinary pins, answering. 
the purpose much better. What is known as the Klæger pin is the best made. It can be purchased of dealers in natural history supplies. These pins vary in size, according to number. No. 2, is used only for very small insects, while No. 5, is large enough for any of our species. For the majority of specimens of moderate size, No. 4 may be used. A supply of sheet-cork is also needed. This costs about fifty cents a dozen sheets, and may also be obtained of natural history supply dealers.

Butterflies, moths, and some other insects require, for their proper preservation, what is called a 'setting-board,' one of which is shown in Fig. 8 It consists simply of two thin strips of pine board, twelve or sixteen inches long, nailed to end pieces, with a space varying from $\frac{1}{4}$ to $\frac{3}{4}$-inch between the long strips : a piece of thin cork is fastened

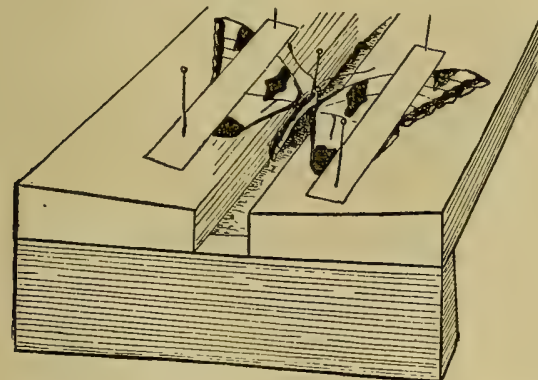

Fig. 8 Setting Board,

to the under side of the strips so as to cover this space. The pin on which the butterfly is fastened is pushed through the cork until the side pieces are level with the base of the wings. The wings are then brought forward until the posterior borders of the front ones are at right angles to the body, and they are then fastened in place by pieces of card-board 
held down with pins, as shown in the illustration. The insect should be left thus fastened until dry, so that the wings will remain in the position indicated. This usually requires from ten to fourteen days.

Some sort of boxes or cases in which to keep the specimens are of course necessary. The simplest and cheapest receptacle consists of empty cigar boxes, lined on the bottom with sheet cork. Tight wooden boxes of almost any kind will also answer the purpose. Shallow drawers with the bottoms lined with cork are excellent.

The specimens must frequently be examined to see that museum pests-insects which live on dead animal tissues of all kinds-do not destroy them. When these are found, bake the specimens in an oven for an hour, at a temperature of $140^{\circ}$ Fahrenheit.

Moths, butterflies, bees, wasps; and a large number of similar insects should be pinned through the center of the thorax, or middle division of the body, the pin being pushed through until about one-third of its length remains above the insect. Beetles, however, should be pinned through the right wing cover, and the true bugs through the triangular piece at the base of the wings, called the scutellum.

Any one desiring to learn about the classification of insects will find the Introduction to Entomology, by Professor J. H. Comstock, Ithaca, New York, extremely valuable. Professor Packard's books "Entomology for Beginners," and "Guide to the Study of Insects," which can be obtained through bookdealers, will also prove helpful. 


\section{PART I.}

INSECTS

AFFECTING THE LARGER FRUITS. 


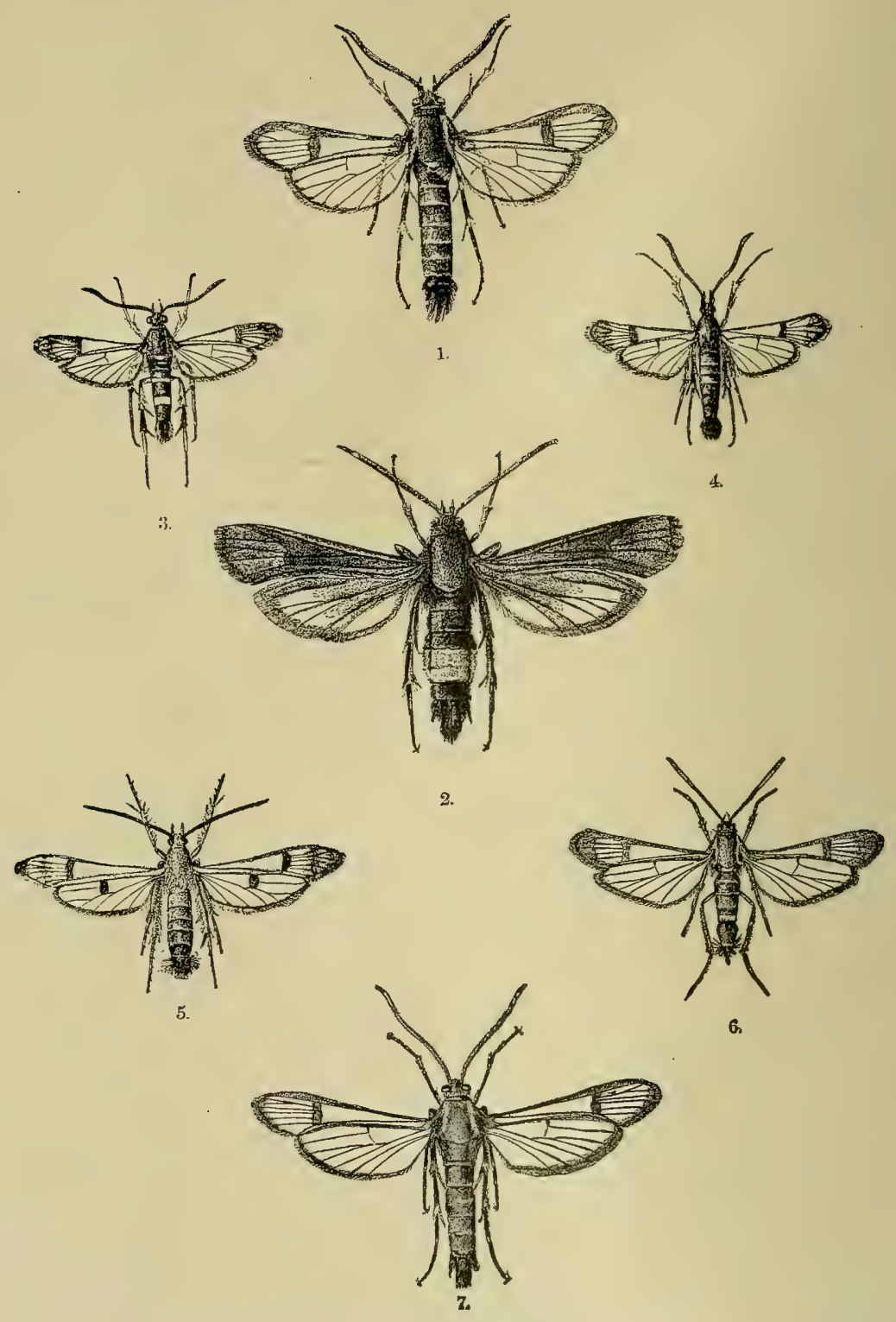

PLATE II.-A GRoup of Aegerian Moths. (MAgnified.) 


\section{INSECTS AFFECTING THE APPLE.}

\section{INJURING THE TRUNK.}

\section{The Round-headed Apple-tree Borer.}

\section{Saperda candida.}

The three later stages of this insect are shown at Fig. 9. The beetle (c) is easily recognized by the brown color of its body, and the two conspicuous, longitudinal, whitish stripes along its back. It appears early in summer, and deposits its eggs on the tree-trunks, in or under the bark, within a few inches of the ground, frequently placing them just above the soil surface, or even below it where the ground is cracked open so that the beetle can descend without difficulty. The insect makes a slit-like opening in the bark, into which the egg is pushed. A ferr days later the egg hatches into a larva or grub, which gnaws its way into the inner bark or sap-wood, where it continues to feed throughout the season. As winter approaches it frequently burroms downward below the surface of the ground, and rests there until spring, when it again works upward and gnaws the inner bark and sapwood as before. It rests again the following winter, and in spring gnaws its way deeper into the body of the trunk, cutting cylindrical channels in every direction. Late in summer it 
bores upwards and outwards to the bark, lining a cavity at the end of its burrow with dust-like castings, and there rests until spring, when it changes to the dormant chrysalis state $(b)$. The adult beetle emerges from the chrysalis about a fortnight later,
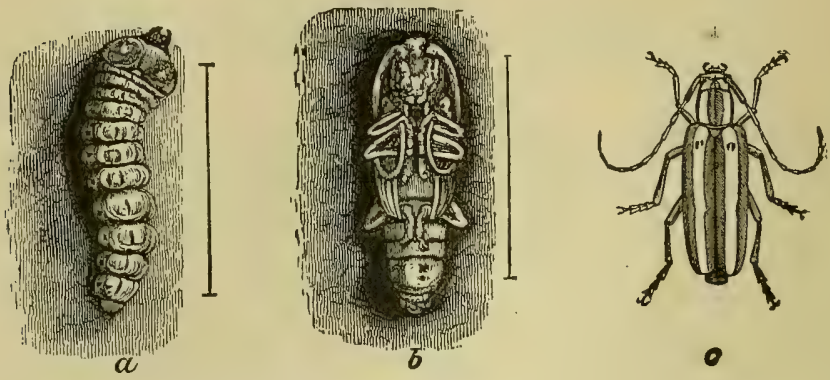

Fig. 9. Round-Headed Apple-tree Borer: $a$, larva; $b$, pupa; $c$, beetle.

eats a hole through the bark with its strong jaws, and comes forth to continue the propagation of the species. Thus three years are required for the development of the insect.

The place where the larva enters may frequently be detected, especially in young trees, by the sawdustlike castings that are pushed out. The eggs also may often be seen, and are easily destroyed by pressing on the bark surrounding them with a knife-blade or some similar instrument. The presence of the larva is shown later by the discoloration of the bark where it.is at work.

The full grown grub, or larva, of the Roundheaded Borer, is illustrated at $a$, Fig. 9. It is about. 
an inch long, wholly without feet, whitish, with a chestnut-brown head and black jaws. The pupa or chrysalis $(b)$ is lighter colored than the larva, and has numerous small spines on its back.

Remedies.-The injuries of this insect may be prevented by applying late in May, or early in June, and again about three weeks later, a sirong solution of soft soap, to which has been added a little crude carbolic acid. This mixture may be conveniently made by mixing one quart of soft soap, or about a pound of hard soap, with two gallons of water, heating to boiling, and then adding a pint of crude carbolic acid. The solution should be thoroughly applied (a scrub brush is excellent for the purpose) to the trunk and larger branches of the tree. If the bark of the trees is especially rough, it should be scraped before the wash is applied; and the soil should be smoothed down about the base of the trunk, so that there will be no cracks for the insects to enter to deposit their eggs. Of course the object of this application is to prevent the laying of the eggs from which the grubs hatch. As an additional precaution it is well to examine the trees during the late summer and early autumn months for eggs and young grubs, which are readily detected, and can be easily destroyed with a knife. In this way one man can go over an orchard of five hundred or more young trees in a day. 


\section{The Flat-headed Apple-tree Borer.}

Chrysobothris femorata.

This insect is very different, both in its adult and larval states, from the one just discussed. The adult beetle, instead of being cylindrical in form and brown in color, is flattened and greenish-black. It appears, however, at about the same season as the other, and the life histories of the two species are in general much alike, the principal difference being that the present species requires less time to develop, and attacks the tree higher up, being found all the way up the trunk, and frequently in the larger branches.

The front end of the larva, which is illustrated at

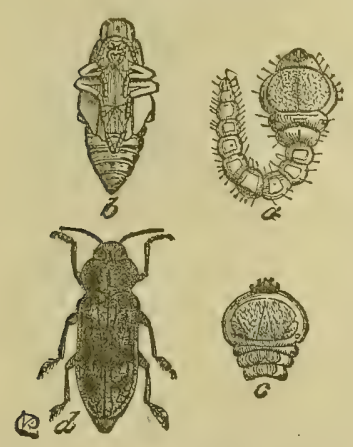

Fig. 10, $a$, is enlarged and flattened while the rest of the body is much narrower, and taper's slightly towards the posterior extremity. It is of a pale yellow color and has no feet. The pupa (b) is at first whitish, but becomes darker as the beetle develops. As noted above, the adult beetle $(d)$ is of Fig. 10. Flat-header Borer-" -a shining, greenish-black color,

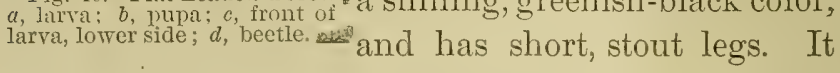
may often be seen basking in the sunshine in summer, on the sides of trees and logs. 
The eggs of this insect are deposited early in summer in the crevices, and under the scales of the bark, being fastened in place by a glutinous substance. In a few days the larva hatches and bores through the bark to the sapwood, in which it cuts broad, flat channels, and sometimes completely girdles the tree. As it develops it bores farther into the solid wood, and when fully grown again approaches the surface. When ready to become a pupa it gnaws partially through the bark, and then casts its last larval skin. About a fortnight later the pupa changes to a beetle which gnaws its way through the bark, and thus completes the cycle of development.

Remedies.-The directions given above for the Round-headed Borer are also applicable to this insect.

\section{INJURING THE BRANCHES.}

\section{The 0yster-shell Bark-louse.}

Mytilaspis pomorum.

A piece of bark covered with the scales of this insect is represented in Fig. 11. If one of these scales

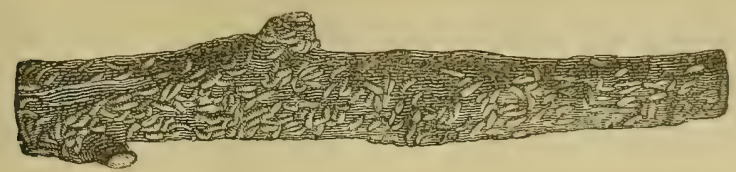

Fig. 11. Oyster-shell Bark-louse.

be raised early in spring there will be found beneath it a mass of yellowish or whitish eggs, which hatch 
about the middle of May into small lice, that appear as mere specks to the naked eye. These move about over the bark a few days, when they fix themselves upon it, inserting their tiny beaks far enough to reach the sap. Here they continue to increase in size, and by the end of the season have secreted scaly coverings like those shown in the illustration.

Remedies.-During the winter and early spring as many of the scales should be scraped off the trunk and larger branches as possible. On large trees this may be done by first scraping with some instrument like a hoe, and then thoroughly scrubbing with a scrub-brush or broom, dipped in a solution made by adding one part of crude carbolic acid to seven parts of a solution made by dissolving one quart of soft soap, or one-fourth of a pound of hard soap, in two quarts of boiling water. The bark of young trees is so tender that they must be scraped carefully, if at all. A scrub-brush is the best thing to use for applying the soap mixture, as the bristles remove many scales which a cloth would slide over. Then in May or June, soon after the young lice have hatched, the trees should be sprayed with kerosene emulsion. The emulsion must be thoroughly mixed, with none of the kerosene floating separately, or it is liable to injure the foliage. When the lice are young they are very readily destroyed by this substance. 


\section{The Woolly Aphis.}

\section{Schizoneura lanigera.}

There are frequently found on the limbs and trunks of young apple trees, masses of a white, woolly substance, similar to that occurring on the limbs of maple trees infested by the Maple Bark-louse. If one of these masses be examined there is found beneath it one or more small, yellowish plant-lice. This is the insect that has for a long time been popularly known as the Woolly Aphis. There are two forms of the insect, one attacking the roots, the presence of which may be easily detected by the knotty appearance of the infested rootlets, and one attacking the limbs and trunk. Like other aphides, these insects multiply rapidly during the summer months, by giving birth to living young. Most of these summer forms are wingless, but occasionally winged ones are found. They all injure the tree by sucking out its sap through their tiny beaks. They are especially liable to infest young trees, or those which are unhealthy. The woolly matter which they secrete as a covering serves to protect them from the damp earth, in their subterranean home on the roots, and probably is a partial protection from enemies above ground. It is not a complete protection, however, as they are preyed upon by a small, parasitic fly and by lady-bird beetles and their larvæ. 
Remedies.-Where these insects are upon the roots of trees they may be destroyed by applying scalding water, or kerosene emulsion. Refuse tobacco powder dug in about the roots will also destroy them. Where they are upon parts of the tree above ground, they may be destroyed by spraying with kerosene emulsion.

\section{The Buffalo Tree-hopper.}

\section{Ceresa bubalus.}

One sometimes finds the twigs of young apple trees exhibiting a peculiar, scarred appearance like that represented at $c$, Fig. 12. These are due to the egg punctures of the above named insect.

The Buffalo Tree-hopper is a small greenish or yellowish insect, about one-third of an inch long,
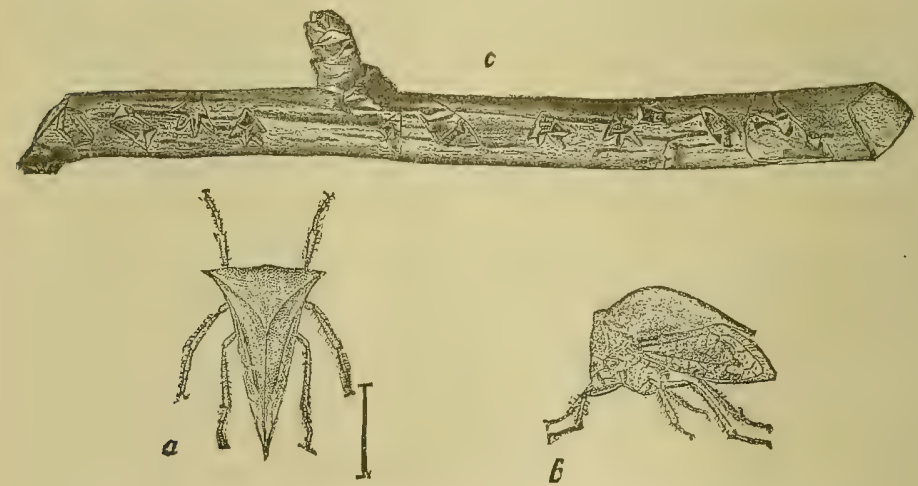

Fig. 12. Buffalo Tree-hopper: $a$, back view ; $b$, side view, both slightly magnified; $c$, apple twig shoxving egg punctures.

which is generally rather common during the late summer and early autumn months. A fair idea of 
its form, which has been compared to that of a beechnut, may be obtained from $a$ and $b$, Fig 12 . Its mouth consists of a sharp beak, which it inserts into the bark and sucks the sap. The eggs are laid in the upper part of the twigs of apple, pear, maple and various other fruit and shade trees, mostly during the late summer or early autumn months. They hatch the following May into small, active, greenish hoppers, somewhat like the adults in appearance, which insert their tiny beaks in the tender bark and suck out the sap. They become full-grown about midsummer, and feed, in both the young and adult states, on a great variety of plants.

This insect is said to have certain parasitic enemies that destroy its eggs. This is probably the reason that it seldom becomes seriously injurious.

Remedies.-It is always more difficult to prevent the injuries of an insect that feeds upon a large variety of plants, both wild and cultivated, than one which is confined for food to the single crop injured. As a rule it is also more difficult to fight those insects which get their food by sucking, than those which bite. The Buffalo Tree-hopper combines both of these characteristics, so that from the nature of the case we may expect it to be a difficult insect to overcome. Probably the most satisfactory method of destroying the pests will be to spray the trees just after the eggs hatch, with kerosene emulsion, made as directed in the Introduction. In those cases where the trees are infested by bark-lice, as well as 
the present pest, the same spraying may be made to kill both. By destroying the progeny of the eggs in this way, the crop of egg-laying specimens will be reduced, but it will not necessarily prevent the hoppers which develop in neighboring localities from invading the orchard to deposit eggs. When possible infested twigs should be cut out and burned.

\section{INJURING THE LEAVES.}

\section{The Apple Aphis.}

Aphis mali.

During the spring and early summer, one often finds the leaves and tender twigs of apple covered

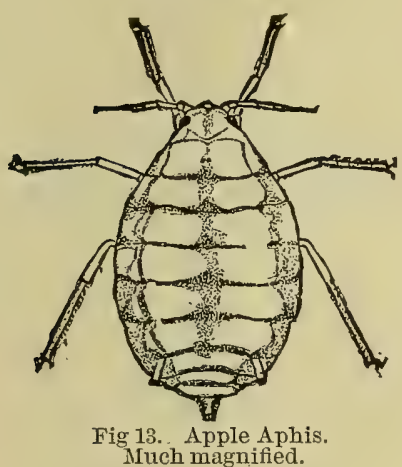

with small green lice or aphides. These are the Apple Aphis. They injure the trees by sucking the s a p through their tiny beaks. So far as we now know it, the life-history of these insects is as follows: The lice hatch from eggs in spring as soon as the leaf-buds begin to expand, and increase with marvelous rapidity, so that almost as fast as the leaves develop there are colonies of the plant-lice to occupy them. They continue breeding on apple until July, when they largely leave the 
trees, and migrate-we know not where, but probably to some amnual plant that is succulent in midsummer. Here, apparently, they continue breeding until autumn, when they return to apple, and the winged females may be found establishing colonies of the wingless, egg-laying form upon the leaves. The males are apparently developed on the same plant that the winged females are. The small, oval eggs are now laid on the twigs and buds, and the cycle for the year is complete.

Remedies.-These lice have various natural enemies that destroy them-especially the lady-bird beetles-but it is often necessary to spray infested trees with kerosene emulsion, or a strong tobacco decoction to get rid of them. The latter may be made by soaking refuse tobacco stems in hot water, and then draining the liquid off.

\section{The Canker Worm.}

Anisopteryx pometaria.

Apple orchards are occasionally infested in spring by a looping caterpillar, or "measuring worm," that feeds upon the parenchyma of the leaf, leaving the net work of veins, so that the foliage looks brown and scorched. These are canker worms, of which, according to Dr. Riley's observations, we have two distinct species. But both are similar in habits and injuries, and for the present purpose only one will be discussed. This is called the Fall Canker Worm. 
If, during the winter, or early spring months, one examines the branches of apple trees, in orchards where this insect has been at work, he will find compact masses of a hundred or more small, cylindrical eggs like that shown at $e$, Fig. 13. About the time
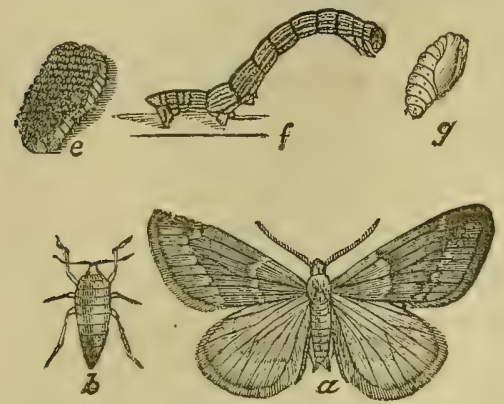

Fis. 13. Canker Worm: $e$, eggs; $f$, Iarva ; $g$, pupa ; $a$, male moth; $b$, female moth. the leaves begin to come out, these eggs hatch into small, looping caterpillars that feed upon the fo.liage. They continue feeding and growing for several weeks, when they become full grown, and look like $f$, Fig 13. They are about an inch long, quite slender, and vary from a greenish-yellow to a dark brown color. The Canker Worm then either crawls down the tree to the ground, or lets itself down, spider-like, on a silken thread: There it burrows into the soil three or four inches, where it spins a silken cocoon, within which it changes to the pupa, or chrysalis state $(g)$, remaining in this condition until autumn, when it emerges as a moth.

The two sexes of these Canker Worm moths differ greatly. The male (a), has large well developed wings, while the female $(b)$, is wingless. The latter is of an ashy gray color. When she emerges from 
the chrysalis state she crawls to the base of the tree, and ascends the trunk some distance. Here the male finds her, and after mating, she begins the deposition of eggs. These are placed on the twigs or branches of the tree.

The other Canker Worm (Anisopteryx vernata) is similar to this in habits, but most of the moths appear in the spring, rather than autumn. Hence it is commonly called the Spring Canker Worm.

Besides apple, these insects feed upon elm, cherry, plum and various other fruit and shade trees.

Remedies.-There are rarious natural enemies that prey upon these Canker Worms: these include both birds; and predaceous or parasitic insects. The simplest artificial remedy is to spray the trees soon after the worms hatch, with Paris green or London purple-a pound to 200 gallons of water. Or the ascent of the egg-laying moths may be prevented by applying tar, or printers ink, or some such substance, about the base of the tree-putting it on a band of paper if there is fear of injuring the tree by applying it directly to the bark. There are also various collars of metal or glass that are manufactured to place around the tree, and prevent the moths going up. But spraying is simpler and more effectual than any of these. 


\title{
The Apple-tree Tent Caterpillar.
}

\author{
Clisiocampa americana.
}

One often finds in May or June, on the limbs of apple and wild cherry trees, compact silken nests, or tents, containing a considerable number of handsome caterpillars. These are the insects which have been

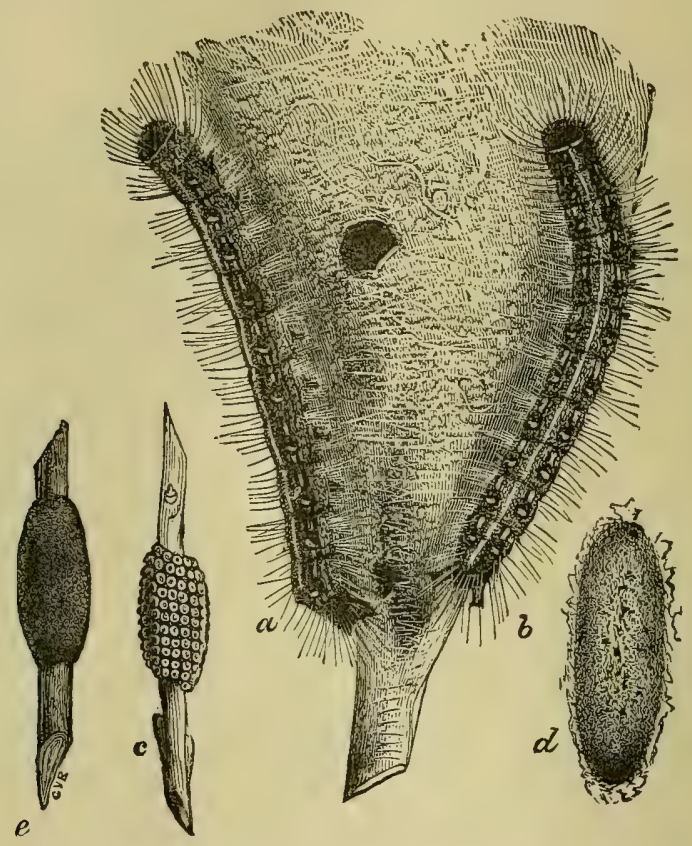

Fig. 14. Tent Caterpillar: $a, b$, larva ; $c$, eggs, with covering removed; $d$, cocoon; $e$, eggs, with covering on.

known for many years as Tent Caterpillars. The eggs are deposited during July, in compact masses of 
two or three hundred each, upon the twigs, as shown at c, Fig. 14. After they are laid the parent moth covers them with a viscid liquid, which dries into a sort of varnish that completely coats them, as represented at $e$. The insect remains in this egg state from July until the following spring; when the little caterpillars emerge from the eggs, and begin feeding upon the tender foliage of the buds about them. In a few days they begin to make a silken tent, utilizing generally, for this purpose, a fork of the branch. As time goes on the nest is enlarged. The caterpillars retire to the tent at night, and during cold and wet weather, and when not feeding. They have regular times for their meals, leaving and returning to the nest in processions. They become full grown in about six weeks, being extremely voracious during the latter part of their development. They are then nearly two inches long, with a hairy body, ornamented with a distinct white stripe along the middle of the back, on each side of which are numerous short, yellow, longitudinal lines, rather irregularly arranged. The sides are partially covered with paler lines, spotted and streaked with blue, while the lower surface of the body is black. The full grown caterpillar is represented at $a$ and $b$, Fig. 14 .

Most of the caterpillars leave the tree where their nest is, as fast as they become full grown, and crawl about in search of a suitable shelter to pupate in. Having found this-beneath a board, or in the cracks of a fence-they spin an oval, silken cocoon, 
(d), yellow when completed, within which they change to the pupa or chrysalis state. In two or three weeks another change takes place, and from the cocoons come forth

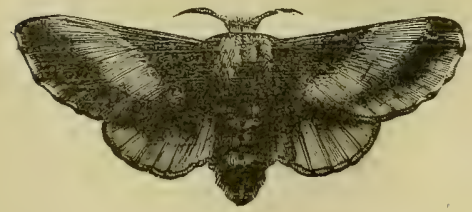

Fig. 15. Moth of Tent Caterpillar. reddish-brown moths, of the size and form represented at Fig. 15. These moths pair and in a short time deposit the clusters of e g g s, after which they soon die. Thus there is but one brood each season.

Remedies.-It is usually easy to destroy the nests of this insect, either by cutting and burning the infested branch, or using a torch made by saturating a piece of cloth, tied to the end of a stick, with kerosene. In either case the operation should be performed early in the morning, before the insects have left the tent, or in the evening after they have returned. Spraying with Paris green is also an effectual remedy. There are certain parasites preying upon this insect that aid greatly in keeping it in check.

\section{The Lesser Apple Leaf-roller.}

\section{Teras minuta.}

This is a greenish-yellow, slightly hairy worm, about half an inch long, affecting the young leaves of the terminal twigs, with which the insect forms a protective case. It is especially injurious in nurseries and young orchards. 
This species is remarkable in that two of the three broods of moths which appear during the year are of a bright orange color, while those of the third brood are reddish-gray. It is an example of what naturalists call dimorphism.

The eggs are laid in the spring on the unfolding leaves of apple, cranberry, whortle berry and possi-

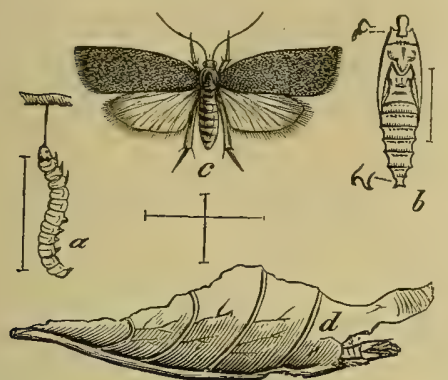

Fig. 16. Lesser Leaf-roller: $a$, larva : $b$, pupa; $c$, moth; $d$, rolled-leaf.

bly other plants, the larvæ soon hatching to devour the tender foliage, some of which they roll into a protective covering. Here they continue feeding for about a month, when they pupate within the folded leaves, and a week or so later emerge as small, orange-yellow moths. These moths lay eggs for another brood of larvæ, the imagos from which appear in August, being also of the same orange color. These in turn lay eggs for a third brood of worms, which develop during September, and emerge during October as glistening reddish-gray moths, which pass the winter in rubbish heaps, fence corners and similar places of concealment, and deposit eggs on the unfolding leares of the various food plants of the larræ the following spring. Thus this remarkable cycle of insect life is completed. 
Remedies.-In fruiting orehards that are regularly sprayed with the arsenites to prevent Codling Moth injury, this insect is not likely to prove troublesome. But in nurseries and young orchards. it is frequently quite destructive. Spraying with the arsenites is probably as promising as any general remedy in these cases, though the experience of nurserymen has shown that on young nursery stock the insect may advantageously be destroyed by hiring boys to crush the larvæ within their cases.

\section{The Yellow-necked Apple-tree Caterpillar.}

\section{Datana ministra.}

During the latter part of summer the orchardist occasionally finds one or more limbs of his apple trees entirely denuded of their foliage by a troop of large, striped caterpillars, like the one shomn at Fig. $17, a$. These are the progeny of a set of eggs $(c, d)$

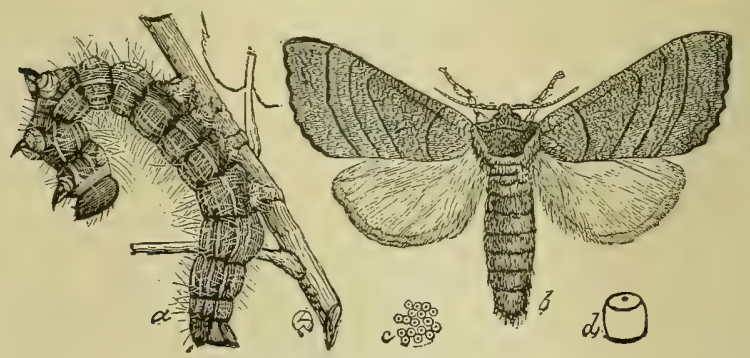

Fig. 17. Yellow-necked Caterpillar: $a$, larva; $b$, moth ; $c$, eggs ;

laid during June or July by a large moth $(b)$ with a chestnut-brown thorax, and light brown wings, striped. 
with brown of a darker shade. The very young larvæ feed only upon the parenchyma of the leaf, leaving a network of bare veins, but they soon grow large enough to eat veins and all. They are gregarious, feeding together and denuding the limb as they go. When at rest or alarmed, they assume the peculiar position shown in the figure. They become full-grown in about six weeks, when they descend to the ground and burrow into the soil three or four inches, where they change to the pupa state. They remain in this condition until the following summer, when they emerge again as moths. Consequently, there is but one brood a year.

Remedies.-Birds and various insect enemies prey upon this caterpillar to such an extent that it rarely becomes injurious. When it does, however, it may easily be destroyed by spraying the infested trees with Paris green in water mixture, or by cutting and burning the twigs on which the larvæ are feeding.

\section{The Leaf-crumpler.}

Phycis indigenella.

One often finds during the winter months upon the twigs of various fruit trees, masses of dry bromn leaves, that, when pulled apart, are seen to surround a long, tubular, horn-like case. If one of these cases be carefully cut open it will be found to contain a brownish worm or caterpillar, about half an inch long. This insect is the Leaf-crumpler, and it often becomes one of the most injurious of orchard pests. 
The adult insect is a small, grayish moth (Fig. 18, $d$,) that appears during June or July, and deposits eggs on the various trees that serve as food plants for the larvæ. These include the apple, quince and possibly the peach, as well as both the wild and cultivated varieties of the cherry, plum, and crab-apple.

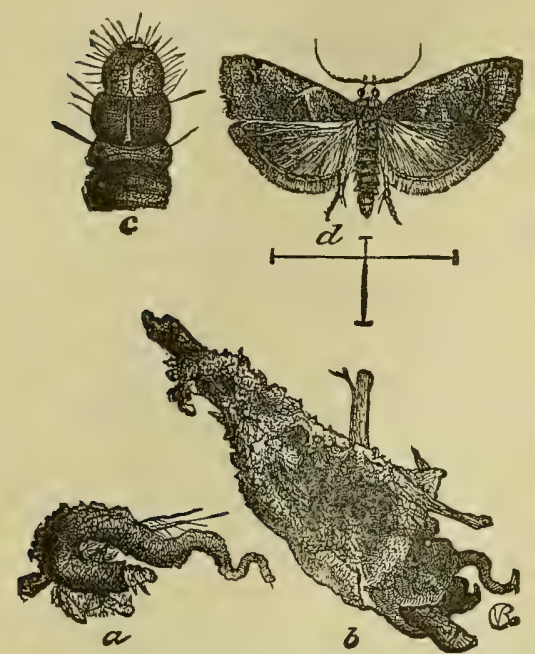

Fig, 18. Leaf-crumpler: $a$, larval case; $b$, larval case with dead leaves; $c$, front part of larva; $\boldsymbol{d}$, moth, magnified.

From these eggs there soon hatch small brown is h wo r m s that construct tubular, silken cases $(a)$ within which they remain concealed wh en not eating. As they grow larger they draw a bout the openings of their abodes many partially eaten leaves, so that by autumn there is quite a bunch surrounding each case (b). At the approach of cold weather the cases are attached to the twigs by means of silken threads, the larva frequently gnawing away the tender bark to insure a firm hold ; and thus the winter is passed. As soon in spring as the leaves begin to appear, the larvæ attack them, frequently eating out the flower buds as well. They continue feeding. 
and growing until sometime in June, when they become pupæ, pupating within the cases. About a fortnight later the moths emerge, and thus the lifecycle is completed.

There are several species of parasites that prey upon the Leaf-crumpler which greatly assist in keeping it in check.

Remedies.-In young orchards the larval cases are easily picked off during the winter. They may be burned, or what is probably better, carried to a considerable distance from their food plants and left on the ground, thus allowing the parasites to develop and escape. The insect is also liable to destruction by spraying with Paris green, or London purple, and may easily be held in check in this way. Where orchards are sprayed for the Codling Moth, the Leafcrumplers present will also largely be destroyed.

\section{The Apple Leaf-skeletonizer.}

\section{Pempelia hammondi.}

This is a brownish or greenish larva, one-half inch long, with short, scattered hairs upon its body, which spins a web upon the upper surface of the leaf, and eats the parenchyma, giving the foliage a scorched appearance. It is frequently very destructive to apples, especially to young trees, either in the orchard or nursery.

The life history of this insect may be briefly summarized as follows: The small purplish moths (Fig. $19, d$, ) having two light bands upon the front wings, 
and expanding scarcely half an inch, lay their eggs,

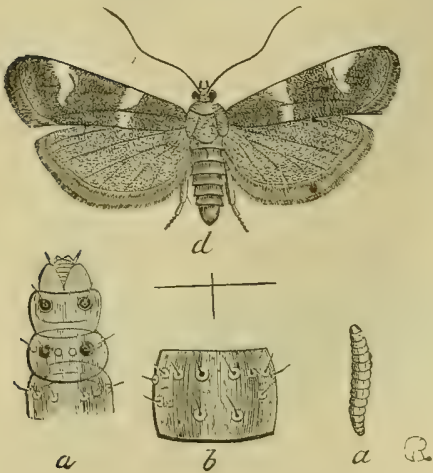

Fig. 19. Leaf-skeletonizer: $a$, larva; $b$ part of back, magnified to show markings; $c$, head and front part of larva, magnified; $d$, moth, magnifled. probably, on the leaves or tender twigs of the apple, late in spring, or early in summer. The larve soon hatch and begin to eat the parenchyma of the leaves, and as they grow older they spin a slight protective silken web. on the upper surface of the leaf, beneath which they continue their destructive work. When full grown (a) they vary from an olive, or pale green color to brown, are about half an inch long, and have four black shining tubercles on the back, just behind the head. About midsummer these larve pupate in slight cocoons, formed usually on the leaf, and two weeks later the moths emerge. Eggs are laid by these for the second brood of larvæ, which form cocoons before winter sets in, and hibernate as pupæ, the moths from them emerging the following spring.

This species is rery irregular in its development, it being easy to find larre of nearly all ages almost any time during the season. The second brood is usually much more numerous than the first, and consequently the injury is most noticeable in September and October. 
Remedies.-Like so many other orchard insects, this pest may be destroyed by spraying with the arsenites-three or four ounces of Paris green, or London purple, to fifty gallons of water.

\section{INJURING THE FRUIT.}

\section{The Codling Moth or Apple Worm.}

Carpocapsa pomonella.

This is the most generally injurious apple insect, and is probably known wherever the fruit is grown. The small, chocolate moth (Fig. 20, g, f) deposits its eggs in spring in the blossom end of the young

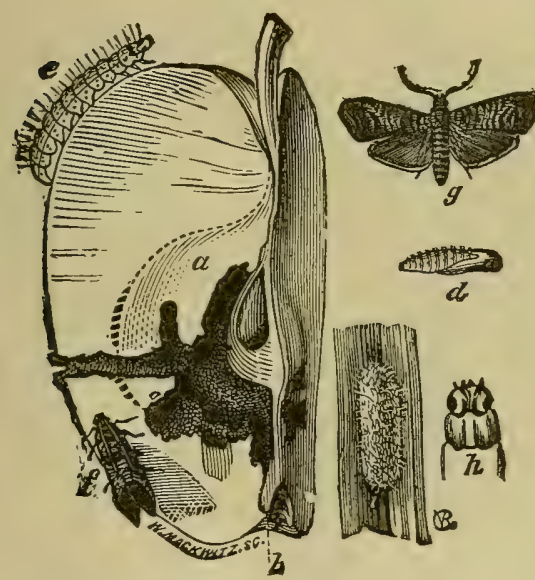

Fig. 20. Codling Moth: $\alpha$, injured apple: $b$, place where egg is laid; $e$, larva; $d$, pupa : $i$, cocoon; $g, f$, moth; $h$, head of larva. apple (b) before the latter has turned down on its stem. From the egg there hatches a minute worm or caterpillar; which nibbles at the skin of the fruit and eats its way toward the core. Here it continues feeding as the apple develops, increasing in size until at the end of three or four weeks it is about three-fourths of an 
inch long, and appears as represented at $e$. It has now finished its caterpillar growth, and, leaving the apple, finds some crevice in the bark where it spins a rather slight silken cocoon in which it changes to a pupa. It remains in this condition about a fortnight, when it emerges as a moth like the one by which the original egg was laid. Thus the life cycle is completed. There are at least two broods in a season.

Remedy. - The best remedy for this insect is that of spraying with the arsenites-Paris green or London purple-in spring, soon after the blossoms have fallen off, when the apples are from the size of a pea to that of a hickory nut, and before they have turned downward on their stems. A second application, ten days or two weeks after the first, is generally advisable. The poisons may be used in the proportion of one pound to 250 gallons of water. The spraying should be done with some kind of spraying pump and nozzle.

Besides destroying the Codling Moth, spraying at the times indicated will largely prevent the injuries of the various leaf-eating caterpillars and the Plum and Apple Curculios.

\section{The Apple Maggot.}

Trypeta pomonella.

The injury of this insect is at once distinguished from that of the Codling Moth from the fact that while the latter is largely confined to the region of 
the core, the Apple Naggot feeds indiscriminately through the pulp of the fruit, burrowing in every direction, as represented at Fig. 21. The larvæ

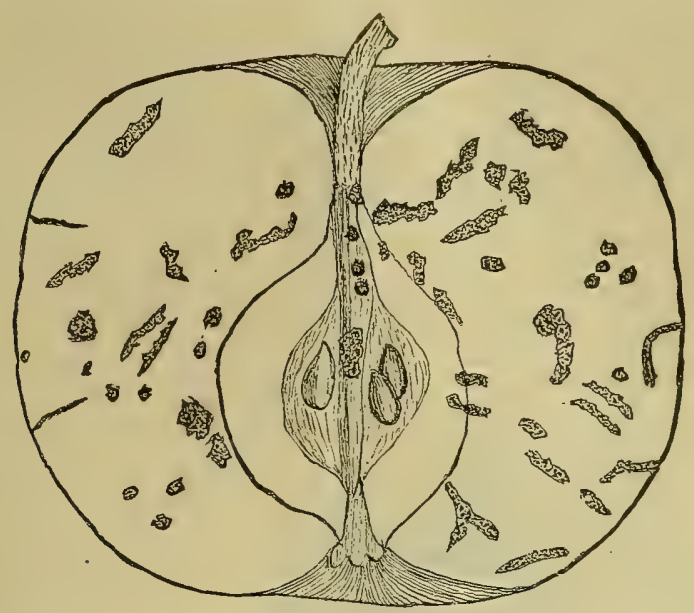

Fig. 21. Apple cut open, showing injury of Apple Maggot.

themselves are also different, that of the Codling Moth having six legs, while the Apple Maggot is footless.

The adult of the Apple Maggot is a two-winged fly that appears early in summer and deposits eggs in the partially grown apples. These eggs are inserted, one in a place, through the skin of the fruit. In a few days they hatch into maggots, that tunnel the fruit in all directions, becoming full grown in five or six weeks, when they are whitish or greenish white, and about a quarter of an inch long. They then leave the fruit, and generally go into the soil 
an inch or less, where they change to the pupa state. They remain in this condition until the following summer, when they emerge as flies again.

Remedies.-This insect is an exceedingly difficult pest to contend with. Fortunately, as yet, it is only seriously injurious in comparatively few states. The destruction of all refuse or infested fruit, such as windfalls, apple pomace, etc., is the measure most highly recommended.

\section{The Apple Curculio.}

Anthonomus quadrigibbus.

This insect in its adult state is represented magnified at Fig. 22, $c$ showing a back view, and $b$ a side view, while the natural size is represented by the small figure $a$, at the left of $b$. This is a beetle related to the Plum Curculio, but having a longer snout. It is dull brown in color, and has four tubercles, or humps,

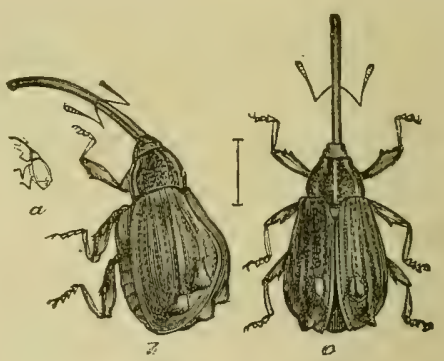

Fig. 22. Apple Curculio. Magnified. on the hinder portion of its back. Before the general cultivation of the improved rarieties of apple, it bred in wild crabs and haws.

The adult beetles drill holes in young apples, both for food and the deposition of eggs. The latter are laid at the bottom of the eavity, and soon hatch into grubs or larvæ that feed upon the pulp of the fruit. 
They usually penetrate to the core, where they continue feeding four or five weeks. They then become

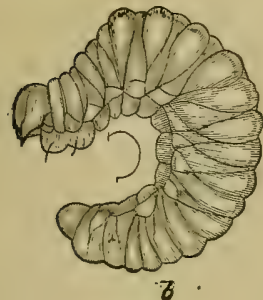

Fig. 23. Apple Curculio: $a$, pupa; $b$, Iarva. Magnified.

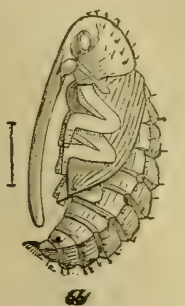

full grown as larvæ, and appear when magnified like Fig. $23, b$, being footless, whitish grubs. The larva pupates within the cavity of the apple where it has developed, the pupa being represented, magnified, at Fig. 23, $a$, and two or three weeks later it a $g$ ain chang es, this time emerging as a perfect beetle, which gnaws its way out through the fruit. There is but one brood

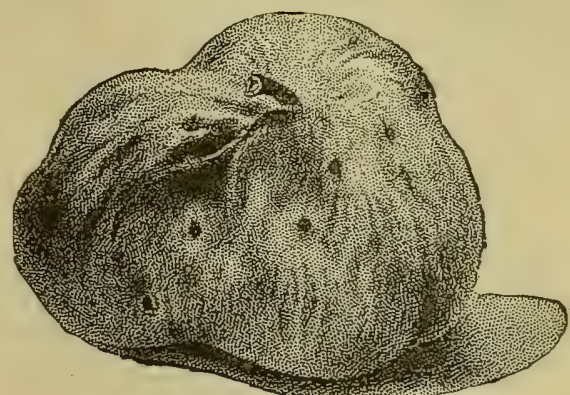

Fig. 24. Apple injured by Curculio. each year, the insect hibernating in the beetle state. The fruit attacked by this pest becomes dwarfed, gnarly and ill-shapen, as shown at Fig. 24.

Remedies.-The feeding and egg-laying habits of the adult of this insect render it liable to destruction by poisoning. Consequently spraying with the arsenites; as for the Codling Moth, appears to be a sufficient remedy. 


\section{Other Apple Insects.}

The apple is subject to attack by many insects besides those discussed in the foregoing pages, which, however, include the most injurious pests. The trunk and branche are occasionally infested by the Scurfy Bark-louse (which will be found described on a later page as a pear insect); the leaves are sometimes eaten by various caterpillars besides those mentioned. and the fruit is attacked by the Plum Curculio, as well as by the three species we have discussed. But the treatment recommended will keep in check not only the insects included in our list, but also nearly, if not quite, all of these various other pests.

Summary of Treatment.-Young apple trees should be examined for insects as soon as received from the nursery. If any Woolly Aphids are present on the roots or branches, the affected part should be treated with kerosene emulsion. If the ragged cases of the Leaf Crumpler are attached to the twigs they should be removed and burned.

As soon in spring as the blossoms have entirely fallen, the trees should be sprayed with Paris green and water-3 ounces to 50 gallons. The application had generally better be repeated ten days or two weeks later. This will check both the fruit and leafeating insects. 
Early in summer the trunks and larger branches should be washed with a strong solution of soap and carbolic acid, and the application should be repeated three or four weeks later. This is to prevent attacks of borers. Late in summer or early in fall the trees may be examined for eggs or young borers, which when found should be cut out or crushed with a knife.

It is well also to pick up and feed to stock all windfalls in the orchard. This may be done by turning hogs or cattle irto the field occasionally. Such methods should especially be employed in regions where the Apple Maggot is at work, for this is the only known plan of keeping this pest in check. 


\section{INSECTS AFFECTING THE PLUM.}

\section{INJURING THE TRUNK.}

\section{The Plum-tree Borer.}

Aegeria pictipes.

This insect is seldom abundant enough to do serious injury. The adult is a beautiful, clear-winged moth, closely related to the Peach-tree Borer, to which it is similar in life-history and habits. It is represented, considerably magnified, at Plate II, Fig. 7.

The larva of this insect works mainly in the trunk and branches of the plum, gnawing the inner bark and sapwood. It also affects the wild black and wild red cherry, and is likely occasionally to be found in the cultivated cherry.

Remedies.-The remedy usually recommended for this pest is that of cutting out the larvæ with a sharp knife, according to the plan commonly adopted for the Peach-tree Borer.

\section{INJURING THE LEAVES.}

\section{The Plum-tree Aphis.}

Aphis prunifolii.

The leaves of plum trees are frequently crowded in spring by small, dark-colored, soft-bodied insects. 
that suck out the sap, and give the terminal portion of the twigs a malformed appearance. These are

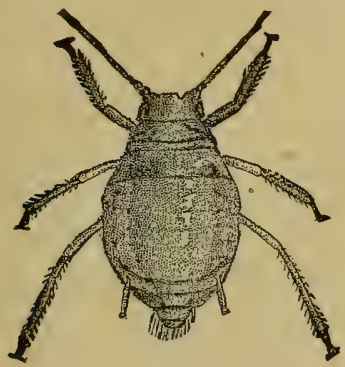

Fig. 25. Aphis. Magnífied. aphides or plant-lice. Two or three species are known to infest the plum, one of which has been shown by Dr. C. V. Riley to migrate during summer to the hop-plant. The life-histories of the others are not very well known. In a general way they are similar to the Apple Aphis, described on a previous page.

Remedies.-Spraying with kerosene emulsion is the most effective remedy for this insect. The application should be made with à force pump and spray nozzle; and as soon after the insects are noticed as possible.

\section{Plum Leaf Caterpillars.}

There are several kinds of caterpillars that occasionally attack the plum, but they rarely occur in sufficient numbers to do serious injury. Of these we may mention the Plum Catocala (Catocala ultronea), the Polyphemus Moth (Telea polyphesnus), the Horned Span-worm (Nematocampa filamentaria), the Plum Sphinx (Sphinx drupiferarum), the Gray Dagger-moth (Apatela occidentalis), and the Disippus Butterfly (Limenitis disippas). These insects are all open to destruction by spraying with the arsenites, and are not likely to become injurious in orchards regularly sprayed for the Plum Curculio. 


\section{INJURING THE FRUIT.}

\section{The Plum Curculio.}

Conotrachelus nenuphar.

This insect, the worst foe of the plum grower, is the cause of the "worminess" and premature dropping of the fruit that so many orchardists are familiar with. Besides plums, it breeds in peaches, nectarines, apricots, cherries, pears and apples.

The adult insect (Fig. 26, c) appears in spring about the time of blossoming, and feeds upon the

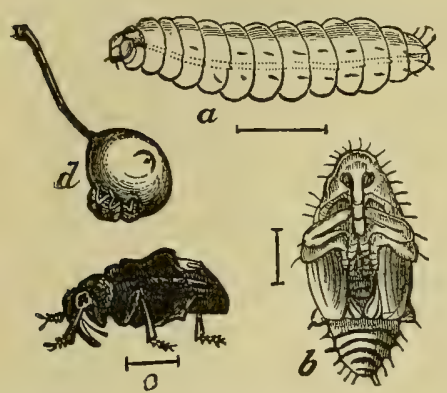

Fig. 26. Plum Curculio; $a$, larva; $b$, pupa; $c$, beetle-magnified; $d$, plum showing crescent mark.

foliage and flowers until the fruit is well 'set.' It then attacks the young plums, gnawing at them to satisfy its hunger, and cutting crescent shaped marks in the skin to deposit its eggs $(d)$. In a short time these eggs liatch into little grubs that feed upon the pulp of the fruit, gradually working toward the pit. In a few weeks they become full grown (appearing when magnified like $a$, Fig. 26), by which time the infested plums have generally fallen to the ground. The larvæ then leave the fruit, and entering the soil a short distance change to pupæ $(b)$. A few weeks later they again change, and come forth as perfect 
beetles. But some of them enter the ground so late that they hibernate as pupæ, emerging the following summer. There is but one brood each season. A single female is able to deposit 150 to $200 \mathrm{eggs}$, ten frequently being laid in a single day.

Certain parasites prey upon this insect, but are seldom sufficiently numerous to prevent its injuries.

Remedies.-Entomologists have been divided in opinion as to whether this insect can be successfully destroyed by spraying with Paris green, but the evidence in hand indicates that this is the best way to fight the pest, especially in orchards of considerable size. This remedy acts by destroying the adult beetles rather than the larvæ. The trees should be sprayed three or four times, at intervals of a week or ten days, beginning as soon as the blossoms have fallen, with Paris green mixed with water in the proportion of 3 ounces to 40 or 50 gallons. The other method of fighting this insect is that of "jarring." This takes advantage of the fact that when a limb on which the Curculio is at work is suddenly jarred, the insect drops to the ground. A large sheet is placed beneath the tree, and the latter is jarred by striking the trunk and larger branches with a padded mallet. The Curculios fall upon the sheet, and are then collected and destroyed. Instead of a sheet, most commercial growers use a sort of inverted umbrella mounted on wheels, which is run beneath the tree. It has sloping sides down which the insects roll into a receptacle in the center, where they are 
caught. There are many patterns of these catchers in use in different sections of the country. The insects are most easily caught in the morning, when the atmosphere is cool.

\section{The Plum Gouger.}

Coccotorus prunicida.

The Plum Gouger is most injurious in the region west of the Mississippi river, being rarely or never. found in the Eastern States. But in. Iowa, and probably, also, in adjacent states, it frequently is more destructive than the Plum Curculio, from which it differs considerably in history and habits. The adult Gouger is a small snout beetle, about the same size as the Curculio, but with a smooth back, and of a yellowish or brownish color. It appears about blossoming time, and soon after the fruit sets begins operations upon it. Instead of cutting a crescent-shaped mark to lay its egg, it gnaws out a little cavity beneath the skin in which the egg is deposited. A few days later the larva hatches, and burrows through the pulp to the pit, gnawing through the soft shell to the 'meaty' portion inside. Here it continues to develop, feeding upon the contents of the pit, rather than the pulp surrounding it. After several weeks it becomes full grown: it then gnaws a hole through the hardening wall of the pit, so it can escape after completing its transformations, and changes to the pupa state inside. A short time afterwards it again changes, this time to the adult, 
and the beetle gnaws its way to the outer world, hibernating in this condition. It is single-brooded.

Like the Plum Curculio, the adult Plum Gouger gnaws pits in the fruit for food. It also has various natural enemies that help keep it in check.

Remedies.-One would suppose from the feeding habits of the Plum Gouger that the adults were liable to destruction by spraying with the arsenites, but experiments made in Iowa by Prof. C. P. Gillette do not confirm this opinion. However, the matter seems not to have been thoroughly tested on a large, commercial scale. If spraying is ineffective, recourse must be had to the jarring method.

\section{Other Plum Insects.}

The base of the trunk of the plum tree is occasionally attacked by the Peach-tree Borer; and the upper portion of the trunk is sometimes infested with the Flat-headed Apple-tree Borer. The leaves are attacked by a large proportion of the caterpillars that feed on the foliage of the apple, as well as the Pear or Cherry Slug, the Grape-vine Flea-beetle, and a number of other insects. But spraying is a safe specific for nearly or quite all of these defoliators.

Summary of Treatment.-As soon as the blossoms have all fallen, and never before, spray trees with Paris green and water ( 3 ozs. to 50 gals.), and repeat the operation two or three times at intervals of ten days or two weeks. This will largely or entirely prevent the injuries of the fruit and foliage 
pests. The leaves of many varieties of plums are easily injured by the arsenites, so that much care should be taken in spraying, not to use too strong a mixture, nor to get too much on the tree. Paris green is preferable to London purple for this purpose, when tender classes of fruits are to be operated upon. In using Paris green the mixture must be frequently stirred to make sure that the poison does not settle to the bottom of the vessel and thus render the applications of unequal strengths. It is well after each barrel of liquid is used to draw off all the residue in the bottom.

If the aphides or plant-lice become too numerous in spring, spray with kerosene emulsion. 


\section{INSECTS AFFECTING THE PEAR.}

\section{INJURING THE TRUNK.}

\section{The Pear-tree Borer.}

Aegeria pyri.

The adult of this insect is represented twice its natural size at Plate II, Fig. 3. It is a small, clearwinged moth, purplish or bluish-black in color, and having three pretty golden-yellow bands across the abdomen. Its eggs are deposited upon the bark of the trunk, and the larvæ feed upon the inner bark or sapwood. The latter are very similar to the grubs of the Peach-tree Borer, but are considerably smaller. When full grown they gnaw almost through the outer bark, leaving an extremely thin layer to protect them, and then change to the chrysalis state within the burrow. A short time afterwards the chrysalis wriggles through the burrow to the outer membranous bark, through which it pushes its front end. The fully developed moth then crawls out of the chrysalis, and, after drying its wings, flies away in search of companions and the nectar of flowers upon which it feeds.

Remedies.-This insect is rarely present in injurious numbers, and consequently usually requires little or no attention. The larva are said to throw out fine, sawdust-like castings, by which their presence may 
be detected. When this happens they should be carefully cut out with a sharp knife. Painting the bark with the soft soap and carbolic acid mixture mentioned on page 20 is also recommended.

\section{INJURING THE BRANCHES.}

\section{The Scurfy Bark-louse.}

Chionaspis furfurus.

During the winter months the bark of pear and apple trees is frequently more or less covered by small, flattened, whitish, oval scales (Fig. 27), beneath which are numerous minute purple eggs. These are the scales of the female Scurfy Bark-louse, an insect that seems to be more destructive in the Southern and Central States than at the North. It is probably

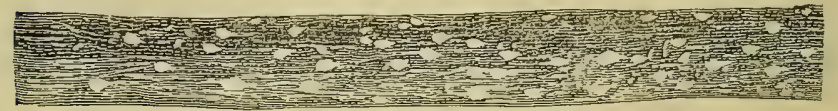

Fig. 27. Twig infested by Scurfy Bark-louse.

a native of America, having been known to the earliest American entomologists, and is supposed to have fed on wild crab apples before the introduction of improved fruit trees. The scales of the male louse are much narrower than those of the female.

During May or June the eggs beneath these scales hatch into small, purplish or reddish-brown lice, that crawl about over the bark for a few days, and finally 
insert their tiny beaks to suck the sap. Having thus fixed themselves they gradually develop, until by fall the females have attained the shape represented at the left of Fig. 28, and the size shown at the right of the same figure. The eggs are deposited beneath the scale, and remain in this position until the following spring.

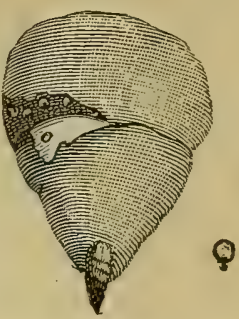

Remedies.-The treatment recommended on a previous page (p. 34) for the Oyster-shell Bark-louse, is equally applicable to the present species.

INJURING THE LEAVES.

\section{The Pear-tree Slug.}

\section{Selandria cerasi.}

The leaves of pear, cherry, quince and plum trees are frequently attacked during June and July by a greenish-black, slimy slug, that eats the parenchyma off the upper surface. This is the Pear or Cherry Slug: It originates from eggs laid early in June, in the leaf, by a four-winged black fly. (shown slightly magnified at Fig. 29). The eggs liatch about two weeks after they are deposited, and the larve become full grown in four or five weeks. They are then nearly half an inch long, and of the form represented at Fig. 29. They now shed their slimy skin, appearing in a clean, yellow suit that is not sticky, 
and shortly afterwards leave the tree. Having reached the ground they enter the soil two or three inches, and form an oval cavity in the earth, which

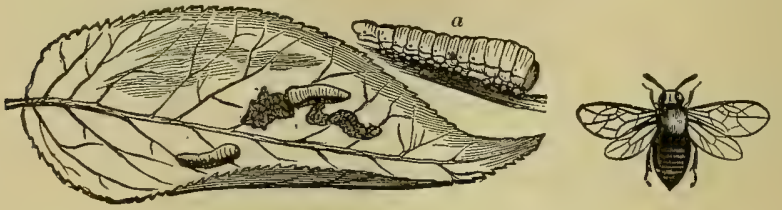

Fig. 29. Pear-tree slug: fly and larvæ.

they line with a glossy secretion. The larval skin is now cast, and the insect becomes a pupa. About a fortnight later it again changes, this time to a four-winged fly, that escapes to continue the propagation of the species. There are two broods each season in the Northern States, the first brood of larvæ appearing in June, and the second in August. The winter is passed in the pupa state.

Remedies.-This Pear Slug is very easy to destroy, and should be checked as soon after it begins operations as possible. Spraying with the arsenites, or pyrethrum, or hellebore, is a simple and effectual remedy. Or these substances may be dusted on with. a bellows gun.

\section{The Pear-leaf Mite.}

Phytoptus pyri.

The leaves of the pear are sometimes noticed in spring to have small reddish spots upon their upper surface. As the season advances these spots become darker colored, and finally appear almost black, the 
tissues of the leaf where they are being dry and dead. This is caused by the Pear-leaf Mite, an extremely minute creature, related to the Red Spider found in greenhouses.

It reproduces by means of eggs laid within the galls - the discolored spots already mentionedwhich hatch into little mites that sometime afterwards leave their birth place, and burrow into the tissue of a healthy portion of the leaf. Here they

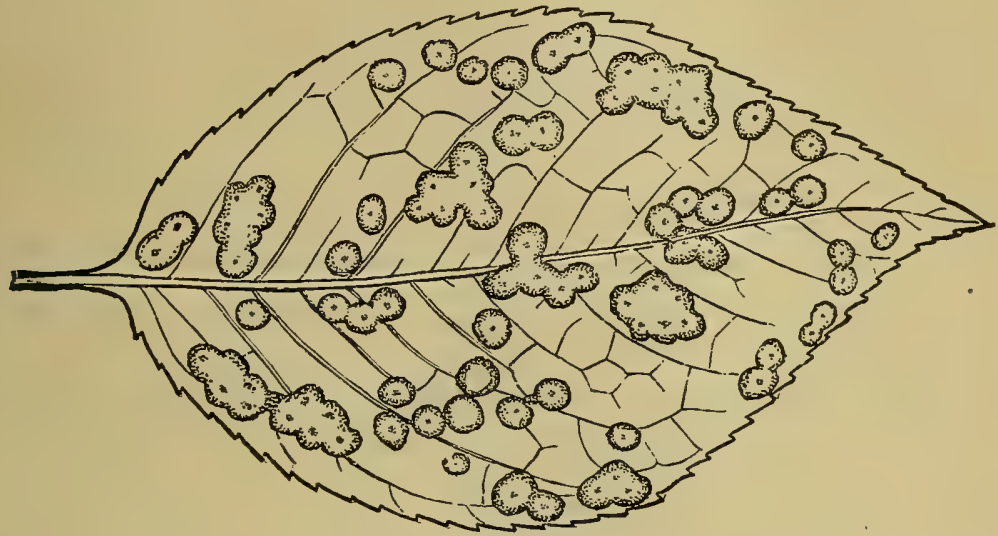

Fig. 30. Leaf injured by Pear Mite.

feed upon the leaf-substance, forming a new gall, and starting another generation of their kind. As autumn approaches and the leaves become dry, the mites desert them, migrating to the twigs, where they gather on the buds, and penetrate between the leafy scales, a situation in which they pass the winter.

Remedies.-This pest is difficult to fight. So long as it remains in the tissues of the leaves it is 
beyond the reach of insecticides, and as it deserts the leaves before they fall, gathering and burning them in autumn will do little or no good. It seems probable, however, that by spraying with kerosene emulsion two or three times in autumn, when they are migrating to the twigs, and before they have penetrated deeply between the scales, a large proportion of them would be destroyed.

\section{INJURING THE FRUIT.}

\section{The Codling Moth and Plum Curculio.}

These pests are the worst insect enemies of the fruit of the pear. To the first is due the "worminess" that spoils so large a portion of the crop, and to the second a large part of the gnarly, knotty fruit that is so often seen. Spraying with Paris green is fortunately an effectual preventive of the injuries of both.

\section{Other Pear Insects.}

The trunk of the pear tree is subject to attack from both the Round-headed and Flat-headed Apple-tree Borers. The remedies mentioned as applicable to the apple are equally so to the pear. The branches are sometimes infested by the Oyster-shell Bark-louse, the Pear-tree Bark-louse (Lecanium pyri), and the Pear-tree Psylla (Psylla pyri), as well as the Pearblight Beetle (Xyleborus pyri). The leaves are also liable to attack from a great variety of caterpillars, which, however, are seldom seriously injurious. 
Summary of Treatment.-Soon after the blossoms have fallen, spray the trees with Paris green in water mixture-3 ounces to 50 gallons-to destroy the Codling Moth and Curculios. Repeat the application ten days or two weeks later. If the Pear-tree Slug appears in the latter part of June, spray again then. In the case of danger from the bark-lice or apple-tree borers, carry out treatment recommended under the special heads.

Some authors recommend that in case the Pearleaf Mite becomes injurious the trees be thoroughly pruned in winter, removing and burning as many of the buds in which the mites are concealed as possible without injuring the trees. 


\section{INSECTS AFFECTING THE CHERRY.}

INJURING THE TRUNK.

\section{The Flat-headed Cherry-tree Borer.}

\section{Dicerca divaricata.}

This insect is closely related to the Flat-headed Apple-tree Borer, to which it is similar in life-history and habits. The adult, a handsome, brassy or copper-colored beetle, about four-fifths of an inch long, deposits eggs during the summer on the trunk of the wild and cultivated cherry. These eggs hatch into larvæ that bore through the bark to the sapwood, upon which they live. They gradually grow larger until, when full grown, [they resemble Fig. $10 a$. They then pupate, and shortly afterwards again change to the beetle state.

Remedies.-Fortunately this borer is rarely seriously injurious. Should it become so, the treatment recommended for the Flat-headed Apple-tree Borer would be also applicable in this case.

\section{INJURING THE LEAVES.}

\section{The Cherry Aphis.}

Myzus cerasi.

The twigs and under surface of the leaves of the cherry are frequently thickly infested during May 
and June by small, shining black plant-lice, that suck out the sap and deform the leaves. This insect is the Cherry Aphis. The wingless form is represented much magnified at $a$, Fig. 31, and the winged

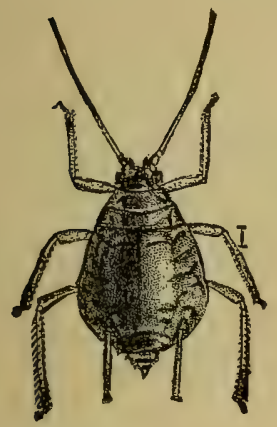

$a$

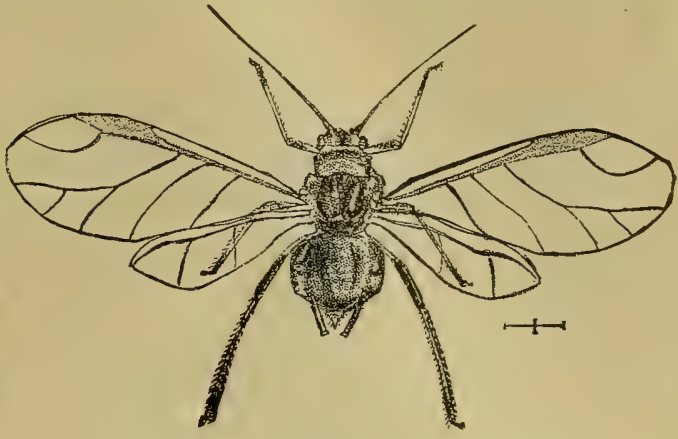

$b$

Fig. 31: Cherry Aphis : $a$, wingless female; $b$, winged female. Magnified. form at $b$ of the same figure, the straight limes at the right indicating the natural size.

The Cherry Aphis winters over on the twigs in the egg state. Early in spring the eggs hatch into young aphides that crawl upon the bursting buds, inserting their tiny sap-sucking beaks into the tissues of the unfolding leaves. In a week or ten days they become full grown, and begin giving birth to young lice, which also soon develop, and repeat the process. In this way they increase with marvellous rapidity. Most of these early spring forms are wingless, but during June great numbers of winged lice appear, and late in June or early in July they leave the cherry, migrating to some other plant, although we do not yet know what that other plant is. Here they 
continue developing throughout the summer, and in autumn a winged brood again appears and migrates back to the cherry. These migrants give birth to young that develop into egg-laying females, which deposit small, oval, shining black eggs upon the twigs about the buds.

Remedies.-Lady-beetles and certain predaceous and parasitic flies prey upon these little pests in great numbers, and often aid materially in checking their injuries. The best artificial remedy is that of spraying with kerosene emulsion.

\section{The May Beetle.}

Lachnosterna fusca.

The leaves of cherry and other fruit trees are sometimes eaten early in summer by the common May Beetle or June Bug (Fig. 32). This insect is
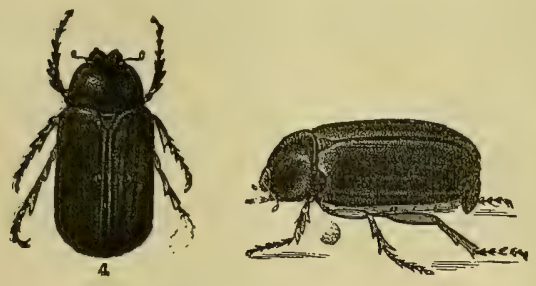

Fig. 32. May Beetle. the parent of the mischievous White Grub, that is so frequently destructive in meadows a $\mathrm{n}$ pastures. The beetles feed upon the foliage at night, and sometimes appear in sufficient numbers to do much damage before their presence is discovered. 
Remedies.-Spraying the infested trees with the arsenites, Paris green or London Purple, is the most promising method of preventing their injuries.

\section{The Cherry-tree Leaf-roller.}

\section{Cacoecia cerasivorana.}

One occasionally finds the leaves of a cherry twig. fastened together in a large, compact nest, inhabited by numerous yellow caterpillars, that feed upon the enclosed leaves. This is the Cherry-tree Leaf-roller. The adult is a small brown moth which deposits a: large number of eggs upon the twig. The caterpillars on hatching fasten the leaves together and develop within the tent thus formed. They become full grown about midsummer, and pupate within the nest. In a week or so they are ready to change again, and the pupæ work their way out until they are nearly free from the nest, remaining attached by the hinder portions of their bodies. The skin then splits along the back and the moths come out.

Remedies.-These nests are so conspicuous that it is a simple matter to cut and burn the infested twigs, thus ending the career of the pests.

\section{The Pear-tree Slug.}

Selandria cerasi.

This insect is probably as destructive to the cherry as to the pear, under which we have already discussed it. Its life-history on the two fruits is similar, and the remedies are the same in both cases. 


\section{INJURING THE FRUIT.}

\section{The Plum Curculio.}

Conotrachelus nenuphar.

This insect, which has already been discussed under the plum (p. 60), is also exceedingly injurious to cherries. The latter, however, usually do not fall off when infested by the Curculio larvæ, but remain on the tree until the fruit ripens. The remedial measures suggested in connection with the plum are equally applicable to this fruit.

\section{Other Cherry Insects.}

There are a large number of caterpillars that feed upon the leaves of cherries, but they rarely do noticeable injury, and spraying with the arsenites will keep nearly if not quite all of them in check.

Summary of Treatment.-Spray the trees as soon as blossoms have fallen, with Paris green-3 ounces to 50 gallons water. Repeat the operation once or twice at intervals of ten days. If the Leaf Slug appears about the time the fruit is beginning to ripen, spray with pyrethrum, 8 ounces to 50 gallons. If aphides or plant-lice appear, spray with kerosene emulsion. The second brood of Slugs, developing after the fruit is harvested, may be destroyed by spraying with Paris green or London purple. 


\section{INSECTS AFFECTING THE PEACH.}

\section{INJURING THE ROOT.}

\section{The Peach-tree Borer.}

\section{Sannina exitiosa.}

The Peach-tree Borer is a soft, whitish caterpillar, with a reddish-brown head, and sixteen legs. It hatches from eggs laid during the summer months by a handsome, day-flying moth, upon the bark of the trunk, at or near the soil surface. After hatching, the young larvæ burrow through to the inner bark and sapwood of the larger roots, upon which they feed, causing a gummy exudation that betrays their presence. They continue feeding in this way for nearly a year, being interrupted of course during the winter months, when they kecome full grown as larvæ. They then usually approach the top of the ground within an inch or two of the soil surface, and construct cocoons of the gummy exudation, their castings and silk. Within these cocoons they change to the pupa state, and three or four weeks later again change to moths. The two sexes of the moths are represented twice natural size at Plate II-Fig. 1 representing the male, and Fig. 2 the female. These moths are present more or less all summer : although there is but one generation a year, the larve reach maturity at such different times that they keep up a 
nearly constant supply of the imagos. On this account one can find larvæ of various sizes in the roots at almost any time. This insect also occasionally infests the plum.

Remedies.-Probably the surest, and certainly the most generally practiced, method of preventing the injuries of this insect is that of cutting out the larvæ in the fall or spring, or both. To do this the earth is removed from about the base of the tree, and wherever the gummy exudation indicates that a borer is at work, a sharp knife is inserted to dig him out. It is often necessary to open the larval channels for some distance before the depredator is found. Instead of digging the larvæ out some growers destroy them by applying scalding hot water. With this method the earth is removed as before, and the gummy exudations scraped away before the water is applied.

Some growers prevent the deposition of eggs by mounding the soil up about the base of the trunk, a foot or more, late in spring, removing it in September. The chief objection to this method appears to be that it is liable to make the bark too tender to stand the winter. Others protect the base of the trunk by fastening paper or straw around it, so as to cover the bark. A preventive measure that has sometimes been recommended, which seems worthy of extended trial by commercial growers, is that of spraying the base of the trunks with a strong mixture of Paris green and water (say a pound to 50 gallons) to which 
has been added some glue. The idea is that in this way the bark will be so coated with poison that many of the young larvæ will be destroyed while eating their way through to the sapwood.

\section{The Black Peach Aphis.}

Aphis persicæ-niger.

This is a shining black aphis, that occurs in great numbers upon the roots, twigs and leaves of the peach in the Atlantic States. The root-infesting specimens seem to be especially injurious, causing an enfeebled condition of the tree that has sometimes been mistaken for the disease known as ' the yellows.' These insects reproduce viviparously, or by giving birth to living young, and, consequently, like other aphides, they are able to multiply with remarkable rapidity. There are two forms, one wingless and the other winged, both having shining black bodies; and sucking out the sap of the tree through their tiny beaks.

Remedies.-The best results seem to have been attained in fighting the under-ground form of this insect by digging into the soil about the roots refuse tobacco, either in the form of powder or stems. Kainit is also said by New Jersey peach-growers to serve a similar purpose. The aerial specimens are open to destruction by spraying with kerosene emulsion. 


\section{INJURING THE LEAVES.}

\section{The Peach Aphis.}

Myzus persicx.

This insect is much like the one last discussed, with which, in fact, it has frequently been confused, but it appears to be distributed over a much wider area, being found in nearly all portions of the United States where peaches are grown. Like other aphides, it damages the tree by sucking out the sap, through the leaves or tender twigs. It is a soft, blackish little creature that, during the spring and summer months, reproduces by giving birth to living young, and winters over in tiny, black eggs, laid in September or October, upon the twigs about the buds.

Remedies.-Spraying with kerosene emulsion is the best method of destroying these little pests.

\section{INJURING THE FRUIT.}

\section{The Plum Curculio.}

Conotrachelus nenuphar.

This insect, whose life-history has already been treated of on page 60 , breeds in peaches, as well as in plums, cherries, apples and other fruits. It is especially liable to injure peaches when there is a failure of the apple crop. It is more difficult to prevent 
its injuries on this crop than on the apple or plum, because ordinarily it is impracticable to jar peach trees, and their foliage is so easily injured by the arsenites that spraying must be done with great caution, if at all. London purple should never be applied to the leaves of peach trees, and Paris green only in very weak mixtures and early in the season, when the waxy covering of the leaves serves as a protection. Experiments by Professor L. H. Bailey of Cornell University, indicate that Paris green may safely be applied to the peach mixed with water at the rate of two ounces to fifty gallons. One or two sprayings, soon after the fruit sets, will probably help greatly in preventing curculio injury.

\section{Other Peach Insects.}

The trunk of the peach is sometimes infested by the Flat-headed Borers of the Apple and Cherry, though not often. The branches are- subject to the attacks of the Peach-tree Bark-louse (Lecanium persicæ) and the New York Weevil (Ithycerus noveboracensis); while the leaves are more or less affected by a great variety of caterpillars, which; however, rarely do any serious injury.

Summary of Treatment.-In the Atlantic States, dig refuse tobacco about the roots of any trees that appear to be suffering by attacks of the Root Aphis. Adopt some of the plans mentioned on page 78 for fighting the Peach-tree Borer, and carry them 
out. If the trees are to be sprayed to prevent the 'worminess' caused by Curculios, it must be done very carefully, and only early in the season. A good quality of finely powdered Paris green should be used, and the application should be made with a nozzle throwing a fine spray, as experiments have shown that a coarse spray is much more liable to injure the foliage than a fine one.

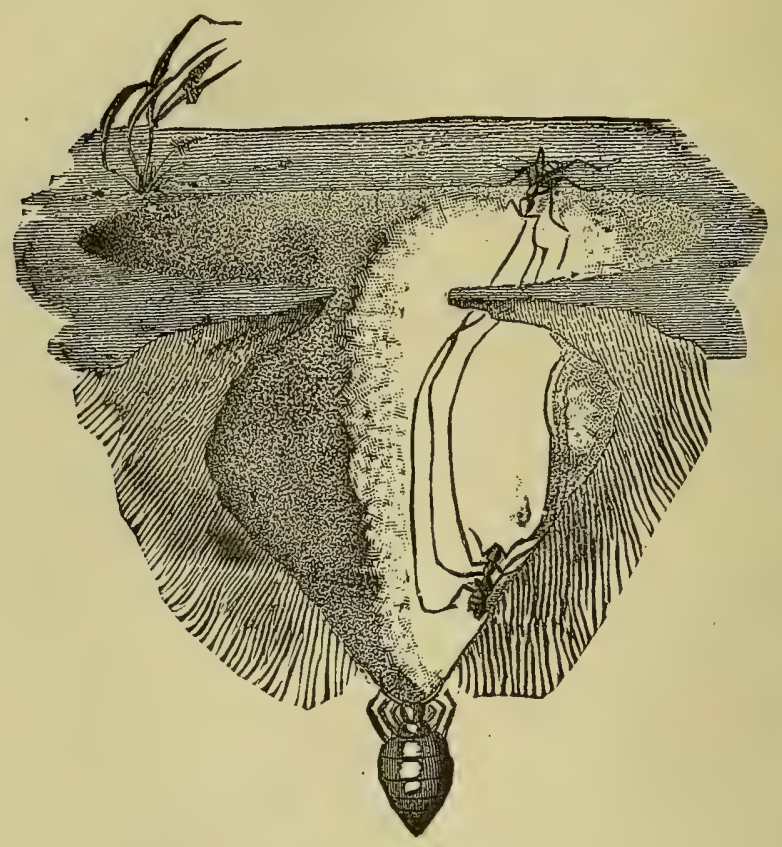




\section{PART II.}

INSECTS

AFFECTING SMALL FRUITS. 


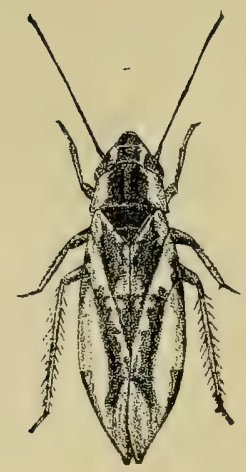

1.

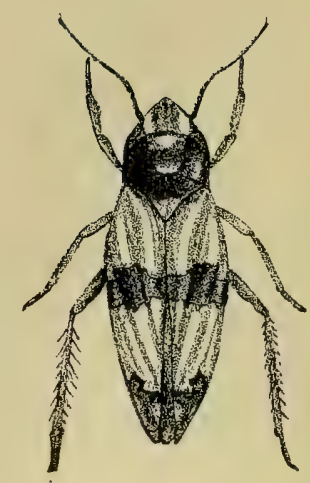

2.

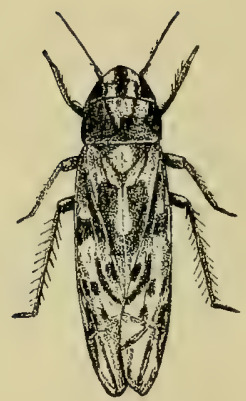

3.

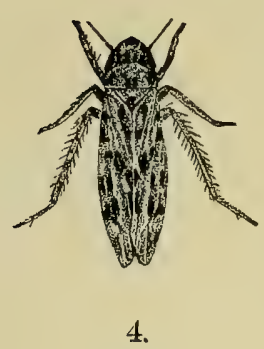

4.

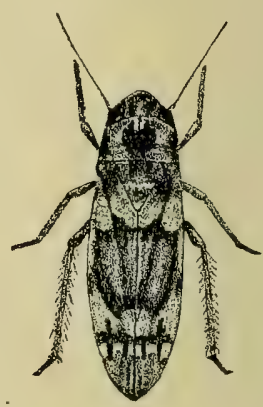

5.

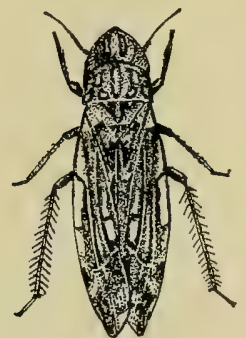

6.

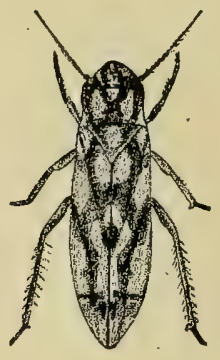

7.

PLATE III.-A Group of Leaf-hoppers. (magnified.) 


\section{INSECTS AFFECTING THE STRAWBERRY.}

\section{INJURING THE ROOT.}

\section{The Strawberry Root-worms.}

Paria aterrima, Graphops pubescens, and Scelodonta nebulosus.

In the larval stage the three species of beetles named above feed upon the fibrous roots of the strawberry, often doing a great deal of damage. They are quite similar in life history and habits, all depositing eggs about the base of the plant, that hatch into small, whitish grubs. The grubs feed upon the strawberry roots, increasing gradually in size. When fully grown they are of the form represented, very greatly magnified, at Fig. 33. They then pupate in earthen cells in the soil, and soon after emerge as beetles, one species of which is shown much Fig. 33. Strawberry Root-worm. 'Greatly magnified. magnified at Fig. 34. The beetles feed upon the foliage of the strawberry, often doing a noticeable damage. The injury of these insects in the larval 
state is frequently mistaken for that of the Strawberry Crown-borer-an entirely different species.

Remedies.-These little insects are difficult to deal with on account of the underground habits of the larve, and the different times of development of

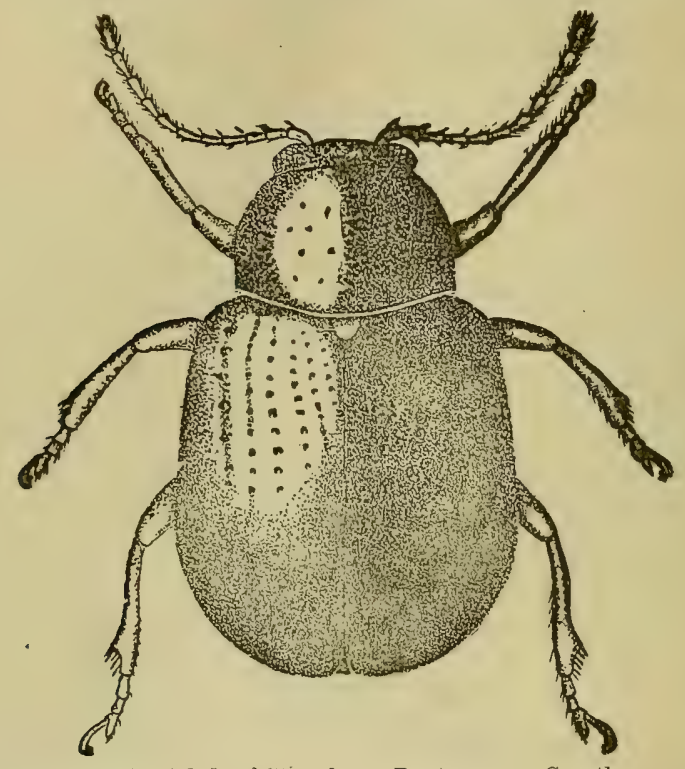

Fig.-34. Adult of Strawberry Root-worm. Greatly magnified.

the adults. Professor Forbes recommends spraying or dusting the foliage with Paris green or London purple occasionally, after the fruit is harvested, to destroy the leaf-eating beetles. Badly-infested fields should be plowed up soon after the crop is gathered. Old, unused strawberry fields should not be left as breeding grounds for these and other strawberry pests. 


\section{The Strawberry Crown-miner.}

\section{Anarsia lineatella (?)}

This is a small, reddish caterpillar (Fig. 35) that bores the strawberry crown, making irregular channels through it in all directions. It becomes fully grown early in summer, and changes to the chrysalis state, to emerge two or three weeks later as a small, dark-gray moth. Eggs are deposited by this moth upon the crown of the plant, and soon hatch into minute larva Fig. 35 . The Strawberry that bore the crown again, becom-
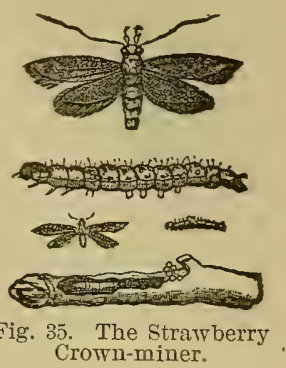
ing partially grown before winter, and hibernating within their burrows. This is the life history of the species in Canada; probably farther south there may be two broods a year.

Remedies.-No successful remedy for this insect is known. Badly infested fields would probably have to be plowed up, and this should be done. preferably in the fall or early spring.

\section{The Strawberry Crown-borer.}

Tyloderma fragariæ.

This insect has been known for many years as one of the most destructive enemies of the strawberry in the great small-fruit fields of the Mississippi T'alley. 
The larva (Fig. 36, a) is a whitish, footless, yellowheaded grub, about one-fifth of an inch long, that lives in the crowns of strawberry plants, frequently hollowing them out so much that the vines are weakened or destroyed. The adult insect is a small,
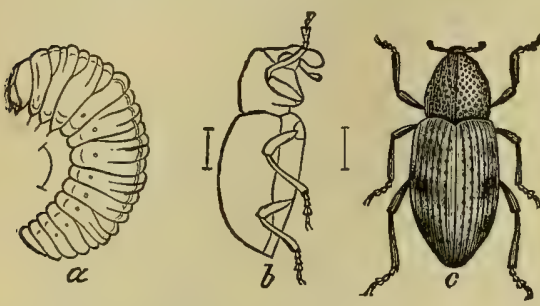

Fig. 36. Strawberry Crown-borer: $a$, larva $b$, beetle, side-view ; $c$, beetle, back view. $\mathrm{d}$ a rk-colored, snout-b e e tl e, about a fifth of an inch long, and of the form represented at Fig. 36, $b, c$. It is unable to $\mathrm{fly}$, because of the rudimentary condition of its membranous wings. According to Professor Forbes "the eggs are laid on the crown in spring, being pushed down among the bases of the leaves. The larvæ penetrate the crowns soon after hatching, and excavate the interior all summer, until they get their growth. A single larva does not wholly destroy a plant, as it matures about the time a quarter or a third of the substance of the crown is devoured. Frequently two or three or more beetles will attack a single stool, and they then leave behind them only a hollow shell to which the roots are attached. Still in its subterranean cavity the worm transforms to a pupa, and in the samesafe retreat effects also the final change to the mature beetle, this last transformation occurring all the way along from August to October, during a period of about two mouths. The beetles all escape from the 
crowns in autumn, but are not known to lay any eggs until the following year. They pass the winter as adults in the fields infested by them as larvæ. It feeds while a mature insect upon the tissues of the plant."

Remedies.-This insect is especially liable to injure old strawberry fields, or those which are replanted to this fruit without some other crop intervening. On account of the inability of the beetle to fly, it is not likely to pass from one plantation to another to deposit eggs, and the isolation of new plantations from old ones is consequently to be desired. If the plants for the new field must be taken from an infested patch, they should be dug up as early as possible to guard against transporting eggs or larvæ with them. It is probable that spraying the fields with the arsenites late in summer will lead to the poisoning of many of the beetles, and that burning the fields, after picking, will prove beneficial. In case infested patches are to be plowed under, this should be done late in June or early in July, to destroy the half-grown larvæ then present. in the crowns.

\section{INJURING THE LEAVES.}

\section{The Strawberry Leaf-roller.}

Phoxopteris comptana.

This is a small, brownish caterpillar that folds the leaflets of the strawberry by bringing the rpper 
surfaces together and fastening them by silken cords (Fig. 37), and feeds upon their substance till they

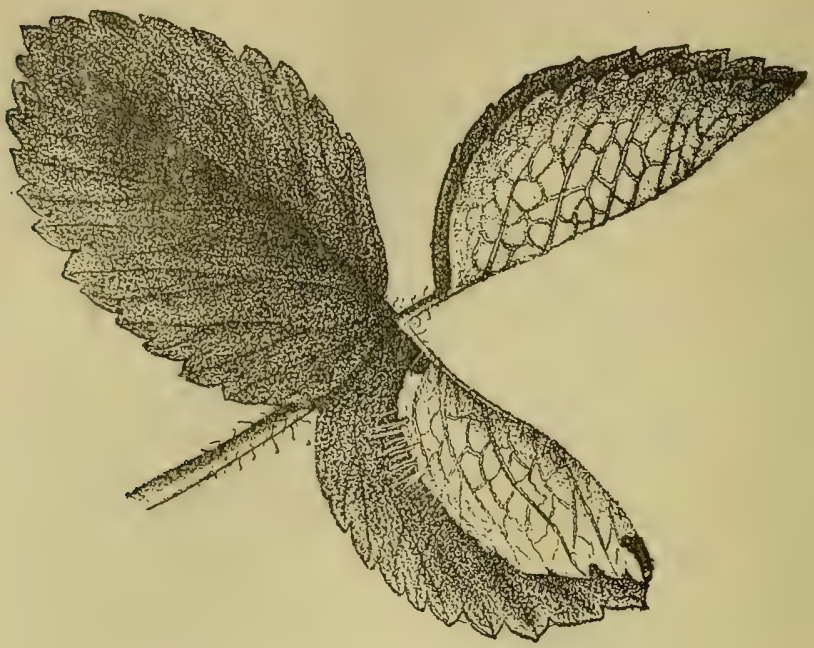

Fig. 37. Strawberry leaf folded by Leaf-roller.

look brown and scorched. It is sometimes exceedingly destructive, and has been considered by some entomologists the most injurious of the insect enemies of the strawberry. It probably occurs in nearly all the Northern states; and, is also found in Europe, where, however, it is does not prove troublesome. It hatches from eggs laid in spring upon the strawberry plants by a small, reddish-brown moth, which is accurately represented slightly magnified at Fig. .38, c. The larva attains its full growth in June, 
when it is nearly half an inch long, of a brownish or greenish color, with a shining, yellowishbrown head. It is represented
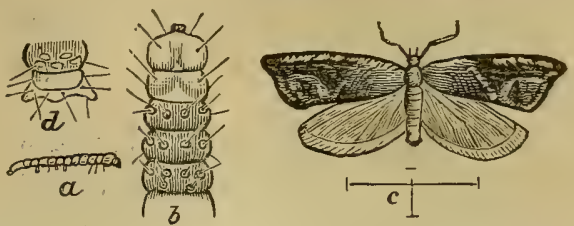
natural size at Fig. 38. Strawberry Leaf-roller: $a$, larva, natural Fig. $38, a$; the size; $b$, front of larva; $c$, moth; $d$, hiarva; $b, c$, and $d$ magnified. head and anterior segments of the body are shown at $b$, and the posterior extremity at $d$ of the same figure. The larva pupates within the rolled leaf, and about midsummer emerges as a moth. These moths deposit eggs for a second brood of caterpillars that feed upon the leaves late in summer, changing to pupæ early in autumn, and, passing the winter in that condition, emerge again as moths the following spring, thus completing the cycle of the year. In the Southern States there are three, and possibly four, broods a year.

Remedies.-The best way to destroy this pest is to mow the field soon after the strawberry crop is gathered, and after leaving it a day or two to become dry, burn it over. This will destroy the leaf-rollers as well as several other kinds of insects, and the spores of fungous diseases. It is sometimes necessary to scatter a little straw over the field where the leaves are not thick enough to burn well. The plants will not be damaged, but will soon send up a new lot of leaves that will grow rapidly, and be free from insect and fungous attack. If for any reason this method 
is not desirable, the insects of the second brood may be destroyed by spraying or dusting the plants in August with some poisonous insecticide.

\section{The Strawberry Slug.}

Emphytus maculatus.

The transformations of this insect have been well represented by Dr. Riley at Fig. 39. The four-winged fly (3) aprears in spring, and deposits its eggs within the tissues of the leaf or stem. The larvæ hatch in a short time, and feed upon the leaf, gnawing small, circular holes at first, like those eaten out of currant.

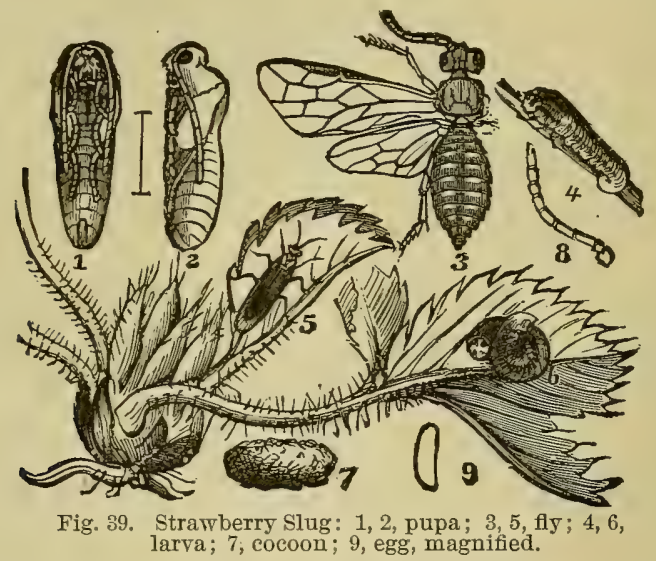

and gooseberry leaves by young Currant Worms.. They develop in five or six weeks into pale-green worms $(4,6)$ about three-fourths of an inch long. The larvæ now go slightly beneath the surface, where they form cocoons ( $y$ ) within which they change."to. 
the pupa state (1,2), and later emerge as flies. In the Southern States there are two broods each season, while at the North there appears to be but one.

Remedies.-The Strawberry Slug is especially liable to injure young, non-fruiting plantations, where it may easily be destroyed by spraying or dusting with Paris green. On fruiting plantations this method may be used in localities where a second brood of larvæ appears after the fruit is gathered. Pyrethrum or insect powder may be used in such cases on the first brood. It is probable that burning the fields over early in summer after the crop $i^{\text {s }}$ gathered will help to hold this insect in check.

\section{INJURING THE FRUIT.}

\section{The Tarnished Plant Bug.}

Lygus pratensis.

This is a small, yellowish-brown or yellowish-green. bug, more or less mottled with dusky, about one-fifth of an inch long (Fig. 40), which is extremely common in nearly all parts of the United States. It attacks a great variety of plants, subsisting upon the sap, and is especially destructive in the strawberry field on account of its injuries to the young fruit, the growth of which it checks, causing an irregular, malformed appearance Fig. 40 . Turnishknown as 'buttoning.' According to ed Mlannified.

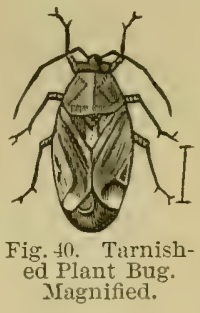


Professor Forbes, "the adults pass the winter under" rubbish and matted vegetation in a variety of situations. With the earliest warm days of spring they venture forth and collect upon whatever tender vegetation of tree or shrub offers them a supply of sap within the reach of their rather slender beaks. On their food plants they lay their eggs. The young soon appear, mingled with the adults as early as the latter part of April and the first of May (in Southern Illinois) and feed with them side by side. By the -middle of May the older individuals have matured, and then all stages may be found together upon the same plants; but the winged forms scatter widely, and in June and July are generally distributed wherever suitable food occurs." There are two, and perhaps more, broods each season. In autumn the adults are to be found abundantly upon goldenrods, sunflowers, asters and various other fall flowers.

Remedies. - As these bugs obtain their food by sucking, they cannot be destroyed by coating their food plants with poisons. The application of pyrethrum (insect powder) has proven the most successful remedy. By means of a powder gun it can be applied quite readily. Kerosene emulsion also destroys them; and it is claimed that the bugs can frequently be collected in insect nets with profit.

\section{Other Strawberry Insects.}

The strawberry is subject to attack by a large number of insects besides those discussed above. 
The roots are often eaten, especially when new plantations are made. on land previously in grass, by white grubs; and the stems are sometimes severed by various species of cut-worms, or pierced by the beak of the Strawberry Weevil (Anthonomus musculus). The blossom is occasionally attacked by a small Thrips (Thrips tritici) that prevents the fertilization of the fruit, and by certain caterpillars that devour it. As to the enemies of the foliage, their name is legion: span-worms, leaf-rollers, Army Worms, plant-lice, etc., all help to swell the list. And the fruit is not neglected: it caters to the dainty appetite of various ants, myriapods, bugs and beetles. But the pests that are most generally and commonly injurious have been included in the previous pages.

Summary of Treatment.-Strawberry plantations should be rotated with other crops every three, or in some cases possibly four, years, and old plantations should never be left unplowed to serve as breeding places for insect pests. It is generally advisable to mow and burn over the field soon aftsr the crop is gathered, a method by which many insect and fungus foes may be held in check. Other treatment must be regulated according to the insects present, and the circumstances accompanying the attack. 


\section{INSECTS AFFECTING CURRANTS AND GOOSEBERRIES.}

INJURING THE STEM.

\section{The Imported Currant-borer.}

Aegeria tipuliformis.

This insect is a small, whitish larva that burrows up and domin the stems of currants, weakening them so that they are checked in growth, and appear stunted and unhealthy. It hatches from eggs deposited singly, on the young stems near the buds, early in summer, by a beautiful, clear-winged, wasplike moth, represented twice natural size at Plate II, Fig. 4 (p. 28). This moth has a bluish-black body, with three golden-yellow transverse bands across the abdomen. It measures from tip to tip of the expanded wings nearly three-quarters of an inch. The wings are transparent except at the borders, where they are brownish-black.

A few days after the egg is deposited it hatches into a small larva that gnaws through the stem to the center, where it feeds on the pith. It continues so to do all summer, making a burrow several inches. in length. When full grown the larva eats nearly through the stem wall, leaving only the membranous outer bark, and then changes to a chrysalis within the burrow. When the chrysalis is ready to transform it wriggles partially out of this opening, 
bursting through the layer of membranous bark. It then rests half way out, its skin splits open in front and the moth crawls out, learing a mere shell behind. The moth dries and expands its wings, and flies away. There is but one brood a year. The gooseberry is only occasionally attacked by this pest.

Remedies.-Cutting and burning infested stems in the spring, before the moths emerge, is the only practicable remedy that has yet been suggested.

\section{INJURING THE LEAVES. \\ The Imported Currant Worm.}

Nematus ventricosus.

This insect is supposed to have been imported into America from Europe about 1858, since when it has

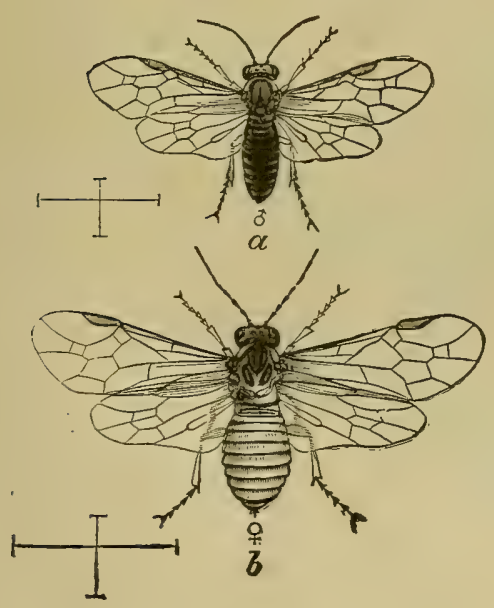

Fig. 41. Currant Worm: $a$, male; $b$, female. Magnified. spread over a large portion of the United States, and has become the most destructive currant insect.

Early in spring the fo u $\mathrm{r}-\mathrm{win}$ ged flies (Fig. 41) emerge from the tough brown cocoons in which they have hibernated, and deposit rows of small, whitish, glassy eggs on the principal veins of the under sides of 
the lower leaves (Fig. 42). In about ten days the small worms hatch and eat circular holes in the leaf, as shown at 2 and 3, Fig. 42. At first these la r $\mathrm{v}$ a $\mathrm{re}$ whitish in color: they soon change to green, then to green with numerous black spots, and at last back again to a plain light green, with

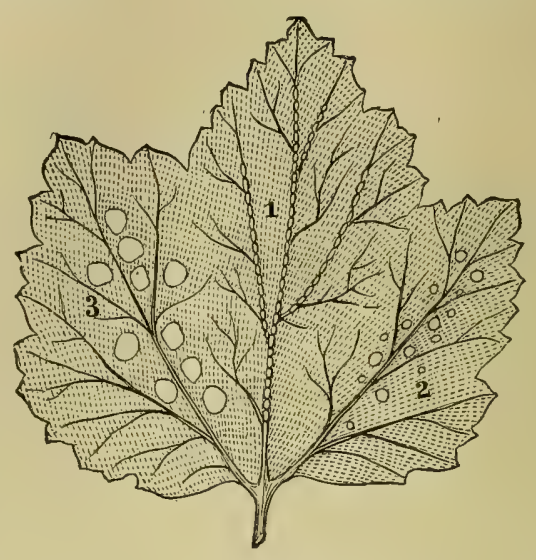

Fig. t2. Currant leaf with eggs of

a tinge of yellow at the sides and ends. They are shown at different ages at Fig. 43. The full grown

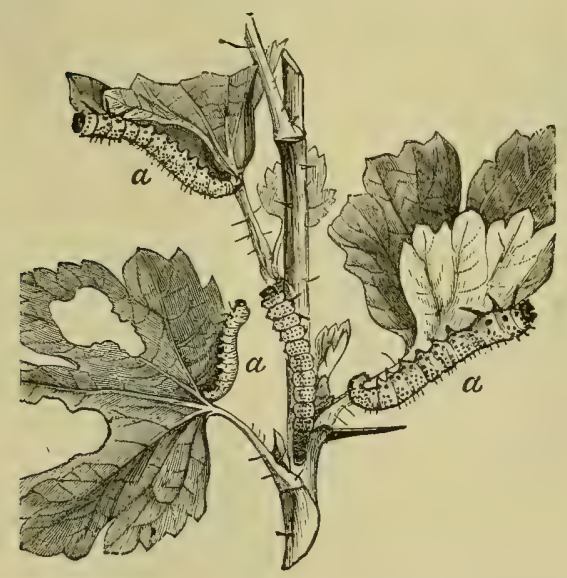

Fig. 43. Currant Worms eating Ieaves. larvæ spin tough brown cocoons, beneath the leaves and rubbish at the surface of the ground, within which they change to pupæ. From these cocoons the flies emerge early in summer, to lay eggs for a second 
brood of worms. As before indicated, the winter is passed within the cocoons, beneath the bushes.

Remedies.-Hellebore is the best remedy for this pest. It may be applied as a dry powder, or in water-one ounce to three gallons. The bushes should be treated soon after the small holes appear in the lower leaves, and again about ten days later.

\section{The Currant Leaf-hopper.}

Empoa albopicta.

This is a small, pale-green insect, about one-tenth of an inch long, that occurs upon the under surfaces of the leaves of currants and gooseberries during May and June. They suck out the substance by means of their tiny beaks, which causes white spots to appear on the upper surface of the leaf (Fig. 44). This same insect also occurs upon a large number of other plants, sometimes being quite injurious to young apple trees. The adult is represented considerably magnified at Fig. 45, $a$, and the nymph at $b$ of the Fig. 44. Currant leat injured by Ieaf- $_{\text {boppers. }}$ same figure. The chief
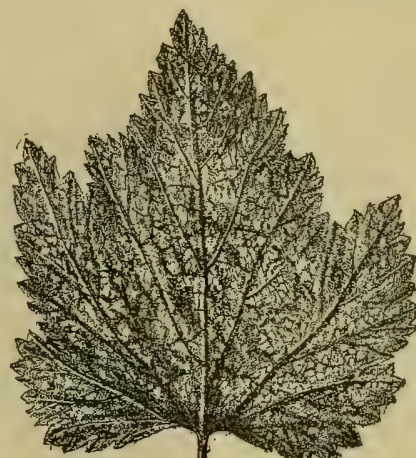
damage is done by the first brood, the insects 
leaving the bushes early in the summer, probably

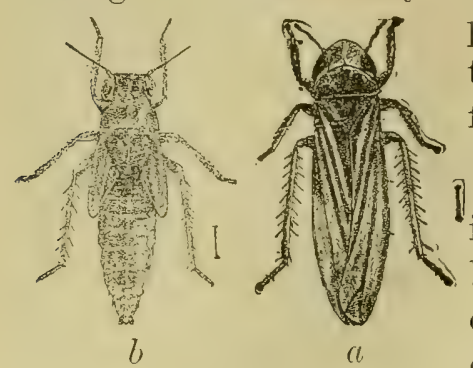

Fig. 45. Currant Leaf-hopper: $a$, adult : $b$, nymph. Magnified. preferring at this time the more succulent foliage of other plants.

Remedies, - Spraying or dusting infested bushes with pyrethrum, or insect powder, will destroy these little pests, provided it is done before they acquire wings. Tobacco powder is also said by many horticulturists to be an efficient remedy.

\section{The Currant Aphis.}

\section{Myzus ribis.}

This is a small, yellowish aphis that is found on the undersides of curled and blistered currant leaves early in summer. Such leaves are generally tinged with reddish above. The insects apparently migrate to some other plant during the summer, returning to the currant in autumn, and depositing small, black eggs upon the stems, especially about the buds.

Remedies.-On account of the deformed condition of the infested leaves, these insects are difficult to reach with insecticides. In garden patches the leaves attacked may be pulled off and dropped into a vessel holding water, with a film of kerosene on top. Spraying with kerosene emulsion quite early in 
the season, before the foliage has become conspicuously curled, would probably destroy a majority of the aphides then present upon the leaves.

\section{INJURING THE FRUIT.}

\section{The Gooseberry Fruit-worm.}

Dakruma convolutella.

The fruit of the gooseberry, and occasionally of the currant also, is often attacked by a small worm that eats out the substance, leaving only the skin. This is the progeny of an egg laid on the fruit when it was quite small by a spotted, pale gray moth. Soon after hatching from this egg the larva bores into the berry, and feeds upon the pulp. After it has eaten out one berry it fastens another to it by silken threads, and devours its contents, continuing the process until by the time it is fully grown it has formed a cluster of six or eight injured berries. At this time it is a pale-green caterpillar, three-fourths of an inch long, with a small, brown, horny-looking head. Shortly before the fruit ripens it lets itself to the ground by a silken thread, and, concealed among the fallen leaves and rubbish, spins a thin, silken cocoon within which it changes to a brown chrysalis. It remains in this condition until the following spring, when it comes forth as a moth : consequently there is only one brood of the larvæ each year. 
Remedies.-The fruit injured by these caterpillars is so conspicuous that hand-picking is a practical remedy. This must be done rapidly as the larvæ wriggle out of the cases and drop to the ground quickly when disturbed. If chickens are allowed to run over the ground after the fruit is gathered they will scratch up and devour many of the pupæ. So also will many be destroyed if the fallen leaves and rubbish are raked together and burned in autumn.

\section{Other Currant and Gooseberry Insects.}

There are a number of other insects that occasionally attack these fruits. The stems are sometimes infested by the Currant Bark-louse (Lecanium ribis) and the American Currant-borer (Psenocerus supernotatus); the leaves are attacked by the Currant Spanworm (Eufitchic ribearia) and various other caterpillars, as well as the Four-striped Plant-bug (Poecilocapsus lineatuis), and the fruit is liable to injury from various insects, especially the Currant Fruit-worm (Eupithecia interruptofasciata), the Currant Fly (Epochro canadensis) and the Gooseberry Midge (Cecidomyia grossularix). But these species are rarely sufficiently numerous to require special remedial treatment.

Summary of Treatment.-About the only regular treatment currants and gooseberries require is that of spraying or dusting with hellebore, soon after the leaves expand, to destroy the Imported Currant Worm. Stems which at that time show by their drooping foliage and weak appearance that they are probably infested by borers, should be cut and burned. 


\section{INSECTS AFFECTING THE RASPBERRY AND BLACKBERRY.}

\section{INJURING THE ROOTS.}

\section{The Raspberry Root-borer.}

Aegeria rubi.

The stems of raspberries and blackberries are sometimes injured by a whitish caterpillar with sixteen legs, that bores the root and base of the stem. This is the Raspberry Root-borer, and the caterpillar hatches from an egg deposited by a clear-winged moth upon the cane, a few inches above the soil surface. The larva, after hatching, eats into the center

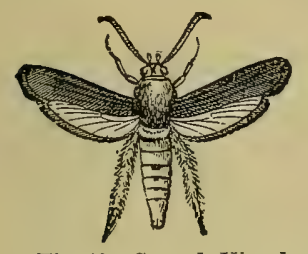

Fig: 46. Squash Vine-borer: larva and moth. of the stalk, where it devours the pith, working downward toward the root. It spends the winter in the root, feeding upon its substance, and in spring works upward again, generally in another cane than the one in which it descended. A few inches above the ground it gnaws almost through the stem-rvall, leaving the thin outer membrane intact. It then pupates inside the cane, near the partial opening. A short time later the pupa wriggles through the hole, bursting the outer membrane, and stops when about 
half way out. Then the skin splits open and the moth comes forth. An idea of the general appearance of the moth and larva may be obtained from Fig. 46, which represents a closely related insect, the Squash Vine-borer. Canes attacked by these borers often wither and die, and the injury is sometimes attributed to 'winter-killing.'

Remedies.-No other remedy than that of cutting out the larvæ, or pulling up and burning the infested canes has yet been discovered. Fortunately this insect is rarely sufficiently numerous to do serious injury. It occurs in wild as well as cultivated sorts.

\section{INJURING THE LEAVES.}

\section{The Raspberry Slug.}

Selandria rubi.

The Raspberry Slug, or Raspberry Saw-fly, is a four-winged black fly with a reddish abdomen, which deposits its eggs during spring in the raspberry leaf. The eggs soon hatch into small, whitish worms that feed upon the soft tissues of the tender foliage. In a few weeks they become full grown. They are then about three-fourths of an inch long, of a dark green color, and have the body thickly covered with spinose tubercles. The slugs now descend to the ground and construct rather firm cocoons slightly beneath the soil surface. They remain in these cocoons until the following spring, when they come forth as adult flies. 
Remedies.-These insects can easily be destroyed by dusting or spraying the infested bushes with powdered hellebore. In spraying, use from one-half to one pound of hellebore to fifty gallons of water.

\section{INJURING THE CANES.}

\section{The Raspberry Cane-borer.}

\section{Oberea bimaculata.}

The adult of this insect is a slender-bodied, black beetle, with a yellow collar just behind the head. It appears early in summer, usually during June in the Northern States, and deposits eggs in the green canes of raspberries and blackberries. The process of oviposition is peculiar : the beetle makes two transverse rows of punctures, about half an inch apart, in the cane, towards the tip, and midway betrreen these she deposits the egg. The rows of punctures make up a kind of girdling which causes the tip of the cane to wither. A short time after the egg is deposited, it hatches into a small cylindrical larva that bores downwards through the pith. By autumn they have frequently reached the bottom of the cane, where they change to pupæ, and the following June emerge again as beetles.

Remedies.-Soon after the canes are punctured by the beetle they wilt: consequently, if they are examined about midsummer, affected canes can easily be distinguished, and they should then be cut off below the lower ring of punctures, and burned. If 
the injury is noticed later, the whole cane should be pulled up and destroyed, to be sure to get the larva.

\section{The Snowy Tree Cricket.}

\section{Oecanthus niveus.}

Serious damage is frequently done in raspberry plantations by a small, white tree-cricket, which deposits its eggs in longitudinal rows in the green canes. One of these rows as it appears when the insect has completed its work is represented at Fig. 47, $a$, and the cane split open to show how the eggs are inserted is shown at $b$ of the same figure. At $c$ may be seen one of the elongated, slightly- $d$ curved, yellow eggs, considerably magnified, with an opaque, granulated cap at the upper end: $d$ is a more highly magnified view of this cap. The eggs hatch early in summer into young crickets bearing a general resemblance to the adults, though without wings. They feed upon plant-lice and other insects during their entire existence, being consequently in this way friends rather than foes of the fruit-grower. By the latter $\begin{gathered}\text { Fig. } 47 . \text { Eggs of Snowy } \\ \text { Tree-cricket: } a \text { egg punc- }\end{gathered}$ part of summer they become fully turess $b$, cane split open grown. They are then of a pale, nimien, $\begin{aligned} & \text { nagnified. } \\ & \text { mgg-cap, more }\end{aligned}$ 
whitish-green color, about four-fifths of an inch long, and of the form represented at Fig. 48. The female cricket deposits her eggs in the tender, growing canes of raspberries, blackberries, and grapes, and the twigs of maple, willow, catalpa, and several other species of trees. The injury thus done often causes the raspberries to die beyond the punctures, or else the damaged canes are broken off during the winter.

Remedies. - Trimming out and burning during fall or winter the canes containing the eggs is about the only practicable remedy known.

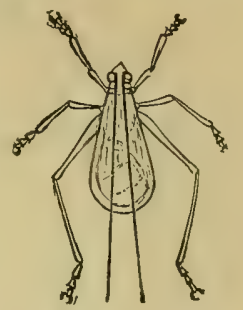

Fig. 48. Snowy Treecricket. Male.

\section{Other Raspberry and Blackberry Insects.}

Raspberries and blackberries are subject to attack by various insects besides those discussed in the foregoing pages. Certain galls are sometimes found upon the roots or stems, due when on the roots usually to the Raspberry-root Gall-fly (Rhodites radicum), and when on the canes to the Red-necked Agrilus (Agrilus ruficollis), or to the Blackberry Gall-fly (Diastrophus nebulosus). The foliage is sometimes eaten by various caterpillars or beetles, and the fruit is occasionally infested by the Flea-like Negrobug, or the Raspberry Span-worm (Synchlora rubiroraria). But these various insects as a rule only do an incidental injury, and are rarely sufficiently numerous to require special remedial treatment. 


\section{INSECTS AFFECTING THE GRAPE.}

\section{INJURING THE ROOT.}

\section{The Grape Root-borer.}

\section{Aegeria polistiformis.}

The roots of grapes are sometimes found to beattacked by a whitish, cylindrical caterpillar with sixteen legs, which bears a strong, general resemblance to the Peach-tree Borer. This is the insect named above. "When full grown," according to Dr. Riley, "the larva measures from an inch to an inch and three-quarters, and it then forms a pod-like cocoon of a gummy sort of silk, covered with little bits of wood bark and dirt. Within this cocoon it becomes a chrysalis which in due time, by aid of rows of minute teeth with which it is furnished, works its way out of the cocoon to the surface of the ground, and gives forth the moth. As with the Peach-borer, this insect requires a year to develop, and is founc in its different states of larva, chrysalis and moth, throughout the summer months, and it doubtless also passes the winter as a larva." The moth is a wasp-like creature, black, with bright, yellow bands across the abdomen.

Remedies.-This insect is rarely seriously injurious. When a vine shows by its weak or drooping appearance that it is suffering from an injury at the 
root, the earth should be dug away and the borers searched for, as is done with the Peach-borer. It has been suggested that mounding about the base of the vine with earth would prevent the deposition of eggs.

\section{The Grape Phylloxera.}

Phylloxera vastatrix.

The Grape Phylloxera is the worst insect enemy of the vineyardist. Its ravages have ruined thousands of acres of grapes in France and other European countries, and much damage has been done by it in

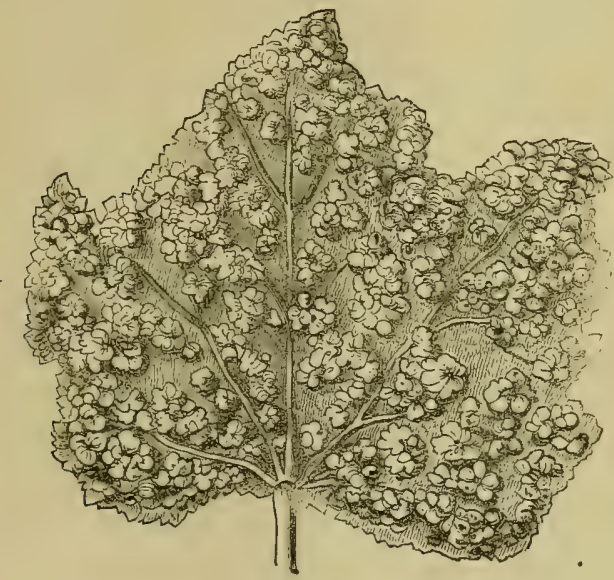

Fig. 49. Phylloxera galls on grape Ieaf.

America. There are two forms of it, one inhabiting the roots (represented in its various stages at Fig. 51), and one inhabiting the leaves (Fig. 50) upon which it forms minute galls (Fig. 49). 
Entomologists and horticulturists are indebted to Dr. C. V. Riley for the elucidation of the life-history of this curious insect, which, in his Seventh Report as State Entomologist of Missouri, he has summarized as follows: "It hibernates mostly as a young larva torpidly attached to the roots, and so deepened in color as generally to be of a dull brassy-brown, and, therefore, with difficulty perceived, as the roots are often of the same color. With the renewal of vine growth in the spring, this larva molts, rapidly increases in size, and soon commences laying eggs. These eggs in due time give birth to young, which soon become virginal, egg-laying mothers, like the first; and like them, always remain wingless. Five or six generations of these parthenogenetic, eggbearing, apterous mothers follow each other; when - about the middle of July, in this latitude-some of the individuals begin to acquire wings. These are all females, and, like the wingless mothers, they are parthenogenetic. Having issued from the ground, while in the pupa state, they rise in the air and spread to. new vineyards, where they deliver themselves of their issue in the form of eggs or egglike bodies-usually two or three in number, and not exceeding eight-and then perish. These eggs are of two sizes, the larger about 0.02 inch long, and the smaller about three-fifths of that length. In the course of a fortnight they produce the sexual individuals, the larger ones giving birth to females, the smaller to males. These sexual individuals are born 
for no other purpose than the reproduction of their kind, and are without means of flight, or of taking food, or excreting.

"They are quite active and couple readily, one male being capable, no doubt, of serving several females:
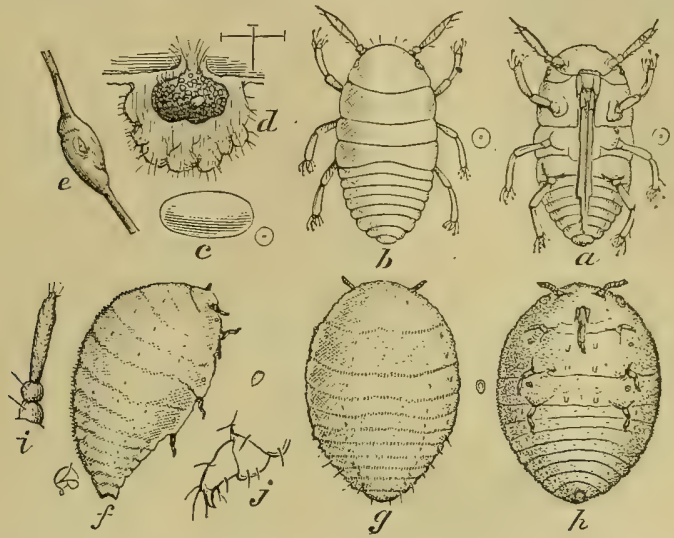

Fig. 50. Grape Phylloxera, leaf form: $a, b$, newly hatched nymphs, dorsal and ventral view; $c$, egg; $d$, section of gall; $e$, swelliug of tendril; $f, g, h$, mother of gall-louse, lateral, dorsal and ventral views; $i$, her antenna; $j$, two-jointed tarsus. Natural sizes indicated by small dots or figures.

the abdomen of the female, after impregnation, enlarges somewhat, and she is soon delivered of a solitary egg, which differs from the egg of the parthenogenetic mother only in becoming somewhat darker. This impregnated egg gives birth to a young louse which becomes a virginal, egg-bearing, wingless mother, and thus recommences the cycle of the species' evolution. But one of the most important discoveries of Bolbiana is that, during the latter part of the season, many of the wingless, hypogean mothers perform the very same function as the winged ones; 
$i . e .$, they lay a few eggs which are of two sizes and which produce males and females, organized and constructed precisely as those born of the winged females, and like them producing the solitary impregnated egg. Thus, the interesting fact is established that even the winged form is by no means essential to the perpetuation of the species; but that, if all such winged individuals were destroyed as fast as they issue from the ground, the species could go on multiplying in a vineyard from year to year. We have, therefore, the spectacle of an underground insect possessing the power of continued existence, even where confined to its subterranean retreats. It

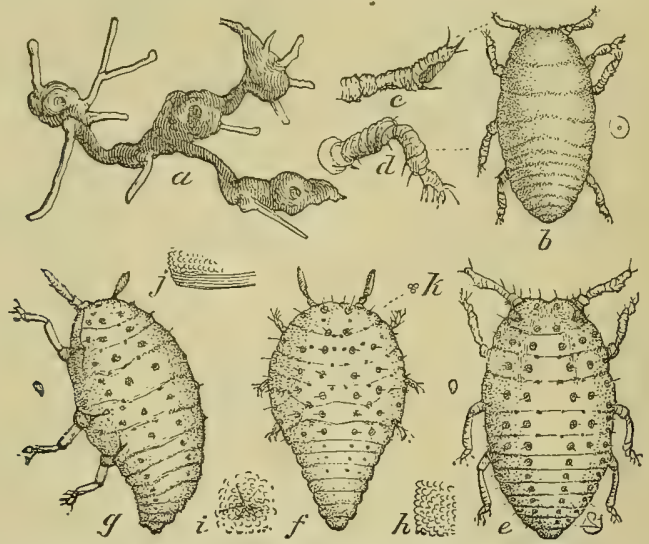

Fig. 51. Grape Phylloxera, root form: $a$, infested rootlets; $b$, hibernating larva; $c, d$, antenna and leg of same; $e, f, g$, more mature forms; $h$, granulations of skin; $i$, tubercle; $j$, transverse folds at border of joints; $k$, simple eyes.

sprears in the wingless state from vine to vine and from vineyard to vineyard, when these are adjacent, either through passages in the ground itself, or over 
the surface. At the same time it is able, in the winged condition, to migrate to more distant points. The winged females, as before stated, begin to appear in July, and continue to issue from the ground until vine growth ceases in the fall. Yet they are much more abundant in August than during any other month, and on certain days may be saia to literally swarm. Every piece of a root a few inches long, and having rootlets, taken from an infested vine at this season, will present a goodly proportion of pupæ; and an ordinary quart preserve jar, filled with such roots and tightly closed, will furnish daily, for two or three weeks, a dozen or more of the winged females, which gather on the sides of the jar toward the light. We may get some idea, from this fact, of the immense numbers that disappear through the air to new fields, from a single acre of infested vines, in the course of the late summer and fall months. If to the above account we add that occasionally individuals abandon their normal underground habit, and form galls upon the leaves of certain varieties of grape-vine we have, in a general way, the whole natural history of the species."

Remedies.-In America comparatively little has been done in a practical way in fighting this insect, because its injuries here are usually not serious. But in Europe a great deal has been accomplished in preventing its injuries. According to Dr. Riley the means employed there " consist in (1) methods which avoid the necessity of direct treatment, comprising 
the use of American stocks and planting in sandy soils; (2) the employment of insecticides (bisulphide of carbon, sulphocarbonate of potassium, and the kerosene emulsion); and (3) submersion."

\section{INJURING THE LEAVES.}

\section{The Grape-vine Flea-beetle.}

\section{Graptodera chalybea.}

This is a small, steel-blue beetle (Fig. 52, $d$ ) that is often very destructive to grape-vines. It hibernates as an adult. As soon in spring as the buds begin to swell the beetles come forth and attack them.

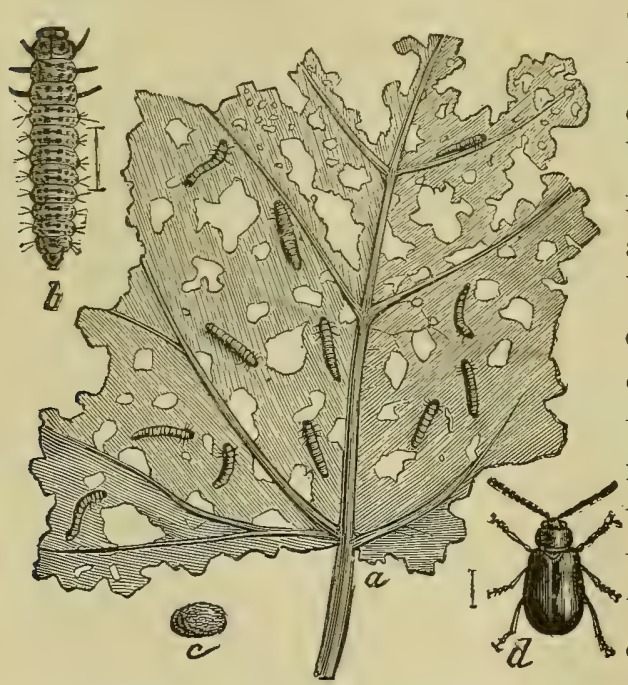

Fig. 52. Grape-vine Flea-beetle: $a$, leaf infested by larva ; $b$, larva, magnified; $c$, cocoon; $d$, beetle, magnified.

The injury at this time is often great, because the immature leaf and flower buds are so easily destroyed. The beetles continue feeding for three or four weeks, during the latter part of the time depositing small orange-yellow eggs in clusters on the under sides of the leaves. 
They then die, and in a ferw days the eggs hatch into small, dark-colored larvæ that feed upon the foliage. As they grow older they gnaw irregular holes in the leaves, giving them a ragged and unsightly appearance (Fig. 52,a). When fully grown (three or four weeks after hatching) they are about three-tenths of an inch long, brown in color, with six legs, and four or five black dots on the back of 'each ring or segment of the body. The head is black, and there are numerous hairs on the body. One is shown somewhat magnified at $b$, Fig. 52. When fully grown the larvæ leave the vines, and, entering the soil, form earthen cocoons $(c)$, within which they change to pupæ. A few weeks later they again transform and emerge as perfect beetles. These also feed upon the foliage and lay eggs for a second brood of larvæ.

Remedies.—Spraying with Paris green (3 ounces to 50 gallons water) is probably the best remedy for this pest. They may also be destroyed by pyrethrum or insect powder. On cool mornings the beetles are quite sluggish, and may be collected by jarring them on sheets.

\section{The Rose Chafer.}

\section{Macrodactylus subspinosus.}

This insect has been known for nearly a century as a serious enemy of the horticulturist. It is distributed over a large portion of the United States, but appears to be injurious only in certain localities where areas of low, sandy bottom-lands offer unusual 
opportunities for it to multiply. It feeds in the beetle state upon a very great variety of trees and plants, often being exceedingly injurious to the flowers or foliage of apples, pears, plums, peaches, roses, raspberries, blackberries, grapes, and other plants.

The adult Rose Chafer, Rose Beetle or Rose Bug, is a hard, brown insect, not quite half an inch long, of the form represented at Fig. 53.c. It makes its. appearance early in summer, about the time grapes come into blossom, and

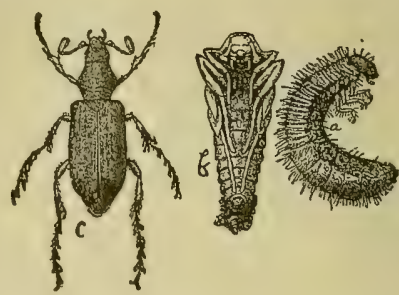

Fig. 53. Rose Chafer: $a$, larva;. $b$, pupa; $c$, beetle. Slightly magnified.
pig. feeds upon the flowers, foliage or fruit of the plants alreary mentioned. After pairing, the females, deposit thirty or more eggs an inch or so beneath the soil surface, preferring for this purpose, according to Dr. Riley's observations, 'low, open meadow land or cultivated fields, particularly where the soil is light and sandy.' In two or three weeks the eggs hatch into grubs that feed upon the roots of grass, and possibly other plants, and become fully grown $(a)$ in autumn. As winter approaches they go deeper into the soil, coming to the surface again in spring, and making for themselves rude, earthen cells in which they change to the pupa state $(b)$. Three or four weeks later they again change, and the perfect beetle comes forth. Thus there is but one brood a year. The insect lives in the beetle state about a month. 
Remedies.-There is, perhaps, no fruit insect so difficult to combat as this. As yet no practicable method of destroying it in its breeding grounds has been found, and the success attending the various preventives of beetle injury has been by no means universal. Spraying or dusting with pyrethrum or insect powder has been found to stupefy the beetles temporarily, and will occasionally prove useful in protecting fruits. A single rose-bush or grape-vine may be covered with mosquito netting, but of course this is impracticable on a large scale. Thorough spraying of grape-vines and fruit-trees with a wash made by adding three or four pecks of freshly slaked lime, and a quart of crude carbolic acid to 50 gallons of water, has been reported by several extensive fruit growers, who have tried it on a large scale, to be entirely successful, although on the other hand some who have tried it in a smaller way say it did little or no good. For the commercial fruit-grower, however, this seems the most promising remedy. In parts of New Jersey, hand-picking has been resorted to as the only sure method of extermination, the insects being collected in the cooler hours of the day.

\section{The Spotted Grape-vine Beetle.}

\section{Pelidnota punctata.}

This insect has been known for years to attack grape-vines, but it has rarely been reported to do really serious injury to them, probably because it usually is present in such limited numbers that its 
depredations are insignificant. The larva (Fig. 54, a) feeds on the decaying roots of various trees, and resembles somewhat the common white grub of meadows-the larva of the May Beetle. Its general color is whitish, with the head c hestnut brown. It is supposed to. require three year's to complete its dev el o p ment. When fullgrownitforms a sort of cocoon, within wh i c h it

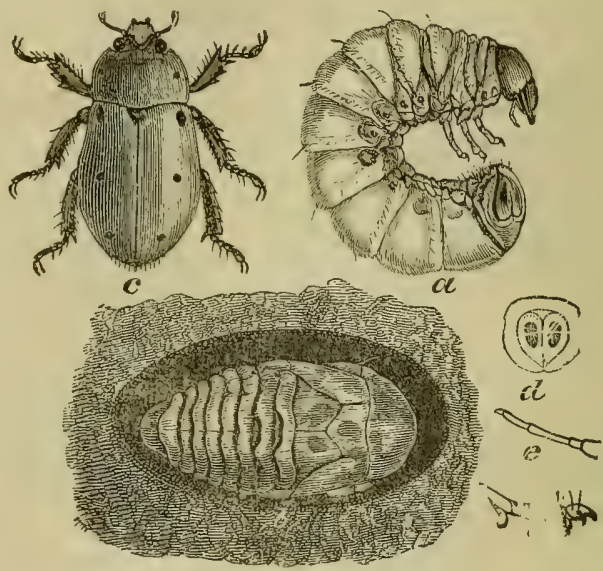

Fig. 54. Spotted Grape-rine Beetle: $a$, larva ;

changes to the chrysalis or pupa state, to emerge about a fortnight later as an adult beetle.

The general color of the upper surface of the beetle is a dull yellowish brown, but the thorax is darker, and somerwhat bronzed; and the under surface is of a brilliant metallic greenish-black hue. There are three distinct black dots on each of the wing covers, and also one on each side of the thorax. The beetle usually feeds upon the foliage of wild and cultivated grape-vines, and also on the Virginia Creeper; but sometimes attacks green grapes, biting holes through the skin, and so ruining the fruit. 
Remedies.-The only practical remedy so far proposed is that of collecting the beetles by hand and destroying them. As they fly especially just at dusk, this is the best time for accomplishing the work.

\section{Grape Sphinx Moths.}

The grape forms the favorite food of several species of large and handsome sphinx moths. As there is not space to discuss each of these, we will take the Achemon Sphinx (Philampelus achemon) as an example. The adult of this species (Fig. 55) is one of the

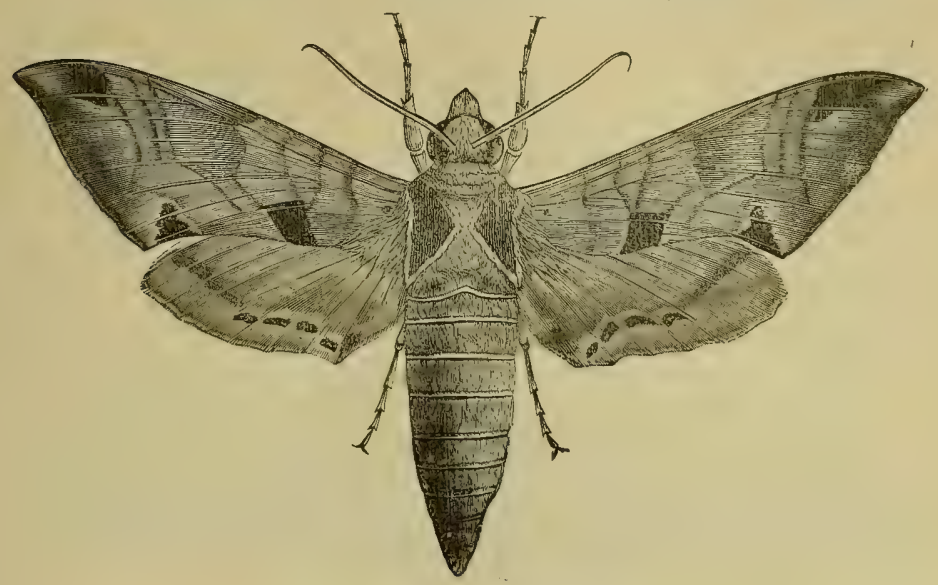

Fig. 55. The Achemon Sphinx.

most beautiful of the hawk moths. It measures three and a half inches across its expanded wings, and is brownish-gray in color, with lighter brown variegations and deeper brown spots arranged on the front wings, as shown in the figure. The posterior wings are pink, more reddish toward the middle, 
and having a wide grayish border along the hind margin, on the front edge of which is a row of dark spots. These moths make their appearance during June and July, flying about grape-vines and various

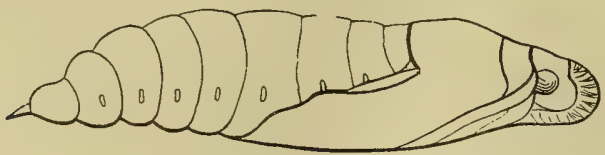

Fig. 56. Pupa of Achemon Sphinx.

flowers at dusk, and depositing their eggs on the under sides of the leaves of grape and Virginia Creeper. Within a few days these eggs hatch into little larvæ that feed upon the foliage, growing so rapidly that by September they are nearly four inches long, and as thick as a man's finger (Fig. 57). At this time different individuals vary greatly in color, some being straw-yellow and others reddish-brown. There are six cream-colored spots along the sides, and numerous little dots scattered over the body. The head

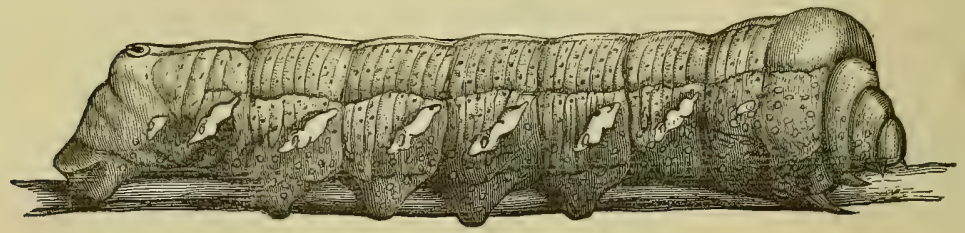

Fig. 57. Larva of Achemon Sphinx.

and first two body segments are smaller than the rest, allowing the caterpillar to draw them partially inside the next one back.

The fully-grown caterpillar descends to the ground, and entering the soil several inches forms a smooth oval cell, within which it changes to a dark, shining 
brown pupa or chrysalis (Fig. 56). It remains in this condition until the following year, when it emerges as a moth again.

The Green Grape-vine Sphinx (Darapsa myron) and the Pandorus Sphinx (Philampelus pandorus) are closely related to the Achemon Sphinx, and similar to it in life-history and habits. All three species are subject to the attacks of a small parasitic fly, that spins oval cocoons Fig. 58. Caterpillar with Cocoons of Parasite. upon the backs of the Adult Parasite at right. Latter magnified. caterpillars, as shown at Fig. 58, which represents the larva of the Green Grape-vine Sphinx so infested. The life-history of these little creatures has already been described in the Introduction (page 15).

Remedies.-Fortunately these sphinx larvæ seldom become sufficiently numerous to do serious injury. They are so conspicuous both on account of their size and the defoliated condition of the branches upon which they are at work, that hand-picking is usually a sufficiently simple and practical remedy.

\section{The Abbot Sphinx.}

\section{Thyreus abbotii.}

This is a comparatively rare species, and has never been known to do serious injury in vineyards. The moth (Fig. 59), a handsome, chocolate-brown insect, measuring two and a half inches across the expanded 
wings, appears in spring, and deposits eggs upon the grape-vines. The larva soon hatches, and feeds upon the leaves, becoming fully grown during the latter part of summer. It is then about two and a half

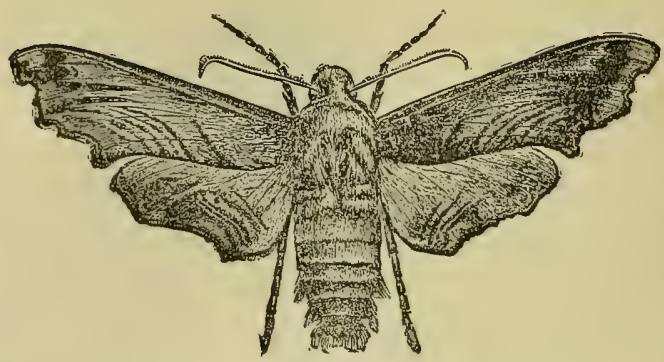

Fig. 59. Abbot Sphinx: larva and moth.

inches long, yellowish or reddish-brown in color, and of the form represented in the upper illustration of Fig. 59. It now descends to the ground, where it forms a loose cocoon, within which it changes to the chrysalis state, remaining in that condition until the following spring, when it emerges as a moth again.

Remedies.-Unless this insect becomes much more numerous than it has been heretofore, it can easily be held in check by a little hand-picking.

\section{The Grape-vine Leaf-hopper.}

\section{Typlocyba vitis.}

This little insect is frequently called the Grape Thrips, but its more proper name is the one given 
above, as it is not a thrips at all, but a true leafhopper. It is a beautiful little creature, about onetenth of an inch long, yellow with bright red markings, and of the form represented at Plate III, Fig. 5 (p. 84). "They make their first appearance," says Dr. Harris, "on the leaves in June, when they are very small and not provided with wings, being then . in the larva state. During most of the time they remain perfectly quiet with their beaks thrust into the leaves, from which they derive their nourishment by suction. If disturbed, however, they leap from one leaf to another with great agility. As they increase in size they have occasion frequently to change their skins, and great numbers of their empty castskins, of a white color, will be found throughout the summer adhering to the under sides of the leaves, and upon the ground beneath the vines. When arrived at maturity, which generally occurs during the month of August, they are still more agile than before, making use of their delicate wings as well as their legs in their motions from place to place; and when the leaves are agitated they leap and fly from them in swarms, but soon alight and begin again their destructive operations. The infested leaves at length become yellow, sickly, and prematurely dry, and give to the vine at midsummer the aspect it naturally assumes on the approach of winter. In autumn the leaf-hoppers desert the vines, and retire for shelter during the coming winter beneath fallen leaves, and among the decayed tufts and roots of 
grass, where they remain till the following spring, when they emerge from their winter quarters, deposit their eggs upon the leaves of the vine, and perish."

Remedies.-If the vines are dusted early in the season, before the leaf-hoppers have acquired wings, with pyrethrum (insect powder) or tobacco dust, by means of some apparatus like Leggett's powder gun, the pests will be destroyed by the million. This appears to be the most promising remedy for them. Some vineyardists catch them on a sheet, saturated with kerosene or coverer with tar, the sheet being stretched on a frame which is carried along one side of the row, while somebody goes along the other side of the vines and frightens the insects toward it.

\section{The Grape-vine Leaf-roller.}

Desmia maculalis.

This is a slender, somewhat flattened, yellowishgreen caterpillar, measuring when full grown about three-quarters of an inch, that rolls the leaves of grape-vines, fastening the sides together by silken threads. It hatches from an egg laid on the leaf by a pretty little dark-brown moth, expanding nearly an inch, and having several conspicuous white spots on its wings. The larva usually pupates within the folded leaf. There are two broods each season, the first brood of larvæ pupating about midsummer, to emerge as moths shortly afterwards, and the second pupating in autımn and hibernating as chrysalids. 
Remedies.-This insect is seldom sufficiently numerous to require remedial treatment. The larvæ may be crushed within their cases, or the cases picked off and burned late in autumn, before the leaves fall off, if they threaten to become seriously destructive.

\section{The Beautiful Wood-nymph.}

Eudryas grata.

This is a very handsome insect, both in its immature and adult stages. The moth (Fig. 60,g) meas-

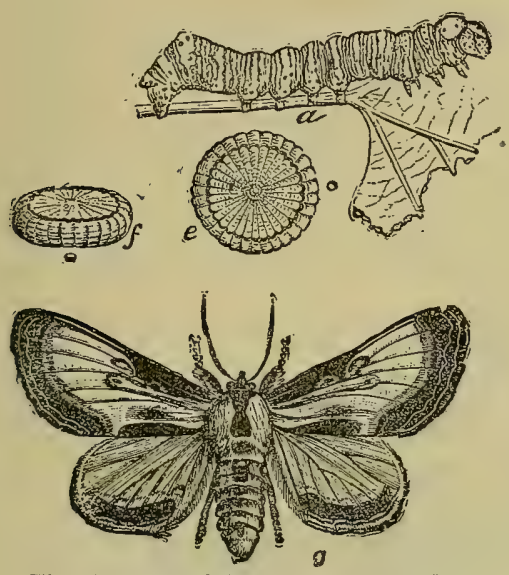

Fig. 60. Beautiful Wood-nymph: $a$, larva; $e, \boldsymbol{f}$, egg, magnified; $\boldsymbol{g}$, moth.

ures nearly two inches across its expanded front wings, which are of a glossy creamy - white color, beautifully marked with purple, brown and green. It lays its eggs $(e, f)$ on the under side of the leaves. The larvæ soon hatch and feed upon the foliage. developing rapidly, so that by the latter part of summer they are full grown $(\alpha)$, the body being of a pale bluish color, crossed by bands and lines of orange and black. The larvæ now leave the vine and seek some concealed situation in which to pupate. They pass the winter in the chrysalis state, and emerge the following spring as moths. 
Remedies.-This insect is rarely injurious, probably because it is kept in check by certain parasites. It can be destroyed, if it should become too numerous, by hand picking, or by spraying or dusting the infested vines with pyrethrum or hellebore.

\section{INJURING THE FRUIT.}

\section{The Grape-berry Moth.}

Eudemis botrana.

Grapes are frequently injured by having their substance eaten out by a small, whitish worm that fastens three or four berries together with silken threads, and devours the contents of each. This insect is the larva or caterpillar of the Grape-berry Moth, a species imported many years ago from Europe, where it has long been known as an enemy of the vine. The adult is a small, bluish moth, that deposits its eggs late in June or early in July. The

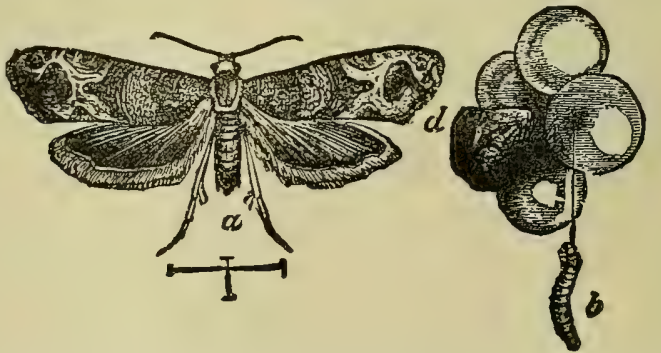

Fig. 61. Grape-berry Motb : $a$, moth; $b$, larva; $d$, injured fruit.

very young caterpillar is found within the skin of the grape, devouring the contents. When it has 
finished one it gnaws its way out and enters a neighboring berry, fastening the two together with silken threads (Fig. 61, d). In this way three or four berries are frequently destroyed by a single larva, which, when fully grown, is about a quarter of an inch long, of a dull green color tinged with red, and covered with a few short hairs. It pupates on the leaf, first cutting out a crescent-shaped flap which it binds down by means of silken threads, forming a snug, tight cocoon. About a fortnight later, in southern latitudes, the moths appear, to lay eggs for a second brood, which hibernates in the pupa state.

Remedies. - The only remedies as yet suggested are those of gathering and burning the fallen leaves in autumn or early winter, or picking and burning injured fruit, being sure to get the larva with it.

\section{Other Grape Insects.}

The grape is subject to attack by many insects besides those discussed in the preceding pages. The roots are sometimes bored by the gigantic larvæ of two species of Prionus-the Broad-necked Prionus (P. laticollis) and the Tile-horned Prionus (P. imbricornis), but these insects usually infest only grapevines planted on new land, and are seldom injurious in older fields. The branches are attacked by a variety of species, including certain tree-hoppers, the Maple Bark-louse, the Red-shouldered Sinoxylon ( $S$. basilare), and certain gall-making insects. The enemies to the foliage of the grape are legion, and 
include insects of varied habits and natural orders. The fruit is sometimes injured by the larva of a small snout-beetle, called the Grape Curculio (Craponius inxqulis), and also by a very minute larva that occurs inside the seed, the Grape-seed Maggot (Isosoma vitis). But these insects are seldom really injurious.

Summary of Treatment.-The grape is subject to attack by so great a variety of insect enemies that it is difficult to give any general directions for the season's treatment. It must largely be regulated according to the insects present. Clean culture, however, is always advisable, as it lessens the opportunities for many species to survive the winter successfully.

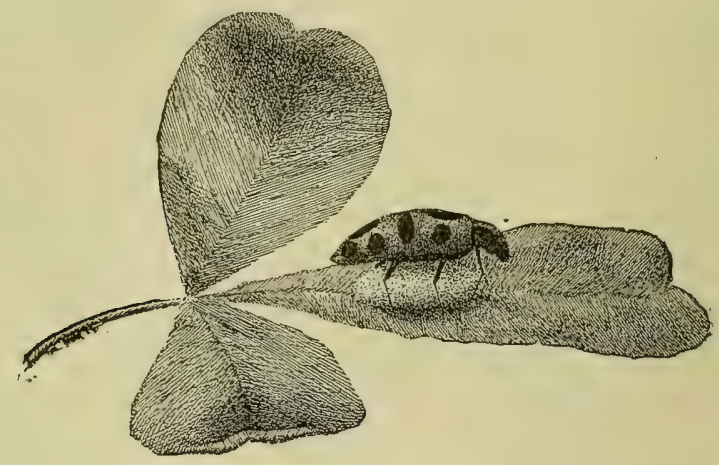




\section{PART III.}

\section{INSECTS AFFECTING SHADE TREES, ORNAMENTAL PLANTS, AND FLOWERS.}




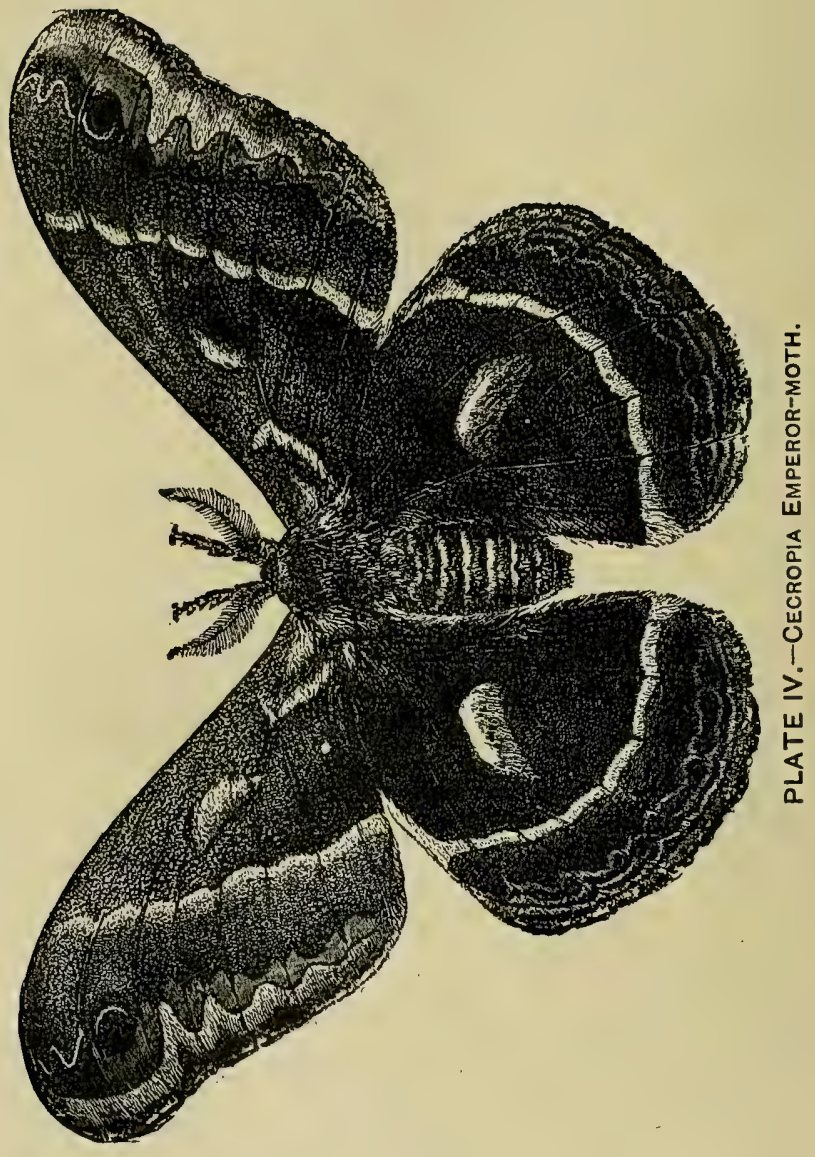




\section{INSECTS AFFECTING SHADE TREES.}

\section{INJURING THE LEAVES.}

\section{The Cecropia Emperor-moth.}

Platysamia cecropia.

People are often puzzled during winter over large, peculiar, grayish-brown cocoons (Fig. 63) that occur not infrequently on the limbs of maple, apple, pear, cherry, and a great variety of fruit and shade trees.

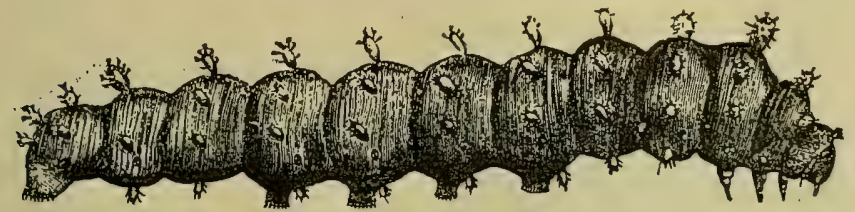

Fig. 62. Cecropia Caterpillar.

These are the cocoons of one of the largest and handsomest American insects-the Cecropia Emperormoth, illustrated, natural size, at Plate IV. This moth often measures six or seven inches across the front wings, the ground color of all the wings being a grizzled, dusky brown, with the hind margins clay colored; near the middle of each wing there is an opaque, kidney-shaped, dull red spot, having a white center, and a narrow, black edging, and beyond the spot there is a wavy, reddish band bordered internally with white. The fore-wings, next to the shoulders, are dull red with a curved, white band, and near 
the tips of the same is an eye-like black spot within a bluish-white crescent. The upper sides of the body and the legs are reddish; the fore part of the

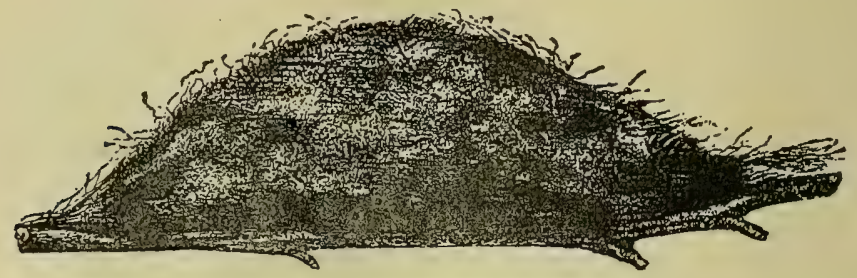

Fig. 63. Cocoon of Cecropia Moth.

thorax, and the hinder edges of the rings of the abdomen are white; the under surface of the body is checkered with red and white.

The moths come forth from the cocoons in June

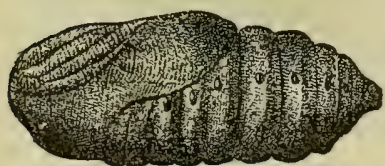

Fig. 64. Cecropia Pupa. and deposit their eggs on the various kinds of trees upon which the larvæ live. About a week later the eggs hatch into small, spiny caterpillars, that devour the foliage and rapidly increase in size. They are very voracious, and reach maturity late in summer. They are then (Fig. 62) often over three inches long, as thick as a man's thumb, and have, along the back, rows of large, coralred tubercles. Early in autumn they spin their silken cocoons, within which they change to dark brown pupæ (Fig. 64), remaining in this condition until the following summer, when they come forth as moths to lay eggs for another brood. 
There are several species of parasites that prey upon the Cecropia caterpillars. On this account they only occasionally become injurious.

Remedies.-By spraying with the arsenites, or hand-picking the larvæ or cocoons, this insect may be easily checked when it threatens to become destructive.

\section{The White-marked Tussock-moth.}

\section{Orgyia leucostigma.}

This insect is one of the most destructive leaf-eating caterpillars, and during recent years has done much damage in many cities and villages. The larva feeds upon the foliage of a great variety us fruit and shade trees.

If the trunks or larger limbs of maple, apple, elm, or any other of the trees infested by this insect, be examined any time in autumn or winter, after the leaves have fallen, one may find scattered here and there upon the bark thin gray cocoons, many of which will be covered with large bunches of spherical white eggs, fastened together by a protecting

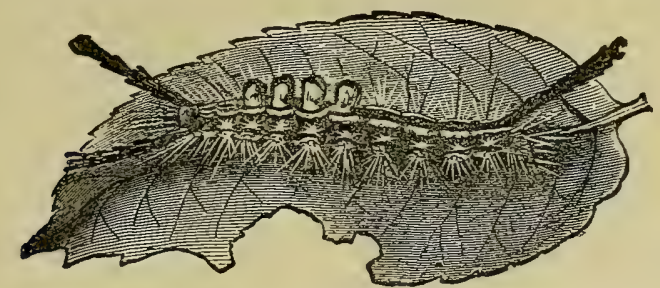

Fig. 65. Caterpillar of White-marked Tussock-moth.

froth-like mass. In May, soon after the leaves come out, these eggs hatch into small caterpillars, which 
at once begin eating the foliage about them. They continue to devour it for six or seven weeks, when they become full-grown. They are then very handsome (Fig. 65) and measure a little over an inch. The general color is bright yellow. The head and two tubercle-like projections on the hinder portion of the back are of a bright, coral-red. 'There are four cream-colored tufts of hair along the back. Two long black plumes project forward from just behind the sides of the head, and another projects backward from the posterior end of the body. About the middle of July the eaterpillars spin thin, whitish cocoons upon the rougher bark, and about a fortnight
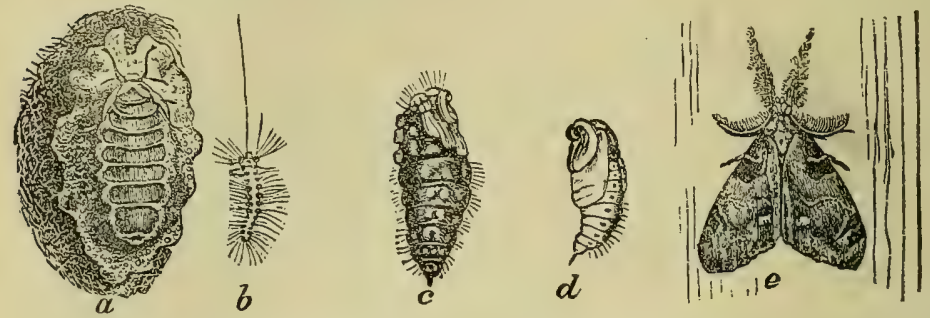

Fig. 66. White marked Tussock-moth : $a$, female moth on cocoon; $b$, young larva hanging by thread; $c$, female pupa; $d$, male pupa ; $e$, male moth.

later come forth as moths. These lay eggs for a second brood, which completes its transformations before winter sets in. The pupa of the female (Fig. $66, c)$ is larger than that of the male $(d)$. The male moth differs greatly from the female moth, the former being winged (Fig. 66,e), while the latter is wingless $(a)$. The female crawls upon the top of the cocoon $(a)$ as soon as she emerges from the pupa 
state, where, after mating with the male, she deposits her eggs in a single mass and dies.

Remedies.-The increase of this insect is greatly checked by several parasitic enemies, nearly a dozen species of two-winged and four-winged flies being known to prey upon it. The caterpillars may be destroyed by spraying the infested trees with the arsenites-Paris green or Lordon purple; or the egg masses may be picked off the bark in winter.

\section{The Fall Web-worm.}

\section{Hyphantria cunea.}

The work of fow insects is more universally known than that of the Fall Web-worm. Late in summer and early in autumn the conspicuous, unsightly webs of this pest may be seen in nearly every orchard and hedgerow over a large portion of the United States. $\mathrm{Th}$ e adult is a pretty, white moth (Fig. 67, c), which deposits eggs on the leaves of various trees early in summer. These
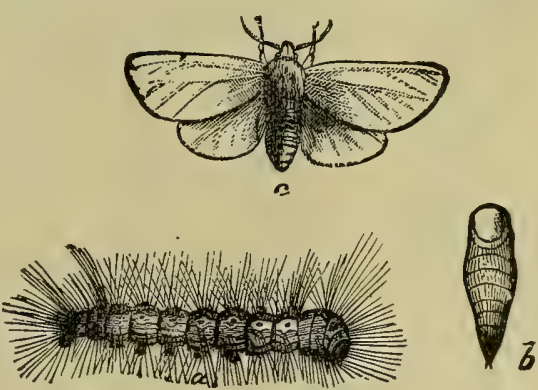

Fig. 67. Fall Web-Trorm: $a$, larva; $b$, pupa; $c$, moth.

soon hatch into young caterpillars that begin at once to spin a protective web. The young worms are of a pale-yellow color, sparsely covered with hairs, and have a black head and two rows of black marks 
upon the body. They feed upon the parenchyma of the foliage, leaving the network of veins, and grow quite rapidly, enlarging the web as they develop. By the time they are full grown a single lot of them will destroy the foliage of a good-sized branch, making it very conspicuous on account of the web-like covering. At this time the larvæ are a little more than an inch long $(a)$, with the body densely clothed with yellowish hairs. They now leave their nests and descend to the ground, where just beneath the surface, or under some suitable shelter above the surface, they spin slight, silken cocoons within which they change to the chrysalis state. At the North there is but one brood each year, but in the Southern States there are two.

Remedies. The webs of this insect are so conspicuous that it is an easy matter to cut them off and burn or crush the larvæ. This is a simple remedy, and the earlier it is done the better. The pest may also be destroyed by spraying with London purple or Paris green when the larvæ are young.

\section{The Imported Elm Leaf-beetle.}

\section{Galeruca xanthomelæna.}

During recent years this insect has been exceedingly destructive in many cities of the Eastern States to that loveliest of shade trees-the elm. It has long been known in the Old World, having been especially injurious in France and Germany, and is supposed to have been imported into America 
during the early part of the present century. Theeggs (Fig. 68, a, ) are laid on the under side of the. leaf in two or three rows, each group consisting of from five to twenty eggs. At $e$ in the figure they are shown considerably magnified, and as will be seen they are very close together, and fastened securely to the leaf. In about a week the larvæ hatch and begin eating the leaves, causing them to look as if riddled with fine s h o t. They Fig. 68. Elm Leaf-beetle: $a$, eggs; $b$, larvæ; $c$, beetle; become fully

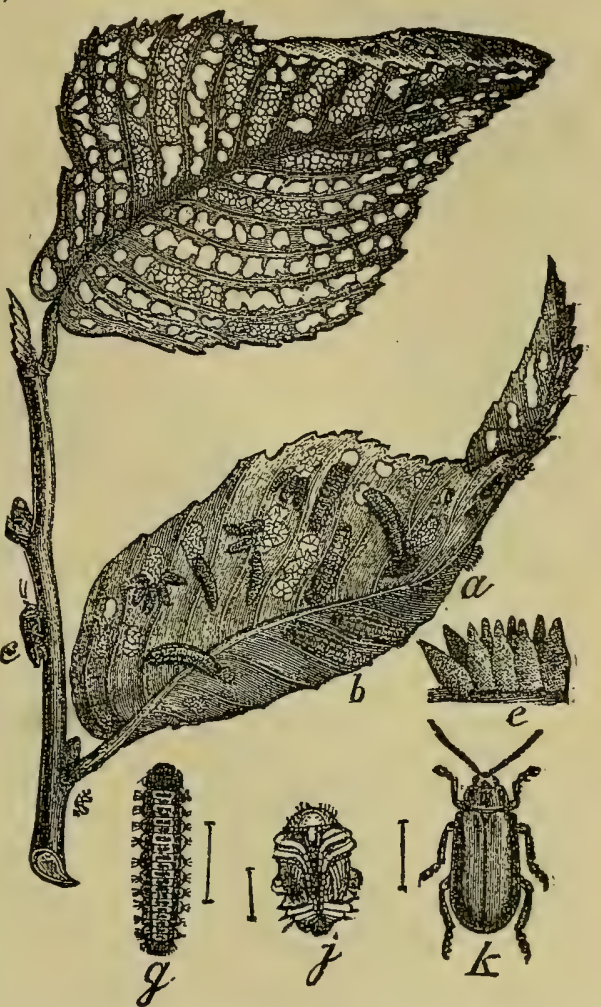
grown $(g)$ in two or three weeks, when they descend to the ground, and, finding some convenient shelter, change to pupæe $(j)$. Ten days later the perfect beetles ( $c$, natural size; $k$, magnified,) come forth and eat the leaves, although the damage done by the- 
insect in this beetle state is much less than that done by the young, growing larvæ. "There are three or four broods each season, and the beetles pass the winter in whatever shelter they can find, especially congregating in hollow trees, and under old leaves.

Remedies.-This pest can be held in check by spraying with London purple or Paris green (4 ozs. to 50 gals. water). The application should be made when the eggs are being laid, in order to kill the larvæ before they have done any damage. The addition of a little flour to the poison mixture seems to render it more effective. To reach the tops of high trees a pump of considerable power is required. Gould's Double-acting Garden or Fire Engine seems to be especially adapted for this purpose.

\section{The Bag-worm.}

Thyridoptery. ephemeræformis.

The twigs of various deciduous and coniferous trees are often infested during the winter months by small bags or sacs (of the form shown at Fig. 69,e) suspended to the leaves or branches. If one of the larger of these bags be cut open, there will be found within it a brown, membranous shell (the pupa case of the moth) filled with many small, yellow eggs (e). In this condition the Bag-worm or Basket-worm passes the winter. Late in spring the larvæ hatch, and at once form little cases of fragments of leaves fastened together by silken threads. Beneath these .cases $(g)$ they feed upon the foliage, enlarging them as 
the larvæ develop, and during later life using bits of twigs or stems in their construction, instead of leaf particles. The full-grown larva is represented in its. bag at $f$, and without it at $a$. When fully developed the worms descend to the earth by means of silken. threads, and crawl about until they reach the bases of other trees, which they ascend. This is the way the species migrates. The larvæ pupate within the cases, and about three weeks later change to moths.

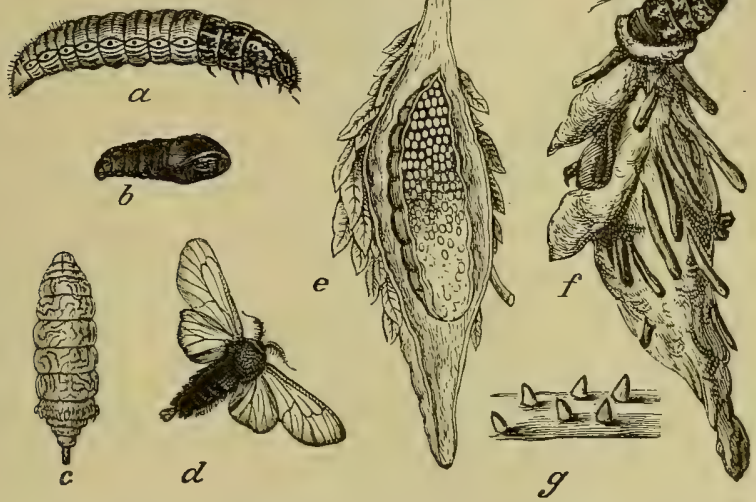

Fig. 69. Bag-worm : $\alpha$, larva; $b$, male pupa; $c$, female moth; $d$, male moth; $e$, bag and pupa case cut open to show eggs; $f$, full-grown larva with bag; $g$, young larvæ with their conical coverings.

The two sexes of the moths differ greatly, the male. (d) having well developed wings, while the female (c) is wingless. The latter deposits her eggs in the empty pupa case from which she has emerged, and falls to the ground, where soon afterward she dies.

The Bag-worm feeds upon a great variety of trees, and apparently prefers coniferous to deciduous sorts. 
Red Cedar and Arbor Vitæ are especially subject to attack. Its injuries are sometimes very severe on shade trees in city streets and public parks. There are several parasitic insects that prey upon the larvæ.

Remedies.-The simplest remedy for this insect is that of spraying with London purple or Paris green. This should be done in early summer when the worms are young. Effective work also can be done, according to Dr. Riley, "during the winter time or when the trees are bare. The bags which contain the hibernating eggs, and which are very easily detected then, may be gathered or pruned and burned. This work may be so easily done that there is no excuse for the increase of this species. Where intelligent action is possible, the bags were better collected and heaped together in some open enclosure away from trees, rather than burned. By this means most of the parasites will in time escape, while the young Bag-worms, which will in time hatch, and which have feeble traveling power, must needs perish from inability to reach proper food."

\section{The Green-striped Maple-worm.}

\section{Anisota rubicunda.}

In many Western States maple trees are regularly defoliated by a large caterpillar, alternately striped with light yellowish-green and dark-green, having two long, black horns on the second segment behind the head, and other similar but shorter horns on the posterior segments (Fig. 70, a). This is the Green- 
striped Maple-worm. It is the larva of a handsome. yellowish-pink moth $(c)$, sometimes called the Rosy Dryocampa. These moths appear early in summer,

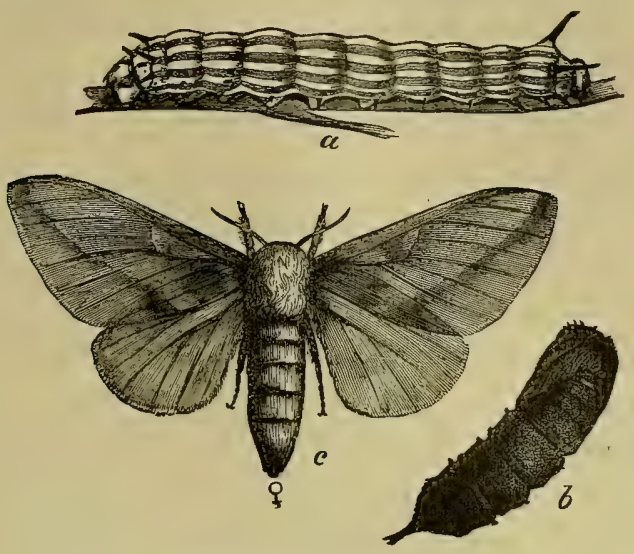

Fig. 70. Green-striped Maple-worm: $a$, larva; $b$, pupa ; $c$, moth.

and lay their eggs on the under sides of the maple leaves in clusters varying from forty to eighty each. The larvæ hatch in a week or ten days, and feed upon the foliage, being gregarious at first, but gradually spreading as they grow older. In a few weeks they become fully developed as larvæ, having moulted four times, when they descend to the ground, where, just beneath the soil surface, they change to dark-brown pupæ (b). About a fortnight later they come forth as moths again. These moths, which usually appear during July or August, lay eggs for a second brood of larvæ that develop during late summer or early autumn, and pass the winter as pupæ, emerging as moths the following summer. 
The second brood of larvæ are much more numerous, and consequently more destructive, than the first. Although maple forms the favorite food-plant of the insect, it is occasionally found upon oaks and a few other trees. The larvæ are preyed upon by various. insectivorous birds, and by several insect parasites.

Remedies.-Spraying with London purple or Paris green early in the season, just after the worms hatch, is the most effective remedy for this insect.

\section{The Walnut Caterpillar.}

\section{Datana angusii.}

The leaves of walnut and butternut trees are frequently eaten during summer by a large, blackish caterpillar. This is the larva of a good-sized moth that makes its appearance from the middle of June to the first of July, and deposits its eggs, seventy to a hundred in a place, on the under surface of the

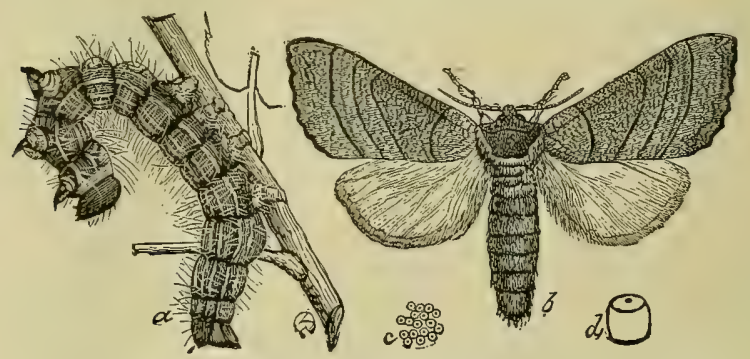

Fig. 71. Yellow-necked Apple-worm: $a$, larva; $b$, moth; $c$, eggsall natural size; $d$, egg, magnified.

leaves. In a short time the larvæ hatch, and begin feeding upon the foliage. They increase rapidly in size, and in a few weeks attract attention on account 
of the defoliated twigs where they have been at work. They are gregarious in habit, and at the times of moulting, or casting of the skin, they migrate in a body to the trunk of the tree, frequently descending. nearly to its base, and, piling themselves rne upon another, remain in a solid mass until the process is: completed. Then they crawl back to the twigs and begin feeding again. When fully grown as caterpillars, they go to the ground and change to the pupa state, just beneath the soil surface. Here they remain until early the following summer, when they emerge as moths to lay eggs for another brood.

A fair idea of the appearance of the Walnut Caterpillar and its moth may be obtained from Fig. 71, which represents a closely-related insect-the Yellownecked Apple-tree Caterpillar. When at rest or alarmed the larvæ assume the peculiar position represented at $a$. These caterpillars are preyed upon by certain birds, notably the Blue Jay and Red-headed Woodpecker, and by various species of insect parasites.

Remedies._These defoliators may be destroyed by spraying their food plants with Paris green or London purple, or the larvæ may be crushed when gathered into heaps on the trunk at moulting time.

\section{The Woolly Maple Bark-Iouse.}

\section{Pulvinaria innumerabilis.}

The presence of this insect is manifested in the spring and early summer by the occurrence upon the twigs of maple trees, especially on the under side, 
of a brown, circular, leathery scale, about one-quarter of an inch in diameter, beneath which is a peculiar, fluffy, cottony mass (Fig. 72, $\alpha$ ). In the spring there may be found in each of these masses, great numbers (from 700 to 1,000) of small, white, spherical eggs. Early in summer these eggs hatch into young lice, which scatter over the trees, wandering about on the twigs and leaves for a few days, and, finally, fixing themselves upon the lower leaf surface, insert their tiny beaks and suck out the sap. They remain in
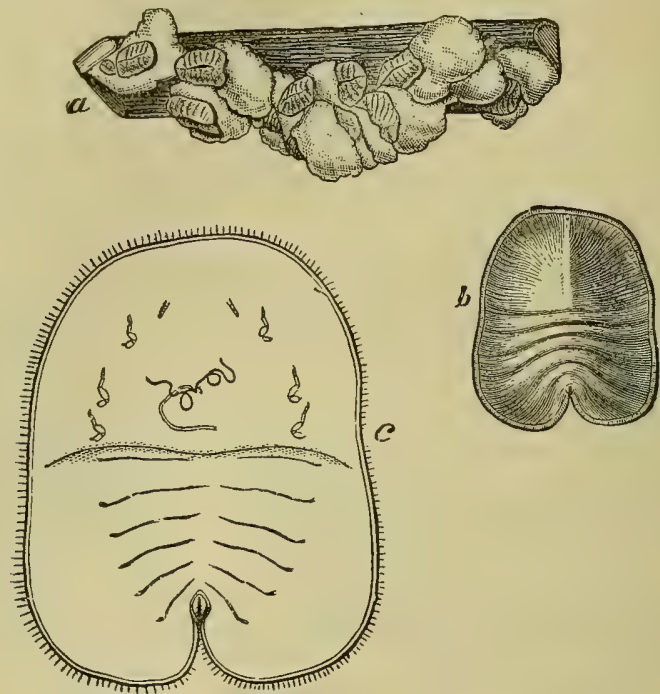

Fig. 72. Maple Bark-louse: $a$, cottony scales on twigs; $b$, back view of scale, magnified; $c$, ventral view of scale, more magnified.

this position several weeks, when a few of them become fully developed winged males. These mate with the remainder, which are females, and soon die. 
But the females remain upon the leaves until nearly time for them to fall in autumn, when they desert them and migrate to the twigs, attaching themselves by inserting their beaks into the bark. Here they remain until the following season, the eggs gradually developing and being deposited during spring.

These insects sometimes do great damage to maple trees. They excrete or secrete a peculiar liquid which falls upon the leaves, and the ground beneath the trees, which is sometimes called 'honey dew.' There are a large number of parasitic and predaceous insects that prey upon this species, and suppress its periodical uprisings.

Remedies.-In cities where a stream of water from hose connected with water-works is available, the trees can be largely cleared of the pests by repeated drenchings. In the spring before the eggs hatch, and also while the young lice are crawling over the tree, soon after hatching, is the best time for this work. The young lice may also be easily destroyed by spraying with kerosene emulsion. This should be done in June, soon after they hatch.

\section{The Box-elder Bug.}

Leptocoris trivittatus.

In the region west of the Missouri river this insect is extremely abundant, causing serious injury to the Box-elder, and occasionally, also, to ash, maple, and other trees. The adult (Fig. 73) is a dull black bug about half an inch long, having blood red ocelli, and 
various red markings on the wings and body. "During the winter," according to Professor E. A. Popenoe, who has studied the insect carefully, "the adults are hidden in sheltered nooks and corners everywhere, but are especially abundant in crevices of stone walls and angles of stone buildings, on the south sides of which they appear, singly and in clusters, every warm day during the seuson. As soon as the increasing warmth of spring allows, they leave these shelters and seek the trees attacked by them. The

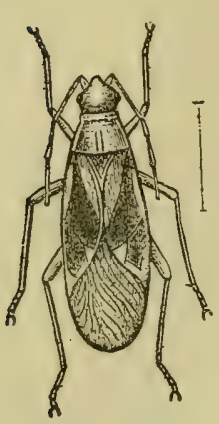

Fig. 73. Box-elder Bug. Magnified eggs are laid in creases of the bark, on the trunk and twigs. After midsummer their gregarious tendency is manifested in the flocking of bugs of all sizes and in great numbers, in lines up and down the trunks and branches, the company including larvæ of all sizes, pupæ, and fully matured individuals. This habit persists more or less completely until October and November, or until the trees are bare. During the warm days of Indian summer the bugs fly everywhere, flocking to the warm sides of the buildings, and entering houses, where, though otherwise harmless, they become troublesome through their abundance, and propensity to fall clumsily into pails of water, crocks of milk, and other articles of food left uncovered."

This insect, like all true bugs, is active during its entire existence, and gets its food by sucking sap 
through a sharp-pointed beak which is inserted into the bark of the succulent twigs, and also into the leaves. It has comparatively few natural enemies.

Remedies.-These bugs may easily be destroyed when gathered in clusters on trees or walls by pouring boiling water, gasoline or kerosene upon them.

\section{INJURING THE BRANCHES.}

\section{The Spotted Willow-twig Aphis.}

\section{Melanoxanthus salicis.}

The various species of willow are particularly subject to the attacks of aphides or plant lice. No less

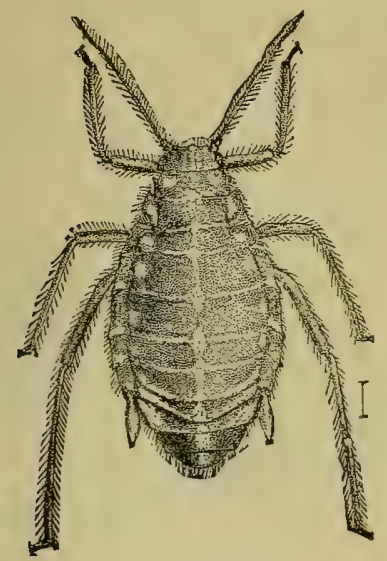

Fig. 74. Spotted Aphis: oviparous female. Magnified. than nine of these insects have been described as preying upon them. No part of the tree, except, possibly, the root, is exempt from attack, and the bark and twigs receive the exclusive attention of at least five species. Some of these often become seriously injurious, and more frequently, perhaps, their presence is extremely annoying where they occur upon shade or ornamental trees in private grounds or public parks.

The aphides most commonly found upon willow twigs belong to the genus Melanoxanthus. Three 
American species of the genus are known." The Willow-grove Aphis (M. saiicti) is probably the commonest in the eastern and middle states. : It is very similar in appearance and habits to the nearly related Spotted Willow-twig Aphis, represented at Figs. 74 to 76 . This insect lives over in the egg state on the bark of willow twigs. Early in spring the eggs hatch into young plant-lice which insert their tiny beaks into the tender bark and suck out the sap. They grow rapidly, and each one soon becomes the

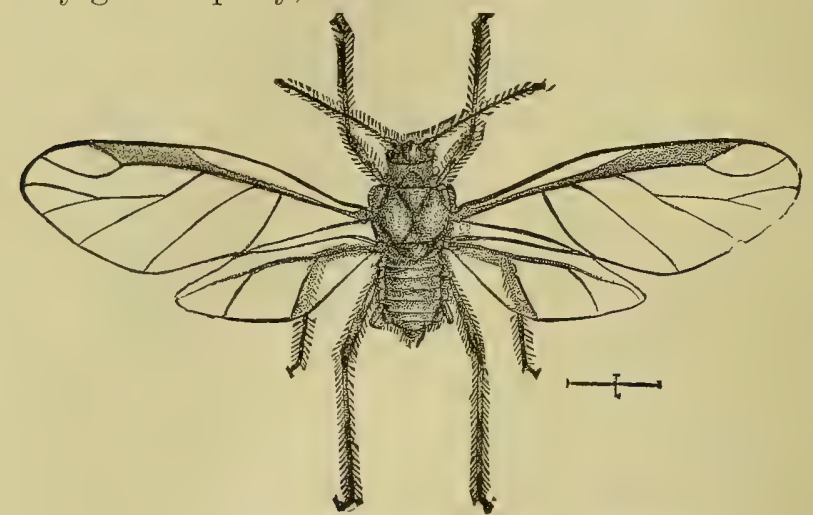

Fig. 75. Spotted Aphis: winged male. Magnified.

mother of several young aphides. The generation from the egg are all wingless, but those of the second generation probably develop into both winged and wingless forms, which are also viviparous. Successive broods continue to appear throughout the entire summer, all being viviparous, and some having wings while others have none. By midsummer they have often increased so enormously as to cover all the twigs of infested trees, making them appear 
filthy and unsightly, as well as impairing their vitality by extracting the sap. A single one of the aphides hatched from the egg in spring may become the ancestor of many millions before autumn. But in October a true sexed generation develops, the males being winged and the females wingless. By the union of these two the true eggs are obtained.

The wingless forms, whether viviparous or oviparous, do not differ materially in appearance. The oviparous, or egg-laying, form is represented at Fig. 74: it is about one-fifth of an inch long, bluishblack in color, with a glaucous bloom. It has a distinct white longitudinal line along the middle of

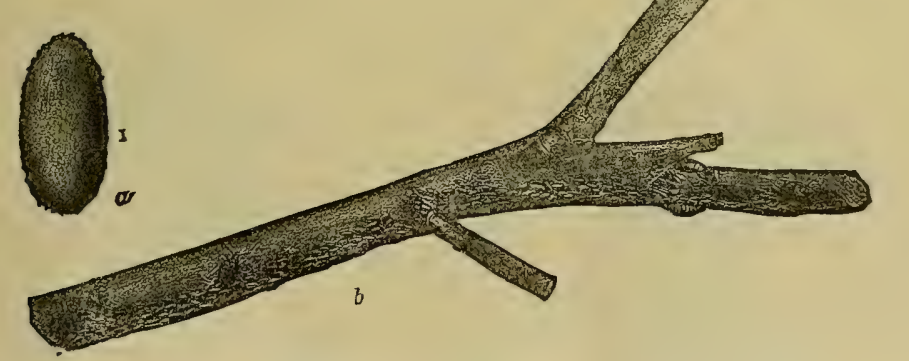

Fig. 76. Spotted Aphis: $a$, egg, magnified; $b$, oviparous females depositing eggs.

the back, and a row of white spots along each side. The cornicles, or honey-tubes, are bright orange yellow. The male (Fig. 75) is one-fifth of an inch long, with a wing expanse of one-third of an inch. The 
body is bluish-black, with the wings transparent and their veins yellowish-brown.

The oviparous females congregate for the purpose of depositing their eggs in one or a few places on the tree, where they cover the bark with them (Fig. 76). The egg $(a)$ is about one-twentieth of an inch long and oval in form; when first laid it is covered with a liquid which on exposure to the air dries into a thin, grayish, irregular covering, suggestive of felt.

Remedies.-Spray with kerosene emulsion; cut off and burn the limbs on which the eggs are laid.

\section{The Toothed Willow Aphis.}

\section{Lachnus dentatus.}

This is the largest of the aphides affecting the willow, being in fact one of the largest known species
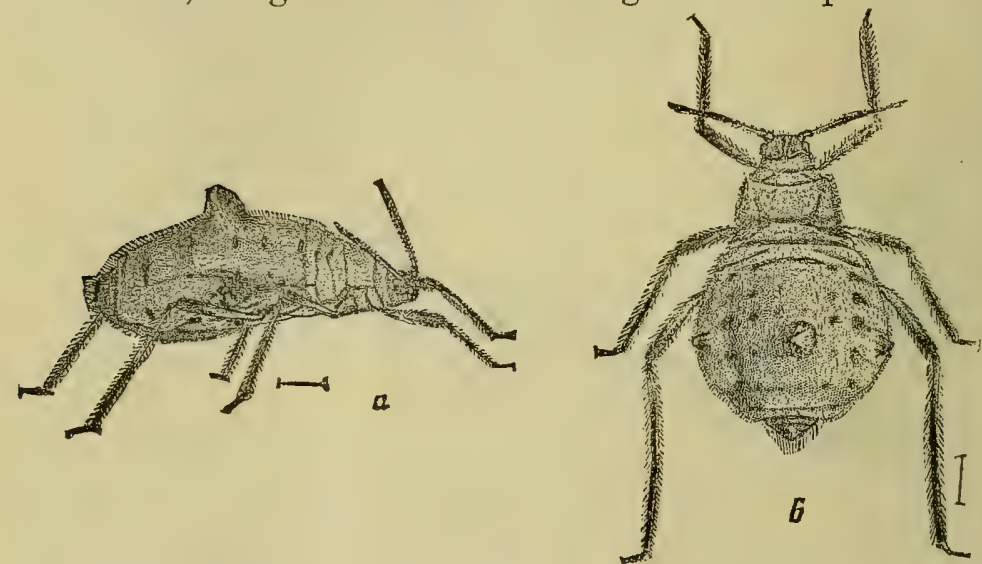

Fig. 77. Toothed Willow A phis, viviparous female: $a$, side view; $b$, back riew. Magnified of this family. The wingless forms are one-fourth of an inch long. Its life-history is much like that of 
the Spotted Willow Aphis described above, except that it prefers the trunk and larger limbs to the twigs. The sexed individuals appear in autumn, and the eggs are probably laid upon the bark. The species is characterized by a large tooth-like tubercle on the middle of the back of the abdomen (Fig. 77).

Remedies.-A strong kerosene emulsion sprayed upon the bark will destroy these creatures.

\section{The White Pine Aphis.}

Lachnus strobi.

This insect is a midely distributed species, and on account of its egg-laying habits it is liable to be introduced everywhere with pine trees from nurseries. It frequently becomes so numerous as to do serious - injury to White Pines in ornamental grounds.

Like most plant-lice, this species reproduces viviparously, or by giving birth to living young, during the summer, but on the approach of cold weather the sexual individuals are produced. During October these are usually the only forms present, the oviparous $\mathrm{fe}$ males being congregated in great numbers upon the bark of the smaller branches, with their heads nearly always directed towards the trunk of the tree. When disturbed they move about rapidly, Fig. 7s. White Pine Aphis:

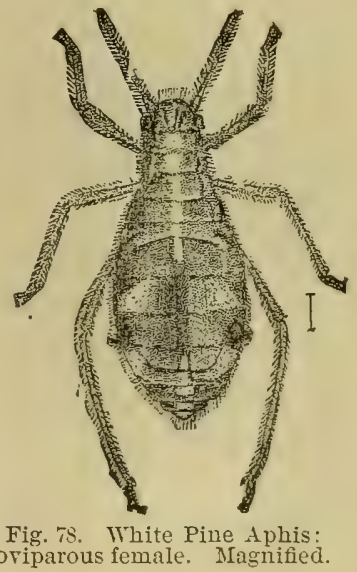


usually attempting to conceal themselves on the other side of the branch. At such times they also have a curious habit of waving their long hind-legs in the air, probably for the purpose of frightening away predaceous or parasitic enemies.

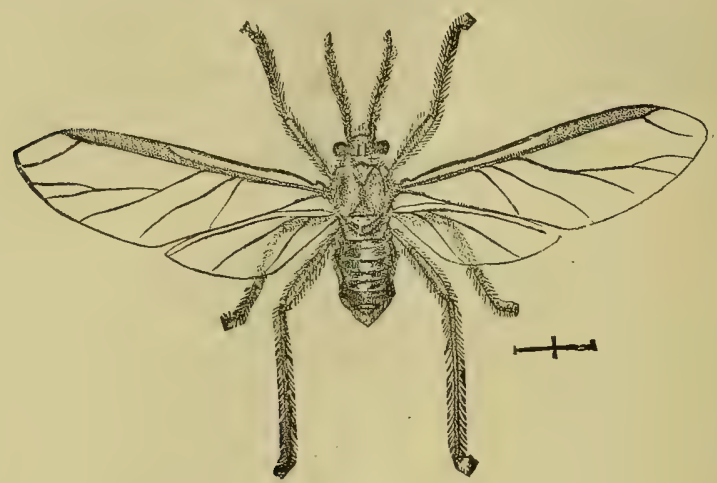

Fig. 79. White Pine Aphis: winged male. Magnified.

The oviparous female is represented, much mag-nified, at Fig. 78. It is nearly one-fifth of an inch long, shining black, more or less tinged with brown, and ornamented with spots and stripes of white. The wingless viviparous females do not differ essentially from this form. The winged male (Fig. 79) is about one eighth of an inch long, with a wing expanse of a quarter of an inch. It is blackish, with a slight glaucous bloom, and a whitish longitudinal line along the middle of the back. The wings are subhyaline, with the veins dark-brown, and the stigma almost black. The antennæ and legs are quite hairy. 
The eggs are deposited during October and November, on the leaflets, in rows, as represented at Fig. 80. Each egg is not quite one-tenth of an inch
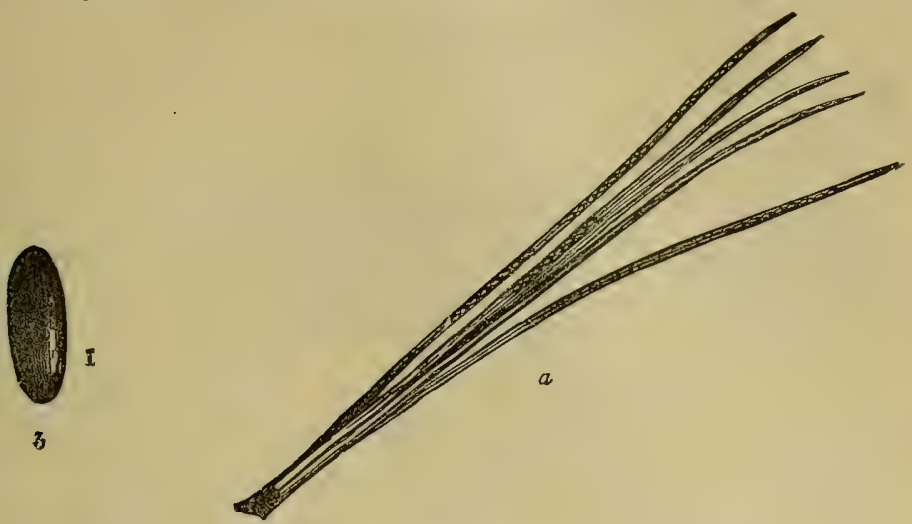

Fig. 80. White Pine Aphis: $a$, eggs on pine leaf, natural size; $b$, single egg, magnified.

long, elongate-oval, brownish when first laid, but becoming black in a short time.

Remedies.-Kerosene emulsion is the most effective insecticide with which to combat this insect. It should be sprayed upon the infested trees early in the season, before the aphides become too abundant. The best time to apply it would be just after the young lice hatch from the eggs; they are then rery tender and easily killed. 


\section{INSECTS AFFECTING THE ROSE.}

\section{INJURING THE LEAVES.}

\section{The Rose Slug.}

Selandria rosæ.

This insect is familiar to most lovers of the queen of flowers, and is justly dreaded on account of its serious injuries. But no one should allow it to prevent the planting and enjoyment of roses, for it is easy to keep the pest in check.

The Rose Slug is the young or larva of a fourwinged saw-fly, related to the parent of the Pear-tree Slug and the Imported Currant Worm. It bears a general resemblance to the fly shown at Fig. 81, which represents the adult of the Pear-tree Slug. The larvæ shown in the figure will also serve to illustrate the appearance and mode of work of the Rose Slug. According to Dr. Harris, the parent saw-flies, in the latitude of Massachusetts, "come out the ground at various times between the 20th of May and the middle of June, during which season they pair and lay their eggs. The females when about to lay their eggs turn a little to one side, unsheath their saws, and thrust them obliquely into the skin of the leaf, depositing in each incision thus made, a single egg. The young begin to hatch in ten days or a fortnight after the eggs are laid. The period of their existence in the caterpillar state probably does not exceed three weeks. They have a 
small, round, yellowish head, with a black dot on each side of it, and are provided with twenty-two short legs. The body is green above, paler at the sides, and is soft and almost transparent, like jelly. The skin of the back is transversely wrinkled, and covered with minute elevated points; and there are

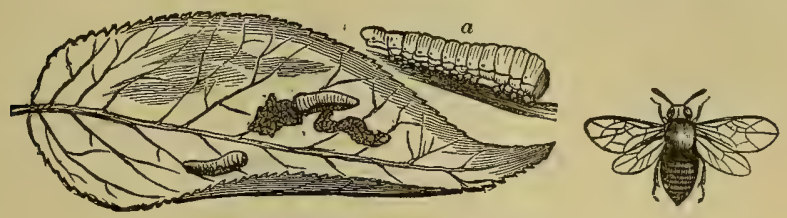

Fig. 81. Pear-tree Slug: fly and larvæ.

two small, triple-pointed warts on the edge of the first ring, immediately behind the head. These gelatinous and sluggish creatures eat the upper surface of the leaf in large, irregular patches, leaving the veins and skin beneath untouched; and they are sometimes so thick that not a leaf on the bushes is spared by them, and the whole foliage looks as if it had been scorched by fire and drops off soon afterwards. They cast their skins several times, leaving them extended and fastened to the leaves; and afterthe last moulting they lose their semi-transparent and greenish. color, and acquire an opaque, yellowish hue. They then leave the bushes, and burrow an inch or more in the earth, where each one makes for. itself a small, oval cell of grains of earth, cemented with a little gummy silk." They remain ịn these pupa cells until the following season, when they: emerge as flies. 
Remedies.-In cities where a stream of water from a sprinkling hose is always available, the simplest plan of keeping these pests away is to spray the bushes forcibly every day or two, to frighten away the flies and wash off the larvæ. If this process is gone through with sufficient force and thoroughness, it is the neatest and best remedy. The slugs also may be easily killed by spraying or dusting the infested bushes with helleboré or insect powder.

\section{The Rose Leaf-hopper.}

Typhlocyba rose.

Owners of rose bushes are frequently annoyed by finding the lower sides of the leaves covered with a small white insect that sucks out the cell contents and gives the upper surfaces a peculiar white-spotted appearance (Fig. 82). This is the Rose Leaf-hopper, a species that has been known to injure these lovely ornamental plants for nearly a century. The adult, shown considerably magnified at Fig.

Fig. 82. Rose leaf injured by leaf-hoppers.

$83, a$, is a little more than onetenth of an inch long, with a yellowish-white body, and white, semi-transparent wing-covers. In common with other leaf-hoppers this insect has long 
hind legs, by means of which it is enabled to make tremendously long leaps when disturbed. The fully grown nymph $(b)$ is also whitish, and its back is well protected by numerous long spinous hairs. There are said to be several broods each season

\section{Remedies.-These} little pests are much easier to destroy before they are fully

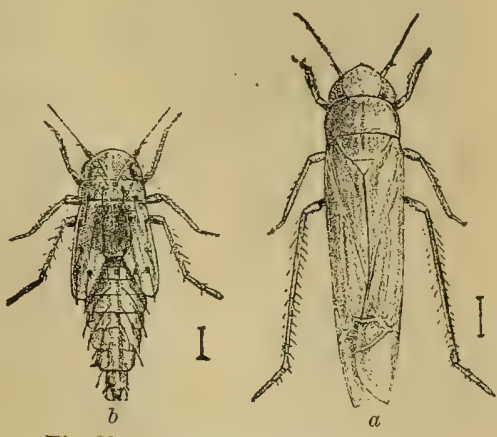

Fig. 83. Rose Leaf-hopper: $a$, adult ; $b$, pupa. Magnified. developed than afterwards. Spraying or dusting the infested plants with pyrethrum, or insect powder, is a simple and efficient remedy. Tobacco, in the form either of a powder or a decoction, is also good; and kerosene emulsion will destroy the pests.

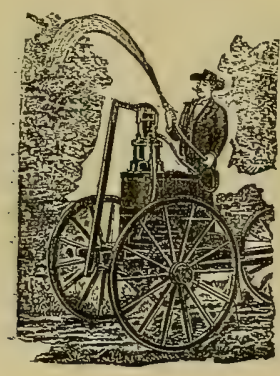




\section{INSECTS AFFECTING FLOWERS IN THE WIN- DOW-GARDEN AND GREEN-HOUSE.}

\section{INJURING THE LEAVES.}

\section{Plant-lice or Aphides.}

There are many different species of aphides, plantlice, or "green flies," affecting the various flowering plants. But all are quite similar in life-history and habits, and the same remedies apply to each. They all multiply with marvellous rapidity on account of

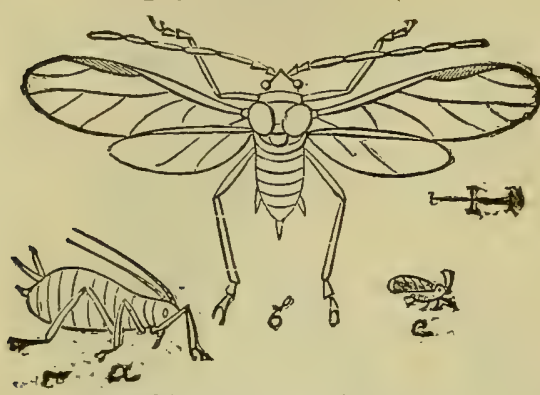
Fig. Aphis: a, wingless form, magnified; pointed beaks into $b$, winged form, magnified; $c$, same, natural size.

their habit of giving birth to living young without the presence of male. aphides. $\mathrm{Th}$ e $\mathrm{y}$ mature 'rapidly, and obtain food by inserting their the stem or leaf, and sucking out the sap. There are generally two forms of them, one being winged (Fig. 83, b, c) and the other wingless $(a)$. . These insects are the commonest pests of flowering plants.

Remedies.-Tobacco is the great specific for these. insects. It may be used in various forms, but generally the most satisfactory form is that of the refuse- 
powder of the cigar factories. This should be used' freely as a mulch for low-growing plants, such as the daisy ; and if blown upon infested plants, having first sprayed them with water, by means of a powderbellows or Leggett's powder-gun, it will clear them readily. In green-houses tobacco stems are commonly used to smoke the plants. A few live coals. are put upon a shovel, or into a metal bucket, and refuse tobacco stems are laid upon them. The house. is then tightly closed and the smoke allowed to remain several hours. The greatest objection to this. method is that tender plants are liable to be seriously injured by an over-dose of the smoke. The tobacco. may also be used in the form of a decoction, made by pouring hot water on the stems, allowing it to cool, and then drawing off the liquid. This may be sprayed upon the plants, or, where not too large, the plants may be dipped into the liquid. For windowgarrlens this is perhaps as satisfactory a method as. can be suggested.

\section{The Red Spider.}

Tetranychus telarius.

Green-house plants are often seriously injured by multitudes of very minute reddish mites that congregate on the lower leaf surface, spinning a very fine protective web, and sucking out the juices of the plants through their infinitesimal beaks. These little creatures are commonly called Red Spiders. They are distantly related to ordinary spiders, and 
like them have, when fully developed, four pairs of legs. They multiply beneath their silken webs, where one may find colonies of individuals (so small as to be scarcely visible to the naked eye) in all stages of existence. The young have but three pairs of legs. The egg is very small and spherical, being nearly colorless. The infested leaves assume a yellowish hue, and many of them finally drop off.

Remedies.-The Red Spider flourishes best in a dry atmosphere. It is seldom troublesome in greenhouses where the air is kept saturated with moisture and the plants are sprayed with water every day. In window-gardens the plants should be sprayed with soap suds, tobacco decoction or kerosene emulsion, or dusted with fine tobacco powder, as soon as they show signs of the presence of this pest.

\section{Mealy-bugs and Scale-lice.}

Mealy-bugs are among the commonest and most vexatious green-house pests. They occur upon a great variety of plants, and reproduce freely throughout the year. There are two or three species commonly found in this country, the most destructive, perhaps, being the species called by entomologists Dactylopius adonidum, which is distinguished by two long, white, cottony threads extending backward from the last segment of the abdomen. Another common species is called Dactylopius destructor.

Mealy Bugs derive their oommon name from a peculiar yellowish-white substance, resembling flour 
or meal, which they throw out from numerous minute pores along the sides of their bodies. This serves both as a protection from enemies, and also as a place of concealment for the eggs of the insects.

Woody green-house plants, such as the Oleander, Orange, Abutilon, etc., are also often infested with scale insects that occur upon the stems, sucking out the sap and so absorbing the vitality of the plants. These belong to the same family of insects as the mealy-bug's, to which they bear a general resemblance in life-history and habits.

Remedies.-When a plant is once badly infested with either of these pests it can be cleared only by thorough and careful work. As many should be rubbed or brushed off by hand as possible, and then the plant may be sprayed with kerosene emulsion, which, however, should be used with caution on the more tender varieties of greenhouse plants. It is not necessary to treat the whole plant, but only the parts infested by the insect. In case only a few mealy-bugs are present they may be killed by dipping a small brush in alcohol and then saturating the colonies of the insect with it. Or the affected part of the plant may be washed with a forcible stream of water till all signs of the insects or their eggs are removed. Professor Comstock reports an experiment in which equal parts of smoking tobacco and flowers of sulphur were ground together in a mortar until thoroughly mixed, and the compound thus fcrmed was dusted over wet infested plants, and the mealy bugs destroyed. 
Out of doors, and to a certain extent in the greenhouse also, these mealy bugs and scale insects have various natural enemies to contend with: Chief among these are the little lady bugs (a common species of which is represented, much magnified, in the cut below), and certain parasitic flies.

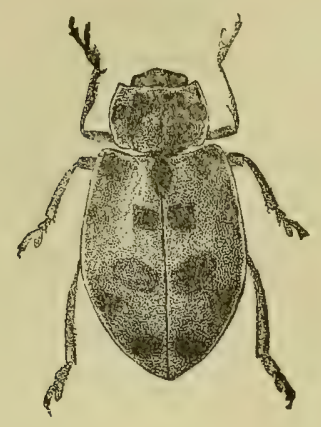




\section{PART IV.}

INSECTS AFFECTING VEGETABLES. 


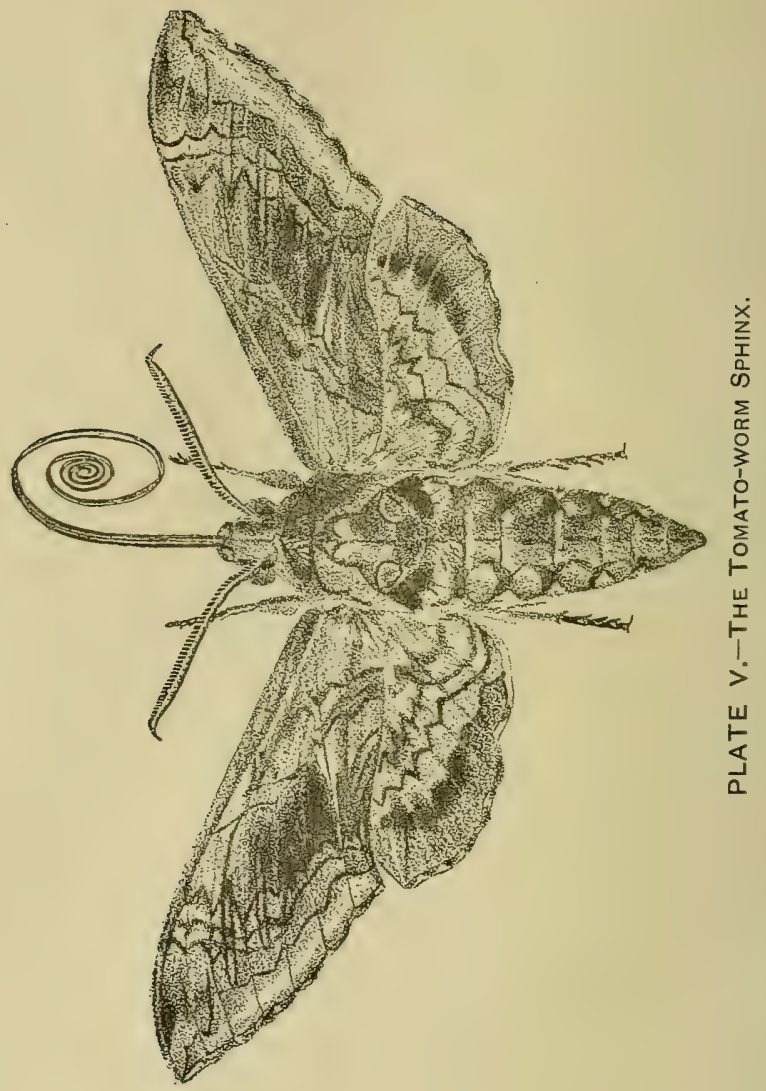




\section{INSECTS AFFECTING THE TOMATO.}

\section{INJURING THE LEAVES.}

\section{The Tomato Worm.}

\section{Phlegethontius celeus.}

This insect in its larval state is familiar to every one who has owned a garden. The moths, which belong to the handsome Sphinx family, appear early in summer, and fly about just at dusk, sipping the nectar from various flowers through their long tongues or sucking tubes. Their general appearance is well illustrated at Plate V. The ground color of the body and wings is gray, and there are various dots and stripes of different shades. On each side of the abdomen are five orange-colored spots. The female moths lay the eggs in the evening on tomato plants, where they soon hatch into green worms that feed voraciously on the foliage. These caterpillars grow rapidly, and in a few weeks become three inches long and nearly as thick as a man's finger. They are light green, with several oblique, whitish stripes along each side of the body: sometimes brown specimens are found. Early in September, in the Northern States, these caterpillars complete their larval growth, and burrow into the ground some distance, where they form oval cells in the soil, shed their larval skins, and change to pupæ. The pupa 
or chrysalis (Fig. 85) is of chestnut-brown color, with a long and slender tongue case bent over like the handle of a jug. They remain in this state until the following summer, when they come forth as

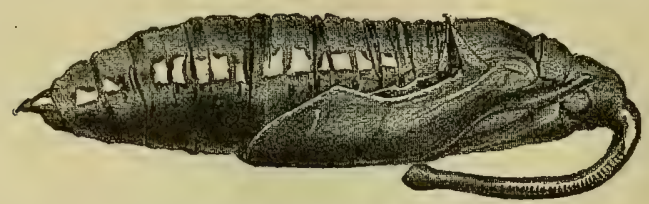

Fig. 85. Pupa of Tomato Worm.

moths. Besides the leaves, the caterpillars often feed upon the green fruit of the tomato, as well as upon the foliage of the potato and tobacco.

There is another species similar to this one, and often confounded with it. The life-history and habits of the two are much alike. The moth of the other one is called the Carolina Sphinx (Phlegethontius carolina). In the Southern States, and even as. far north as central Ohio, there are two broods each season.

The Tomato Worm is subject to the attacks of a small, four-winged, black fly that deposits eggs beneath its skin along the back. The eggs hatch into little maggots that absorb the body juices of the worm, developing at its expense, and finally coming out upon its back; where they spin white, silken cocoons (Fig. 86), within which they change to pupæ. Shortly afterward they again change to flies that gnaw out of the cocoons and fly away to continue the work of destruction. The caterpillar lingers awhile in a half dead condition, and finally dies. 
Remedies.-Hand-picking the worms is the most effective remedy for garden patches. Their depredations are so conspicunus that.it is generally easy to find them. The moths may be destroyed (and consequently the deposition of eggs prevented) by smearing flat boards in various parts of the field with

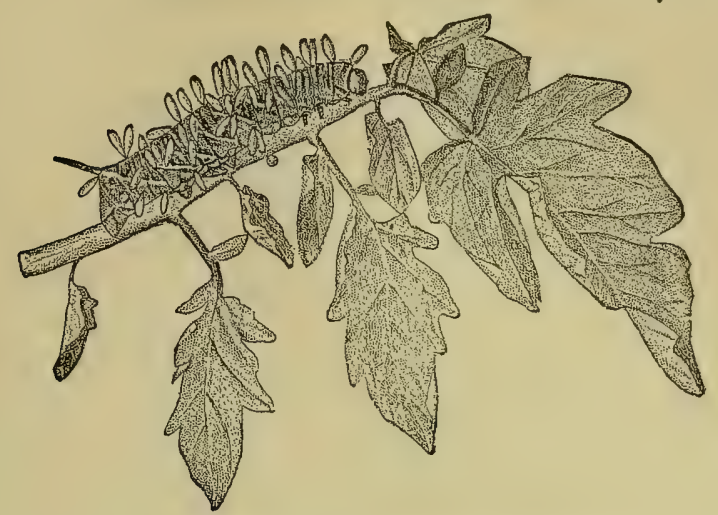

Fig, 86. Tomato Worm with cocoons of parasite.

molasses mixed with stale beer, to which a little fly poison has been added. The boards should be a foot or two from the ground. Another method which is especially recommended for killing the moths in tobacco fields, is to plant at occasional intervals in the field seed of Jamestown Weed (Datura stramonium) about the time the tobacco is put out. These will come in blossom when the moths appear. If a little fly poison, mixed with sweetened water and whisky, be poured in the long blossoms each evening, the moths that sip the liquid will be killed. 


\section{INSECTS AFFECTING THE POTATO.}

\section{INJURING THE STEM.}

\section{The Potato Stalk-weevil.}

Trichobaris trinotata.

Potato stems are sometimes infested by a whitish or yellowish-white, footless grub, about a quarter of an inch long, which burrows in the heart of the stalk, especially near the ground, and causes the plant to wilt and die. This is the larva of a small, grayish snout-beetle, called the Potato Stalk-weevil, the females of which deposit their eggs, singly, in a slit made for the purpose in the stem, slightly above the soil surface. In a few days the egg hatches into a little grub that burrows down the center of the stem toward the root. A few weeks later, still within the stalk and slightly below the surface of the ground, the larva pupates, and late in summer or early in autumn it emerges as an adult weevil. This weevil passes the winter under whatever protective covering it may find, and the following season starts another generation by depositing its eggs in the potato stalks.

The injuries of this insect are sometimes quite severe. In Iowa, during the season of 1890 , Professor C. P. Gillette estimated that 75 per cent. of the potato plants were infested by it. It is a widely distributed species. 
Remedies.-According to Professor Gillette, "the only remedy at present known is to pull the vines as soon as they are found wilting and burn them. If the tops are left until it is time to dig the potatoes many of the beetles will have matured and escaped, and these will live over winter and lay eggs for another brood." But even late pulling and burning will destroy many of the pests, and in regions where this insect is known to be at work, the vines should be burned when pulled up in harvesting the crop.

\section{INJURING THE LEAVES.}

\section{The Colorado Potato-beetle.}

Doryphora decemlineata.

This insect originally lived upon a wild variety of Solanum (the genus to which the cultivated potato belongs) in the West, near the base of the Rocky Mountains. It was not known as an injurious species until about 1860 , when it attacked potatoes in the gardens of settlers in Kansas and neighboring states, and thereafter gradually spread eastward until it finally reached the Atlantic coast, and was carried across to Europe, becoming extremely destructive wherever it appeared.

The adult Colorado Potato-beetle (Fig. $87, d$ ) is too familiar to American gardeners to need description here. Its orange-colored eggs $(a)$ are deposited in masses, varying in number from a dozen to fifty 
or more, on the under surface of the potato leaf, and occasionally also upon the leaves of grass, smartweed, or other plants in the potato field. They hatch about a week later into peculiar little grubs: (b) that feed upon the foliage a few weeks. They

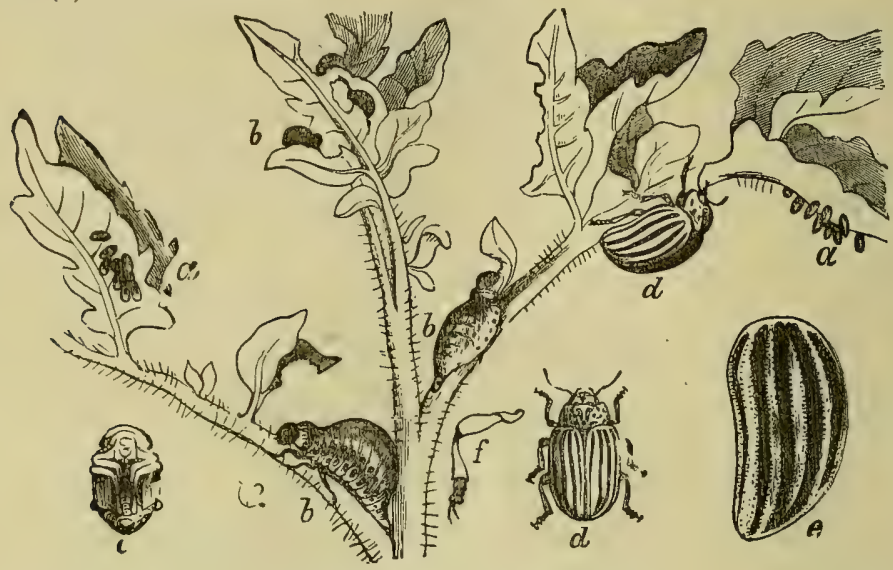

Fig. 87. Coloradó Potato-beetle; $a$, $a$, eggs; $b, b$, larvæ; $c$, pupa; $d, d$, beetles; $e$, wing of beetle, magnified.

then descend to the ground, where just beneath the soil surface, or under rubbish above it, they change to pupæ $(c)$. About ten days later they emerge as perfect beetles. There are from two to four annual broods, the number varying with the latitude; and the insect hibernates in the beetle state.

Like most other insects, the Colorado Potato-beetle fluctuates greatly in numbers and destructiveness. In any given locality it will be very destructive for a period of years, and then there may be several seasons when its injuries will hardly be noticed. 
This oscillation is probably due to the various natural enemies of the insect.

Remedies. - The standard remedy for this pest is that of spraying or dusting with some form of arsenic, such as London purple, Paris green, Slug Shot, Peroxide of Silicates, etc. All of these take effect both upon the larvæ and beetles. London purple or Paris green may be dusted or sprayed on with a perforated can or a powder-gun, or spraying machine. If used as a powder, the poison may well be diluted with several times its bulk of plaster, finely sifted ashes, or flour. In spraying use six or seven ounces of London purple or Paris green to fifty gallons of water. For this purpose London purple seems preferable on account of its cheapness and finely powdered condition. The application should be made as soon as the beetles appear, in order to kill off the first brood, and it must be repeated as often during the season as is necessary to keep the pests in check. By many growers hand-picking of the beetles and eggs, especially early in the season, is resorted to instead of the use of poisons. This method is effective if thoroughly carried out.

\section{The Striped Blister-beetle.}

\section{Epicauta vittata.}

This insect is sometimes called the Old-fashioned Potato-beetle, because it was known as "The Potatobeetle" before the introduction of the more modern, as well as more destructive, Colorado species. It is 
a foe to the farmer only in its adult condition, for as a larva it feeds upon the eggs of various grasshoppers, forming one of the most efficient natural checks upon the increase of these pests. The adult blisterbeetle (Fig. 88) is a slender-bodied; rather longlegged insect, measuring from one-half to threefourths of an inch in length, with alternate stripes

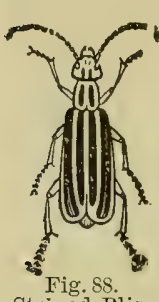

Striped Blis-

ter-beetle. of black and yellowish-brown upon the back. It feeds voraciously on the leaves of potatoes and various other vegetables. These beetles are generally gregarious, feeding in good-sized flocks, and when disturbed take to flight readily. The females deposit their small eggs in masses of a hundred or more, in the soil just below the surface. In about ten days the eggs hatch into curious little larvæ that burrow through the earth in search of the eggs of grasshoppers. A large proportion of them probably perish because they can find none, but those that are successful feed upon the eggs and go through a curious series of changes, which have been admirably described by Dr. Riley, finally going into the pupa state and emerging later on as beetles. In the South there are apparently two broods each season. On account of the dependence of the larvæ upon grasshopper eggs, the beetles are much more likely to be destructively numerous during seasons following those in which grasshoppers have been abundant.

There are several other species of blister-beetles with habits similar to this one, that are frequently 
found upon potatoes. The commonest is probably the Black Blister-beetle (Epicauta pennsylvanica).

Remedies.-It is sometimes stated that these insects are not destroyed by eating Paris green, but this is doubtless a mistake. The application of this substance, however, seems often to be of no avail, probably either because it does not act immediately upon the beetles, or else because they continue to invade the field from the outside. A few years ago a favorite method of destroying them was to drive the flocks of beetles upon loose hay or straw spread upon the ground near where they are at work, and then burn the hay, lighting it at several different places, so that it will burn rapidly. Hand picking can often be resorted to advantageously It is doubtful policy, however, to destroy these insects except. when they threaten to do serious damage, because of the grasshopper-egg feeding habits of the larvæ.

\section{The Imbricated Snout-beetle.}

Epicæerus imbricatus.

This is a small beetle about half an inch long, silvery white in general color, with various darker markings upon its back, of the form represented at Fig. 89. It feeds upon a great variety of vegetation, from the twigs and fruit of apple, cherry and gooseberry to the leaves and stems of onion, radish, melon, beans, beets, corn and potato. It often does very 
serious injury in the vegetable garden, but notwith-

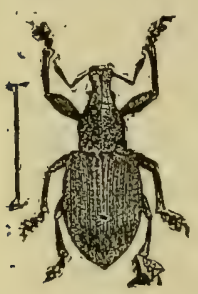
standing its commonness and destructiveness, its life-history as yet has not been traced. Professor Forbes has found the eggs deposited between pear leaves fastened together, and Dr. Riley has conjectured that the larvæ will be found to feed externally on the roots of one or Fig. 89. Imbrica- more of the food-plants of the beetle. ted Snout-bee- When alarmed the beetles feign death,
tle. Magnified. When resembling in this respect the Plum Curculio, and fall to the ground.

Remedies.-When these insects infest plants to which Paris green or London purple can safely be applied, the potato for example, they may easily be destroyed by such applications.

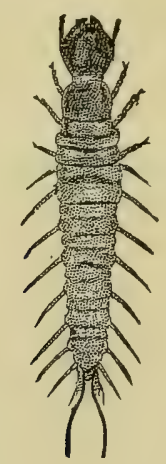




\section{INSECTS AFFECTING CELERY, PARSNIP AND CARROT.}

\section{INJURING THE LEAVES.}

\section{The Celery Caterpillar.}

\section{Papilio asterias.}

The life-history of this insect has been discussed at some length in the Introduction (pages 9-11) in connection with Plate I, where its different stages are illustrated. The larvæ are handsome and quite conspicuous, and feed upon the foliage of the various members of the parsley family, including the carrot, celery, parsnip, etc., sometimes doing considerable injury when left unmolested. The caterpillars often become the victims of certain parasitic insects, but it is said that neither birds nor domestic fowls will eat them, probably because of the disagreeable odor emitted from the peculiar yellow horns situated on the body, just behind the head. The adult butterfly is one of the most beautiful as well as one of the commonest of its family.

Remedies.-When young these caterpillars may be destroyed by dusting them with insect powder or buhach. Ordinarily, however, they are not so abundant but that a little hand-picking will readily hold them in check. 


\section{INSECTS AFFECTING THE SQUASH, MELON AND CUCUMBER.}

\section{INJURING THE ROOT.}

\section{The Squash-vine Borer.}

Aegeria cucurbita.

The roots and stems of cucurbitaceous plants are frequently infested with a whitish larva that feeds upon their inner substance, often doing so serious a damage as to cause the plant to wilt and die. The parent of this Squash-vine Borer is one of the Aegerian moths, several kinds of which are represented at Plate II (p. 28).

It is a handsome insect (Fig. 90), about half an inch long, with an orange-colored Fig. 90. Squash Vine-borer: larva and moth. body ornamented by several black spots upon the back, and having olive-brown front wings and transparent hind ones. Eggs are deposited by this moth upon the stems of the young plants near the roots, and the larvæ resulting burrow into the center and feed upon the succulent interior. They remain here several weeks, gradually increasing in size. Toward the end of summer they become full grown (Fig. 90), when they measure about an inch in length, and are whitish with brown heads. They now leave the 
stem or root and form cocoons in the earth by fastening particles of soil together with their gummy silk. They then change to pupæ, and remain thus until the following season, when they emerge as moths.

Remedies. - The remedy most generally recommended is that of cutting out the borers with a sharp knife as soon as their presence is suspected. It is well to cover over sections of the stems at different places to induce them to take root at various joints, so that if the main root is injured the plant can continue to grow from these additional roots. It is claimed by some that the injuries of the insect can be prevented by occasionally sprinkling, or dusting, the stems near the base, with Paris green.

\section{INJURING THE LEAVES.}

\section{The Cucumber Flea-beetle.}

Crepidodera cucumeris.

This is a small, blackish, punctate beetle (Fig. 91), about one-sixteenth of an inch long, with yellowish antennæ and legs, that appears early in spring, and as soon as the squash or cucumber plants are up, attacks them, eating off small, round patches of parenchyma from the upper surface of the leaves. Like all flea-beetles, they. are quite active, hopping readily when dis- Flea-beetle. turbed. The larvæ are said to mine the leaves. 
The insect does not confine itself to squashes and cucumbers, but feeds upon a great variety of other plants.

Remedies.-Powdered tobacco has been found to be the best preventive of the injuries of flea-beetles. When used against the Striped Cucumber-beetle, it will take effect upon the present pest as well.

\section{The Squash Bug.}

\section{Anasa tristis.}

The Squash Bug is too familiar to gardeners to need a detailed description here. It is a rusty-black, flattened bug, about half an inch long, with the under side ochre-yellow, and has a very repulsive 'buggy' odor. This insect winters over as an adult, beneath boards, logs, leaves, or other protective covering, and appears in the squash patch late in spring or early in summer. The females then deposit their brownish-yellow, spherical eggs on the under sides of the leaves in patches varying from three or four to a score or more. In a few days the young bugs, or nymphs, hatch, and insert their pointed beaks into the leaf and suck out the sap. At first they are more or less gregarious, the bugs from a single lot of eggs feeding together, but as they grow older they gradually disperse over the plants, casting their skins occasionally during their development. Like all true bugs, the transformations of this species are incomplete. The young bear a general resemblance to the adults, and the insect remains active in the stage corresponding to that of the pupa. Leaves 
attacked by the bugs become sickly and yellow, and if the pests are numerous the whole plant may finally be killed.

Remedies.-Hand-picking appears to be the most practicable remedy that has yet been tried. This should be done during the cooler hours of the day, when the bugs are sluggish. The young may also. be destroyed by spraying with kerosene emulsion. Professor Cook reports good success in placing pieces of boards among the plants, under which the bugs collect at night, and where they may easily be found and destroyed.

\section{The Striped Cucumber Beetle.}

Diabrotica vittata.

This is the small, yellow beetle (Fig. 92, b) with black stripes on its back that so commonly attacks squashes, cucumbers, melons, and other cucurbitace-
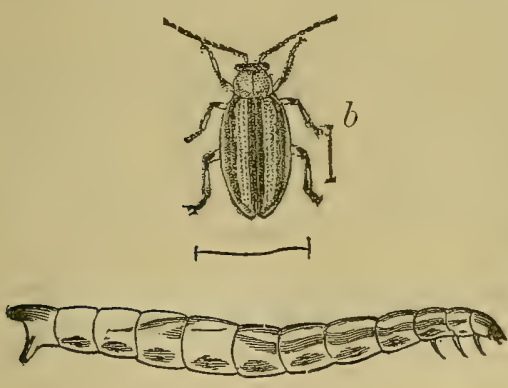

cl ous plants, soon after they come up in the spring. It feeds upon the leaves and stems, and in many parts of the country is so destructive that these plants can not be grown unless $a$
Fig. 92. Cucumber Betetle: $a$, larva; $b$, beetle.
Magnified.
are taken to guard against its injuries. The female beetles deposit eggs 
in the soil about the stems of the plants, and the larvæ resulting feed upon the roots. They reach maturity in a couple of months, having pupated within the soil. The larvæ (Fig. 92, $\alpha$ ) are whitish, cylindrical worms, not quite half an inch long, with three pairs of legs at the front of the body, and one pro-leg at the posterior extremity. The insect winters over in the beetle state, under leaves, logs, and rubbish of various kinds.

The beetles usually appear suddenly, often coming to the squash or melon field in great numbers within a few hours. Consequently a watch must be kept to prevent their doing damage before discovered.

Remedies.-There are probably few injurious insects for which more remedies and preventives have been suggested than this. But a large proportion of these methods are worthless. Good success has been obtained by applying liberal quantities of refuse tobacco powder to the hills. A shovel-full thrown upon the hills has been found largely to prevent the damage. The application should be repeated occasionally, when wind and rain have removed the powder from the plants. The tobacco acts not only as a repellent to the beetles, but also as a mulch and fertilizer to the plants. Similar, though less liberal, applications of phosphates, bone dust, and other commercial fertilizers, are also recommended by some authorities.

For the kitchen garden the most satisfactory method is that of protecting the plants by some form 
of gauze netting. A simple method of doing this is illustrated at Fig. 93. The ends of half a barrel hoop are placed in the earth at the sides of the hill, and a square strip of thin plant cloth or cheese cloth is then laid orer it, the cloth being:

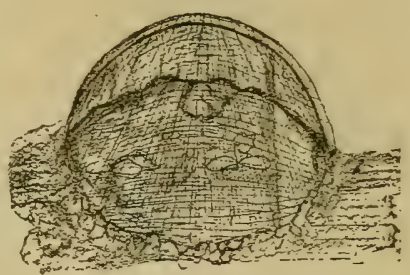

Fig. 93. Vine Protector. drawn taut, and the edges covered with loose earth. This excludes the beetles, and at the same time permits access of air, moisture, and sunshine. Squash plants are able to grow until they get four or fire leares, and cucumbers and melons eren more, before they are crippled by contact with the cloth. Wire may be substituted for the half barrel hoop. A single piece may be used, or two may be crossed like the center arch of a croquet ground, as represented at

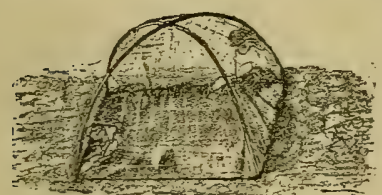

Fig. 94. Vine Protector.

Fig. 94. Good results are also obtained by simply placing the cloth over the plants without any support, and corering the edges as described. By loosening the cloth occasionally, the plant will lift it, and get several leaves before it need be removed. A modification of this method, which has been successfully used, consists of two end boards one-half inch thick, about fifteen inches long by six or eight inches wide. On the middle of each of these is nailed a piece of pointed lath at right angles to the long way of the board. The lower end of 
each lath projects below the edge of the board, and is stuck in the ground a few inches. Before the lath are put on, the end pieces are connected with each other by a piece of plant cloth about $16 \times 27$ inches, the ends being tacked to the top and sides of the boards. This protector has many advantages. It can be stored in very little space. When it is desired to cultivate the hills, it is only necessary to pull up one end, stir the earth, and put the end back in position.

Gauze covered wooden frames are sometimes recommended to prevent the injuries of this insect, but they are objectionable because they exclude a great deal of air and sunshine, causing the plants to grow tall and slender, rather than short and stocky.

\section{The Twelve-spotted Cucumber Beetle.}

Diabrotica 12-punctata.

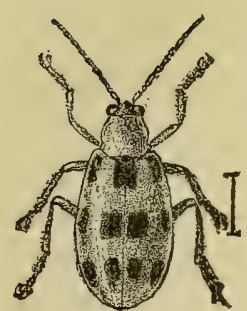

This insect is similar in appearance and habits to the one treated of last, the adult (Fig. 95) having twelve black spots upon a yellow background, instead of being striped. The larva of this species bores the roots of corn and other plants. The reFig. 95. Twelve-spot- medial measures recommended above ted Beetle. Magnified.

apply equally well to this insect. Its life-history will be found more fully discussed on a later page, where it is treated of as the Southern Corn Root-worm. 


\section{INSECTS AFFECTING RHUBARB.}

\section{INJURING THE STEM.}

\section{The Rhubarb Curculio.}

\section{Lixus concavus.}

Rhubarb stalks are frequently injured during spring and early summer by a grayish or brownish beetle that gnaws the surface (Fig. 96), and drills holes from which the gummy sap exudes. This is the Rhubarb Curculio, the three later stages of which are represented at Fig. 97. The larva is a wrinkled

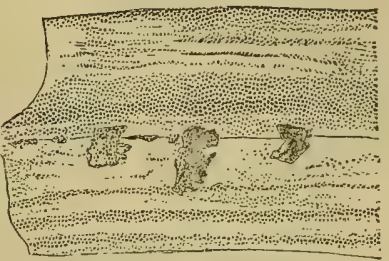

Fig. 96. Rhubarb stem injured by curculio.

legless grub of the form represented at $a$ : it is threefourths of an inch long, white, with a brown head. The pupa (b) is whitish and a little over half an inch in length. Thie adult beetle, whose general form is represented at $c$, is frequently covered with a yellowish powder that gives it a distinct yellowish appearance. When this powder is rubbed off the beetle is grayish-brown. In the figure the straight lines indicate the natural size of the specimens.

The insect hibernates as an adult, and comes forth in the spring to deposit its eggs in certain common species of dock, especially Curly Dock (Rumex crispus). The eggs are probably laid preferably in the 
young flower-stalk, but in the absence of these may

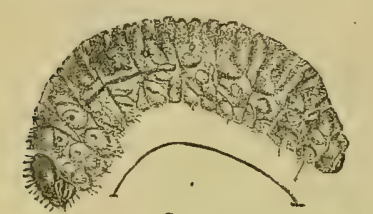

$a$ be deposited in the crown of the plant. The period of egg deposition is an extended one, very young larvæ occurring at the same time as pupæ, and there
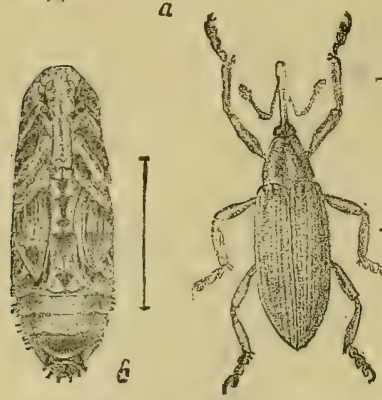

$c$
Fig 97. Rhubarb Curculio: $a$, larva; $b$, pupa; $c$, beetle. Slightly magnified.

being a difference of more than two months in the time of reaching maturity. The eggs probably hatch within a few days, and the larvæ feed upon the substance of the root or stem for several weeks. The eggs deposited early in the spring develop into beetles by the first of August, and the insects from the eggs deposited later continue to mature until October. Eggs are also often deposited in the rhubarb stalks, but they do not seem to be able to develop there. In some of the Western States the beetle is said to breed in wild sunflowers instead of the dock.

Remedies.CCollecting the beetles by hand, and pulling up and burming dock plants early in summer, are the most promising remedies yet suggested. 


\section{INSECTS AFFECTING THE BEAN AND PEA.}

\section{INJURING THE SEED.}

\section{The Bean Weevil.}

\section{Bruchus obsoletus.}

One often finds beans with numbers of excavations in them, like those shown at Fig. 98, b. Such beans are affected by the Bean Weevil-an insect that is widely distributed over the United States, and often does very serious damage.

The adult weevil is represented natural size in the upper middle portion of Fig. 98, and enlarged at $a$ of the same figure. It is a small, brownish insect that very much resembles the nearly related Pea Weevil, to which it is also similar in life-history and habits. The female beetle deposits eggs on the growing bean pods,

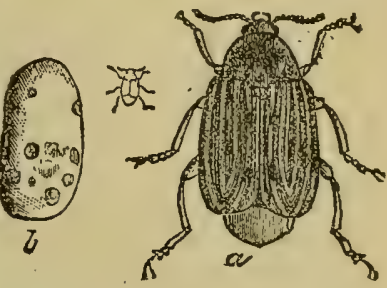

Fig. 9S. Bean Teevil: $a$, beetle, magnified; $b$, infested bean. and the larvæ, on hatching, gnaw through the pod to the young beans within. They enter these, feeding upon their substance, and remaining in them all summer, most of them pupating before autumn. A portion of them become adult beetles the same season, while others do not complete their transformations until the following spring. 
Remedies.-Beans infested by these pests should be inclosed in tight vessels, into which a little bisulphide of carbon, benzine, or gasoline has been placed. The fumes of these volatile substances will destroy the beetles. Of course care must be taken that no. particle of fire comes in the vicinity of the treatment. Late planting of the crop has been found a good way to prevent injury by an extensive Illinois farmer living in the latitude of St. Louis, Missouri, who, for a number of years, has planted his field beans from June 20th to July 10th, with good results. If the beans, as soon as ripe, are heated to $145^{\circ}$ Fahrenheit, the partially grown larvæ will be destroyed without injury to the germinating qualities of the seed. This will prevent much of the damage that would be done were the larvæ left to complete their growth.

\section{The Pea Weevil.}

\section{Bruchus pisi.}

As already stated, this insect is very similar to the Bean Weevil in life-history and habits. The adult. beetle deposits its yellow eggs on the outside of the young pods early in summer. On hatching, a few days later, the larvæ bore through the pods into the peas, which they enter and eat out the substance, leaving the radicle or germ untouched. On this account "buggy peas" will germinate, but as the young plants are deprived of the proper nourishment they make a less healthy growth than do those resulting from uninjured peas. When full grown the- 
larva eats a hole on one side of the pea, leaving only the thin, outer covering, before entering the pupa state. Some time afterwards the insect again changes to the perfect beetle, a portion of which emerge the same season, but most of them remain in the peas until the following spring.

Remedies.-The measures mentioned as remedies. for the Bean Weevil are equally applicable to this pest. That of heating the peas to $145^{\circ}$ Fahrenheit, as soon as gathered, seems especially advisable in the case of the Pea Weevil, for at the time of ripening a large proportion of the weevil larvæ are only partially grown.

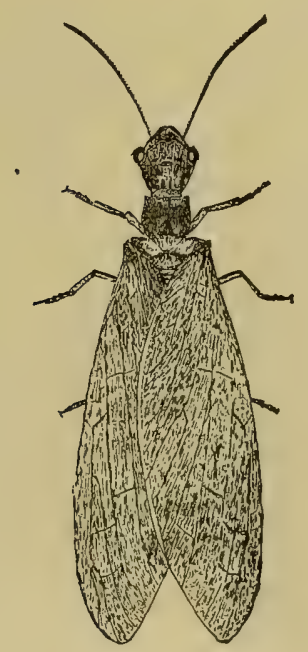




\section{INSECTS AFFECTING THE CABBAGE.}

\section{INJURING THE ROOTS.}

\section{The Cabbage Maggot.}

\section{Anthomyia brassice.}

The Cabbage Maggot is one of the most vexatious enemies of the gardener. The adult (Fig. 99, c) is a small, two-winged fly, somewhat like the common

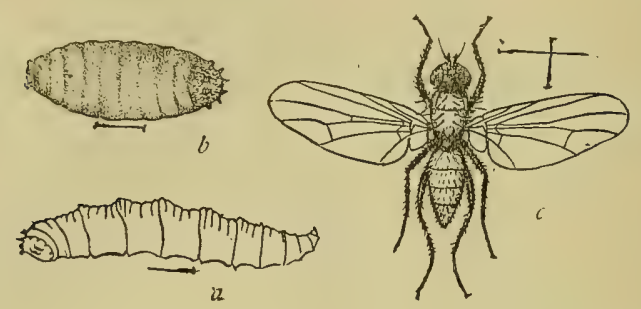

Fig. 99. Cabbage Maggot: $a$, larva; $b$, puparium; $c$, fly.

House-fly in general appearance, which appears in the cabbage field soon after the plants are set out, and deposits its eggs about the stems at the soil surface. The little, whitish maggots soon hatch, and work their way downward to the roots, which they attack, feeding upon the outer surface and thus making grooves, or boring into the interior and hollowing out cavities. They sometimes cause the roots to thicken up and become malformed, producing an 
effect similar to that of the fungus causing the disease known as 'club-root.' In two or three weeks the maggots become full-fed (a), and they change to the pupa state within hard brown puparia (b), to. emerge some days afterward as adult flies. There are probably three or four broods each season, and the insect apparently hibernates in each of its three. later stages. These insects infest turnips and rutabagas as well as cabbage, and some entomologists consider the Radish Maggot as being also of this species.

Remedies.—Satisfactory remedies for this insect are few and far between. European writers recommend that coal dust be scattered around most of the plants, leaving one occasionally without the dressing to attract the flies to it for egg-deposition, and then destroying the unprotected plants together with the insects about their roots. Dr. Riley has suggested that ashes or slaked lime will probably answer the purpose as well as the coal dust. As some of the larvæ or pupæ appear to pass the winter upon the old roots, it is advisable to pull up and burn such plants in autumn. Probably the most practicable remedy is that of always putting new plantations of cabbages some distance from where they were grown the previous year. This has been found in practice to give good results. The flies are sluggish, and apparently do not scatter far from where they reach maturity. The maggots may be destroyed by pouring a small quantity of kerosene emulsion about the 
infested roots. In some localities the growers search regularly about the bases of the stems for the bunches of whitish eggs, and claim it to be the best method of checking the injuries of the pest.

\section{INJURING THE LEAVES.}

\section{The Imported Cabbage Worm.}

Pieris rapx.

This insect was imported into America from Europe about 1857 , since when it has become exceedingly destructive over a large portion of the United States and Canada. The adult is a common white butterfly, the female of which has two black spots upon each of the front wings (Fig. 100,c), while the male (Fig.

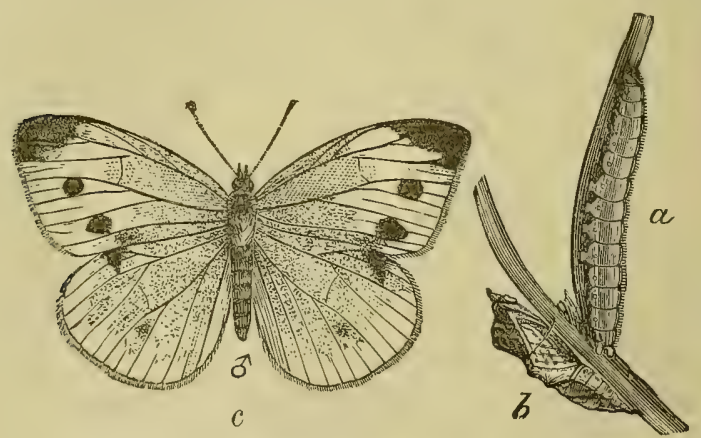

Fig. 100. Imported Cabbage Worm: $n$, larva; $b$, chrysalis; $c$, female butterfly.

101) has but one. The former deposit, singly or in clusters of two or three each, small, fusiform, yellowish eggs upon the cabbage leaves, which soon hatch 
into little, green larvæ that feed upon the substance of the foliage. In about two weeks they become full grown (Fig. 100, a), when they generally leave the cabbage plants, and, finding some Fig. 101. Imported Cabbage Butterfly. IIale suitable shelter-beneath a board or under the coping of a fence-change to chrysalids (Fig. 100, b). They remain in this condition about ten days, when they emerge as butterfles, to lay eggs for another brood of worms. The winter is passed in the chrysalis state. There are several generations of larvæ each season, the number varying with the climate and latitude.

This insect has numerous natural enemies with which to contend. The larvæ and pupæ are preyed upon by certain parasitic and predaceous insects, and the butterflies are often captured by insectivorous birds, as well as by a predaceous bug, known to entomologists as Phymata wolffi. The larvæ are often destroyed by thousands by a bacterial disease - a sort of insect cholera-that has lately aided greatly in checking the injuries of this pest.

There are two or three species of native cabbage worms - notably the Southern Cabbage Butterfy (Pieris protodice) and the Potherb Butterfly (P. olerccea) - closely related and similar to this Imported Worm, that were formerly quite injurious to cabbage, 
but since the introduction of the alien species they have been largely crowded to the wall, and are seldom destructive.

Remedies.-Pyrethrum (insect powder or bubach), hot water, and kerosene emulsion are the substances that can most successfully be used in fighting the Imported Cabbage Worm. The insect powder may be diluted with six or eight times its bulk of flour, and dusted on with a powder-gun or bellows, or it may be mixed with water in the proportion of one ounce to four or five gallons of water, and sprayed upon the plants. Dr. Riley gives preference to hot water as a remedy for this insect. He states that "every worm visible upon the cabbages may be killed by the use of hot water at the temperature of $130^{\circ}$ Fahrenheit. The water may be boiling hot when put in the watering-can, but it will not be too hot when it reaches the cabbage leaves." Kerosene emulsion can advantageously be used when the plants are young, though there would appear to be danger of tainting the heads if applied to the fully developed plants. Whichever method of treatment is adopted, it should be carried into practice at frequent intervals, thus keeping the worms well in check. If the plants are dusted with insect powder once a week during the time that the worms are present, they will cause little or no trouble. For applying the water mixtures of pyrethrum, or kerosene emulsion, either the Excelsior or Field knapsack sprayers appear to be well adapted; while on a larger scale the Nixon potato sprayer might be utilized. 


\section{The Cabbage Plusia.}

Plusia brassicæ.

This insect, illustrated in its three later stages at Fig. 102, has been known for years to do serious injury to a number of garden crops. While it is especially injurious to cabbage, it also attacks celery: turnip, tomato, clover, cauliflower, lettuce, dandelion, dock, and several other plants. The adult (shown at upper part of Fig. 102) is a handsome, dark-grey moth, with a silvery spot near the middle of each front wing. The females deposit their pale, greenishyellow eggs, singly or in clusters, on the cabbage

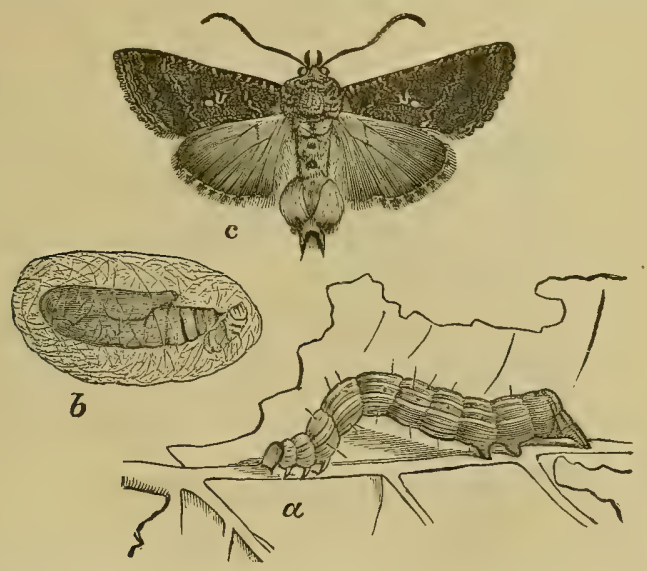

Fig. 102. Cabbage Plusia : $a$, larva; $b$, pupa in cocoon; $c$, moth.

leaves, usually on the upper surface. The larvæ soon hatch and devour the leaves as they develop, boring small, irregular holes in the cabbage head. 
When full grown (a), they are about an inch long, of a general pale-green color, with longitudinal lighter stripes: the head is small, and the body gradually enlarges from the front backward. In motion the body assumes a looping position, as shown in the figure. The full-grown larva spins a slight, white, silken cocoon on the cabbage leaf, generally on the lower surface, and within this changes to a brownish pupa, (b). In a short time it emerges as a moth. At the South, where this insect is ordinarily more destructive than at the North, there are several broods each season. The moths are nocturnal or crepuscular, but in cloudy weather are sometimes seen flying during the day.

The larvæ of the Cabbage Plusia are subject to the attacks of many enemies: they are devoured by birds, destroyed by certain parasitic insects, and often become the victims of a fungous disease.

Remedies.-This insect is more difficult to destroy than the Imported Cabbage Worm, but it will succumb to pyrethrum if not diluted with more than three times its bulk of flour, and may also be killed with the kerosene emulsion applied in a spray.

\section{The Zebra Caterpillar.}

Ceramica picta.

This caterpillar is at once distinguished from other larvæ feeding upon cabbage by the brilliant yellow and black markings upon its body. It originates from small, spherical eggs, laid in clusters upon the 
cabbage leaves by a handsome, purplish-brown moth (Fig. 103, b), that appears early in summer. At first the larvæ are very dark, and feed together gregariously, but as they develop they become lighter colored, and disperse over the plant. When disturbed they roll up and drop to the ground. They become full grown $(a)$ in three or four weeks, when they are about two inches long, with a wide, longitudinal, relvet-black stripe upon the middle of the back, and

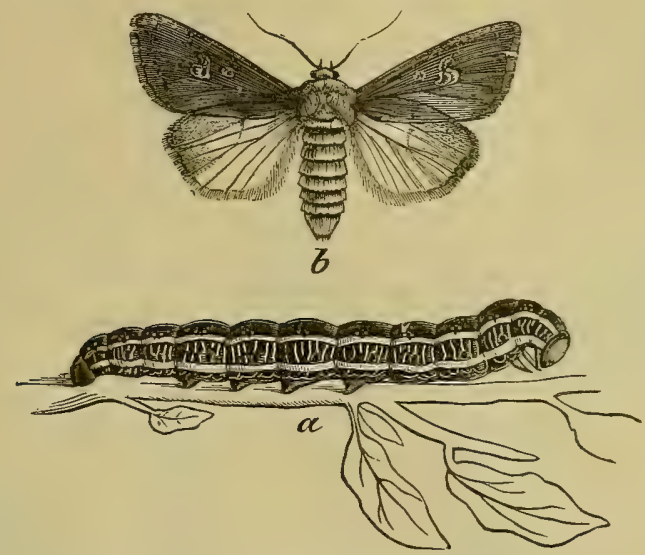

Fig. 103. Zebra Caterpillar: $a$, larva ; $b$, moth.

two bright yellow stripes upon each side, which are connected by fine, yellow, transverse lines. The caterpillars now construct, slightly beneath the soil surface, loose cocoons composed of particles of earth fastened together by silken threads, within which they change to pupæ. About a fortnight later the moths emerge, and deposit eggs for a second brood of 
larve, which develop early in autumn, pupating before winter, and hibernating within their cocoons.

Remedies._- When young the larvæ are congregated together upon one or a few leaves, and may then easily be checked by hand-picking. Later they are open to destruction by the application of hot water, insect powder, or kerosene emulsion.

\section{The Wavy-striped Flea-beetle.}

\section{Phyllotreta vittata.}

This little pest does not by any means confine its depredations to the cabbage, but attacks turnip, mustard, radish, and various other plants as well. It is represented magnified at Fig. 104, b, and is a small, shining black beetle, one tenth of an inch long, with a broad, yellow, wavy, longitudinal stripe on each wing-cover. It feeds upon the surface of the leaf, gnawing out little pits. The females deposit their minute, oval, whitish eggs upon the roots of various cruciferous plants, such as radish, cabbage, turnip, etc., and the larvæ which hatch from them feed upon these roots, sometimes doing serious damage in
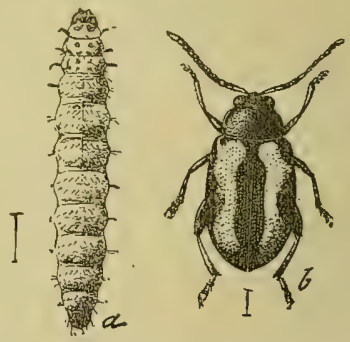

Fig. 104. Wavy-striped Flea-beetle: $a$, larva; $b$, beetle.

this way. The full-grown larva (Fig. 104, a) is about one-fourth of an inch long, with a yellowish-white body, and brown head. There appear to be two or more broods each season. 
Remedies.-Tobacco powder is the best remedy for these little pests. If applied freely to the plants, it will drive them array. In seasons when the beetles are not too thick, dusting the plants with dry, unleached wood ashes, or lime or plaster, will also keep them off, and tobacco decoction is a good remedy.

\section{Cabbage Cut-worms.}

The cabbage is subject to attack by nearly a dozen species of cut-worms, nearly all of which, however, are similar in habits and history, and may well be treated of collectively. They are all larvæ of medium-sized, night-flying moths, and are rather thick, naked worms of the general form of Fig. 105, $a$. They curl up when disturbed. The eggs are deposited generally on the branches of trees and shrubs, the larvæ descending to the ground in search of food as soon as hatched. Most of them. feed upon grass or clover when young, becom-

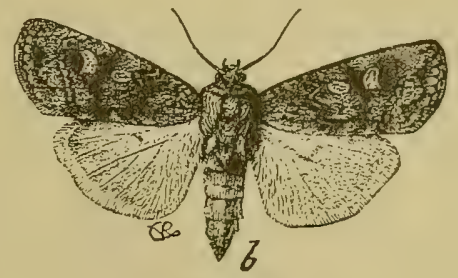
ing, about half grown by winter time, when they seek the shelter of some log or stone, or burrow into the soil. Here they hibernate, and in spring come forth in search of food. They now attack a variety of young plants, biting off the stems and feeding 
upon the leaves. Cabbages, tomatoes, turnips, squashes, melons, and various other garden vegetables are all liable to their attacks.. They become full grown in spring or early summer, when they pupate beneath the soil surface, and three or four weeks later emerge as moths. The larva $(a)$ and moth (b) of the Variegated Cut-worm (Agrotis saucia) are represented, natural size, at Fig. 105. Some species have two or more broods each season, while others have but one.

Cut-worms are especially likely to do damage in fields and gardens close to grass-lands, and to crops immediately following grass.

Remedies.-Of the dozens of methods of destroying cut-worms, there are three which are of special merit. They are:

(1). The poison method. This consists in killing off the worms before the crops are planted, by strewing over the soil bunches of fresh clover or cabbage leaves, which have been treated with Paris green or London purple, either by dipping into a solution of the poison, or dusting it on dry. The half-grown worms prowling about in search of food eat of the baits thus set, and are destroyed before doing any harm. This method has proved a practical success with many gardeners; and is well worth trying where there is likely to be trouble from these pests. Of course care must be taken that chickens or stock do not get at the poisoned leaves.

(2). Using boards as traps. This method consists in placing boards on the ground in and about the 
garden, and collecting in the morning, the worms that will congregate beneath them during the night.

(3). Digging out the worms where plants have been cut off. This is practicable in most gardens, and is well worth doing, thus preventing further damage.

\section{The Harlequin Cabbage-bug.}

\section{ITurgantia histrionica.}

The injuries of this insect were first noticed in Texas and other states at the far South, but it has gradually spread northward, especially along the Atlantic coast, until now it is seriously injurious as far north as Delaware. It feeds upon a variety of cruciferous plants, including cabbage, radish, mustard, turnip, etc. The insect "derives its name from the gay, theatrical, harlequin-like manner in which the black and orange-yellow colors are arranged upon its body" (Fig. 106, a, b, f, g). According to Dr. G.

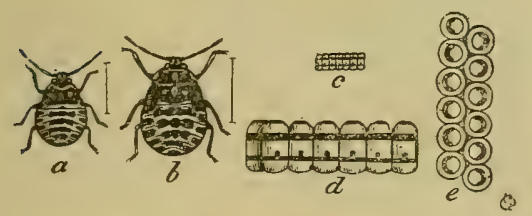

Lincecum, in Texas, "the perfect insect lives through the winter, and is ready to deposit its eggs as early as the 15 th of

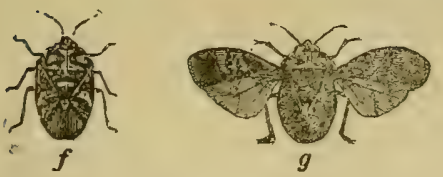

Fig. 106. Harlequin Cabbage-bug: $a, b$ nymphs; $c$, eggs ; $f$, adult ; $g$, adult with wings extended-all natural size; $d$, eggs, side view; $e$, eggs, view from above, $-d, e$, enlarged.
March, or sooner if it finds any cruciform plant large enough. They set their eggs $(c, d, e)$ on end in two rows, cemented together, mostly on the under side of the 
leaf, and generally from eleven to twelve in number. In about six days in April (four days in July) there hatches out from these eggs a brood of larvæ, resembling the perfect insect, except in having no wings. This brood immediately begins the work of destruction by piercing and sucking the life-sap from the leaves, and in twelve days they have matured. They are timid, and run off and hide behind the first leaf stem, or any part of the plant that will answer the purpose. The leaf that they puncture soon wilts, like the effects of poison, and soon withers. Half a dozen grown insects will kill a cabbage in a day." At the South there are several broods each season.

Remedies.-Hot water, kerosene emulsion, and pyrethrum are the substances chiefly recommended for the destruction of this pest. Clean cultivation and the burning of all rubbish are important preventive measures. In spring and autumn many of the bugs may be trapped by laying cabbage or turnip leaves between the roms : the insects will harbor under these, and may be collected each morning. It is especially important to destroy the earlier broods of this pest, because otherwise it increases so rapidly as to be almost unconquerable.

\section{The Cabbage Aphis:}

Aphis brassicx.

Next to the Imported Cabbage Worm this species is, perhaps, the most injurious insect enemy of the cabbage; and it also infests various other cruciferous 
plants, including turnip, radish, Field Cress, and

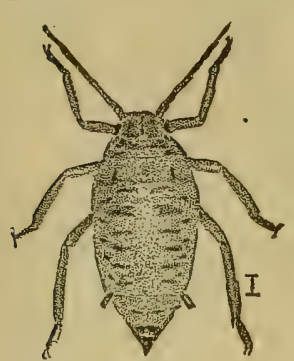

Fig. 107. Cabbage Aphi oviparous female. Magnified. Shepherd's Purse. It appears to have been originally an European species, and was probably introduced into America at an early date. It is probable that it is now found in this country wherever the cabbage is extensively grown.

The Cabbage Aphis is a small, greenish insect, generally corered with a whitish, mealy coating, that occurs in great numbers on the leaves and in the heads. During the summer months it reproduces

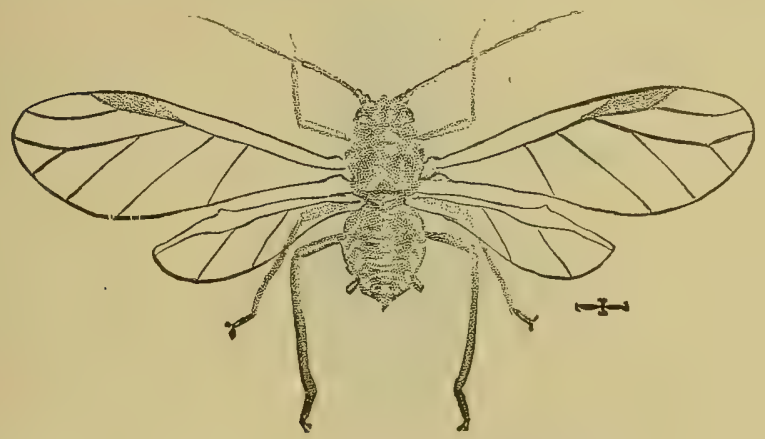

Fig. 108. Cabbage Aphis: male, magnified.

viviparously, but in autumn true males (Fig. 108) and females (Fig. 107) are developed, eggs being deposited by the latter upon the cabbage leaves.

Remedies.-Kerosene emulsion is the most effective insecticide that can be used against this insect. 
It may readily be applied to cabbage from a knapsack sprayer, like the one manufactured by the Field Force Pump Company, or the Excelsior Sprayer. As the insect winters over in the egg state upon the cabbage leaves, it is advisable to destroy all the remains of the crop in autumn, not leaving the 'beheaded ' plants in the field all winter, as is too often done.

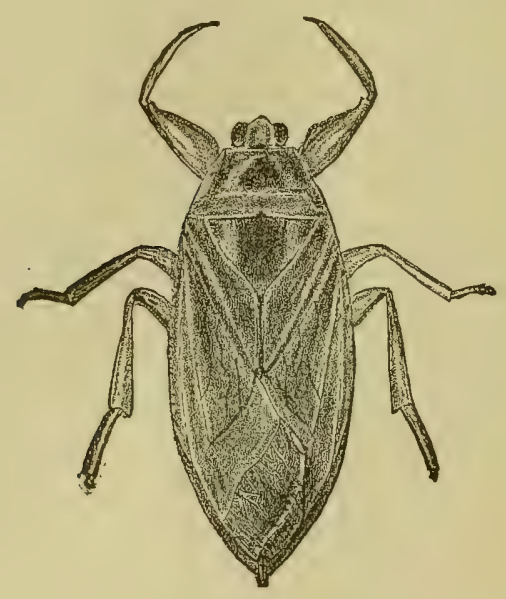




\title{
INSECTS AFFECTING THE ONION.
}

INJURING THE BULBS.

\section{The Onion Maggot.}

\author{
Anthomyia ceparum.
}

The Onion Maggot is closely related to the Cabbage Maggot, to which it is similar in life-history and habits. The adult is a two-winged fly, which deposits its small, white eggs on the bulbs or lower leaves of the young plants. About a week later the eggs hatch into young larvæ that bore into the bulbs, absorbing the succulent substance. When one bulb is consumed they pass on to another. The full-grown larvæ are nearly half an inch long, of a dull white color, ard pointed at the mouth or front end. They complete their larval growth in about two weeks, and then leave the onions and enter the surrounding earth, where they change to the pupa state within brown puparia. A fortnight later the flies emerge to lay eggs for another brood.

Remedies.-Professor Cook states that the most practical method of preventing the injuries of this insect is to change the position of the onion bed every year, putting it each time some distance from where it was the preceding season. Wherever the conditions are such that this can be done, this is probably the best preventive measure. Miss Ormerod reports that if the bulbs are kept covered with earth they are not attacked by the maggots. 


\section{INSECTS AFFECTING ASPARAGUS.}

\section{The Asparagus Beetle.}

Crioceris asparagi.

This insect was introduced into America from Europe about thirty years ago, and at once became very destructive to asparagus in the region of $\mathrm{New}$ York City. It has since spread over a large area, being reported in 1890 as far west as Ohio. According to Professor Comstock its life-history may be bricfly summarized as follows: "Upon the appearance of the plants in early spring, and just before the cultivators are ready to begin bunching for the early market, the beetles come forth in great numbers from their hibernating quarters-under sticks, stones, rubbish, and especially under the splinters of wood on fences and under the scaly bark of trees-and commence gnawing the tops of the young plants. They pair and lay their eggs very soon. The eggs (Fig. $109, a)$ are oval and are placed endwise on the plant, usually in rows of two to seven. In from seven to ten days the young larvæ begin to make their appearance. In form they bear a close resemblance to the Colorado Potato Beetle larvæ. The general color is grayish olive with shining black head and brown legs. When full grown (b) they measure a little over three-tenths of an inch." The larvæ feed upon the outer bark of the asparagus, and 
develop in about two weeks from the time of hatching. They then descend to the earth where, slightly beneath the surface, or under rubbish above the surface, they change to pupæ. About ten days later they emerge as beetles to feed upon the plants and deposit eggs for another brood. The beetles $(c)$ are very pretty little creatures, with head, legs and antennæ of a shining metallic greenish-black hue, a red dishbrown thorax ornamented with two conspicuous black spots, and lemon-yellow wing covers, marked with a longiitudinal black stripe and a transverse black band. There are two or more broods eachi Fig. 109. Asparagus Beetle: $\alpha$, season.

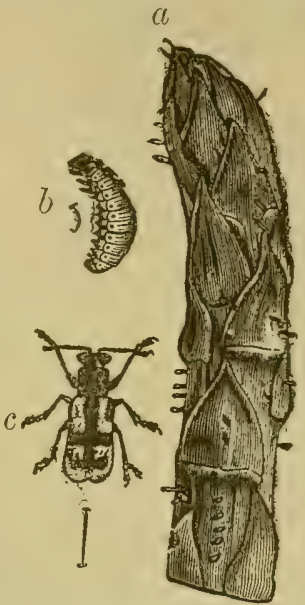
tle: $b$ and $c$ magmified.

Remedies.-The plan most successfully adopted. by Long Island gardeners to prevent the injuries of this insect is that of destroying by hoeing or other cultivation, all volunteer growth of asparagus, leaving only the shoots designed for market for the beetles to lay their eggs upon. These shoots are cut and removed so often that there is no opportunity for the eggs to hatch in the field, and thus the increase of the pest is effectually prevented. The beetles are greedily devoured by domestic fowls, and in kitchen 
gardens these can sometimes be advantageously used against them. Of the artificial insecticides, pyrethrum will probably give the best results. In small patches it has been found practicable to rub off the eggs from the growing shoots.

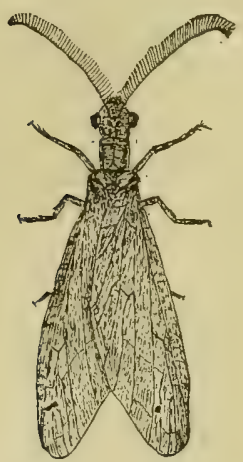


PART V.

INSECTS AFFECTING

CEREAL AND FORAGE CROPS. 


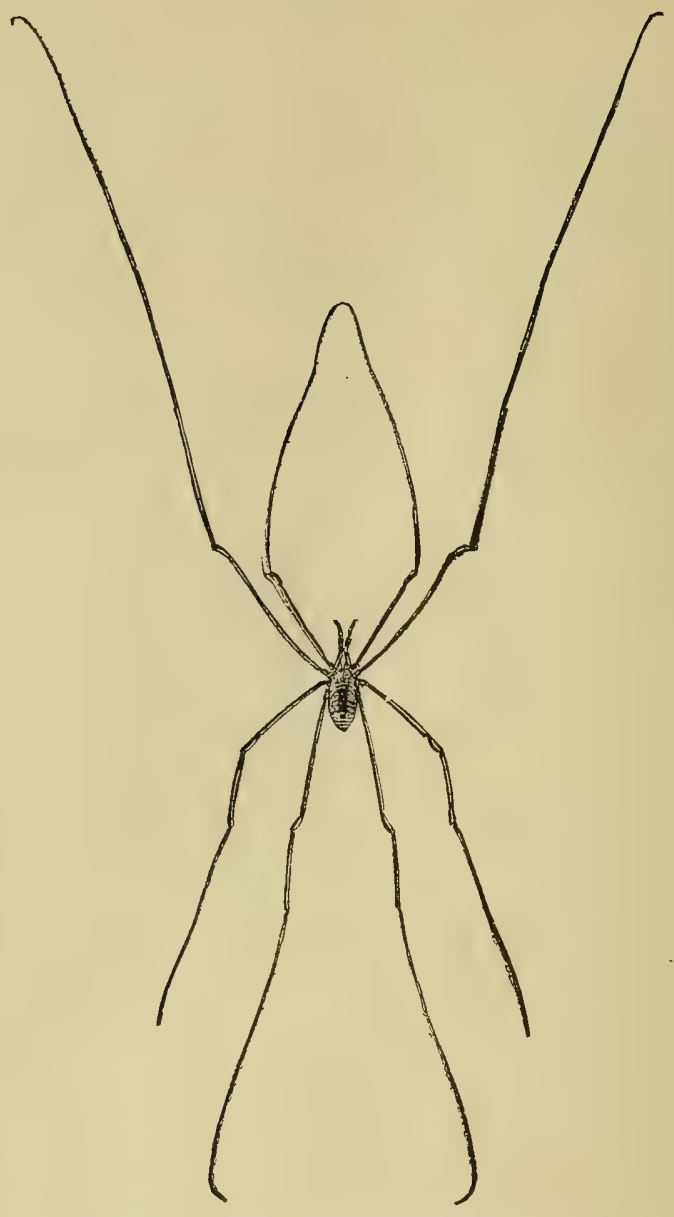

PLATE VI.-The Striped HARVEST-SPider. 


\section{INSECTS AFFECTING INDIAN CORN.}

\section{INJURING THE ROOT.}

\section{The Corn Root-aphis.}

Aphis maidis?

This is a small, bluish-green aphis, or louse, which occurs on the roots of corn, from the time it comes up in spring until it is cut in autumn. Its general

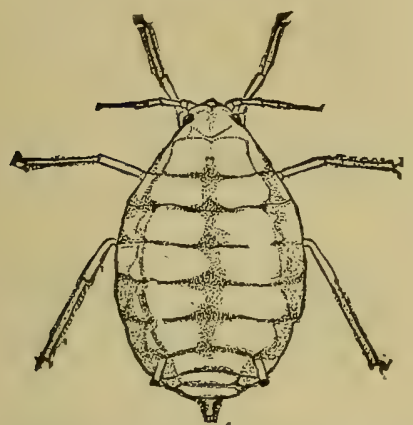
form, when magnified, is well shown at Fig. 110, which represents a closely related species, the Apple Aphis. There are two forms found upon the roots, one having wings and the other not, the latter being much the commonest. Both forms Fig. 110. Apple Aphis. Magnified. are always attended by the common, small, brown ant (Lasius aliemus), which cares for them as tenderly as it does for the eggs and young of its own species. Eggs are laid by the aphides, during September and October, in the subterranean galleries of the ants, and are collected by the latter and cared for all winter. In spring, when the lice are beginning to hatch, the ants tumnel about the roots of corn, or various weedy plants, and transport the little aphides to them. The lice feed upon the sap of the plant, sucking it through their 
tiny beaks, and multiply viviparously or by giving birth to living young. They continue developing in this way until fall, when the egg-laying brood is produced.

The presence of these lice upon the roots can easily be determined by carefully pulling or digging up plants supposed to be injured. The aphides, if present, will be seen crowding the roots as small, bluishgreen particles. The affected plants generally appear yellow and sickly, growing slowly or not at all.

Remedies.-A judicious rotation of corn with other crops is the only practicable preventive measure that has as yet been suggested.

\section{The Western C'orn Root-worm.}

Diabrotica longicornis.

In Illinois, Kansas, and other western States, the roots of corn are frequently eaten off, during June
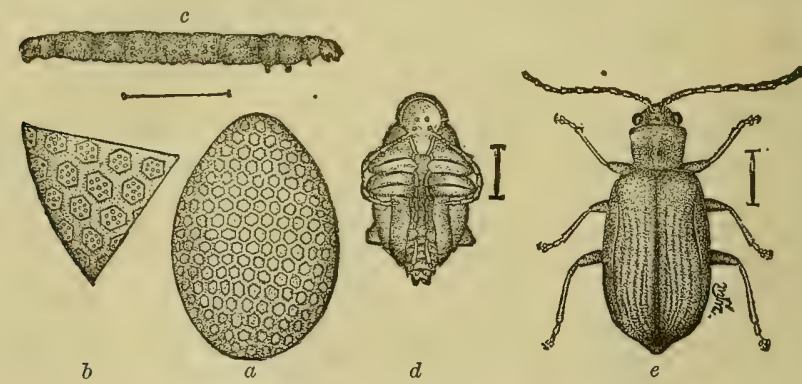

Fig. 111. Corn Root-worm: $a$, egg; $b$, small section of egg, greatly magnified; $c$, larva ; $d$, pupa; $e$, beetle. Magnified.

and July, by a slender, white worm, a little less than half an inch long, and about as thick as a common 
pin. It has a small, brown head, and three pairs of short legs near the front end, at shown at Fig. 111, c. It attacks the roots from the outer ends, burrowing beneath the surface, and eating its way toward the stalk. Shortly after midsummer it becomes full-fed, and, deserting the root, pupates in the surrounding soil. The pupa $(d)$ is about one-fifth of an inch long, and white in color. A few days later it again transforms, and emerges as a grass-green beetle of the form represented at Fig. 111, e. "The beetle climbs up the stalk," according to Professor Forbes' account, "living upon fallen pollen, and upon the silk at the top of the ear, until the latter dries, when a few of the beetles creep down between the husks and feed upon the corn itself, while the other's resort for food to the pollen of such weeds in the field as are at that time in blossom. In September and October the eggs (a) are laid in the ground, upon or about the roots of the corn, and most of the beetles soon after disappear from the field." They feed for awhile upon various fall flowers, and gradually die off, the winter being passed by means of the eggs deposited in the corn ground. The eggs hatch the following spring.

Remedies.-As the eggs of this insect are deposited in autumn in corn ground, rotation of crops furnishes a simple method of preventing its injuries. If the land is planted to some other crop the year following, the larvæ, on hatching, will be deprived of suitable food, and consequently will perish. 


\section{The Southern Corn Root-worm.}

\section{Diabrotica 12-punctata.}

The three later stages of this insect are represented at Fig. 112. The larva $(a)$ is a slender, whitish worm, about half an inch long, resembling the Western Corn Root-Torm, to which, in fact, it is closely related. It feeds promiscuously upon the roots and

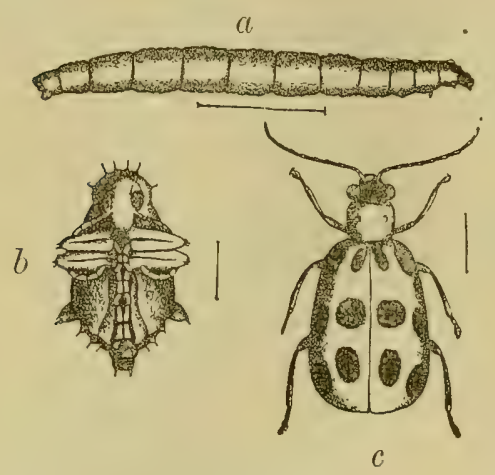

Fig. 112. Southern Corn Root-worm: $\alpha$, larpa ; $b$, pupa; $c$, beetle. Nagnified. base of the stalk of corn, pupating in the soil about the roots, and emerging shortly afterwards as a yellow beetle with 12 black spots upon the back $(c)$. There are two broods each season, eggs for the first brood being deposited by the female beetles in spring about the roots of young corn, and the second brood of larræ generally developing upon the roots of certain wild plants, especially those of the Composite family. The insect hibernates as an adult, and the beetles feed upon a great variety of vegetation, often, doing serious damage to cucumbers, squashes, melons, and other garden vegetables.

Remedies.-No practicable remedy has yet been found for this insect in its corn infesting stage 


\section{Wireworms.}

\section{Elateridx.}

Sprouting kernels of corn are often attacked by a hard, slender, yellowish worm, commonly called the wire-worm, which eats out the substance of the seed or attacks the young roots. These are the young or larve of various species of brown, flattened, elongate beetles, called click beetles, snapping bugs, or "skip jacks," on account of their habit of snapping upward in the air when placed on their backs. Eggs are laid by these beetles in grass-lands especially, and the larve that hatch feed for several years upon the roots of rarious plants. They finally transform during autumn in hollow cells in the earth into pupæ, and shortly afterwards again change to beetles. They do not, however, leave their pupa cells at once, but remain in them until the following spring. Professor J. H. Comstock has found that in breeding cages, if these cells be broken open in fall the beetles die.

Remedies.-On account of the fact just mentioned, fall plowing has been recommended as a preventive of wire-worm injury, the supposition being that the cells in which the beetles are resting will thus be broken open and the insects perish. Anotber method which has been recommended by leading entomologists is that of sowing corn which has been soaked in arsenic water over the field, about ten days before the crop is planted, and harrowing it in. The wire-worms attacking the poisoned, corn will be killed. 


\section{INJURING THE STALK AND LEAVES.}

\section{The Stalk-borer.}

Gortyna nitela.

The terminal leaves of growing corn plants are sometimes observed suddenly to wilt and wither. If pulled upward it will be seen that they have been cut off inside the stalk, where there will generally be found a striped, b r o w n worm, of the form represented at Fig. 113, 2. This is the stalk-

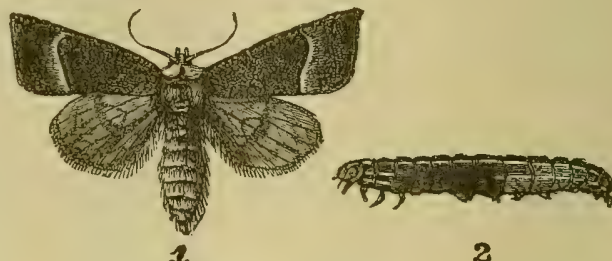

Fig. 113. Stalk-borer: 1, moth; 2, larva.

borer, so called, because of its habit of burrowing the stalks of various plants, such as the potato, tomato, cocklebur, etc. It hatches from an egg laid by a brown moth (1), and pupates beneath the soil surface. The moths appear late in summer or early in autumn, and the insect apparently hibernates in its adult condition.

Remedies.-The only general measure that can be recommended against this insect is that of clean farming. The species largely develops in wayside weeds, and consequently these should be destroyed. Wherever the larvæ are found at work they should, of course, be killed. 


\section{Cut Worms.}

\section{Noctuidx.}

The general life-history of the various species of cut worms has already been described on page 197 . These pests are especially liable to injure com planted on sod land, but such damage may sasily be prevented by using the poison traps described in connection with remedies for cabbage cutworms (p.197). The field to be planted should be strewn with poisomed clover or grass, or cabbage leaves, before the crop is put in, although if not done then the baits may be placed between the rows afterwards.

\section{The Garden Web-worm.}

\section{Eurycreon rantalis.}

This insect occasionally becomes destructive over a wide area, and damages a great variety of crops, although corn usually suffers most. The adult is a small, grayish moth (Fig. 114,f), expanding about three-quarters of an inch, the females of which deposit their eggs upon the leaves or stems of various plants. Soon after hatching the young larvæ begin to spin a protective web, which is enlarged as Fig. 114. Garden Wel-worm: $a$, larra the insects derelop. Be- $d$, pupa, both twice natural size; $f$, the insects develop. Be- moth, slightly enlarged. neath this they feed upon the foliage, eating at first 
only the surface substance, but as they grow older they devour the whole leaf. The larva become full grown in about a fortnight, when they spin thin, brownish cocoons on the ground, and change to pupæ, to emerge ten days or two weeks later as moths. There are two or three broods each season.

Remedies.-Spraying or dusting infested plants nith London purple or Paris green is the most practical remedy for this insect that has yet been suggested.

\section{The Corn Aphis.}

Aphis maidis.

The leaves and stalks of corn are often infested by colonies of a small bluish aphis or plant-louse, the majority of which are wingless, and the rest winged. This is the Corn Aphis. It has been for a long while considered the aerial form of the Corn Rootlouse, but the latest investigations indicate that the two are distinct species.

The full life-history of this insect is not known. It is probably the summer form of some species that passes the fall, winter, and spring upon a tree or shrub. The winged viviparous females appear upon the corn early in summer and start colonies of young lice which develop rapidly and continue to multiply viviparously until the approach of cold weather in autumn. Then a winged brood appears, and leaves the corn, migrating, doubtless, to some other plant. But where it goes, and where the winged females that start the colonies in early summer come from, is not known. 
These plant-lice have many natural enemies with which to contend. Chief among these are certain minute four-winged parasitic flies, the lady-beetles, and harvest-spiders or daddy-long-legs. The first named of these enemies are true parasites, developing within the bodies of the aphides, but the rest are predaceous insects. There are several species of ladybeetles that, both in their larval and adult states, prey upon the Corn Aphis. An idea of their general appearance may be gained from Fig. 115, which
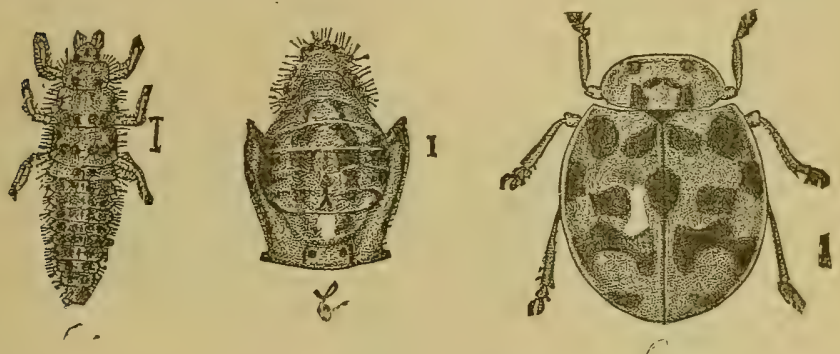

Fig. 115. Twenty-spotted Lady-beetle: $a$, larra; $b$, pupa; $c$, beetle. represents the three later stages of one of the smaller species-the 'Trenty-spotted Lady-beetle (Psyllobora 20-maculata). It is probable, also, that great numbers of the aphides are destroyed by the harvestspiders which abound upon corn plants during summer. One of the commonest of these-the Striped Harvest-spider-is shown, matural size, at Plate T'I.

Remedies.-It seldom becomes necessary to resort to artificial remedies for this insect. While it could readily be destroyed with kerosene emulsion, the application generally mould not pay in field cuiture. 
218 INSECTS AFFECTING THE INDIAN CORN.

\section{INJURING THE EARS.}

\section{The Corn-worm or Boll-worm.}

Heliothis armigera.

In the Southem States this insect is called the Boll-worm because it feeds upon cotton bolls; but at the North it is known as the Corn-worm from its habit of eating the kernels of ripening com. On this account it has come to be recognized as one of the

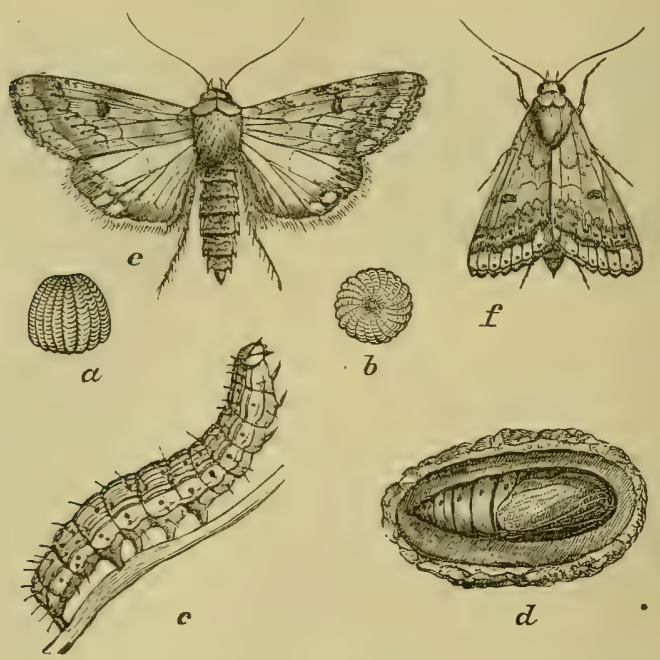

Fig. 116. Corn-ाrorm: $a, b$, eggs, side view and top view, magnified; $c$, larva; $d$, pupa, in cocoon; $e$, moth with wings expanded ; $f$, moth with wings elosed.

most vexatious insect enemies of this crop; and no thoroughgoing remedy that is practicable on a large scale has as yet been devised for it. The 
parent is a good-sized, greenish-yellow moth (Fig. $116, e, f$ ) with a conspicuous black spot near the middle of the front wings, and various olive or rufous markings. These insects deposit their egg's anong the silks of the young ears. The larræ soon hatch and eat through the husk to the succulent kernels beneath, which they derour greedily for sereral weeks, gnawing irregular chamnels along the cob. When full-grown (c) they are an inch and a half long, of a pale green or dark brown color, orramented with longitudinal darker stripes. They now leave the ear, and, entering the soil a few inches, form loose cocoons of silk with particles of soil intermixed, within which they change to chestnutbrown pupæ $(d)$, emerging about a fortnight later as moths. At the north there are two broods, a third one occasionally dereloping in exceptionally loug seasons, while at the south there are four or fire. The first brood is especially likely to infest early sweet corn in gardens.

Remedies.-Hand-picking is the only remedy that has been suggested, except that of catching the moths by light-traps. The silk of infested ears shors the presence of the larra by being prematurely dry or partially eaten, and the larvæ may be readily found and crushed. In garden patches of sweet corn, at least, this method is worth using. In fields, fall plowing will help to reduce the amount of damage by destroying the pupæ, either directly, or indirectly by exposing them to the reather and birls. 


\section{INSECTS AFFECTING WHEAT.}

INJURING THE STALK AND LEAF.

\section{The Hessian Fly.}

Cecidomyia destructor.

This is one of the oldest and best known insect pests of American agriculture. It has ranked as a destructive species for more than a century, and has probably been introduced nearly everywhere that wheat is grown. The adult is a small, two-winged, mosquito-like fly (Fig. 117, d), the females of which deposit their eggs on the upper surfaces of the wheat blades ear-

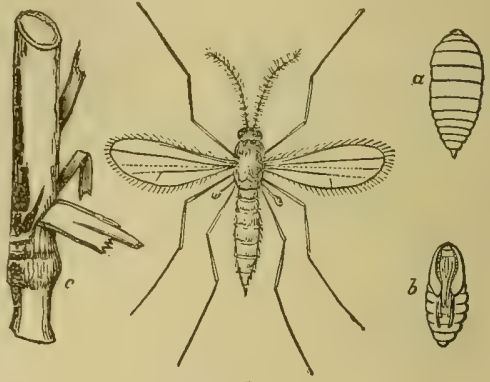

Fig. 117. Hessian Fly : $a$, larva; $b$, pupa ; $c$, injured stem; $d$, fly.

ly in autumn. In a few days the larvæ hatch, and each descends the leaf to the base of the sheath, where it attaches itself, head downwards, to the stalk, and proceeds to absorb the life-sap of the plant. As the latter grows the young larva becomes imbedded in the stalk, where it remains stationary. When full-grown (which occurs in three or four weeks from the time of hatching) the larva is a soft, white, footless maggot of the form represented at $a$. Its outer 
skin now becomes hard and brown, and separates from the rest of the body, although it still surrounds the latter, forming a sort of cocoon, or, as it is more correctly called, puparium, within which the insect changes to a pupa (b). This is the "flaxseed" state, so called because of the resemblance of these brown puparia to flaxseeds.' The winter is usually passed in this condition, and in spring the flies emerge from the flaxseeds to lay eggs for another brood. The larvæ of the fall brood affect the young wheat plants just above the roots, betrreen the stalk and sheathing base of the leaf, but the spring generation are formed a little higher up, at the joints an inch or more alove the soil surface. This second generation completes its transformations before harvest, and there is often, if not always, at least as far north as the latitude of 40 degrees, a third brood, which develops during summer in volunteer wheat; and Professor Forbes has shown that there may occasionally bu even a fourth brood during the year. But the chief damage is done by the fall and spring broods.

There are several species of insect parasites which attack the Hessian Fly, so checking it that in most localities it only occasionally becomes injurious.

Remedies.-The most promising method of preventing the injuries of this insect appears to be that of inducing the flies to deposit their eggs in young wheat, and then destroying it. Where a third brood develops in volunteer wheat this end may be accomplished by turning under this volunteer growth 
when the Hessian Fly larvæ are about half-grown; or in case no such brood develops in the volunteer wheat, a few strips in the field may be seeded to wheat a few weeks before the regular planting time, and the flies will lay their eggs in these, which are afterwards to be plowed under. Thus the main crop of wheat will escape infestation.

\section{The Chinch Bug.}

\section{Blissus leucopterus.}

The Chinch Bug and the Rocky Mountain Locust have long been known as the arch enemies of W'estern agriculture. They have each destroyed millions of dollars worth of property, and have often caused great destitution over large areas. The Chinch Bug
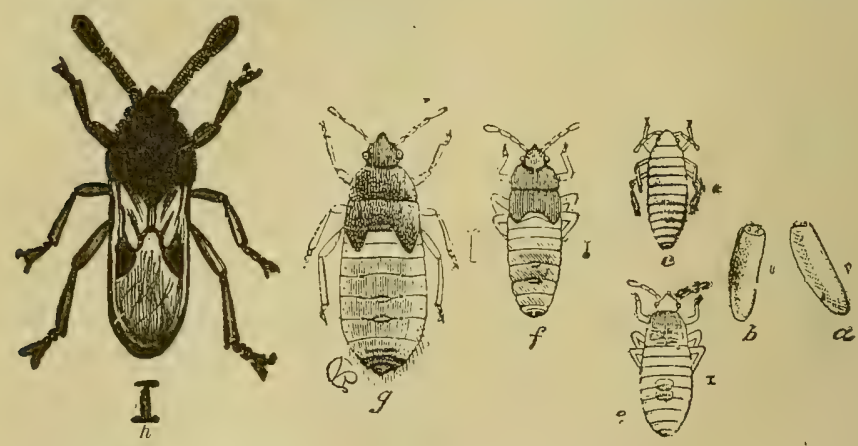

Fig. 118. Chinch Bug: $a, b$, eggs; $c, e, f$ young ; $g$, nymph or pupa; $h$, adult. Magnified.

flourishes best at the South, but occasionally occurs in destructive numbers as far north as New York and Minnesota. Like other injurious insects it is 
subject to periodical uprisings, which usually continue one, two, or three seasons before the various natural checks upon its increase reduce its numbers below the danger line.

The adult Chinch Bug (Fig. 118, $h$ ) is a small blackish insect, slightly less than one-fifth of an inch long, with the legs dark yellow, and their tips black. The young $(c, e, f)$ do not differ in general form from the adults. When first hatched they are pale yellow, but they soon become red: this continues to be the prevailing color until the pupa or last nymph stage $(g)$ is reached. The insect is then grayish or brownish-black. The eggs $(a, b)$ are quite small, being about 0.03 inch in length, and amber colored. Short-winged varieties of the adult Chinch Bugs are sometimes found.

Professor S. A. Forbes has summarized the lifehistory of this insect as follows: "The Chinch Bug passes the winter in the adult winged state (a few black wingless individuals occasionally occurring) under rubbish in, or around the fields, in corn-shocks and straw-piles, under boards and among dead leares in the woods, most abundant, usually, around the edges of the fields and in thickets, and around the borders of woods. From these lurking places such as survive the winter emerge in April and May (possibly sooner, if the season opens early), and, after pairing, lay their eggs, in May and June, in fields of spring and winter wheat, barley, rye, oats and corn -chiefly in wheat and barley-most of the eggs being deposited in or near the ground, on the lower 
parts of the plants. Many of those hibernating around fields sown to wheat and barley make their way in on foot, thus attacking the outer edges first; but others take wing and scatter freely wherever suitable food invites them.

"By July most of the old bugs will be dead, and the new brood will be nearly full-grown,-far ennugh advanced by harrest to abandon the wheat fields for the nearest available food-oats or corn, if these are adjacent—otherwise and more rarely, grass. Making their way in on foot, only the borders of these fields will be at first attacked; but later, by the 1st of August at the farthest, the bugs not already located will begin to fly, and so will become generally disseminated through fields of com. Here the eggs are laid behind sheaths of the lower leaves, and under the protection of this retreat the young hatch and mature, only coming out upon the exposed surfaces of the leares when they become superabundant or when they get their growth. The full-grown bugs fly freely, singly but not in swarms, whenever their food fails them where they are. Rarely we find in the southern part of Illinois some trace of a third brood in a season, the young of these appearing in September in the corn-but these are in too small numbers to have any practical importance. The broods are mainly two, one breeding chiefly in wheat, and the other almost wholly in corn, the adults of the latter brood passing the winter as above described. Each female is believed to be capable of laying about five hundred eggs. 
"The Chinch Bug is practically confined for food to the great family of grasses (Gramineox) which contains all the cereals and grasses, tame and wild. Some of these, however, it feeds upon with reluctance, if at all; and among the ordinary objects of its food it has its very decided preferences. Among the crop plants, wheat, barley and rye, sorghum, broom-corn and Indian corn, millet and Hungarian grass are its favorite foods, with oats clearly second to these; while among the wild grasses, its preference is for fox-tail grass and 'tickle grass' (Setaria and Eragrostis)."

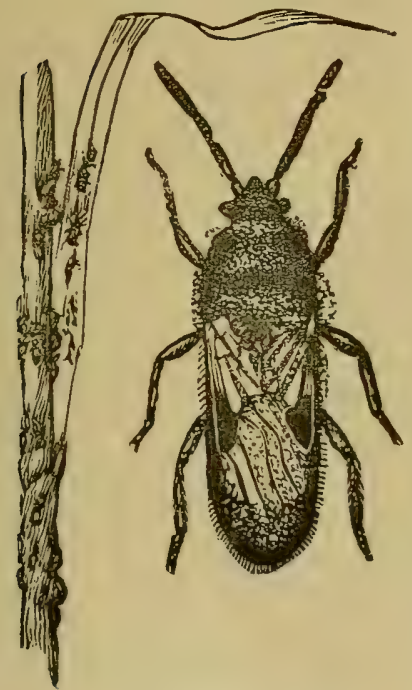

Fig. 119. Chinch Bugs affected by Entomophthora.

The Chinch Bug is subject to the attack of various predaceous insects and vertebrate enemies. Of the former the lady-bugs furnish a good example, and of the latter certain birds, especially the quail, may be mentioned. But these enemies are insignificant so far as concerns their effects upon the numbers of the bugs, when compared with certain fungous or bacterial diseases to which these pests are liable. These diseases sweep them off by the million, and are usually the most potent factor in checking their out-breaks. One of 
these is a fungus that develops on the surface of the bug as a dense white covering. This disease is illustrated at Fig. 119: a number of the dead bugs are shown on a dead wheat stalk at the left, while a single bug, much magnified, covered with the fungus, is represented at the right. This fungus belongs to a genus of plants called by botanists Entomophthora.

Remedies.-Professor S. A. Forbes has divided the remedial and preventive measures applicable to the Chinch Bug into three general classes, namely: (1) Agricultural methods; (2) Barriers against migration; (3) Direct destruction. Under the first of these heads are.included (1) clean farming, especially the cleaning up of refuse that may serve as protection for the bugs during winter, and the destruction of the grass-like weeds upon which they feed; (2) diversified farming and the culture of crops not affected by the Chinch Bug; (3) the temporary abandomment, in corn districts, of small grains, especially wheat and barley; and vice versa, the similar abandonment of corn in small grain districts; (4) heavy fertilization to enable the crops better to withstand attack; (5) the use of surplus seed, or the mixing of clover or timothy seed with small grains when sowed, to produce a heavy growth in which Chinch Bugs do not like to work; (6) plowing under the bugs and their eggs whenever this is practicable.

Under the head of barriers against migration are included: (1) plowing and harrowing at harvest time 
around infested fields, or plowing one or two deep furrows around the field; (2) pouring coal tar along the ground just outside the infested fields and digging holes occasionally on the inside of the tar line for the bugs to fall into; (3) planting strips with crops not subject to injury by the Chinch Bug.

But the most satisfactory class of remedies are those by which the insects are killed outright, and in future outbreaks these will undoubtedly play a much more important part than in the past. The bugs are easily destroyed by kerosene emulsion, and by means of the improved spraying machines now upon the market this substance can advantageously be used against them. During fall, winter and spring, all infested grass lands, and so far as possible, rood lands, should be burned over to destroy the hibernating bugs. Remarkable success has also lately been attained in spreading, artificially, the fungous diseases of the Chinch Bug.

\section{The Grain Aphis.}

Siphonophora avenæ.

This insect occasionally becomes destructive to wheat and oats over large areas. It is a small

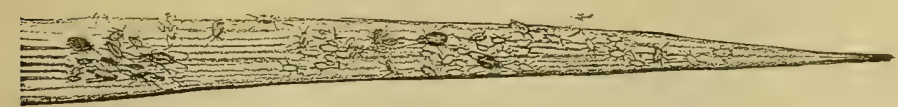

Fig. 120. Oats leaf infested by Grain Aphis.

greenish or brownish aphis, with or without wings, which breeds upon wheat, oats, and various other 
- plants of the grass family. It obtains its food by inserting a pointed beak into the leaf or stem and sucking out the sap. As the wheat gets ripe it migrates to the more succulent oats, and when these ripen goes to various grasses. It brings forth living young, and its rate of multiplication is very great, it

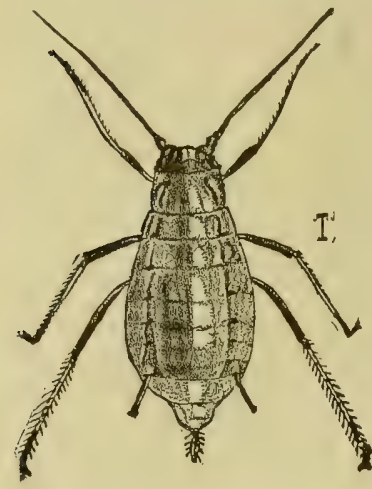

Fig. 121. Grain Aphis: wing less female. Magnified. being estimated that a single louse in spring may become the ancestor of millions before autumn. The true sexed forms have not yet been found. The wingless viviparous female is represented, greatly magnified, at Fig. 121. The injury of these insects is chiefly manifested by the shriveling of the grain in infested fields.

Fortunately this insect has many natural enemies with which to contend. Chief among these are little four-winged parasitic flies, and various species of lady-beetles. These natural enemies are undoubtedly the means of preventing this pest from overrunning grainfields every year.

Remedies._-As yet no practical artificial remedy for the Grain Aphis is known. Kerosene emulsion will destroy them, but the difficulty of reaching them with it when they occur on the under surface of the leaf, makes the remedy hardly practical. We must ordinarily rely upon the weather and its various natural enemies to hold it in check. 


\section{The Wheat Bulb Worm.}

\section{Meromyza americana.}

This insect has attracted the attention of economic entomologists only during comparatively recent years. The adult is a handsome two winged fly (Fig 122, d), having two longitudinal yellowish stripes along its back. The females deposit eggs in the fall on the young wheat plants, and the larvæ, on hatching, feed upon the central portion of the stem, just above the bulb of the plant. They remain

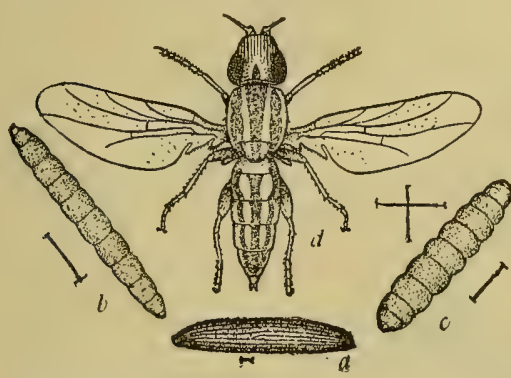

Fig. 122. Wheat Bulb Worm : $a$, egg; $b$, larva: $c$, puparium; $d, \mathrm{fly}$. Magnified. h e r e through the w in te r, becoming full-grown in spring. They are then footless cylindrical larvæ of the form shown at $b$. They pupate in the spring and a fortnight later emerge as flies. After mating, the female flies of this brood deposit eggs for larvæ which work in the straw, just above the last joint, thus cutting off the sap supply from the head and causing it to wither and dry up. These larvæ complete their transformations during July, when they are on the wing as flies. Early in July eggs are deposited by this brood of flies on volunteer wheat, and the transformations of these are completed in time for the adults to lay their eggs in the 
fall wheat. Consequently there are three broods each season. Besides wheat this insect breeds in oats and various grasses.

Remedies.-The destruction of volunteer wheat after the worms have gotten started in it, and the early planting of strips to induce them to oviposit, are the best remedial measures for this insect.

\section{Wheat Joint-worms.}

Isosoma hordei, I. tritici and I. grande.

There are three nearly related species of minute four-winged flies (Fig. 123, $a, b$ ) which deposit eggs in wheat stems that hatch into the so-called joint-

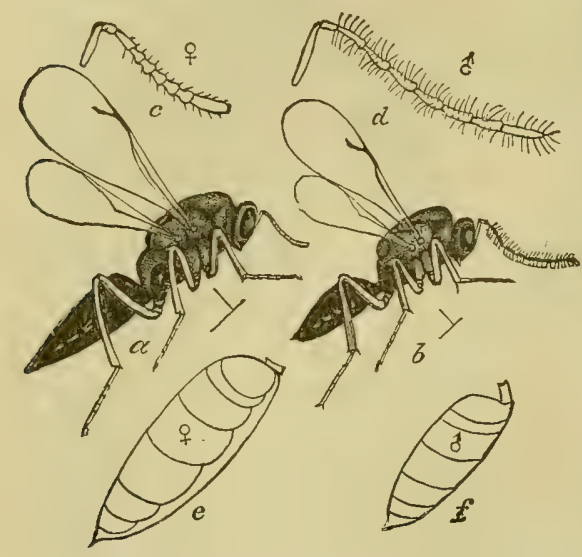

Fig. 123. Joint-worm fly: $a$, female; $c$, antenua of same; $e$, abdomen of same; $b$, male ; $d$, antenna; $f$, abdomen. Magnified. worms. According to Professor F. M. Webster "the females push their ovipositors into the stems of growing wheat and deposit their eggs singly, but often several in each straw. This is done during the early spring, and again during June, in the latitude of central Indiana, the young larvæ feeding upon the substance 
of the stem; but, being secure from ordinary observation, they are seldom noticed. We have found five of these larvæ at work on a single stem. These worms do not usually wither the straw, and the effect of their work is only to be observed in the shorter and more slender stem, shorter heads and smaller and less plump kernels.

"The larvæ are almost invariably found below the upper joint, and hence, by cutting the grain a little high, they can be left in the field, and as they pass the winter as pupæ in the same situation, by burning the stubble any time between harvest and the following March, they can be destroyed. As the adults emerging from the old straws in spring are almost invariably wingless, they cannot travel about very rapidly. And hence changing the grain from one field to another, or rotating the crop, is often quite effectual in keeping them in check. Those adults appearing in June from the growing plants, are provided with well developed wings, and can travel about from field to field with the utmost freedom."

\section{INJURING THE HEADS.}

\section{The Wheat Midge.}

\section{Cecidomyia tritici.}

This insect is closely related to the Hessian fly. The adult is a small, two-winged, yellow or orange colored fly that appears in the wheat fields a few weeks before harvest time, and deposits its minute 
eggs in the crevices between the chaff of the wheat heads. These eggs soon hatch into little footless maggots that attack the young germ or kernel, blasting it. About three weeks later they become full grown : they then leave the heads and enter the ground, where they pupate. There is but one brood each year. Besides wheat, the Midge is said to breed in rye, barley, oats and, possibly, grass.

Remedies.-Early maturing grains are less liable to be infested by this insect than those ripening later. Consequently farmers in regions where it is present plant such varieties early, with general high culture. Many of the insects will be destroyed by the deep plowing of the infested fields.

\section{INJURING STORED GRAIN. \\ The Grain Weevil.}

\section{Calandra granaria.}

There are several species of beetles infesting granaries, the habits and life-histories of which, however, are quite similar. As an example we may take the Imported Grain Weevil, the larva of which is represented at Fig. $124 a$. The parent insect being a small, dark-reddish snoutbeetle (b), deposits its eggs upon the grain. The eggs

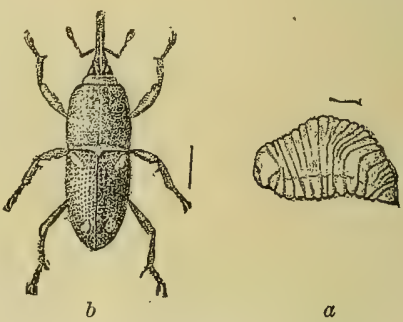

Fig. 124. Grain Weevil: $a$, larva; $b$, beetle. Magnified. 
soon hatch into legless little larvæ that eat out the substance of the kernels, and become full-grown (a) in a few weeks. They then change to pupæ and soon afterwards again transform to adult beetles. There are several broods each season. All sorts of stored grain, such as corn, oats, wheat, barley, etc., are attacked by these insects.

Remedies.-Bisulphide of carbon appears to be the best insecticide to use against grain weevils. The vapor of this substance is poisonous to insect life, and as it is heavier than air it will descend between the kernels of grain, destroying all the weevils which it reaches. Dr. C. V. Riley has lately called attention to the following method of using it, premising with the statement that one and a half pounds of bisulphide is sufficient for each ton of grain: "A ball of tow is tied to a stick of such a length that it can reach the middle of the vessel containing the grain. The tow receives the charge of bisulphide like a sponge, and is at once plunged into the vessel and left there, the mouth or opening of the vessel then being tightly closed. When necessary, the stick may be withdrawn and the charge (of 1 ounce to 100 pounds of grain) may be renewed. The action of carbon bisulphide lasts in ordinary cases six weeks, after which period a fresh charge is required. The bisulphide does no harm to the grain as regards its color, smell, or cooking properties, and the germinating power of most seeds is not appreciably affected, provided that not too much is used, nor its action continued for too long a period." 


\section{INSECTS AFFECTING CLOVER.}

\section{INJURING THE ROOT.}

\section{The Clover Root-borer.}

\section{Hylastes trifolii.}

This insect was originally a native of Europe, from whence it was introduced into America not

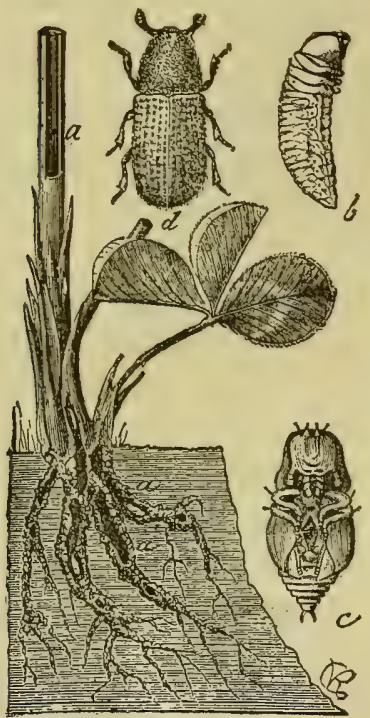

Fig. 12.5. Clover Root-borer: $a$, infested plant $; b$, larva ; $c$, puvery many years ago. The adult is a small, brownishblack, punctate beetle (Fig. $125, d)$, not quite one-tenth of an inch long. It deposits eggs during spring in the crown of the clover plant, four or five eggs being laid on each plant. Shortly afterwards the larvæ hatch and burrow downward through the larger roots $(a, a)$, feeding upon the inner substance, and filling the galleries behind them with their sawdust-like excrement. Late in summer the larvæ become fully grown (b), when they are one-eighth of an inch long, with a whitish body and yellow head. They change to pupæ $(c)$ within the tunneled roots $(a, a)$, and shortly afterwards 
emerge as adult beetles. The species generally passes the winter in the beetle state, but occasionally hibernates as a larva or pupa.

The injuries of this insect are frequently very serious, whole fields of clover often being destroyed. Fortunately its ravages are as yet confined to a comparatively few states, but it is likely to spread over a large portion of the country.

Remedies.-In regions infested by this insect it has been found necessary to rotate the clover crop more frequently than before, mowing the seeded land but once, and pasturing or plowing under the abundant second growth. In this way the crop is turned under before the injuries of the borer become manifest. According to many of the most successful farmers, this frequent rotation is deemed desirable anyhow, so that the insect, in their opinion, is a means of compelling the adoption of an improvement in farm management.

\section{INJURING THE LEAVES}

\section{The Clover Leaf-beetle.}

Phytonomus punctatus.

Like so many other of our injurious insects, the native home of this species is Europe, from whence it was probably introduced into America many years ago, although it has only been seriously destructire here for a comparatively few years. It was first 
noticed in New York State, and as yet has not spread to very many other states, although it is likely to do so.

Dr. C. V. Riley; who first worked out the American life-history of this species, has admirably illustrated this insect and its injury at Fig. 126. The adult $(i, j, k)$ is a dark brown snout-beetle, not quite half an inch long, which feeds greedily upon the

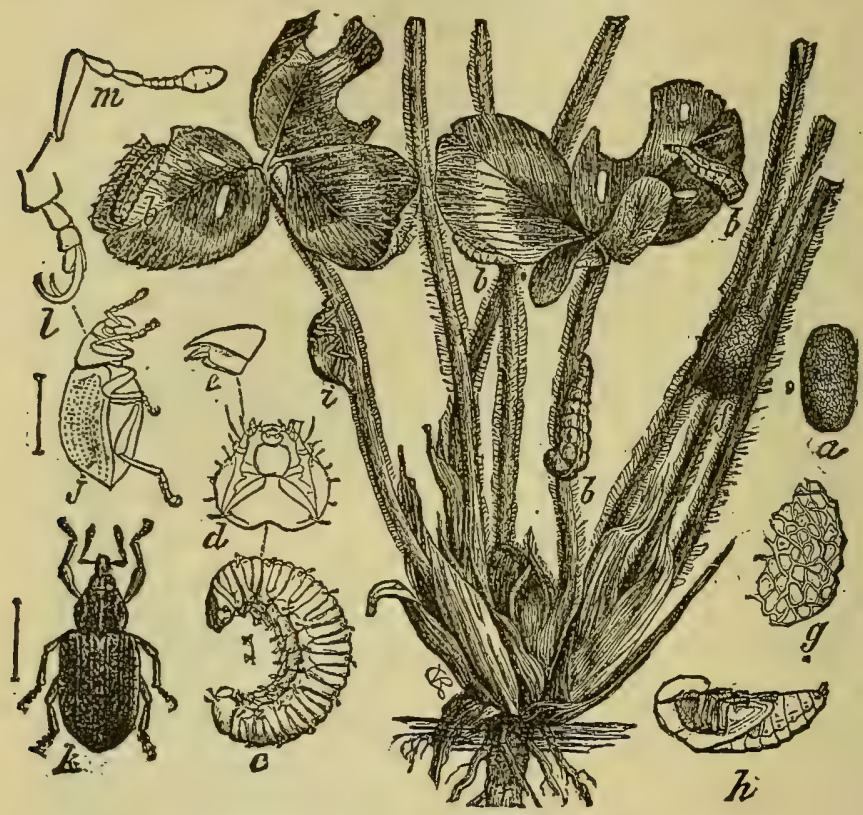

Fig. 126. Clover Leaf-beetle: $b, b, b, b$, larvæ feeding; $\boldsymbol{f}$, cocoon; $i$, beetleall natural size; $a$, egg; $c$, young larva; $g$, meshes of cocoon ; $h$, pupa; $k, j$, beetle, back and side views-magnified.

clover leaves at night, remaining concealed among the rubbish on the soil surface during the day. The female beetles deposit their eggs in irregular clusters in the hollow leaf for flower stems or between the 
leaf-bracts at the base of the plant. The eggs are very small, oval, smooth, and yellowish-green. Each female is capable of depositing 200 to 300 eggs. In about ten days the larvæ hatch and begin feeding on the leaves. They are legless little grubs of the form shown at $c$. They continue feeding and growing $(b, b, b)$ for seven or eight weeks, increasing much in size and moulting three times during the period. The larvæ, like the beetles, are mostly nocturnal in their habits, and ordinarily remain concealed during the day. The full grown larvæ form pale yellow cocoons, consisting of a coarse network of silk $(f, g)$ in the soil, just beneath the surface. They pupate $(h)$ within these cocoons, and a month later emerge as beetles. There is apparently but one brood each season, although it is possible that there may sometimes be two. During the early summer months (May and June) it is mostly in its immature stages. It ordinarily hibernates as an adult, but may also occasionally pass, the winter in the other stages of its existence.

Remedies.-The only remedy yet suggested is that of plowing under infested fields during May or June, thus destroying the immature stages.

\section{INJURING THE HEAD.}

\section{The Clover Seed-midge.}

Cecidomyia leguminicola.

The Clover Seed-midge is a small, orange-colored maggot that develops in the clover heads at the 
expense of the young seeds. It hatches from eggs laid

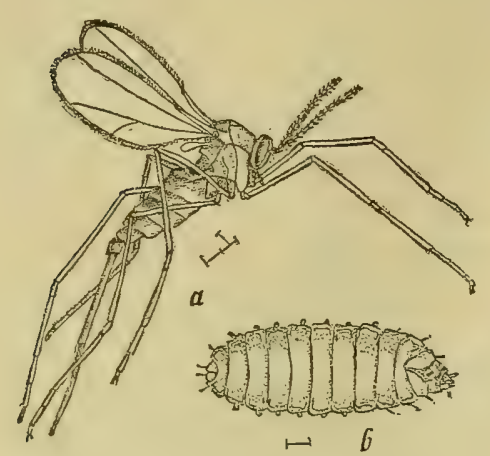
by a very small, twowinged fly (Fig. 127, a), similar to the Hessian Fly in appearance. The female is provided with a long ovipositor with which she pushes her eggs in among the young flowers. When the

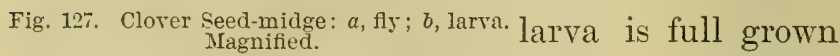
(b) it wriggles its way out of the head and falls to the ground, where at or just beneath the soil surface, it forms a slight cocoon, within which it changes to the pupa state. About ten days later the flies emerge to lay eggs for another brood. In the Northern States there are two broods each season, while at the South there are at least three, and possibly more. Clover fields infested by this insect are at once distinguished by the unnatural condition of the heads at time of blossoming: instead of being red with bloom, the heads are green and dwarfed on account of the undeveloped florets.

Remedies.-The best preventive of the injuries of this insect yet suggested is that of mowing the field about the middle of May (in the latitude of central Ohio) when the green heads are just forming, and leaving the partial crop thus cut on the ground 
as a mulch and fertilizer. A new crop of blossoms is then produced, which comes between the regular crops, and also between the two broods of the Midge. This method has been tried for several years by some of the best farmers of Ohio, with excellent results. The other remedies ordinarily recommended are early cutting of the first crop-about ten days earlier than usual-and pasturing the fields in spring. But there are serious objections to both these methods.

\section{INJURING THE STEM.}

\section{The Clover Stem-borer.}

Languria mozardi.

This insect has been frequently discussed in entomological literature as an enemy to clover, but no

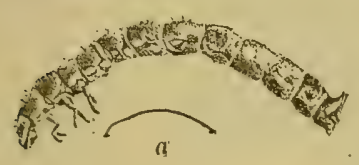

record has yet been made showing that it ever seriously injures this crop. Until lately it was supposed to develop exclusively in

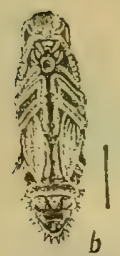

Fig. 129. Clovér Stem-bore $; a$, lar va; $b$, pupa ; $c$, beetle. Magnified.

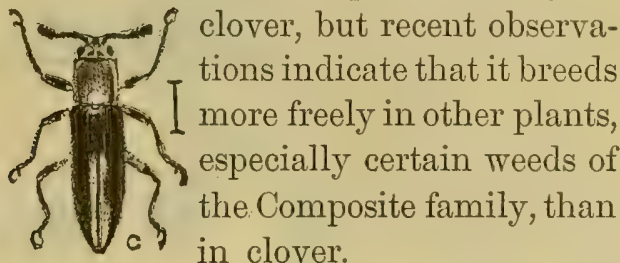

The three later stages of this Clover Stem-borer are represented, magnified, at Fig. 129. The adult insect, shown at $c$, is a small, 
elongate beetle, about one-fourth of an inch long, with the thorax yellowish red, and the wing-covers shining bluish-black. The larva, represented at $a$, is a slender, cylindrical creature, with three pairs of jointed legs on its under surface near the head, and a pair of pro-legs at the posterior extremity. The pupa is well shown at $b$ of the same figure. It is usually of a yellowish color.

The eggs of this insect are evidently deposited in a great variety of plants, in the stems of which the larræ develop, feeding upon the pith of the stalk. So long as there is a plentiful supply of wild plants, it is doubtful if it becomes of economic importance.

\section{INJURING THE HAY.}

\section{The Clover Hay-worm.}

Asopia costatis.

Clover hay that has been standing in the mow or stack for sometime, is often infested by numerous small brown worms which web the dried stems and leaves together and feed upon them. This is the insect named above, and its various stages a r e represented,

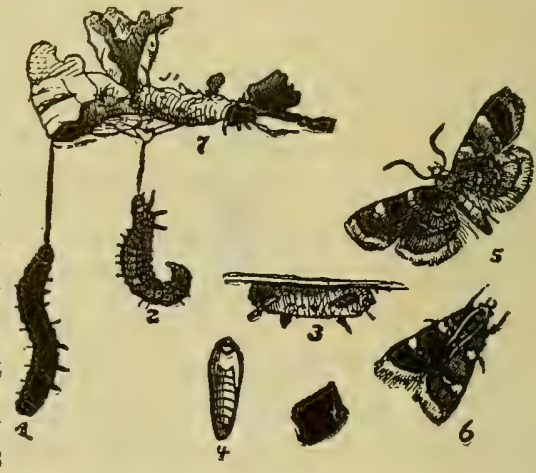

Fig. 130. Clover Hay-worm : 1, 2, larva ; 3, cocoon; 4, pupa ; 5, 6, moth. 
natural size, at Fig. 130. The adult is a very pretty little purple and golden moth $(5,6)$ which deposits eggs upon such clover hay as it has access to. The eggs soon hatch into small brown worms that become full-grown $(1,2)$ in a few weeks. They then spin silken cocoons (3) within which they change to chrysalis (4), to emerge soon after as adult moths. There are two or more broods each season.

Remedies.-It will readily be seen that these insects are more likely to prove troublesome when old hay is left over from season to season for them to breed in. Consequently hay mows should be thoroughly cleaned out each summer, and new stacks should not be put on old foundations until all of the leavings of the previous season are removed. Hay which is thickly infested by the worms should be burned.

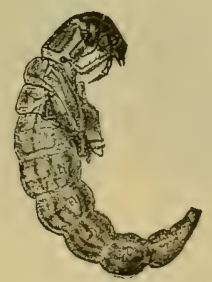




\section{INSECTS AFFECTING GRASS.}

\section{INJURING THE ROOTS.}

\section{The White Grub.}

Lachnosterna fusca.

This notorious pest is the young or larva of the common May Beetle or June Bug. Its life-history may be briefly summarized as follows: The brown beetles, shown at 3 and 4, Fig. 131, appear during

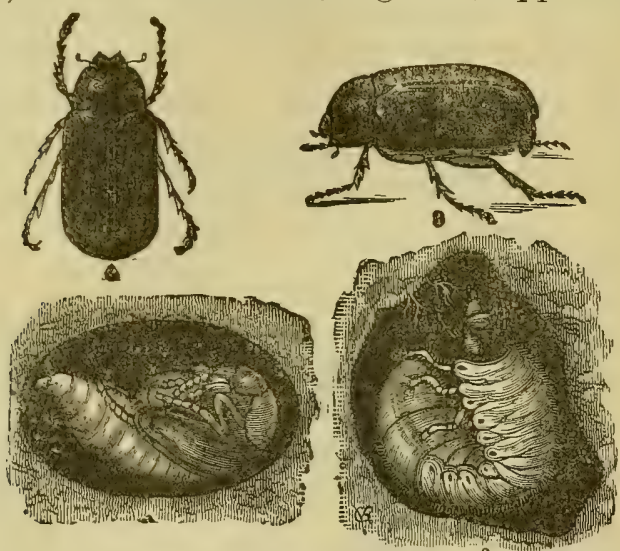

Fig. 131. May Beetle: 1 pupa: 2 , larva: 3 and 4, adult.

May and June, and feed at night upon the foliage of various fruit and shade trees. They deposit small, whitish eggs among the roots of grass. These eggs hatch into small, brown-headed grubs, that feed upon the roots about them. They continue feeding for two seasons, when they are full grown and 
resemble 2, Fig. 131. They then form an oval cell in the soil and change to the pupa state, and soon after transform into beetles. The change to the pupa and beetle stutes generally occurs in fall, the beetles remaining in the ground until the following spring, so that they are often turned up during late fall or early spring plowing.

Remedies.-This insect is one of the most diffcult pests to fight of its class. It breeds especially in grass lands, and often ruins pastures and meadows, while crops planted on sod land are very frequently destroyed. There is much evidence to prove that with high farming and short rotations its injuries may largely be prevented. The parent beetles may be destroyed by spraying the trees on which they feed with London purple or Paris green. It will often pay, when land infested by these grubs is to be planted to strawberries or other crops which they are liable to injure, to have boys follow the plow and collect the grubs as they appear in the furrow. In this way a large amount of damage can frequently be prevented at very slight expense. The grubs in infested meadows may be destroyed by turning swine in the field.

\section{The Meadow Maggot.}

Tipula bicarnea.

Meadows are sometimes injured by large, darkcolored, legless grubs of the form represented at Fig. 132 , a, which feed upon the roots just beneath the 
surface. These are the larvæ of Crane Flies, the large two-winged insect represented natural size at $c$ of the figure. The adults appear in spring, often in great numbers, and deposit numerous eggs in grass lands. In a short time these eggs hatch into

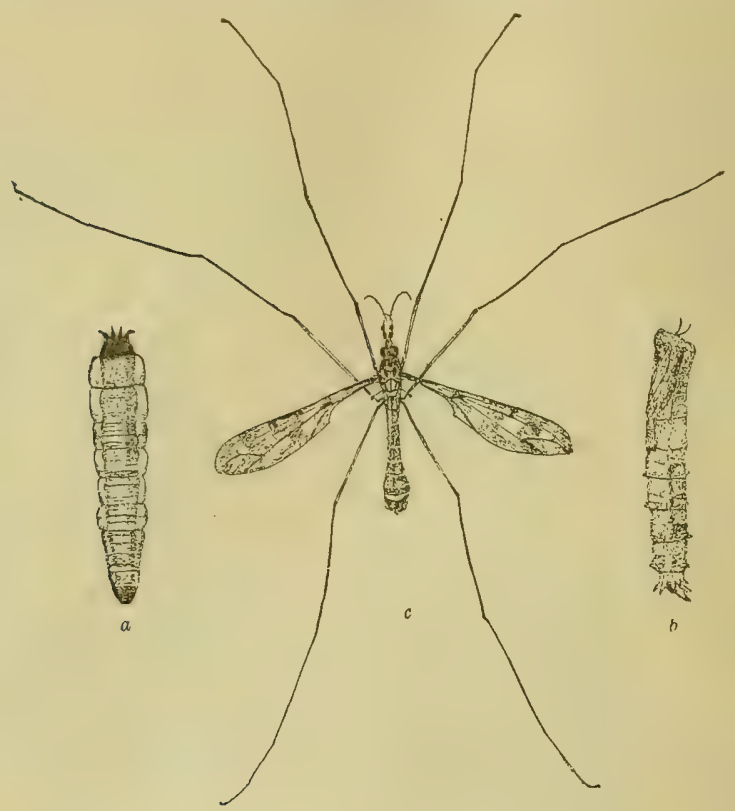

Fig. 132. Crane Fly: $a$, larra; $b$, pupa ; $c$, adult.

small, blackish grubs that feed upon the roots of grasses and other plants. They continue feeding for some time before becoming full-grown-their food including much decaying regetation as well as the living roots, - when they are about an inch long, and of a:dirty grayish black color. They now change to 
pupre, one of which is represented at $b$, and about a fortnight later the flies emerge with their long legs and slender wings. The larvæ are commonly called Leather Jackets or Meadow Maggots. In England the crane flies are called daddy-long-legs, although in this country this name is usually applied to the harvest-spiders, a common species of which is represented at Plate VI (p. 208). There are a great many species of these crane flies in America, and the later stages of one of the largest of them are represented in the accompanying figure.

Remedies.-In America these insects rarely become sufficiently injurious to require remedial treatment. When they do the most successful plan yet tried is that of driving a flock of sheep or herd of swine over the field to kill the larvæ by their tramping.

\section{INJURING THE LEAVES.}

\section{The Army Worm.}

Leucania unipuncta.

This is one of the most noted insect enemies of American agriculture. It occasionally does great damage to a variety of cereal and forage crops, although during recent years its irruptions appear to be growing less frequent. The worm itself is closely related to the cut-worms, to which it is similar in life-history and habits. It hatches from eggs laid by 
a handsome brown moth (Fig. 133, a) between the sheaths of grass blades. The young larvæ hatch in a week or ten days, and are at first green, but later become ornamented with longitudinal stripes of yellow, gray, and black, (b). The larva feeds upon the leaves of grass, wheat, oats, rye, etc., and becomes full grown in about a Fig. 133. Army Worm: $a$, moth; $b$, larva. month from the time of hatching. Ordinarily it remains concealed about the bases of grass or grain, feeding there unnoticed, but occasionally the larvæ become so numerous that they exhaust their food supplies, and then they are forced to seek other feeding grounds. At such times the "armies" appear, and moving in solid masses sweep all grasses and cereals before them. The full-grown larvæ enter the ground and pupate in earthen cells, emerging a fortnight later as moths. In southern latitudes there are two or three broods each season, while at the North there are one or two. The insect hibernates both as a moth and larva, although the latter doubtless predominates.

The Army Worm has a great many enemies with 
which to contend. It is preyed upon by birds, as well as by predaceous and parasitic insects, and is subject to the attacks of certain bacterial diseases that often sweep the larve off by millions. - These various natural enemies are the chief means of keeping the pest in check.

Remedies.-The burning of pastures and meadows during fall, winter, or spring, especially the latter, is very often recommended as a remedy for the Army Worm, and large numbers of the larvæ may thus be destroyed. The migration of the worms from field to field may be prevented by plowing deep furrows with the perpendicular sides away from the worms, or by setting fence boards on edge, leaning a little toward the worms, and smearing the upper edge with coal tar. With the improved appliances for distributing Paris green and London purple now in use, these poisons will no doubt be more largely used in suppressing future outbreaks of these worms than in the past. It is quite probable also that we may before long be able to fight them by means of the germs of the contagious diseases to which they are subject.

\section{Grasshoppers.}

Acrididx.

The family of locusts or short-horned grasshoppers - commonly called simply grasshoppers-contains many species which are more or less injurious in pastures and meadows. The hind legs of these insects are long and strong, enabling them to make the 
leaps or hops which has given them their common name. The largest species of this family inhabiting the United States is the Bird Grasshopper or American Locust (Acridium americanum) represented natural size at Fig. 134. At a little distance, when flying, this handsome insect might easily be mistaken

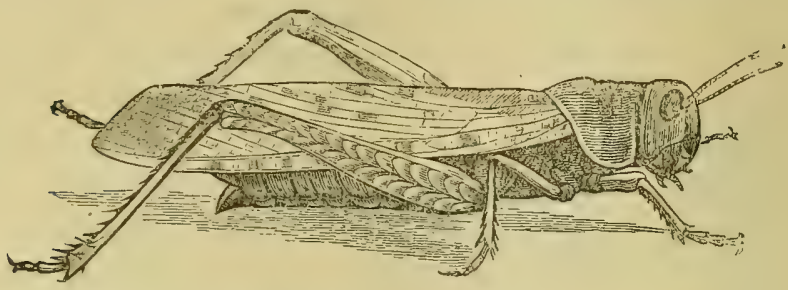

Fig. 134. Bird Grasshopper or American Locust.

for a small bird. It inhabits the Southern States, but occurs rather commonly as far north as the fortieth degree of latitude.

The Rocky Mountain Locust or Western Grasshopper (Melanoplus spretus) is the most destructive American insect of this family. Its stages of growth are shown at Fig. 135. The eggs are laid during the late summer or early autumn months, in masses of twenty or thirty each, in the soil just below the surface. They remain over winter in this condition, hatching in spring into wingless little hoppers, as shown at $a, a$. They gradually increase in size, and cast their skins after a short time, when they resemble $b$. They acquire wing-pads in the stage immediately preceding that of the adult, as shown at $c$, and 
finally become full-fledged $(d)$. They are active

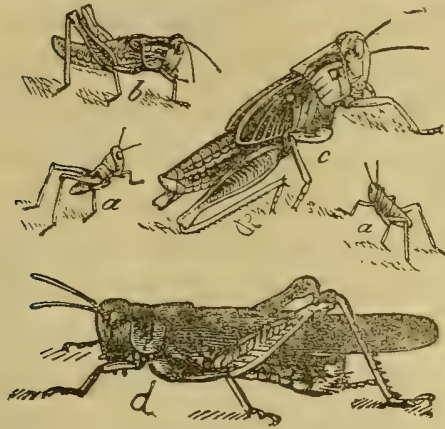

Fig. 135. Rocky Mountain Locust: $a, b$, young nymphs; $c$, fully dereloped nymph or pupa; $d$, adult. during their entire existence. The native home of this species is in the high and dry table lands of the Rocky Mountain regions, where it breeds year after year. Occasionally it becomes so abundant in these regions that the food supply is exhausted, and it is compelled to seek by flight green pastures. It is at such times that these insects migrate in vast swarms to the fertile fields of the Mississippi Valley, destroying every vestige of greemness in their path. Fortunately, however, they are unable to breed permanently at these lower levels, and although eggs are deposited by these invading hordes, the young hoppers hatched from them seldom attain a healthy development.

The commonest grasshopper in the Northern States is called the Red-legged Locust (Melanoplus femur-rubrum): It is closely allied and very similar to the Rocky Mountain Locust. It frequently becomes seriously destructive in restricted localities, but never does the ride-spread damage of its Western congener. The life-history of this species has been summarized by Professor S. A. Forbes as follors: "These locusts are single-brooded; they hibernate in the egg, hatching ir midsummer; pass 
through five successive monlts, gaining their full size, and with this their wings, in August, and commence to lay eggs in September. The females deposit these in the earth, boring cylindrical holes for the purpose with the abdomen, and laying the eggs in a symmetrical mass within the burrow thus formed. With the egg mass is extruded a quantity of mucus, which soon hardens and forms a sort of case or matrix, in which the eggs are imbedded. The upper part of the hole is also filled with this mucus. The female is commonly busied from two to four or five hours in the deposit of a single egg mass, and lays, ordinarily, from two to four such masses in different holes, upon different days, commencing the process of oviposition, as a rule, about a month after she has acquired her wings. After this process is completed the exhausted females soon perish. They select by preference, for oviposition, hard and dry ground, roadsides and pastures being especially favorite localities. Meadows and pastures are commonly resorted to by the mature females, especially the latter, as the eggs seem not to be laid ordinarily on ground covered by luxuriant vegetation. I have never known them deposited in cultivated earth.

"The food habits of these locusts are extremely simple, and consist in eating nearly everything that comes in their way. They are quiet at night, and indeed, as they mature, they select elevated positions as roosts, climbing to the tops of stems of grass in meadows, to the tassels of the stalks in corn fields, 
and even deserting fields of low herbage if they can find more elevated roosting points near by. When very abundant, and when the weather continues dry, they occasionally swarm like the Rocky Mountain Locust, but rarely flying continuously to any great distance, or indeed taking any definite course."

Fortunately there are a considerabie number of species of animals that depend, to a greater or less extent, upon grasshoppers for subsistence. Some of these are predaceous, others parasitic, but all combine in keeping the pests in check. Prominent among those efficient in this work are the species that live upon or within the eggs of the locusts, as the latter exist in that state for the longest period of their lives, and are also then the most helpless and susceptible to injury. The common blister beetles (Epicauta) live, so far as known, in their larval state, exclusively upon the eggs of locusts, and are thus of immense benefit to man. Small red mites, which are frequently seen attached to the bodies of the mature locusts, are also of benefit, in that while young they suck the life-juices of the locusts, and, later, puncture their eggs and extract the contents. The larvæ of the common black ground beetles (Carabidæ) which are, to a great extent, carnivorous, also feed upon the eggs, and, as they are everywhere abundant, contribute not a little to lessening their numbers. Certain species of two-winged flies (Diptera) are also known to be parasitic upon the eggs as well as the adults. 
Remedies.-The time when grasshoppers can most successfully be fought is when they are either in the egg or young larval states. Shallow plowing and harrowing, during autumn, of fields where they are deposited will break up many of the egg pods, exposing them to enemies and the weather. The methods by which young locusts may be destroyed have been classified by the United States Entomological Commission as follows: (1), burning; (2), crushing; (3), trapping; ( 4 ), catching; (5), use of destructive agents. By the first method old hay or straw is scattered "over and around the field in heals and windrows, into which the locusts for some time after they hatch may be driven and burned." When the weather is cold and damp the locusts will seek the shelter of the hay or straw, and may easily be burned before escaping. This method is well adapted to upland pastures, where the eggs are usually deposited in the greatest numbers.

For the successful application of the second method mentioned above, it is necessary that the surface of the fields on which it is applied should be smooth and hard. Here, again, the upland pastures present unusually favorable opportunities for successful work. Dr. Riley states that "Where the surface of the ground presents this character, heavy rolling can be successfully employed, especially in the mornings and evenings of the first eight or ten days after the newly hatched young have made their appearance, as they are generally sluggish during these times, and huddle together until after sunrise." 
The third head given above, that of trapping, includes ditching, trenching, and the use of pans covered with coal oil, or coal tar. In the first two processes, ditches or trenches are dug in favorable situations, into which the young insects are driven. Probably the use of pans covered with coal oil will be as simple and advisable a method, unless we except that of rolling, as can be employed in most infested districts. A small pan which is well adapted for the purpose is described as follows: "A good and cheap pan is made of ordinary sheet iron eight feet long, eleven inches wide at the bottom, and turned up a foot high at the back and an inch high at the front. A runner at each end, extending some distance behind, and a cord extending to each front corner, completes the pan, at a cost of about $\$ 1.50 . "$ The upper surface of the bottom is wet with kerosene, and the pans are pulled rapidly through the field by boys who take hold of the ropes.

The use of destructive agents; such as London purple, Paris green, and the like, has not been attended with any very great success when applied on a large scale. But for limited areas, doubtless a great many of the locusts may thus be easily destroyed. A mixture which has been successfully employed, consists of "arsenic, sugar, bran, and water, the proportions being one part, by weight, of arsenic, one of sugar, and five of bran, to which is added a certain quantity of water. The arsenic and bran are first mixed together, then the sugar is 
dissolved in water and added to the bran and arsenic, after which a sufficient quantity of water is added to thoroughly wet the mixture. About a teaspoonful of this mixture is thrown upon the ground at the base of each tree or vine (in gardens and orchards) and left to do its work. The poison works slowly, seldom killing its victim within eight or ten hours after it has been eaten."

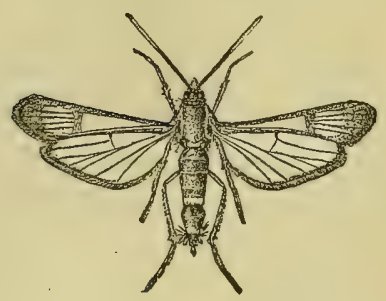




\title{
PART VI.
}

INSECT PESTS

\author{
OF
}

DOMESTIC ANIMALS

AND THE

HOUSEHOLD. 

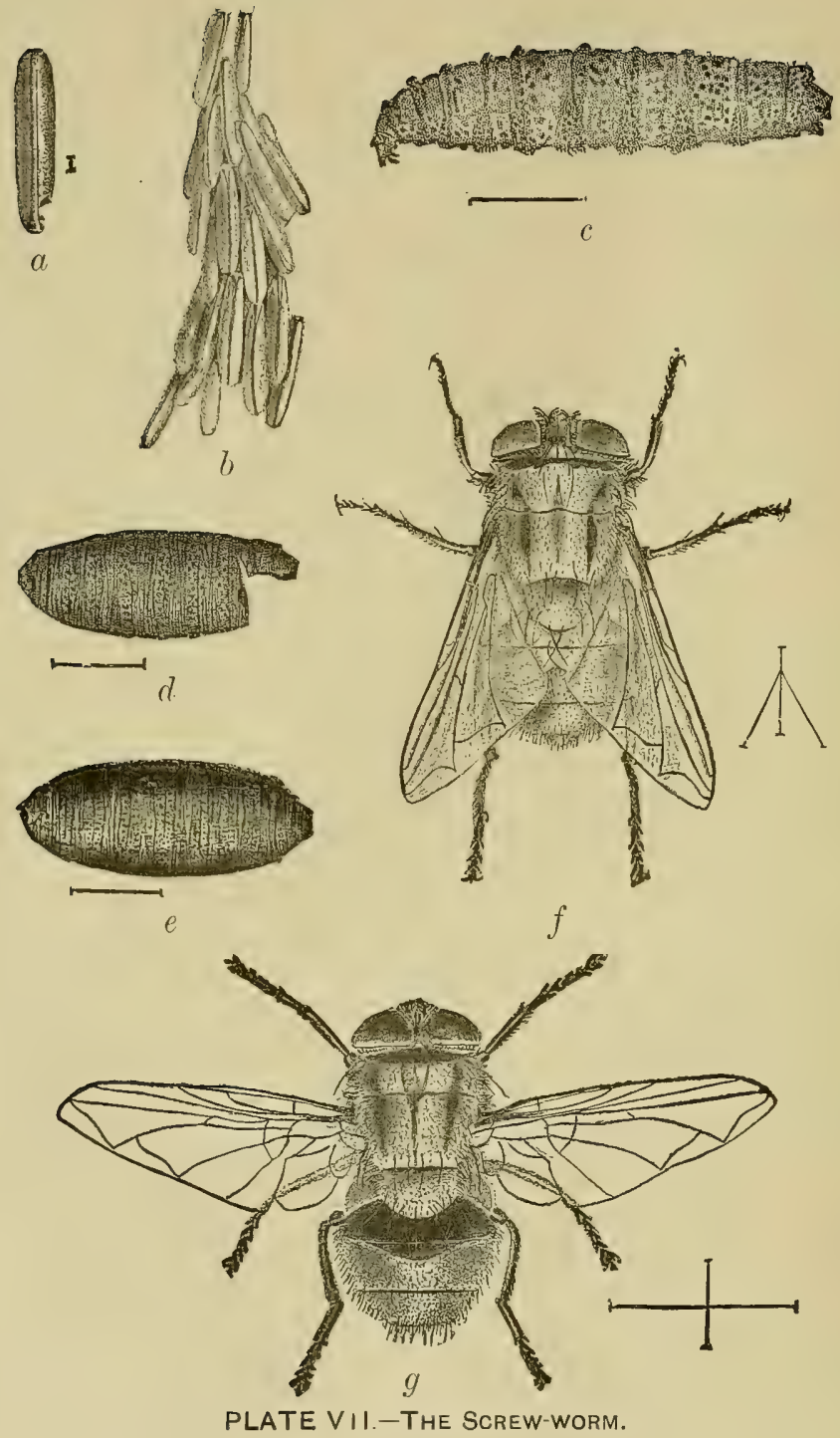


\section{INSECTS AFFECTING DOMESTIC ANIMALS.}

\section{The Screw Worm.}

\section{Compsomyia macellaria.}

The Screw Worm, so far as its injuries are concerned, is a southern insect. Until recently little or no damage from it had been reported outside of Texas, but lately it has been injurious in Louisiana, Mississippi, and other Southern States. The fly, however, occurs throughout America 'from Canada to Patagonia,' probably breeding in northern latitudes in decaying animal and vegetable matter. Although in the South cattle are specially liable to the attacks of this insect, it is by no means confined to them, for horses, mules, hogs, sheep, dogs, and in some recorded cases even men, suffer on account of it.

"In all animals alike," according to Dr. M. Francis, who has studied this insect carefully, "the eggs, after being laid by the fly, hatch into larvæ or so-called. 'worms.' The exact length of time this requires seems to vary with circumstances. My present opinion is that if the eggs are laid in a moist place and on a warm day, it requires less than one hour; whereas, if laid in a dry place they seem to dry up and lose their vitality. The young larvæ, when first hatched, are small and easily overlooked. If they are hatched on the surface in a drop of blood from a ruptured tick, for instance, they attempt to perforate the skin, and if hatched in wounds they at once 
become buried out of sight. They seem to attach themselves by their heads, and burrow their way under the skin, completely devouring the soft flesh. Occasionally a few are seen moving from one place to another, but usually they remain fixed at one point. The worms grow steadily in size, and the hole in the flesh becomes larger every day. Sometimes the worm makes tunnels, but not to any depth; they usually stay on the surface. They evidently produce considerable irritation, for the part is always swollen and constantly bleeding. This swollen, gaping ampearance of the wounds, together with the constant discharge of blood, are characteristic of the presence of worms. It seems to require about a week for the worms to become fully grown. At that time they are about five-eighths to six-eighths of an inch long. They then leave the sore and go into the ground, where they pass the pupa state, and hatch out as flies in from nine to twelve days."

In the accompanying plate (VII) the eggs are shown at $a$ and $b$, the first representing a single egg, greatly enlarged, and the second a bunch of eggs, also enlarged; the larva is represented at $c$, and the puparium at $d$ and $e$, the former showing the mode of exit of the fly, which is represented at $f$ and $g$.

The egg of this insect is $\frac{1}{2} \cdot 5$ inch long, whitish, and cylindrical, with a longitudinal ridge on one side. The full-grown larva is $\frac{1}{5}$ inch long by $\frac{1}{6}$ inch in diameter. It is a whitish, footless grub, with transverse rows of stiff, black bristles at each articulation. 
The puparium is brown, and $\frac{2}{5}$ inch long. The imago is described as follows: Length, $\frac{2}{5}$ inch; wing expanse, $\frac{4}{5}$ inch; color, metallic bluish-green, with golden reflections; thorax, with three black, longitudinal stripes; head, except central portion of eyes, yellow; legs, black; wing veins, black; wings, transparent, except near base, where they are slightly clouded. Entire body furnished with long, black, spinose hairs. Proboscis of medium length, with dilated tip.

Remedies.-According to Dr. Francis, the treatment usually employed consists simply of killing the larvæ with cresylic ointment, calomel, chloroform, or carbolic acid. Inasmuch as the insect is able to develop freely in decaying animal and vegetable matter it is important, as a preventive measure, that all refuse be promptly buried or burned.

\section{The 0x Warble Fly.}

\section{Oestrus bovis.}

During the spring and early summer one may often find along the middle of the backs of cattle, just beneath the skin, a hard lump, usually liaring in the center an opening, which sometimes is more or less of a running sore. These are the "warbles," and the lump is caused by the presence of a whitish or grayish maggot of the form represented at a, Fig. 136. Early in summer these maggots wriggle out of the warbles, tail foremost, through the opening represented at $d$, and fall to the ground, where, under such protection as may be at hand, they shorten 
for pupation as shown at $d$, and soon change to the pupa or chrysalis state, represented at $e$. About a month later they emerge as adult flies, one of which is represented, natural size, at $a$. These flies pair, and the females deposit eggs on the backs of cattle. The eggs hatch into grubs that work their way into the skin, where they form the warble cells. Their mouth parts irritate the flesh, causing an ulceration,

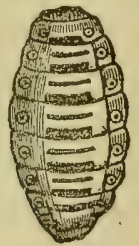

a

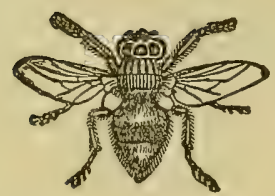

$c$

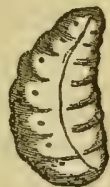

$b$

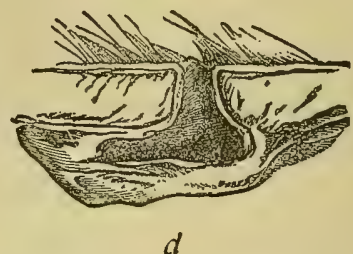

Fig. 136. Ox Warble Fly: $a$, larva; $b$, pupa; $c$, fly; $d$, section of warble. which not only is distressing to the animal, but injures the hide and beef, and, in the case of dairy animals, lessens the quantity of milk produced.

The beef beneath these warbles has a peculiar, diseased, sickening appearance, and is commonly called "licked beef." Such beef always commands a lower price than that which is unaffected.

Remedies.-Every warble maggot destroyed in spring before it escapes to the ground to pupate, 
means that one less fly will be present to lay eggs for the coming brood. This should be carefully borne in mind, for from it the conclusion is obvious that if all the maggots present in the backs of cattle of a given neighborhood are killed, the egg-laying brood of flies will be exterminated, and there will be no injury the next season. There is perhaps no other important injurious insect whose numbers can be so readily controlled; and the experience of English farmers shows that by concerted action and continuation of the treatment the amount of warble attack may be very rapidly. lessened.

Perhaps the simplest remedy to use during spring and early summer is to squeeze the maggots out of the warbles. When they are nearly full grown this can be done with little trouble; and when smaller the opening can be enlarged with a pen knife so as to let them out. A pair of medium sized forceps is often helpful in removing them.

Another simple remedy is to apply to the opening a little oil or grease, which closes the breathing pores of the maggot, thus causing it to die. Kerosene applied to the warbles either in autumn, winter or spring also destroys them, as does indeed the application of almost any oily or fatty substance. Train oil or fish oil is especially commended in England. Dr. C. V. Riley says that smearing the animals" backs with this substance " is the simplest and easiest method of destroying the warbles, which it does by closing the breathing pores on the posterior end 
of the body. The destruction of the larvæ in this way may be effected by one or two applications in autumn, and is the most satisfactory method of controlling the pest."

It is also frequently recommended to smear the backs of the cattle during summer with fish oil, kerosene emulsion, or some similar substance, to prevent the flies from depositing eggs, but this is a much less practical method than that of destroying the maggots, because the flies are present nearly all summer, making it necessary that the application be frequently renewed.

\section{Cattle Lice.}

There are three species of lice infesting cattle. Two of these belong to the group of sucking lice and the third is one of the biting lice. They are called (1) the Short-nosed Ox-louse; (2) the Long-nosed Ox-louse; and (3) the Biting Ox-louse.

The Short-nosed Ox-louse (Hæmatopinus euryster-

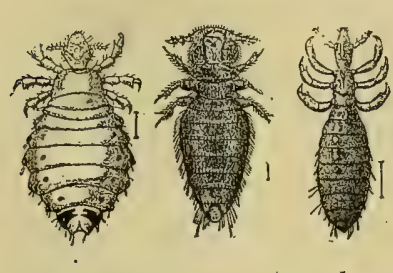

Fig. 137. Lice: $a, b$, sucking ox-lice; $c$, biting horselouse. Magnified. nus) is represented considerably magnified at. Fig. 137, a. Full grown females of this species are one-sixth of an inch long, and the males are somewhat smaller. The beak or rostrum is provided with little hooks by which it may be firmly attached to the skin, and within these hooks there is a slender sucking tube having a piercing extremity which the 
insect pushes through the skin of its host, and sucks the blood. The eggs are glued to the hairs of the cattle, and the young lice do not differ essentially in appearance from the adults, except, of course, in size. These insects generally infest the neck and shoulders of cattle.

The Long-nosed Ox-louse (Hrmatopinus vituli) is represented magnified at Fig. 137, b. As will be seen, it differs materially in appearance from the other species, being at once distinguished by its longer and more slender body. It is about one-eighth of an inch long, and obtains its food by suction.

An idea of the form of the Biting Ox-louse (Trichodectes scalaris) may be obtained from Fig. 137, c, which represents a closely related insect infesting horses. This species differs also in color from the sucking cattle lice, being of a reddish hue. Its eggs are glued to the hairs of the cattle. It is very abundant in all parts of the world where domestic cattle are found.

Remedies.-The best method of destroying lice on cattle and other domestic animals is to apply a thoroughly prepared emulsion of kerosene and soap, made as directed in the Introduction (page 20). If this is well made it can be applied to cattle and horses, hogs and sheep, with no danger of injury to them, while it will destroy all the lice with which it comes in contact. Professor C. P. Gillette, who first gave this method a thorough trial, recommends applying it with a force pump and spray nozzle, rubbing 
it in thoroughly with the finger tips at the same time. It kills the lice and leaves the hair of the animal in good condition. The lice may also be destroyed by treating with a strong tobacco decoction - a pound of tobacco being boiled in two gallons of water-or a wash of carbolic acid soap. But the first named remedy is best.

\section{The Horn Fly.}

Haematobia serrata.

This is an imported insect which has lately attracted much attention in the Eastern States. It is called the Horn Fly because of the peculiar habit the flies have of gathering in clusters upon the base

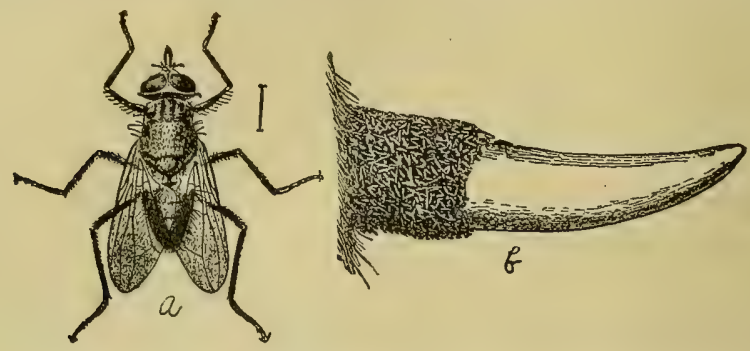

Fig. 138: $a$, Horn Fly, magnified; $b$, cow-horn with band of resting flies, reduced.

of the horn, as represented at Fig. 138, $b$. They light here to avoid being disturbed by the heads or tails of the cattle, but do not pierce the horn or do any serious injury to it. On the body, however, where they light when feeding, they insert their beaks into the skin, injecting at the same time a little poisonous secretion which causes irritation and inflammation, and a flow of blood to the spot. This 
blood is then sucked into the stomach of the fly. Cows thus attacked become restless and irritable, and, if the flies are very numerous, they lose flesh and givie less milk.

The eggs of the Horn Fly are deposited in freshly dropped cow-dung in which the larvæ develop, and pupate in the soil beneath. There are four or five broods each season. During hot weather the transformations of the insect-from egg to imago-may be completed within two weeks.

Remedies.-Two classes of preventives may be used against this insect. The injuries to cattle may be prevented by applying to their bodies, by means of a sponge, fish oil to which has been added a little carbolic acid. Only the tips of the hairs need be wet, and the application should be repeated every four or five days. This will keep the flies off the animals, though it does not kill them. They may be killed, however, by the use of tobacco powder, dusted on the cattle, especially on the back, tail, neck, and base of the horns. Professor J. B. Smith recommends the use of the carbolated fish oil on the belly, udder, and other parts of the body where the tobacco cannot well be applied, and the application of the powder to the other parts. The larvæ also may be destroyed by spreading out the cow droppings each morning, so that they will dry up, and thus prevent the development of the eggs or maggots, or by mixing plaster with the manure in the stable or field. 


\section{Lice Infesting Horses.}

Three species of lice infest the horse. The first is the Sucking Horse-louse (Hæmatopinus asini) which is represented, considerably magnified, at Fig. 139, $\alpha$. It is somewhat similar to the Sucking Ox-louse, to which it is closely related, but is easily distinguished from that species by the shape of the head. It is the rarest of the three species infesting the horse, the next commonest one being the Rarer Biting Horse-louse (Trichodectes pilosus) represented at Fig. 139, $b$, which, as its name Fig. 139: $a$, Sucking Horseindicates, is less abundant than

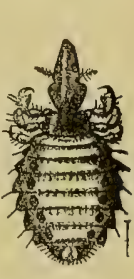

$a$

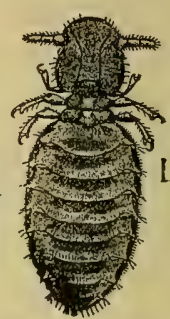

$b$ louse. Magnified. the third species-the Common Biting Horse-louse (Trichodectes parumpilosus), which is shown at Fig. $137, c$. This last is the most abundant and annoying, and is especially liable to infest colts or horses that have been in pasture for some time. It occurs mostly about the head, mane, and tail ; and is generally thickest in spring. The front part of the body is brownish, and the abdomen is yellowish-white, with eight transverse dark bands upon the back.

Remedies.-The remarks concerning remedies. for cattle lice are equally applicable to these species. 


\section{INSECT PESTS OF THE HOUSEHOLD.}

\section{Cockroaches.}

Cockroaches are among the most omnivorous as well as omnipresent of the insect pests of the household. Their flattened bodies especially fit them to dwell in cracks and crevices, in the walls of houses in cities, and beneath the loose bark of fallen trees in the woods. Here they find congenial retreats and flourish abundantly. They take a great variety of food. In dwellings they destroy provisions of every kind, although, as a partial recompense, perhaps, they are also said to prey upon Bed Bugs.

As has been so often the case with our injurious insects, we are indebted to Europe for the cockroaches that are most obnoxious. The American Cockroach (Periplaneta americana) occurs commonly in the fields and woods, and occasionally is found in houses. But the Oriental Cockroach (Periplaneta orientalis) and the Croton Bug or German Cockroach (Phyllodromia germanica) -both imported speciesprefer the city dwelling, where, around the steam and water pipes of the kitchen, laundry or bathroom, they can run about undisturbed. They are nocturnal in their habits, remaining concealed during the day, and sallying forth in search of food during the night.

The life-history of the Croton Bug has been admirably portrayed by Dr. C. V. Riley at Fig. 140. The 
eggs are laid in a pod or egg-case $(f, g)$ from which

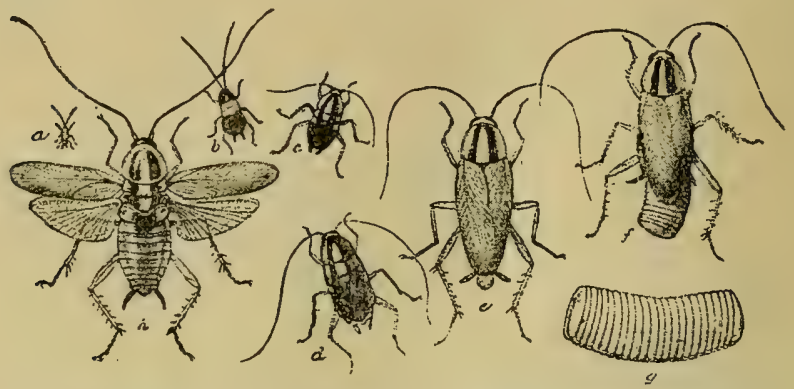

Fig. 140. Croton Bug: $a$, first stage; $b$, second stage; $c$, third stage; $d$, fourth stage ; $e$, adult: $f$, adult female with egg-case; $g$, egg-case -enlarged : $h$, adult with wings spread-all natural size except $g$.

the young roaches hatch. They pass through various moults as represented at $a, b, c, d$, and do not acquire wings until full-grown $(e, f, h)$, when they are nearly two-thirds of an inch long. The other roaches develop in a similar way.

Remedies.-The best remedy for these pests is a good quality of insect powder, such as Buhach. In recommending this, Dr. Riley says:

"Just before nightfall go into the infested rooms and puff it into all crevices, under base-boards, into drawers and cracks of old furniture-in fact wherever there is a crack-and in the morning the floor will be covered with dead and dying or demoralized and paralyzed roaches, which may easily be swept up or otherwise collected and burned. With cleanliness and persistency in these methods the pest may be substantially driven out of a house, and should never be allowed to get full possession by immigrants from without." 


\section{The Buffalo Carpet Beetle.}

\section{Anthrenus scrophularix.}

The Buffalo Carpet Beetle is supposed to have been introduced into America from Europe about 1876, since when it has done great damage and spread over a large portion of the eastern and central United States. The adult beetle (Fig. 141, d) is about a

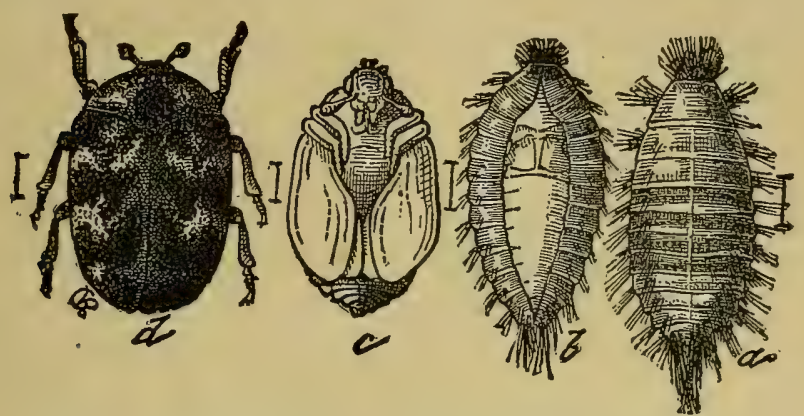

Fig. 141. Carpet Beetle: $a$, larva, back view; $b$, larva, view of under side; $c$, pupa; $d$, beetle. Magnified.

quarter of an inch long, black, with white spots, as shown in the figure, and has a red stripe along the middle of the back. Eggs are laid by these beetles, probably upon carpets themselves, and soon hatch into larvæ that feed upon the carpets. It is in this larval stage that the damage is done. The larvæ cast their skins occasionally as they develop, and the time required for them to become full grown varies according to the temperature and food-supply. When full grown they are peculiar, hairy creatures of the form represented at $a$ and $b$ of the accompanying 
figure. They now hide in a crack or crevice, and change to pupæ $(c)$ inside the hairy skin. In a short time they again change to the beetle state, the beetles emerging throughout the fall, winter, and spring. There is probably, in ordinary cases, but one generation a year, at least in the Northern States.

Remedies.-In Europe this insect does very little damage, because rugs are used instead of carpets. Rugs are taken and shaken so often that the insects have no opportunity to multiply. The use of rugs should therefore be encouraged in regions where the insect is troublesome.

Perhaps the most practical way of really destroying these insects in carpets without taking them up, is to lay two or three thicknesses of wet cloths on the carpet, and iron with hot flat irons. Steam will thus be generated, which will permeate the carpet and kill the insects. The pests may readily be killed in furniture or garments by the use of benzine or gasoline, applied as a spray by some sort of atomizer, always remembering that these substances must not come in contact with fire in any shape. "At housecleaning time," says Dr. Riley, "as many of the rooms should be bared at once as possible, and the housekeeper should go carefully over the rooms, removing all dust, and with a hand atomizer charged with benzine should puff the liquid into all the floor cracks and under the base-boards until every crevice has been reached. The carpets themselves, after thorough beating, should be slightly sprayed with 
the same substance, which will quickly evaporate, leaving no oder after a short time. The inflammability of benzine, however, should be remembered, and no light should be brought near it."

\section{The Bed Bug.}

Acanthia lectularia.

A short account of this notorious pest will be sufficient for the present purpose. Many people will recognize the peculiar flattened creatures represented at Fig. 142, as former acquaintances, and those who do not so recognize them are to be congratulated. The eggs of these insects are laid
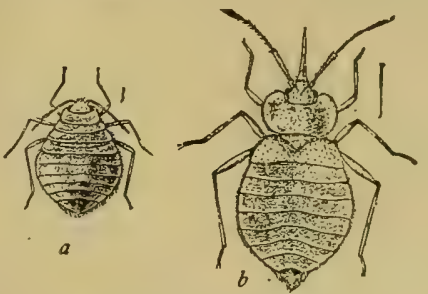

Fig. 142. Bed Bug: $a$, young; $b$, adult. Magnified. in the cracks of walls and bedsteads, and the young (a) do not differ essentially, except in size, from the adult $(b)$. Bed Bugs are able to exist a long time without food, and on the other hand, when food is abundant they multiply with remarkable rapidity.

Remedies.-Spraying the cracks of walls, beds, etc., where these insects occur with benzine is the best manner of destroying them. This substance kills the eggs as well as the adults. Great care, of course, should be taken to prevent their ingress to the house. 


\section{Clothes-moths.}

There are three closely related insects in the United States which may properly be called clothes-moths. They are quite similar in appearance, but the larvæ differ somewhat in feeding habits. The commonest one probably is the Case-making Clothes-moth (Tinea pellionella), the life-history of which Dr. Riley has thus summarized: "The small light-brown moths, distinguished by the darker spots at intervals on the wings, begins to appear in May and are occasionally seen flitting about as late as August. They pair and the female then searches for suitable places for the deposition of her eggs, working her way into dark corners and deep into the folds of garments, apparently choosing by instinct the least conspicuous places. From these eggs hatch the white, softbodied larvæ, each one of which begins immediately to make a case for itself from the fragments of the cloth upon which it feeds. The case is in the shape of a hollow roll or cylinder and the interior is lined with silk. As they grow they enlarge these cases by adding material to either end and by inserting gores down the sides which they slit open for the purpose. The larva reaches its full growth toward winter, and then, crawling into some yet more protected spot, remains there torpid through the winter within its case, which is at this time thickened and fastened at either end with silk. The transformation to pupa takes place within the case 
the following spring, and the moths soon aftermard issue. The larva feeds in all woolen cloths, and also in hair-cloth, furs and feathers."

Remedies.-Under this head we cannot do better than to quote the following remarks by Dr. Riley, who lately published an admirable series of articles, first in Good Housekeeping and afterwards in Insect Life, to which we are largely indebted for the information and illustrations on this subject: He says: "During the latter part of May or early in June a vigorous campaign should be entered upon. All carpets, clothes, cloth-covered furniture, furs and rugs should be thoroughly shaken and aired, and, if possible, exposed to the sunlight as long as practicable. If the house is badly infested, or if any particular article is supposed to be badly infested, a free use of benzine, in the manner mentioned in my last article, will be advisable. All floor cracks and dark closets should be sprayed with this substance. Too much pains cannot be taken to destroy every moth and every egg and every newly-hatched larva, for immunity for the rest of the year depends largely-almost entirelyupon the thoroughness with which the work of extermination is carried on at this time. The benzine spray will kill the insect in every stage, and it is one of the ferw substances which will destroy the egg. I would however, repeat the caution as to its inflammability. No light should be brought into a room in which it has been used until after a thorough airing and until the odor is almost dissipated. 
"The proper packing away of furs and winter clothing through the summer is a serious matter. A great deal of unnecessary expenditure in the way of cedar chests and cedar wardrobes and various compounds in the way of powders has been urged by writers on these pests. But experience fully proves that after a thorough treatment in May or June, garments, may be safely put away for the rest of the season with no other protection than wrapping them closely in stout paper, to preclude infection through some belated female. My assistant, Mr. L. O. Howard, tells me of an excellent plan which he has adopted. He buys for a small sum from his tailor a number of pasteboard boxes in which they deliver suits, and his wife carefully folds and packs away all clothing, gumming a strip of wrapping paper around the edges of the cover so as to leave no crack. These boxes will last for a life-time with careful use. Others use for the same purpose ordinary paper flour sacks or linen pillow-cases, which answer well. The success of these means depends entirely on the thoroughness of the preliminary work. Camphor, tobacco, naphthaline, and other strong odorants are only partial repellants and without the precaution urged are of little avail.

"Cloth-covered furniture which is in constant use will not be harmed, and the same may be said of cloth-lined carriages. Where such furniture is stored away or kept unused in a dark room, or where the carriages are left in a dark coach-house through the 
summer, at least two sprayings with benzine, say once in June and once about August first, will be advisable. Another plan which will act as a protection in such cases is to sponge the cloth linings and covers both sides where possible, with a dilute solution of corrosive sublimate in alcohol, made just strong enough not to leave a white mark on a black feather."

\section{Ants.}

Ants frequently become one of the most annoying kinds of household pests by getting into, and rumning over everthing. The species most generally troublesome is the Little Red Ant (Monomorium pharaonis,) which is world in its distribution-although it is said to have been originally a native of Europe.

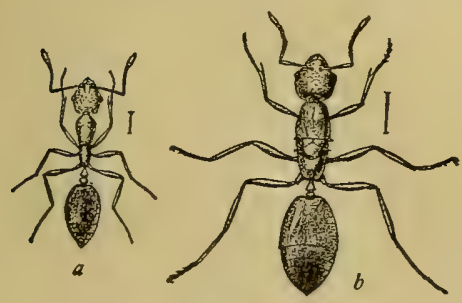

Fig. 143. Little Red Ant: $\alpha$, female ; The worker of this ubiquitous pest is represented at Fig. 143, $a$; and the female at $b$, of the same figure. The nests are made in almost an y concealed position about the house-under floors, behind base-boards, between walls, or in the walks or grass about the house. From these nests the foraging parties sally forth and over-run the house, devouring or carrying, off particles of food of all descriptions, getting into everything in sight, and often becoming an intolerable nuisance. 
Remedies.-The first essential to a successful fight with these insects, is to find the location of the nests. If they can then be reached it is easy to destroy them by means of benzine, gasoline, bisulphide of carbon, or even hot water-anything in fact, that will kill them. If any inflamable, or explosive substances are used, of course great care must be taken to keep away fire in any form.

There are certain larger ants that are frequently troublesome on lawns, by making their nests above the surface of the grass, and thus disfiguring them. A simple way of destroying these is recorded by Dr. Riley, as follows: A number of holes are punched in the nest by means of a pointed stick; a teaspoonful of bisulphide of carbon is then poured down each hole, and a damp blanket is thrown over the nest for a few minutes-then the blanket being removed the bisulphide is exploded at the mouth of each hole by means of a light at the end of a pole. The slight explosions drive the poisonous fumes down through the underground tunnels, killing off the ants in enormous numbers.

The Little Red Ants may be trapped by means of small sponges, saturated with sweetened water, and then occasionally dropped into boiling water. But this is a much less satisfactory method than that of destroying them in their nests. 


\section{IN DEX.}

Abbot sphinx, 121

Acanthia lectularia, 271

Achemon Sphinx, 119.

Acridium americanum, 213.

Aegeria pictipes, 58 .

" polistiformis, 108.

“" pyri, 65.

" rubi, 103.

“ tipuliformis, 96 .

" cucurbitæ, 176.

Agrotis saucia, 198.

Agrilus ruficolis, 107.

American cockroach, 267.

" locust, 248.

Anarsia lineatella, 87.

Anasa tristis, 178.

Anisota rubieunda, 140 .

Anisoptery x pometaria, 39.

" vernata, 41.

Anthonomus musculus, 95 .

" quadrigibbus, 54.

Anthomyia brassicæ, 188.

ceparum, 203.
Anthrenus scrophulariæ, 269.

Ants, 21, 275.

Apatela occidentalis, 59 .

Aphides, 158.

Aphis, apple, 38.

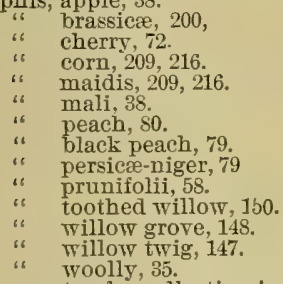

A pparatus for collecting insects, 22.

Apple, insects affecting, 29,56 .

\begin{tabular}{|c|c|}
\hline ॥ & aphis, 38 . \\
\hline " & curculio, 54 . \\
\hline a & leaf-roller, lesser, 42. \\
\hline 6 & leaf-skeletonizer, 49 . \\
\hline "6 & $\begin{array}{l}\text { maggot, } 02 \text {. } \\
\text { worm, } 51 \text {. }\end{array}$ \\
\hline ॥ & tree borer, flat-headed, 32 . \\
\hline " & round-heade \\
\hline & $\begin{array}{l}\text { caterpillar, yellow-n } \\
\text { tent caterpillar, } 42 \text {. }\end{array}$ \\
\hline
\end{tabular}

Applying insecticides, 21

A rmy worm, 14, 16.

Arsenic, white, 18.

Asparagus beetle, 204.
Bacterial diseases of insects, 16 .

Bag-worm, 138.

Bark-louse, oyster-shell, 33.

" " scurfy, 66.

Bean Weevil, 185̃.

Bed Bug, 271.

Benzine, 21

Beautiful wood nymph, 125

Bisulphide of carbon, 21.

Bird grasshopper, 248.

Biting insects, 13.

Blackberry, insects affecting, 103, 107. gall-fly, 107

Blissus leucopterus, 222

Blister beetle, black, 173 .

Blue jay, 143.

Boll worm, 218 .

Books about insects, 26.

Box-elder bug, 145 .

Breeding cages, 24.

Broad-necked Prionus, 127.

Bruchus obsoletus, 185. pisi, 186.

Buffalo tree-hopper, 36 .

“ carpet beetle, 269.

Buhach, 19.

Cabbage, insects affecting, 188.

"6 aphis, 200.

" butterfly, Southern, 191.

" maggot, 188.

" worm, imported, 190

" Plusia, 193.

" flea-beetle, 196.

" cut-worms, 197

" bug, Harlequin, 199

Cabbage worm, 20.

Cacocia cerasivorana, 75 .

Calandra granaria, 232.

Canker worm, 39.

" "6 fall, 39 .

Carbolic acid, 20 .

" fall, 39.

Carbon bisulphide, 21.

Carpet beetle, 269.

Carpocapsa pomonella, 51 .

Caterpillar hunters, 14.

Catocala ultronea, 59.

Cattle lice, 261.

Cecidomria grossularia, 102. " destructor, 220

" leguminicola, 237.

tritici, 231.

Cecropia emperor-moth, 131.

Celery caterpillar, 9, 175 .

Ceramica picta, 194.

Ceresa bubalus, 36 . 
Cherry, insects affecting, 72 .

$$
\text { " aphis, } 72 \text {. }
$$

Chinch bug, 12, 13, 16, 20, 21, 222 .

Chionaspis furfurus, 66 .

Chrysobothris femorata, 32.

Clisiocampa americana, 42.

Clothes-moths, 272.

" " Case-making, 272

$$
\begin{aligned}
& \text { " hay-worm, } 240 . \\
& \text { " leaf-beetle, } 235 . \\
& \text { " root-borer, } 234 \text {. } \\
& \text { "s seed-midge, } 237 . \\
& \text { " stem-borer, } 239 .
\end{aligned}
$$

Cockroaches, 267.

Coal tar, 21.

Coccotorus prunicida, 62 .

Codling moth, 51,70 .

Collecting insects, 22 .

$$
\text { " net, } 22 \text {. }
$$

Colorado potato beetle, 13, 169 .

Complete transformations, 12.

Compsomyia macellaria, 247.

Conotrachelus nenuphar, 60, 67, 80 .

Contagious diseases of insects, 16 .

Corn, insects affecting, 209.

$$
\text { "i aphis, } 215 .
$$

" root aphis, 209

"s "worm, southern, 212,

"stalk-borer, 214.

" web-worm, 215.

" worm, 218.

Craponius inæequalis, 128.

Crepidodera cucumeris, 177.

Crioceris asparagi, 204

Croton-bug, 267.

Cucumber, insects affecting, 176. ". flea-beetle, 177.

$$
\text { " beetle, striped, } 179 .
$$

Currant, insects affecting, 96, 102

$$
\begin{aligned}
& \text { " aphis, 100. } \\
& \text { " } \quad \text { bark-1ouse, 102. } \\
& \text { " borer. American, } 102 . \\
& \text { " } \text { " import 102. } \\
& \text { " fruit-worm, 102. } \\
& \text { " leaf-hopper, } 99 . \\
& \text { " span-worm, 102. } \\
& \text { " worm, imported, } 97 . \\
& \text { Cut worms, 14, 16. } \\
& \text { Cyanide bottle, 23. }
\end{aligned}
$$

Dactylopius adonidum, 160. destructor, 160.

Dakruma convolutella, 101.

Dalmatian insect powder, 19.

Darapsa myron, 121.

Datana angusii, 142

"s ministra 46

Desmia maculalis, 124

Diabrotica vittata, 179
Diabrotica punctata, 182, 212

Diastrophus nebulosus, 107.

Dicerca divaricata, 72.

Diseases of insects, 16

Disippus butterfly, 59 .

Domestic animals, insects affecting 257

Doryphora 10-lineata, 169.

Dragon-flies, 14.

Elateridæ, 213.

Elm leaf-beetle, imported, 136.

Emphytus maculatus, 92.

Empoa albopicta, 99.

Emulsion, kerosene, 20.

Enemies of injurious insects, 13.

Entomophthora, 17.

Epicærus imbricatus, 173.

Epicauta pennsylvanica, 173 .

$$
\text { " vittata, } 171 .
$$

Epochra canadensis, 102.

Eudemis botrana, 126.

Eudryas grata, 125.

Eufitchia rebearia, 102.

Eupithecia interruptofasciata, 102.

Eurycreon rantalis, 215.

External irritants, 17 .

Fall web-worm, 135 .

Flat-headed apple-tree borer, $32,63,70$, 81.

Flat-headed cherry-tree borer, $72,81$.

Flea-like negro-bug, 107.

Flowers, insects affecting, 158 .

Four-striped plant-bug, 102.

Fungous diseases of insects, 16.

Galeruca xanthomelæna, 136.

Garden Web-worm, 215 .

Gasoline, 21

German cockroach, 267.

Gooseberry, insects affecting, 96, 102.

$$
\text { " fruit-worm, 101. }
$$

Gortyna nitela, 214

Grain aphis, 227.

$$
\text { "s weevil, } 232 .
$$

Grape, insects affecting, 108, 127.

" berry moth, 126 .

" caterpillar, 15.

" curculio, 128

" phylloxera, 21, 109.

" root-borer, 108

" seed maggot, 128.

" sphinx moths, 119

"s vine beetle, spotted, 117

" " flea-beetle, 63, 114

" " leaf-hopper, 122.

" " leaf-roller, 124.

" " sphinx, green, 121.

Graphops pubescens, 85.

Graptodera chalybea, 114.

Grass, insects affecting, 242

Grasshoppers, 247.

$$
\text { ": } \quad \text { bird, } 248 .
$$


Grasshoppers red-legged, 249.

Gray dagger-moth, 59.

Green-striped maple worm, 140.

Hæmatopinus eurysternus, 262.

$$
\text { " } \quad \text { vituli, 263. }
$$

Hæmatobia serrata, 264.

Harlequin cabbage-bug, 199.

Heliothis armigera, 218.

Hellebore, 19, 22

Hessian fly, 220 .

Horn fiy, 264

Horse-louse, sucking, 266.

$$
\text { " biting, } 266 \text {. }
$$

Horned span-worm, 59 .

Hyphantria cunea, 135.

Hylastes trifolii, 234.

Imbricated snout-beetle, 173 .

Imported cabbage worm, 16, 19.

$$
\text { " currant-borer, 96. } 9 .
$$

Incomplete transformations, 12.

Insect powder, 19.

Insects, books about, 26 .

" collecting and preserving, 22.

Insects, diseases of, 16 .

$$
\begin{aligned}
& \text { " } \quad \text { parasitic, 15. } \\
& \text { " pins for, 24. } \\
& \text { " predaceous, 14. } \\
& \text { rearing, 24. }
\end{aligned}
$$

Insecticides, applying, 21.

Internal poisons, 17 .

$$
\text { the principal, } 17 .
$$

Introduction, 9.

Isosoma vitis, 128.

$$
\begin{aligned}
& \text { " hordei, } 230 . \\
& \text { " } \quad \text { gritici, } 230 . \\
& \text { grande, } 230 .
\end{aligned}
$$

Ithycerus noveboracensis, 81.

June bug, 74:

Kerosene, 20.

Kerosene emulsion, 20 .

Lachnosterna fusca; 74

Lachnus dentatus, 150.

"strobi, 151.

Lady-beetle, 14 .

Languria mozardi, 239.

Leaf-crumpler, 47.

Leaf-roller, lesser apple, 42.

"6

" " strawberry, 89.

Leaf-skeletonizer, apple, 49

Lecanium persicæ, 81.

$$
\begin{array}{ll}
\text { "6 pyri, } 70 . \\
\text { ribis, } 102 .
\end{array}
$$

Leptocoris trivittatus, 145.

Lesser apple leaf-roller, 44.

Limenitis disippus, 59 .

Little red ant, 275.

Lixus concavus, 183.

London purple, 18, 22.

Lygus pratensis, 93.

Macrodactylus subspinosus, 115

Maple bark-Iouse, 127, 143.

May beetle, 74 .

Maple worm, green-striped, 140.

Meadow maggot, 243.

Mealy bugs, 160.

Melanoplus femur-rubrum, 249.

spretus, 248.

Melanoxanthus, 147

$$
\begin{array}{ll}
\text { " } & \text { salicis, } 147 . \\
\text { s5.licti, 148. }
\end{array}
$$

Meromyza americana, 229 .

Moncomorium pharaonis, 275.

Murgantia histrionica, 199.

Mrtilaspis pomorum, 33 .

Myzus cerasi, 72.

$$
\text { " persica, } 79 \text {. }
$$

"s ribis, 100 .

Natural enemies of injurious insects, 13.

Nematocampa filamentaria, 59 .

Nematus ventricosus, 97.

New York weevil, 81.

Oberea bimaculata, 105.

Oecanthus niveus, 106.

Oestrus bovis, 259 .

Onion, insects affecting, 203

" maggot, 203.

Oriental cockroach, 267.

Orgyia leucostigma, 133.

Oyster-shell bark-Iouse, 33,70

Ox warble fly, 259.

Ox-louse, long-nosed, 263.

$$
\text { " bitiug, 263. } 262 .
$$

Pandorus sphinx, 121.

Papilio asterias, $11,175$.

Parasitic insects, 15.

Paria aterrima, 85.

Paris green, 17, 22.

Pea-weevil, 186.

Peach, insects affecting, 77,81 .

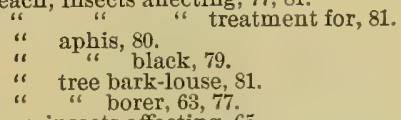

Pear, insects affecting, 65 .

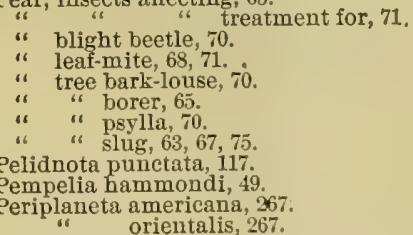


Persian insect powder, 19.

Philampelus achemon, 119. pandorus, 121.

Phlegethontius celeus, 165.

Phoxopteris comptana, 89.

Phycis indigenella, 47.

Phyllotreta vittata, 196.

Phyllodromia germanica, 267.

Phylloxera vastatrix, 111.

Phytonomus punctatus, 235.

Phytoptus pyri, 68, 71.

Pieris rapæe, 190.

" oleracea, 191

" protodice, 191.

Plant-lice, 158.

Platysamia cecropia, 131.

Plum, insects affecting, 58, 63.

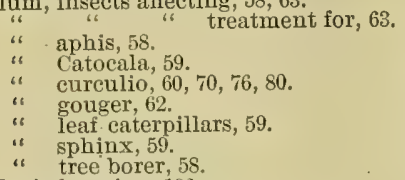

Pluisia

Poecilocapsus lineatus, 102

Polyphemus moth, 59 .

Potato stalk-weevil, 168.

"6 beetle, Colorado, 169 .

"s insects aftecting, 168.

Predaceous insects, 14 .

Preserving " 24.

Primary parasites, 16.

Principal insecticides, the, 17.

Prionus, broad-necked, 127 laticollis, 127.

Psenocerus supernotatus, 102.

Psylla pyri, 70.

Psyllobora twenty-maculata, 217.

Pulvinaria innumerabilis, 143

Pyrethrum, 19.

Raspberry, insects affecting, 103, 107.

" $\quad$ root-borer, 103.
" root gall-fly, 107.
"slug, 104.

" span-worm, 107.

Red-headed woodpecker, 143.

Red-necked Agrilus, 107.

Red-shouldered Sinoxylon, 127.

Red spider, 159.

Rhodites radicum, 107.

Rhubarb curculio, 183.

Robber-flies, 14.

Rocky Mountain locust, 21.

Rose, insects affecting, 154.

"“ beetle, 116 .

" bug, 116

" chafer, 115.

" leaf-hopper, 156.

" slug, 154.

Rosy Dryocampa, 141

Round-headed apple-tree borer, 29, 70 .

Sannina exitiosa, 77 .
Saperda candida, 29.

Scale-lice, 161.

Scelodonta nebulosus, 85 .

Schizoneura lanigera, 35.

Screw worm, 257.

Scurfy bark-louse, 66 .

Secondary parasites, 16

Selandria cerasi, 67,75 .

$$
\text { " rubi, } 104 .
$$

Setting boards, 25 .

Shade trees, insects affecting, 131

Sinoxylon basilare, 127.

Siphonophora avenæ, 227.

Skeletonizer, apple leaf, 49

Snowy tree cricket, 106.

Sphinx drupiferarum, 59

Spotted grape vine beetle, 117.

is willow-twig aphis, 147.

Spraying machines, 22 .

Squash, insects affecting, 176.

"* vine-borer, 176 .

i. bug, 178 .

Strawberry, insects affecting, 85, 94.

$$
\text { " " }
$$

" crown-borer, 87

" crown-miner, 87.

" leaf-roller, 89 .

" root-worms, 85 .

" slug, 92

" thrips, 95

" weevil, 95.

Striped cucumber-beetle, 179. harvest-spider.

Sucking insects, 13.

Tar, coal, 21

Tarnished plant bug, 9

Telea polyphemus, 59 .

Tent caterpillar, apple-tree, 42 .

Teras minuta, 44 .

Tetranychus telarius, 159.

Thrips tritici, 95.

Thyreus abbotii, 121.

Thyridopteryx ephemeræformis, 138.

Tile-horned Prionus, 127.

Tinea pellionella, 272 .

Tipula bicarnea, 243

Tobacco, 21.

Tobacco worm, 15.

Tomato worm, 15,165 .

Toothed willow aphis, 150.

Transformations of insects, 9, 12.

Tree-hopper, Buffalo, 36.

Trichobaris trinotata, 168

Trichodectes scalaris, 263. " pilosus, 266 " palumpilosus, 266.

Trypeta pomonella, 52 .

Twenty-spotted lady-beetle, 217

Tyloderma fragariæ, 87.

Typhlocyba rosæ, 156 . vitis, 122

Variegated cut-worm, 198.

Veratrum album, 19. 


\section{INDEX.}

Walnut caterpillar, 142.

Wheat, insects affecting, 220.

" bulb-worm, 229 .

" joint-worms, 230 .

“ miage, 231.

White arsenic, 18.

White grub, 20.

White hellebore, 19.

White-marked tussock-moth, 133.

White pine aphis, 151.

Willow aphis, toothed, 150.

Willow-grove aphis, 148 .
Willow-twig aphis, 147.

Wireworms, 213.

Woodpecker, red-headed, 143.

Woolly aphis, 35 .

Woolly maple bark-louse, 143.

Xyleborus pyri, 70 .

Yellow-necked apple-tree caterpillar $46,143$.

Zebra caterpillar, 194.

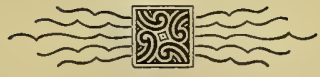




\section{ERRATA.}

Page 16. Third line from bottom: for sowewhat read somewhat. Under Fig. 6: for Entomophora read Entomophthora.

Page 17. Seventh line from top: for Entomophora read Entomophthora.

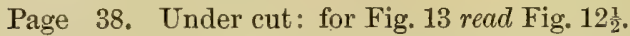

Page 122. Third line from bottom: for Typlocyba read Typhlocyba.

Page 158. Under cut: for Fig. 83 read Fig. 84. Sixth line from bottom : for Fig. 83 read Fig. 84.

Page 260. Top line : omit "as shown at d."

" Second line from top: for e read $b$.

" Fourth line from top: for a read $c$. 


\section{APPENDIX.}

ADVERTISEMENTS

OF

INSECTICIDE MACHINERY

AND

INSECTICIDES. 
When farmers cease to pay a tax of from 10 to 50 per cent. to insects they will not have cause to worry so much about their tax to the State.-Correspondent, Ohio Farmer.

\section{WE HAVE \\ "CAPPED THE CLIMAX,"}

and our spraying outfits are conceded to be the acme of perfection. Our spraying apparatus and our spraying outheds of the farmer, fruit grower and vineyardist for a means to check the ravages of insects to fruits and prevent fungoid diseases of grapes. To attain this end we have invested in a large plant for the manufacture of spraying apparatus, and have spent years and money experimenting and improving our machinery until, to-day,

\section{THE CLIMAX NOZZLES,}

\section{THE CLIMAX PUMPS}

Are Unrivaled and Unsurpassed in the following Points of Merit:

ECONOMICAL. PRACTICAL.

DURABLE.

EASY TO MANIPULATE.

THOROUGH IN WORK.

THE

"CLIMAX" TRIPOD PUMPS

AND THE NOW JUSTLY CELEBRATED

"CLIMAX" NOZZLES

ARE ALL COVERED BY PATENTS.

THE "CLIMAX" NOZZLE

IS THE

RECOGNIZED STANDARD

AMONG THE LEADING FRUIT AND

GRAPE GROWERS.

Copper and Ammonia solutions will use up an iron pump in a very short time; only brass or copper will stand it. $-H$.

Tanner \& Son, Medina, N. $Y$.

In all our pumps the barrel of the pump and plunger are brass; also the valves, which are not liable to get out of order,

IMPORTANT. as they are not affected by arsenical solutions, hot water or other preparations. A fine strainer is provided at the bottom of the suction pipe, which will prevent any obstructions from getting into the valves or nozzles.

(SEE NEXT PAGE.) 
The friend of the fruit and grape grower is the Nixon Orchara and Vineyard Cart with its "Climax" Nozzles. - Correspondent, Orchard and Garden.

\section{SOLID FACTS.}

\section{GRAPE AND FRUIT GROWHRS,}

Stop just one minute and think how many millions of dollars are lost annually by the ravages of insects and fungus diseases of grapes. These losses are so great that the government is now spending large sums of money, in annual appropriations to Experiment Stations, to discover remedies to check this devastation. "Spraying" is the recommended remedy.

\section{OUR ORCHARD AND VINEYARD CART.}

THIS CUT REPRE-

SENTS OUR O. AND

V. CART WITH THE

SHAFTS DETACHED

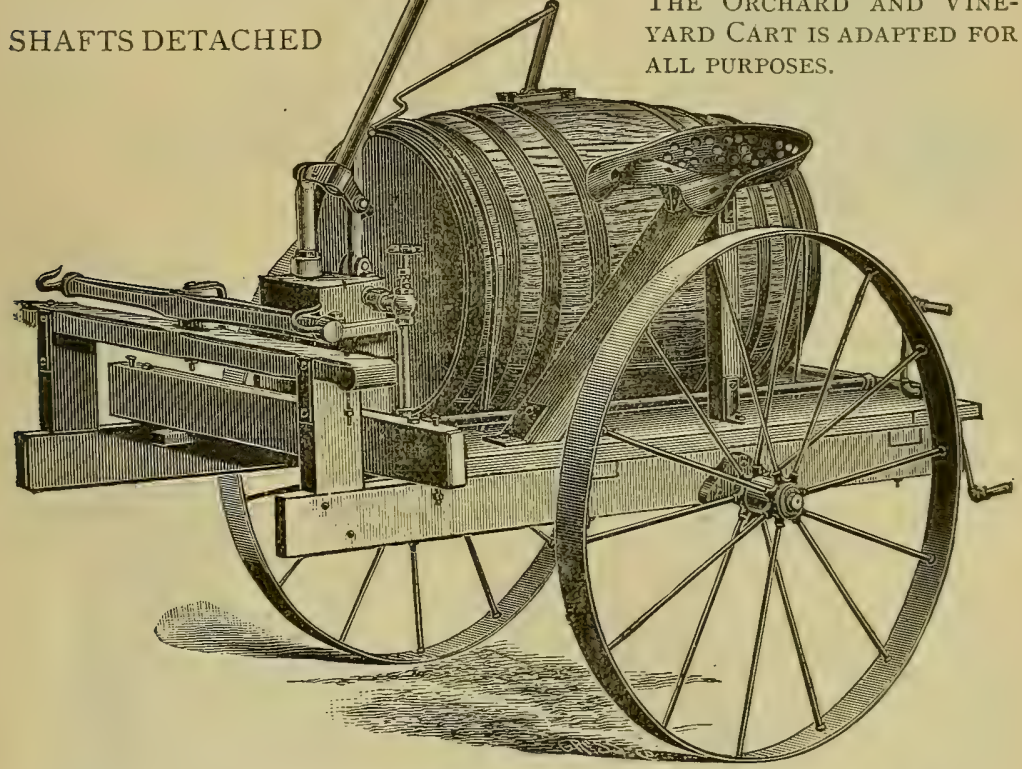

THE NIXON NOZZLE \& MACHINE CO.,

DAYTON, OHIO, U. S. A.
IT IS EOUIPPED WITH "Climax" Nozzles, which ARE ADJUSTABLE, SO THAT THE SPRAY MAY BE GIVEN ANY DESIRED DIRECTION. ThE ORCHARD AND VINEYARD CART IS ADAPTED FOR ALL PURPOSES. 


\section{Our Spraying Outfits are Cheapest and Best.}

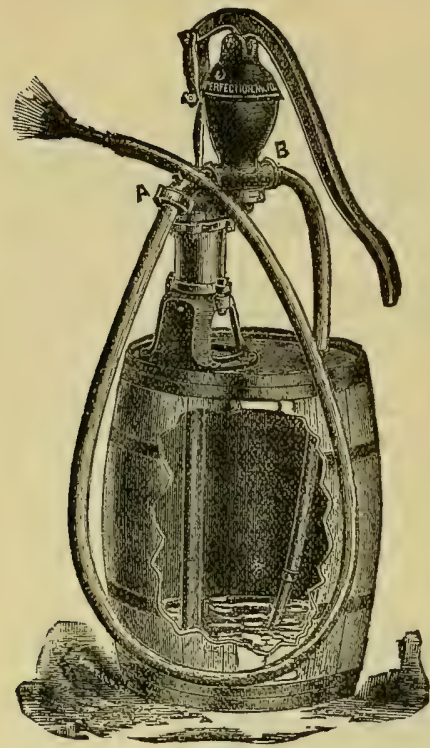

FIC. 45.

\section{The Perfection Out-fit.}

Stirs the liquid automatically, and will Spray 100 Trees Per Hour. Has Ten feet of discharge hose, and a GraduAting spray nozzle, and suction pipe ready to mount on a barrel. Can be fitted with brass cylinder, plunger and rod when so ordered.

Don't buy an inferior machine when you can get a "Perfection" at the same price.

We also manufacture the Victor Improved Horse Power Spraying Machine.

Especially adapted for spraying Vineyards and Orchards.

\section{Our Nera Knapsack Sprayer.}

For Vineyards, Nurseries, Fruit Orchards and Potato Fields.

This Machine consists of a copper reservoir, holding six gallons. The pump is made entirely of brass and copper, and can neither corrode nor rust. There is a large air chamber, as shown in the engraving, which will keep up the pressure and continue to discharge the spray for nearly one minute after the operator stops pumping. A brass pipe, fifteen inches in length, with a stop cock, is furnished with each machine. The nozzle is the celebrated "Vermorel" so highly recommended by Prof. Riley, and gives universal satisfaction. This machine is adapted for applying remedies in the treatment of black rot, mildew, and other diseases of the grape, as well as the treatment of leaf and potato blight.

A funnel for filling the tank is furnished with each outfit, in which is a fine Wire Strainer that permits no leaves or dirt to pass into the tank.

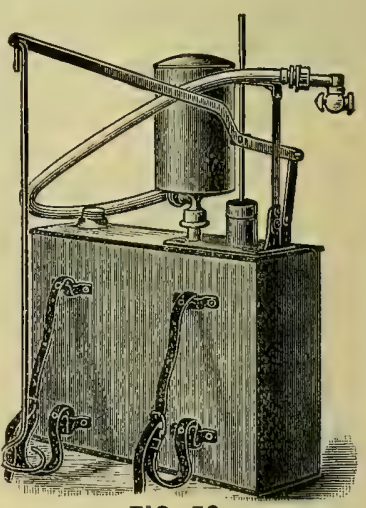

FIG. 50.

Our machines are Cuaranteed First class in Field Force Pump Co. WIIIIE FOR CIRCUIAIS. 


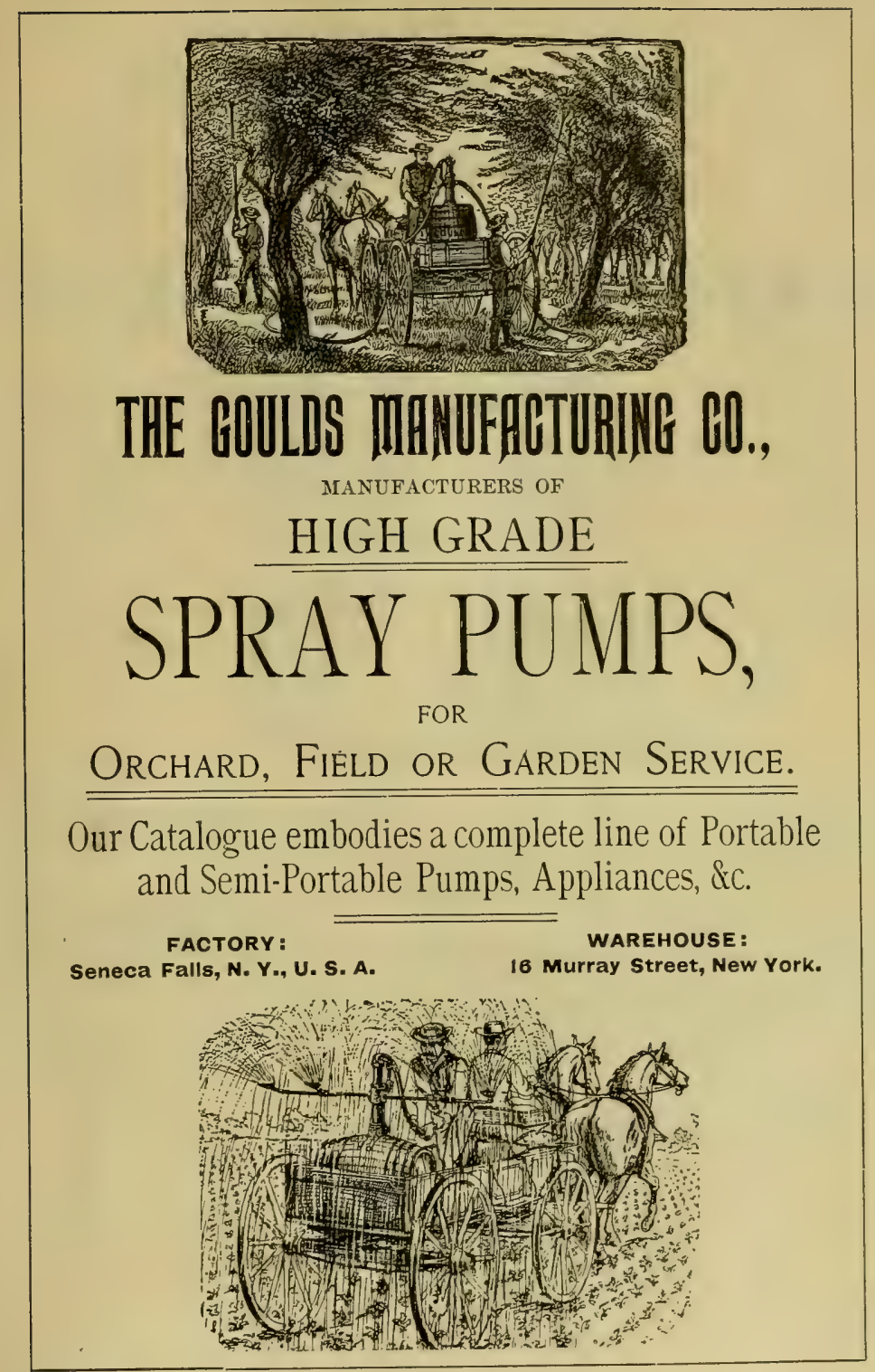




\section{The Excelsior Sprayer.}

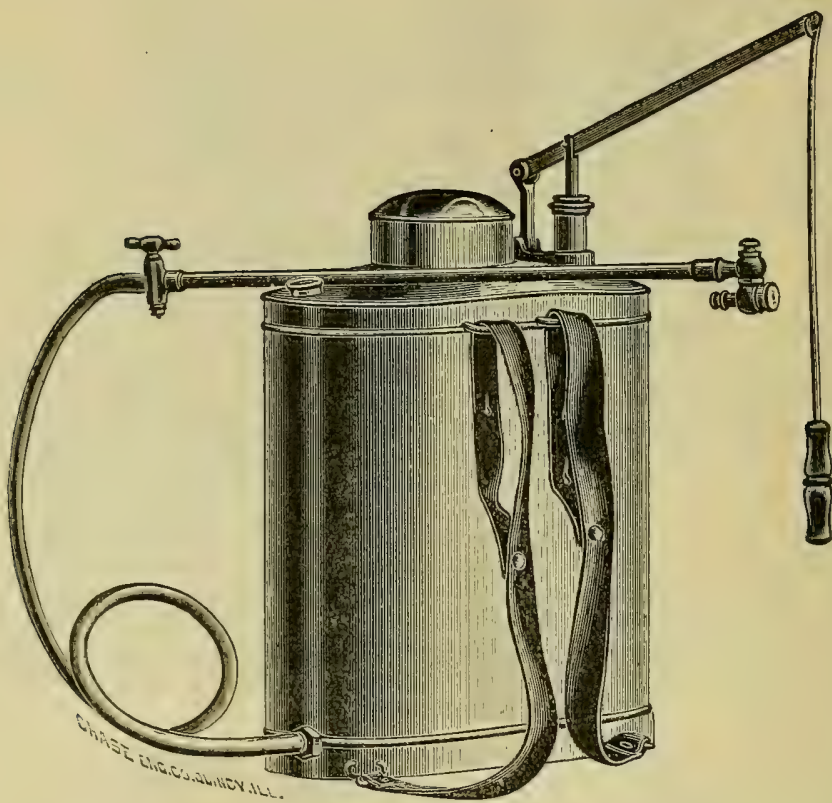

Spray your Frnit Trees \& Vines.

Wormy Fruit and Leaf Blight of Apples, Pears, Cherries, Plum Curculia prevented by spraying with the EXCELSIOR SPRAY PUMP. Grape and Potato Rot prevented by using EXCELSIOR KNAPSACK SPRAYER; also injurious insects which infest Currants, Gooseberries, Raspberries and Strawberries.

Perfect Fruit always Sells at Good Prices.

Catalogue showing all injurious insects to fruits mailed free.

Large stock of Fruit Trees, Vines and Berry Plants at Воттом Prices.

Address, WIM. STAHL, Quincy, Illinois. 


\section{J. C. Vineyard, Orchard and Potato SPRAYING MACHINES.}

Attention is called to the Two New Spraying Machines of the M. J. C. type.

\section{The m. J. G. Vineuarí \& Orcharí Spraying Magchine}

A thoroughly well-made, geared machine, brass throughout, adapted for both vineyard and orchard use. Dram by one horse, with seat in front of spray, and automatic agitator. Provided with a new nozzle that throws the spray wide or narrow, and distributes the solution over the whole surface, a thing no other nozzle will do. It throws a finer mist, and is less than one-tenth the trouble by way of clogging, as well as being a great deal more SIMPLE and DURABLE.

I ALSO MANUFACTURE THE

M. J. C.

Potato \& Orchard

Spraying Machine.

shown in the cut.

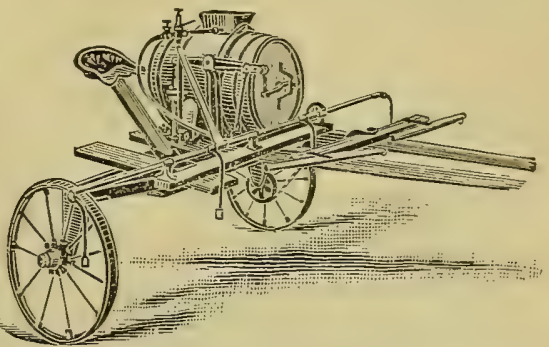

This machine has the same style nozzle and agitator, and is constructed on the same principles as the M. J. C. Vineyard and Orchard Machine-but it is operated with two horses and can not be used in vineyards. This machine is guaranteed to spray potatoes more thoroughly and with less trouble than any machine before the public.

\section{SEND FOR CIRCULARS.}

Address, M. J. C A S W E L L, Inventor and Sole Proprictor.

Postoffice address: Box 17, SAndusky, O. 


\section{SPRAY YOUR FRUIT TREES.}

\section{$\$ 17$ SPRAYING OUTFIT $\$ 5.50$}

Outfit Combines Three Complete Brass Machines.

\section{Will Thoroughly Spray a Ten-Acre Orchard Per Day.}

A VALUABLE ILLUSTRATED BOOK (WORTH \$5.00) ON "OUR INSECT FOES" GIVEN TO EACH PURCHASER. NIy agents are making from $\$ 5$ to $\$ 20$ per day. GOODS GUARANTEED AS REPRESENTED OR MONEY REFUNDED, Don't buy a spraying outfit until you receive my Mlustrated Catalogue, Price List and other valuable matter on spraying fruit trees and vines.

In the Annual Report of the Ohio Experiment Station for 1890 Prof. C. M. WeED says: "Queries frequently reach this Station concerning low priced spraying pumps for use in small orchards and about the home grounds. There are a number of such machines on the market. One of the most satisfactory ones which I have tried is manufactured by P. C. Lewis, Catskill, N. Y., the price of which, delivered express free, is $\$ 5.50$. I have used this pump more or less for several years and can conscientiously recommend it for the purposes stated above."

ADDRESS

\section{P. C. LEWIS, CATSKILL, N. Y.}




\section{SPRAYING}

\section{FRUIT \\ TREES.}

Prof. J. A. Lintner, State Entomologist, Albany, N. Y., says:

"The experience of the last few years has shown us that a very large proportion of our most destructive insect pests can be controlled by spraying some liquid insecticide by means of a suitable force pump. The best insecticide for use against fruit insects is undoubtedly Paris Green or London Purple. Of these two, I do not hesitate to recommend 'London Purple' in preference It is quite as effective, is less liable to burn the foliage; there is less danger from accidental poisoning from it, it is less expensive, and is held more easily in mixture with water."

\section{* * * *}

\section{$L O N D O N$}

\section{PURPLE}

Is used almost invariably by Farmers, Fruit Growers and others, for spraying to destroy the Codlin Moth, Canker Worm, Curculio, Elm Beetle, Potato Bug, and all Leaf Eating Caterpillars and Insects.

For circular of opinions, etc., address,

\section{HEMINGWAY'S}

\section{"LONDON PURPLE" GO., Limited, NEW YORK, N. Y.}




\section{Hammond's Slug Shot Works,}

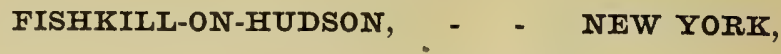

MANUFACTURE

\section{Insecticides and Fungicides.}

\section{SLUG SHOT KILLS BUGS.}

A cheap powder destructive to insects injurious to house and garden plants, shrubs, trees, vines, potatoes, melons, cabbage, currants, etc. Used in all latitudes since 1880 , with SAFETY to man, beast and fowl. Put up in perforated screw top canisters, five and ten pound packages, and bulk.

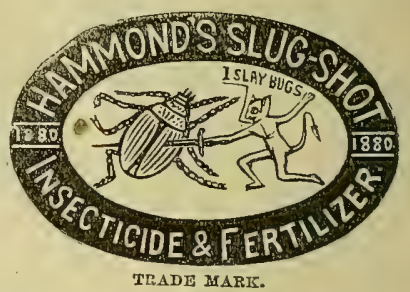

\section{THRIP JUICE KILLS LICE AND SCALE.}

A concentrated liquid insecticide for destroying the lice, scale, caterpillars, mealy bugs, etc. Nor-Poisonous diluted with one hundred times its bulk. Arseniated, for orchard use, dilute four hundred times its bulk with water. Put up in packages of from one-half pint to barrel.

\section{SCROFULARIA FOR CARPET BEETLES, ETC.}

A compound powder of the most effective character as a preventative of carpet beetle ravages, and the destruction of bugs, roaches, ants, etc.

\section{COPPER COMPOUND FOR ROT.}

A powder for use suspended in water, as a preventative of rot in grapes.

\section{GRAPE DUST FOR MILDEW.}

A thoroughly reliable powder for preventing mildew on roses, grapes, gooseberries, etc.

\section{AMERICAN SHEEP WASH.}

For killing all lice that prey on sheep, dogs, cats or cattle. Not surpassed by any preparation in the world.

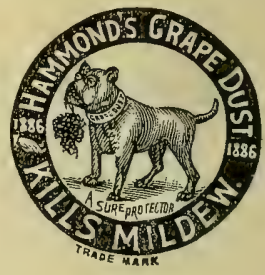

THESE PREPARATIONS ARE SOLD BY THE SEEDSMEN OF AMERICA. 






\section{LIBRARY OF CONGRESS \\ |||||||||||||||||||||||||||||||||||||||||| \\ ||||||||||||||||||||||||||||||||||||||||||||||||||||||}

00008880025 